\title{
ESTUDO DOS MOMENTOS FLETORES NEGATIVOS NOS APOIOS DE LAJES FORMADAS POR ELEMENTOS PRÉ- MOLDADOS TIPO NERVURAS COM ARMAÇÃO TRELIÇADA
}

\section{Eng. Fábio Lopes Magalhães}

\author{
Dissertação apresentada à Escola de Engenharia \\ de São Carlos da Universidade de São Paulo, \\ como parte dos requisitos para obtenção do título \\ de Mestre em Engenharia de Estruturas.
}

ORIENTADOR: Mounir Khalil El Debs

São Carlos

2001 
Ficha catalográfica preparada pela Seção de Tratamento da Informação do Serviço de Biblioteca - EESC/USP

188e Magalhães, Fábio Lopes

Estudo dos momentos fletores negativos nos apoios de lajes formadas por elementos pré-moldados tipo nervuras com armação treliçada / Fábio Lopes Magalhães. -- São Carlos, 2001.

Dissertação (Mestrado) -- Escola de Engenharia de São Carlos-Universidade de São Paulo, 2001.

Área: Engenharia de Estruturas.

Orientador: Prof. Dr. Mounir Khalil El Debs.

1. Laje pré-moldada. 2. Concreto armado.

3. Comportamento não-linear. 4. Rotações plásticas. 5. Análise experimental. 6. Redistribuição de esforços. I. Título. 
FOLHA DE APROVACÃO

Candidato: Engenheiro FÁBIO LOPES DE MAGALHÃES

Dissertação defendida e aprovada em 19-04-2001

pela Comissão Julgadora:

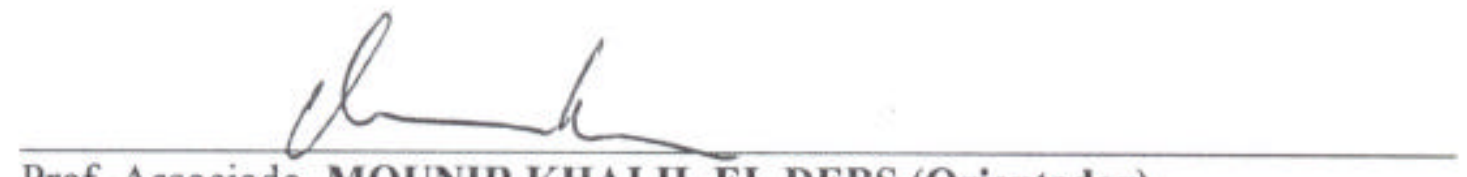

Prof. Associado MOUNIR KHALIL EL DEBS (Orientador)

(Escola de Engenharia de São Carlos - Universidade de São Paulo)

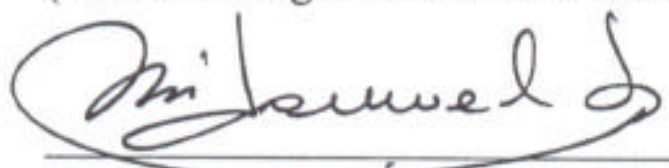

Prof. Doutor JOSÉ SAMUEL GIONGO

(Escola de Engenharia de São Carlos - Universidade de São Paulo)

$$
\text { Syduy ful au } h
$$

Prof. Doutor SYDNEY FURLAN JUNIOR

(UFSCar - Universidade Federal de São Carlos)

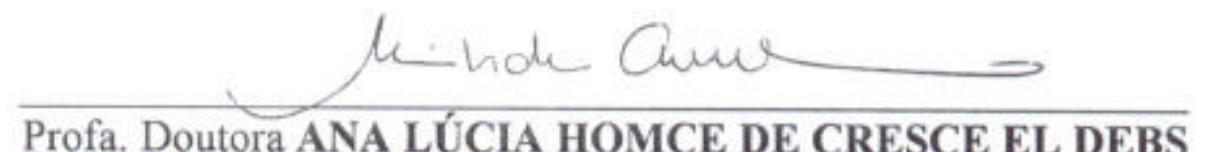

Coordenadora do Programa de Pós-Graduação em

Engenharia Civil (Engenharia de Estruturas)

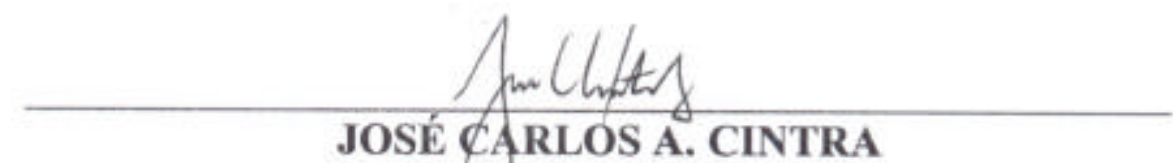

Presidente da Comisşão de Pós-Graduação da EESC 
A meus pais

Agamenon Magalhães e Diana Lopes 


\section{AGRADECIMENTOS}

A Deus que me deu força e sabedoria necessárias para a conclusão deste trabalho.

Ao professor Mounir Khalil El Debs pela dedicação, compreensão e orientação prestadas na elaboração deste trabalho.

Ao engenheiro Alonso Droppa Júnior pela ajuda prestada no desenvolvimento deste trabalho.

A meus pais a quem dedico este trabalho.

A meus irmãos Júnior, Carlos, Regina, Anderson e Vitor pelas palavras de incentivo.

À família Athayde, em especial a Andrea pela compreensão nos momentos em que estive ausente.

Aos amigos alagoanos Alexandre, Aline, Arthur, Jorginho, Júlio, Luciano, Marilene, Márcio, Patrick, Paula, Renata e Romel.

Aos amigos do curso de mestrado, em especial André, Andrea, Ewerton, Luciano, Luis Claudio, Luiz Paulo, Maluli, Ricardo, Robson, Rogério, Renê, Valentim e Valério pelo convívio neste período.

Aos técnicos do Laboratório de Estruturas Amauri, Jorge, Mário, Mauri, Valdir, João, Ricardo e ao engenheiro Luiz, os quais foram indispensáveis na parte experimental deste trabalho.

À bibliotecária Nadir e à secretária da pós-graduação Rosi.

Aos professores do Departamento de Engenharia Estrutural - EES da UFAL, em especial Dilze, Eduardo, Flávio e Severino que me incentivaram a iniciar a pós-graduação em estruturas.

Ao Programa Especial de Treinamento - PET da UFAL, em especial o professor Roberaldo Carvalho.

Aos demais colegas do Departamento de Estruturas da EESC/USP que indiretamente ajudaram para a conclusão deste trabalho.

A Armação Treliçada PUMA Ltda. pela doação de materiais e apoio financeiro necessários na experimentação. 
Às empresas Lajotec e Lajes Pinhal pela doação de vigotas pré-moldadas com armação treliçada necessárias na experimentação.

À Fundação de Amparo à Pesquisa do Estado de São Paulo - FAPESP, pelo auxílio financeiro através do projeto temático.

À Coordenadoria de Aperfeiçoamento de Pessoal de Nível Superior CAPES, pela bolsa de estudos concedida. 


\section{SUMÁRIO}

LISTA DE FIGURAS …............................................................. i

LISTA DE TABELAS .................................................................... ix

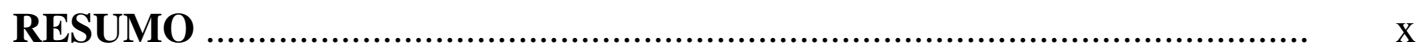

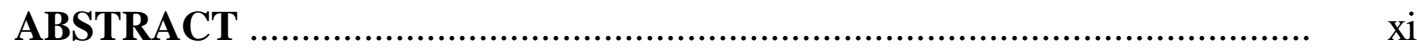

\section{CAPÍTULO 1: INTRODUÇÃO}

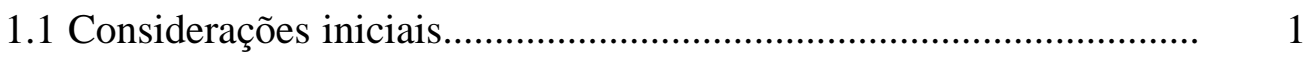

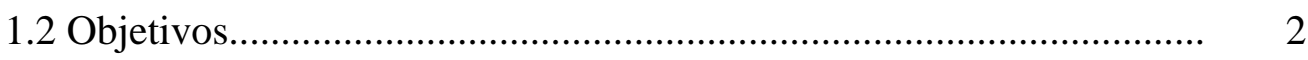

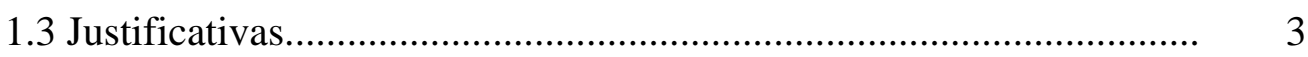

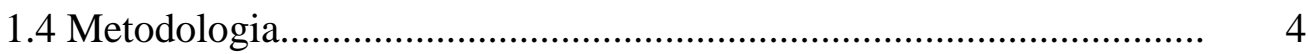

1.5 Apresentação do trabalho................................................................... 5

\section{CAPÍTULO 2: LAJES FORMADAS POR ELEMENTOS PRÉ-MOLDADOS}

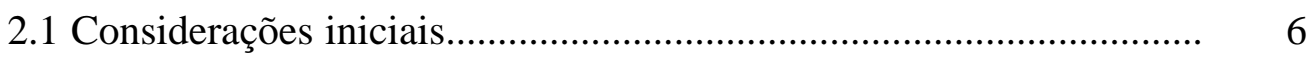

2.2 Lajes nervuradas formadas por vigotas pré-moldadas com armação treliçada................................................................................. 9

2.3 Análise estrutural de lajes nervuradas............................................... 14

2.4 Consideração da redistribuição dos esforços...................................... 21

2.4.1 Recomendações da norma brasileira NBR-6118 (1978)............ 22

2.4.2 Recomendações da norma espanhola EF-96 (1997)................. 22

2.4.3 Recomendações práticas para consideração da continuidade... 23

\section{CAPÍTULO 3: ANÁLISES TEÓRICAS}

3.1 Considerações iniciais..................................................................... 25

3.2 Fundamentos para a consideração da não-linearidade física do concreto. 26

3.2.1 O Diagrama momento x curvatura segundo o CEB-90 (1991)... 26

3.2.2 Carregamento incremental...................................................... 32

3.3 Comportamento de estruturas estaticamente indeterminadas em concreto armado 
3.4 Considerações sobre a capacidade de rotações plásticas..................... 36

3.5 Determinação da força última no modelo teórico ............................... 42

3.5.1 Critério da capacidade de rotação das rótulas plásticas............ 42

3.5.2 Critério da formação de um mecanismo de colapso................... 47

3.6 O programa propriamente dito....................................................... 48

\section{CAPÍTULO 4: PROGRAMA EXPERIMENTAL}

4.1 Considerações iniciais..................................................................... 51

4.2 Definições gerais dos modelos ensaiados......................................... 52

4.2.1 Definição das dimensões............................................................. 52

4.2.2 Definição da armadura de continuidade estrutural.................... $\quad 55$

4.3 Descrição dos ensaios..................................................................... 58

4.3.1 Execução das fôrmas................................................................ 58

4.3.2 Montagem, moldagem, adensamento e cura............................... 60

4.3.3 Estrutura de reação.....................................................................

4.3.4 Transporte dos modelos para posição de ensaio......................... 65

4.3.5 Instrumentação......................................................................... 68

4.3.6 Procedimentos de ensaio..............................................................

4.4 Caracterização mecânica dos materiais............................................... 74

4.4.1 Concreto.................................................................................. 74

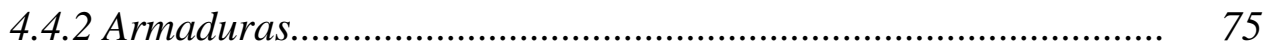

4.5 Resultados dos ensaios................................................................. 77

4.5.1 Procedimentos utilizados na elaboração dos resultados............. 77

4.5.2 Determinação dos momentos fletores experimentais.................. 80

4.5.3 Ensaio do modelo M15................................................................ 81

4.5.4 Ensaio do modelo M40............................................................... 85

4.5.5 Ensaio do modelo Mac............................................................... 90

\section{CAPÍTULO 5: ANÁLISE DE RESULTADOS}

5.1 Considerações iniciais.................................................................... 95

5.2 Comparações entre resultados experimentais.................................... 96

5.3 Idealizações feitas na modelagem numérica das faixas de lajes.......... 101 
5.4 Comparação entre resultados teóricos e experimentais....................... 103

5.4.1 Modelagem numérica do modelo M15..................................... 103

5.4.2 Modelagem numérica do modelo M40...................................... 105

5.4.3 Modelagem numérica do modelo Mac....................................... 108

5.5 Ajustes nos parâmetros do modelo teórico......................................... 111

5.6 Estimativa do comportamento do modelo M0.................................. 123

CAPÍTULO 6: CONSIDERAÇÕES FINAIS E CONCLUSÕES................. 128

\section{BIBLIOGRAFIA}

Referências bibliográficas.............................................................. 132

Bibliografia complementar............................................................. 134

\section{APÊNDICE}




\section{LISTA DE FIGURAS}

$\begin{array}{lll}\text { FIGURA 2.1 } & \text { Laje formada por nervuras pré-moldadas [EL DEBS (2000)] }\end{array}$

FIGURA 2.2 Vigotas pré-moldadas disponíveis no mercado brasileiro ..... 8

FIGURA 2.3 Seção da vigota com armadura em forma de treliça e perspectiva da armação treliçada .......................................... 10

FIGURA 2.4 Vigota com armação em forma de treliça ............................. 10

FIGURA 2.5 Largura efetiva da mesa de compressão ............................... 15

FIGURA 2.6 Dimensionamento da nervura - mesa comprimida e tracionada .................................................................... 16

FIGURA 2.7 $\quad$ Armadura de distribuição [Di PIETRO (1993)] .................... 20

FIGURA 2.8 Diagramas dos momentos de acordo com a norma espanhola EF-96 (1997) ........................................................ 23

FIGURA 2.9 Considerações práticas para redistribuição dos esforços ....... 24

FIGURA 3.1 Relação Momento x Curvatura segundo o CEB-90 (1991) ... 28

FIGURA 3.2 Diagrama tensão x deformação simplificado dos materiais $[$ NBR-6118(1978)] ...................................................... 31

FIGURA 3.3 Diagrama genérico de carga $\mathrm{x}$ deslocamento: 1) desenvolvimento real 2) desenvolvimento por etapas lineares [CARVALHO (1994)] ........................................ 32

FIGURA 3.4 Estrutura hiperestática unidirecional [CEB (1998)] .............. 33

FIGURA 3.5 Evolução dos momentos fletores nas seções críticas $\mathrm{x}$ carregamento aplicado [CEB (1998)] ................................. 34

FIGURA 3.6 Diagrama momento x rotação para as seções do meio do vão e apoio intermediário como função do grau de redistribuição. [CEB (1998)] ............................................... 36

FIGURA 3.7 Tipos de rótulas plásticas [CEB (1998)] …........................... 38

FIGURA 3.8 Determinação da curvatura média a partir dos deslocamentos ................................................................... 44

FIGURA 3.9 Viga equivalente na região do apoio central .......................... 44 
FIGURA 3.10 Capacidade de rotação plástica como função da linha neutra [CEB-90(1991)] ........................................................ 46

FIGURA 3.12 Elemento BEAM4-3D Elastic Beam [ANSYS ${ }^{\circledR}$ ] ............. 49

FIGURA 3.13 Fluxograma para análise não-linear utilizando o programa ANSYS $^{\circledR}$......................................................... 50

FIGURA 4.1 Planta de fôrma do elemento estrutural - dimensões em cm . 53

FIGURA 4.2 Corte longitudinal do elemento estrutural - dimensões em $\mathrm{cm}$

FIGURA 4.3 Seção transversal dos elementos estruturais- dimensões em $\mathrm{cm}$

FIGURA 4.4 Esquema geral da vigota - dimensões em $\mathrm{cm}$...................... 54

FIGURA 4.5 Nervura transversal .......................................................... 55

FIGURA 4.6 Viga de apoio ............................................................ 55

FIGURA 4.7 Ações utilizadas no dimensionamento ................................. 56

FIGURA 4.8 Vista superior das fôrmas .................................................... 59

FIGURA 4.9 Corte longitudinal das fôrmas ................................................ 59

FIGURA 4.10 Vista geral das fôrmas ........................................................... 60

FIGURA 4.11 Detalhes da fôrma dos modelos .............................................. 60

FIGURA 4.12 Posicionamento das vigotas pré-moldadas ........................... 61

FIGURA 4.13 Colocação dos elementos de enchimento e fixação das nervuras transversais ........................................................ 61

FIGURA 4.14 Fixação da armadura de distribuição ................................... 61

FIGURA 4.15 Fixação da armadura negativa ............................................. 62

FIGURA 4.16 Lançamento e adensamento do concreto ............................... 62

FIGURA 4.17 Improvisação do escoramento dos blocos de EPS no dia da concretagem ….............................................................. 63

FIGURA 4.18 Estrutura de reação .............................................................. 64

FIGURA 4.19 Esquema geral para içamento e transporte das faixas de lajes - dimensões em cm ................................................. 65

FIGURA 4.20 Estrutura pronta para ser içada ............................................. 66

FIGURA 4.21 Detalhes da ligação das lajes com a estrutura de içamento ... 66

FIGURA 4.22 Içamento e colocação da estrutura na posição de ensaio ....... 67 
FIGURA 4.23 Detalhe da fixação da cinta ao perfil metálico ...................... 67

FIGURA 4.24 Transdutores de deslocamentos ........................................... 68

FIGURA 4.25 Transdutores de deslocamentos e células de carga na região do apoio central ............................................................. 69

FIGURA 4.26 Atuadores hidráulicos e células de carga .............................. 69

FIGURA 4.27 Transdutores de deslocamento, atuadores hidráulicos e células de carga - estrutura em carga ............................... $\quad 70$

FIGURA 4.28 Posicionamento dos extensômetros nas faixas de lajes ......... 70

FIGURA 4.29 Instrumentação da armadura da vigota pré-moldada no ponto de máximo momento fletor positivo ........................... 71

FIGURA 4.30 Panorama da instrumentação da armadura negativa modelo M15 …............................................................. 71

FIGURA 4.31 Distribuição da força do atuador hidráulico no vão do elemento estrutural ............................................................. 73

FIGURA 4.32 Moldagem dos corpos-de-prova …........................................ 74

FIGURA 4.33 Preparação do corpo-de-prova de concreto para ensaio de determinação de módulo de elasticidade .............................. $\quad 75$

FIGURA 4.34 Diagrama tensão x deformação das barras com 4,2mm de diâmetro

FIGURA 4.35 Diagrama tensão x deformação das barras com 6,0mm de diâmetro

FIGURA 4.36 Forças atuantes nas faixas de lajes .......................................

FIGURA 4.37 Evolução dos momentos fletores ao longo do eixo longitudinal do modelo .................................................... 78

FIGURA 4.38 Deslocamentos nas seções dos modelos ............................... 78

FIGURA 4.39 Deformações nas seções dos modelos .................................. 79

FIGURA 4.40 Cálculo dos momentos fletores experimentais ..................... 80

FIGURA 4.41 Valores de momentos fletores obtidos a partir da aquisição dos dados de ensaio

FIGURA 4.42 Evolução dos máximos momentos fletores positivo e negativo - M15 
FIGURA 4.43 Evolução dos momentos fletores experimentais- modelo M15

FIGURA 4.44 Deslocamentos experimentais - M15 .

FIGURA 4.45 Deformações na armadura negativa obtidas no ensaio - M15

FIGURA 4.46 Deformações no concreto comprimido obtidas no ensaio M15

FIGURA 4.47 Fissuração devido ao momento fletor negativo - modelo M15

FIGURA 4.48 Deformações na armadura negativa ao longo do seu eixo M15

FIGURA 4.49 Evolução dos máximos momentos fletores positivo e negativo - M40

FIGURA 4.50 Evolução dos momentos fletores de ensaio - modelo M40 ... 86

FIGURA 4.51 Deslocamentos experimentais - M40 ................................. 87

FIGURA 4.52 Deformação da armadura negativa obtidas no ensaio - M40

FIGURA 4.53 Deformações no concreto comprimido obtidas no ensaio M40

FIGURA 4.54 Fissuração devido atuação do momento fletor negativo modelo M40

FIGURA 4.55 Evolução da abertura de fissuras sobre o apoio central modelo M40

FIGURA 4.56 Deformações na armadura negativa ao longo do seu eixo M40

FIGURA 4.57 Evolução dos máximos momentos fletores positivo e negativo - modelo Mac

FIGURA 4.58 Evolução dos momentos fletores - modelo Mac experimental

FIGURA 4.59 Deslocamentos experimentais- modelo Mac

FIGURA 4.60 Deformações experimentais na armadura negativa - modelo $\mathrm{Mac}$

FIGURA 4.61 Deformações experimentais no concreto - modelo Mac 
FIGURA 4.62 Fissuração devido atuação do momento fletor negativo modelo Mac

FIGURA 4.63 Evolução da abertura de fissuras sobre o apoio central modelo Mac

FIGURA 4.64 Deformações na armadura negativa ao longo do seu eixo Mac

FIGURA 5.1 Evolução dos momentos fletores experimentais nos modelos M15, M40 e Mac

FIGURA 5.2 Ensaio da faixa de laje nas etapas finais de carga

FIGURA 5.3 Deslocamentos experimentais no meio do vão 100

FIGURA 5.4 Discretização das faixas de lajes

FIGURA 5.5 Esquema de forças concentradas utilizadas nas modelagens numéricas

FIGURA 5.6 Seções de referência em que foram calculadas as características mecânicas e geométricas dos modelos teóricos

FIGURA 5.7 Máximos momentos fletores - modelo M15

FIGURA 5.8 Deslocamentos teóricos e experimentais - modelo M15 ....... 105

FIGURA 5.9 Máximos momentos fletores - modelo M40 _....................... 107

FIGURA 5.10 Deslocamentos teóricos e experimentais - modelo M40 ...... 107

FIGURA 5.11 Máximos momentos fletores - modelo Mac ......................... 109

FIGURA 5.12 Deslocamentos teóricos e experimentais - modelo Mac ....... 110

FIGURA 5.13 Momentos fletores com resistência à tração e capacidade de rotação ajustados - modelo M15

FIGURA 5.14 Deslocamentos com resistência à tração e capacidade de rotação ajustados - modelo M15

FIGURA 5.15 Momentos fletores com resistência à tração e capacidade de rotação ajustados - modelo M40

FIGURA 5.16 Deslocamentos com resistência à tração e capacidade de rotação ajustados - modelo M40

FIGURA 5.17 Momentos fletores com resistência à tração e capacidade de rotação ajustados - modelo Mac 
FIGURA 5.18 Deslocamentos com resistência à tração e capacidade de rotação ajustados - modelo Mac

FIGURA 5.19 Diagrama momento x curvatura teórico

FIGURA 5.20 Efeito da discretização na curvatura média

FIGURA 5.21 Diagrama momento x curvatura obtido com os dados de ensaio

FIGURA 5.22 Rigidez à flexão $\mathrm{x}$ força aplicada - análise teórica do modelo M15

FIGURA 5.23 Rigidez à flexão x força aplicada - análise teórica do modelo M40

FIGURA 5.24 Rigidez à flexão $\mathrm{x}$ força aplicada - análise teórica do modelo Mac

FIGURA 5.25 Evolução dos deslocamentos teóricos -modelo M15

FIGURA 5.26 Evolução dos deslocamentos - Análise teórica do modelo M40

FIGURA 5.27 Evolução dos deslocamentos - Análise teórica do modelo Mac

FIGURA 5.28 Máximos momentos fletores teóricos dos modelos M0, M15, M40 e Mac

FIGURA 5.29 Deslocamentos teóricos - modelo M0

FIGURA 5.30 Evolução dos deslocamentos - Análise teórica do modelo M0

FIGURA 5.31 Rigidez à flexão x força aplicada - análise teórica do modelo M0

FIGURA A.1 Deslocamentos dos apoios - M15

FIGURA A.2 Deslocamentos dos apoios - M40

FIGURA A.3 Deslocamentos dos apoios - Mac

FIGURA A.4 Deslocamentos a $1 \mathrm{~m}$ dos eixos dos apoios externos - M15 ..

FIGURA A.5 Deslocamentos a 1m dos eixos dos apoios externos - M40 ..

FIGURA A.6 Deslocamentos a $1 \mathrm{~m}$ dos eixos dos apoios externos - Mac ..

FIGURA A.7 Deslocamentos no meio do vão - M15 A4

FIGURA A.8 Deslocamentos no meio do vão - M40 
FIGURA A.9 Deslocamentos no meio do vão - Mac

FIGURA A.10 Deslocamentos a $1 \mathrm{~m}$ do eixo do apoio interno - M15 ......... A6

FIGURA A.11 Deslocamentos a $1 \mathrm{~m}$ do eixo do apoio interno - M40 ......... A6

FIGURA A.12 Deslocamentos a $1 \mathrm{~m}$ do eixo do apoio interno - Mac .......... A7

FIGURA A.13 Deslocamentos a $25 \mathrm{~cm}$ do eixo do apoio interno - M15 ....... A7

FIGURA A.14 Deslocamentos a $25 \mathrm{~cm}$ do eixo do apoio interno - M40 ...... A8

FIGURA A.15 Deslocamentos a $25 \mathrm{~cm}$ do eixo do apoio interno - Mac ....... A8

FIGURA A.16 Deformações na armadura negativa nos pontos instrumentados a $25 \mathrm{~cm}$ do eixo do apoio interno - M15 ....... A9

FIGURA A.17 Deformações na armadura negativa nos pontos instrumentados a $25 \mathrm{~cm}$ do eixo do apoio interno - M40 ...... A9

FIGURA A.18 Deformações na armadura negativa nos pontos instrumentados a $25 \mathrm{~cm}$ do eixo do apoio interno - Mac ....... A10

FIGURA A.19 Deformações na armadura negativa nos pontos instrumentados a $10 \mathrm{~cm}$ do eixo do apoio interno - M15 ...... A10

FIGURA A.20 Deformações na armadura negativa nos pontos instrumentados a $10 \mathrm{~cm}$ do eixo do apoio interno - M40 ....... A11

FIGURA A.21 Deformações na armadura negativa nos pontos instrumentados a $10 \mathrm{~cm}$ do eixo do apoio interno - Mac ....... A11

FIGURA A.22 Deformações na armadura negativa nos pontos instrumentados no eixo do apoio interno - M15 .................. A12

FIGURA A.23 Deformações na armadura negativa nos pontos instrumentados no eixo do apoio interno - M40

FIGURA A.24 Deformações na armadura negativa nos pontos instrumentados no eixo do apoio interno - Mac ................... A13

FIGURA A.25 Deformações no concreto - M15 …...................................... A13

FIGURA A.26 Deformações no concreto - M40 …...................................... A14

FIGURA A.27 Deformações no concreto - Mac ............................................ A14

FIGURA A.28 Deformações no fio do banzo inferior da armação treliçada $-\mathrm{M} 15$

FIGURA A.29 Deformações no fio do banzo inferior da armação treliçada - M40 . 
FIGURA A.30 Deformações no fio do banzo inferior da armação treliçada - Mac

FIGURA A.31 Deformações no fio do banzo superior da armação treliçada $-\mathrm{M} 15$

FIGURA A.32 Deformações no fio do banzo superior da armação treliçada - M40

FIGURA A.33 Deformações no fio do banzo superior da armação treliçada - Mac 


\section{LISTA DE TABELAS}

TABELA 2.1 Capa mínima resistente para as alturas totais padronizadas [Projeto de norma para Laje pré-fabricada] ......................... 16

TABELA 4.1 Armadura de flexão dos modelos M15, M40 e Mac ............. 57

TABELA 4.2 Propriedades dos concretos ................................................. 75

TABELA 4.3 Caracterização da armadura negativa .................................. 77

TABELA 5.1 Resultados experimentais .................................................... 96

TABELA 5.2 Características geométricas e mecânicas das seções de referência - modelo M15 .................................................. 104

TABELA 5.3 Características geométricas e mecânicas das seções de referência - modelo M40 ................................................. 106

TABELA 5.4 Características geométricas e mecânicas das seções de referência - modelo Mac ................................................. 109

TABELA 5.5 Comparações entre capacidade de rotações plásticas ........... 118

TABELA 5.6 Armaduras de flexão do modelo M0 ..................................... 124

TABELA 5.7 Características geométricas e mecânicas das seções de referência - modelo M0 .................................................... 124 


\section{RESUMO}

MAGALHÃES, F. L. (2001). Estudo dos momentos fletores negativos nos apoios de lajes formadas por elementos pré-moldados tipo nervuras com armação treliçada. São Carlos, 2001. 135p + apêndice. Dissertação (Mestrado) - Escola de Engenharia de São Carlos, Universidade de São Paulo.

Este trabalho aborda um dos tipos construtivos mais empregados em lajes de edificações no Brasil, que são as lajes com nervuras pré-moldadas com armação treliçada. O objetivo principal do trabalho é contribuir na avaliação da continuidade estrutural relativa aos momentos fletores negativos nos apoios destas lajes. Para a realização deste trabalho, as lajes em concreto pré-moldado formadas por vigota com armação treliçada foram analisadas segundo modelos teóricos e experimentais. $\mathrm{Na}$ análise teórica, a consideração da não-linearidade física do concreto é realizada a partir do uso da relação momento $x$ curvatura proposta pelo código modelo CEB-90 em conjunto com a técnica do carregamento incremental. Os resultados do modelo teórico são confrontados com os resultados obtidos em ensaios experimentais de faixas de lajes contínuas dimensionadas com diferentes graus de redistribuição dos momentos fletores negativos. Nas análises realizadas observa-se que: a) o modelo teórico apresenta bons resultados comparados aos resultados experimentais, b) as lajes apresentam boa capacidade de rotação plástica, c) com alta taxa de armadura negativa não ocorre redistribuição de esforços, d) as flechas praticamente independem da taxa de armadura negativa e e) a força última é praticamente independente do grau de redistribuição adotado no dimensionamento.

Palavras-chaves: Laje pré-moldada, concreto armado, comportamento não-linear, rotações plásticas, análise experimental, redistribuição de esforços. 


\begin{abstract}
MAGALHÃES, F. L. (2001). Bending moments in the support of slabs made by precast joist with lattice reinforcement. São Carlos. 135p + appendix. Dissertation (Marter's Degree) - Escola de Engenharia de São Carlos, Universidade de São Paulo.
\end{abstract}

This work deal with an usual type of slab in Brazil: slabs made by precast joist with lattice reinforcement. The goal of this work is the structural analysis of bending moments in the supports of slabs made by this kind of precast element. Theoretical and experimental models analyze this type of slab. In the theoretical analysis, the non-linear concrete behavior is done by moment $x$ curvature relationship of Model Code CEB-90 add incremental load technique. The theoretical model is compared with experimental results of continuous strip slabs designed with different degrees of bending moment redistribution. In these analysis had been noted: a) the theoretical model presents good results compared with the experimental results, b) the slabs present good plastic rotation capacity, c) with high negative reinforcement ratio in the support does not happen moment redistribution, d) the displacement is practically independent of negative reinforcement ratio and e) the ultimate load is practically independent of redistribution degree idealized in the design.

Keywords: Precast slabs, reinforced concrete, non-linear behavior, plastic rotations, experimental analysis, bending redistribution. 


\subsection{Considerações iniciais}

Atualmente está se tornando comum nos pavimentos de edifícios a utilização de vãos cada vez maiores e em muitos casos são dispostas paredes de alvenaria diretamente sobre as lajes.

A utilização de lajes maciças nesses pavimentos conduz a espessuras maiores que aquelas usualmente encontradas nos edifícios com vãos menores e paredes de alvenaria dispostas sobre vigas. Com isto, a estrutura se torna antieconômica, pois parte da capacidade resistente da laje é utilizada para combater as solicitações decorrentes do peso próprio.

Como projetistas e construtores sempre buscam meios para diminuir os custos das construções, principalmente no Brasil que possui um alto déficit habitacional aliado a um baixo poder aquisitivo da população, é importante usar soluções estruturais de baixo custo, simples execução e que tenham qualidade satisfatória com comportamento adequado e seguro.

Uma das possibilidades de se reduzir o peso próprio da laje e ainda conseguir vãos maiores é a partir do emprego de lajes nervuradas, sistema estrutural onde parte do concreto abaixo da linha neutra é eliminado. O grande problema desse sistema está relacionado com as fôrmas e escoramentos, pois além do custo destes materiais, necessitam de um maior volume de mão-de-obra para a sua confecção. 
Com a execução das lajes nervuradas a partir de vigotas pré-moldadas, elementos de enchimento e concreto moldado in loco, as fôrmas e os escoramentos podem sofrer reduções significativas. Se estas lajes forem bem dimensionadas e executadas, apresentam desempenho satisfatório e compatível com suas características tecnológicas.

As lajes formadas por vigotas pré-moldadas foram disseminadas no Brasil por inúmeras pequenas empresas produtoras, muitas delas sem capacitação técnica suficiente para projetar, produzir os elementos e prestar assistência aos construtores. Muitas vezes esse fato compromete a segurança da estrutura, propiciando problemas estruturais usualmente observados em obras, tais como flechas excessivas, fissurações, infiltrações e, em certos casos, podendo ocorrer riscos de desabamento.

Apesar de todas as vantagens que este sistema estrutural apresenta, tanto os estudos teóricos como os experimentais ainda permanecem bastante limitados, resultando num pequeno número de trabalhos técnicos. A maior parte das recomendações existentes é apresentada por meio de publicações de catálogos técnicos de empresas fabricantes dos elementos pré-moldados. A NBR-6118 (1978) não trata especificamente das lajes formadas por vigotas pré-moldadas e outras normas são eventualmente consultadas.

No contexto de intensa utilização e informações ainda limitadas, sente-se a necessidade de se aprofundar nos estudos teóricos e experimentais em lajes formadas por vigotas pré-moldadas, também chamada simplificadamente de laje prémoldada, de modo a regulamentar e orientar projetistas e construtores.

\subsection{Objetivos}

Esta dissertação é direcionada para o estudo dos momentos fletores negativos das lajes formadas por elementos pré-moldados tipo vigota com armação treliçada. 


\section{Objetivo geral:}

Contribuir na avaliação do comportamento de lajes formadas por elementos pré-moldados tipo nervuras com armação em forma de treliças, mediante estudo dos momentos fletores negativos junto aos apoios de lajes unidirecionais contínuas.

\section{Objetivos específicos:}

- Avaliar o comportamento de lajes nervuradas unidirecionais contínuas formadas por elementos pré-moldados com armação treliçada, ao serem utilizadas diferentes taxas de armadura de flexão.

- Avaliar a capacidade de rotação plástica nas regiões dos apoios internos em faixas de lajes nervuradas unidirecionais contínuas formadas por elementos pré-moldados com armação treliçada.

- Analisar a importância da redistribuiçãa de esforços.

- Analisar o efeito da redistribuição de esforços no comportamento em serviço da estrutura.

- $\quad$ Fornecer indicações de projeto para a consideração da continuidade em relação aos momentos fletores negativos.

\subsection{Justificativas}

A importância e relevância deste trabalho de pesquisa estão calcadas nos seguintes aspectos:

a) a dissertação corresponde a uma continuidade da pesquisa no assunto iniciado por DROPPA JÚNIOR (1999), objetivando complementar o entendimento de um tipo de laje bastante difundido no país;

b) na literatura técnica internacional existem poucos trabalhos de pesquisa sobre as lajes formadas por nervuras pré-moldadas e este panorama se repete em nível nacional; 
c) não existe um critério racional por parte dos projetistas para adotar o momento fletor de continuidade;

d) no presente momento está sendo elaborada a Norma para a Laje PréFabricada, que por falta de estudos, não inclui no texto atual nada sobre este assunto.

\subsection{Metodologia}

Inicialmente procurou-se realizar uma ampla revisão bibliográfica de modo a se obter informações disponíveis na literatura técnica referentes ao tema. No desenvolvimento do trabalho de pesquisa foi prevista a realização de uma parte teórica e de uma parte experimental.

A parte teórica consistiu na análise de lajes nervuradas com a consideração da não-linearidade física do concreto feita a partir do uso da relação momento $x$ curvatura proposta pelo código modelo CEB-90 (1991) em conjunto com a técnica do carregamento incremental.

Essas análises teóricas foram realizadas a partir de modelagens numéricas em computador utilizando o programa ANSYS ${ }^{\circledR}$, disponível no Departamento de Engenharia de Estruturas da EESC-USP. O ANSYS ${ }^{\circledR}$ utiliza o método dos elementos finitos para obtenção de esforços e deslocamentos provocados pela ação do carregamento numa estrutura.

Para considerar a não-linearidade física do concreto, foram acopladas ao ANSYS $^{\circledR}$, por meio de macros ou sub-rotinas, a técnica do carregamento incremental e a relação momento $x$ curvatura proposta pelo código modelo CEB-90 (1991).

Na parte experimental do trabalho foram realizados ensaios de flexão em faixas contínuas de lajes nervuradas feitas com vigotas pré-moldadas tipo armação treliçada, elementos de enchimento em EPS e concreto moldado in loco. Cada faixa de laje ensaiada representa uma situação típica de projeto, onde uma determinada redistribuição de momentos fletores é considerada no dimensionamento e, assim, diferentes taxas de armaduras são utilizadas.

Os resultados obtidos nos ensaios são confrontados com os resultados das modelagens numéricas utilizando o modelo teórico proposto. A partir da análise de 
resultados, são fornecidas indicações de projeto para a consideração da continuidade em relação aos momentos fletores negativos.

\subsection{Apresentação do trabalho}

Esta dissertação está dividida em 6 capítulos, apresentando-se a seguir, sucintamente, o conteúdo de cada um deles.

O capítulo 1 apresenta os objetivos, as justificativas e a metodologia do trabalho.

No capítulo 2 são apresentadas as lajes formadas por elementos prémoldados com armação treliçada, enfatizando a sua análise estrutural, o dimensionamento e as formas para consideração da redistribuição dos esforços durante a fase de dimensionamento.

A metodologia utilizada para o desenvolvimento das análises teóricas é apresentada no capítulo 3. Inicialmente são apresentadas as relações momento $x$ curvatura do CEB-90 (1991) e a técnica do carregamento incremental. Em seguida são discorridas algumas considerações sobre a capacidade de rotação das rótulas plásticas e os critérios adotados para a sua consideração neste trabalho.

No capítulo 4 são mostrados os detalhes do programa experimental.

No capítulo 5 são realizadas as análises dos resultados obtidos nos ensaios e nas modelagens numéricas.

As conclusões deste trabalho são apresentadas no capítulo 6. Ainda neste capítulo serão apresentadas sugestões para a continuidade deste trabalho. 


\section{LAJES FORMADAS POR ELEMENTOS PRÉ- MOLDADOS}

\subsection{Considerações iniciais}

Uma das aplicações mais comuns de elementos de concreto pré-moldado no Brasil é nas lajes de edifícios. Segundo EL DEBS (2000), as principais variações que são utilizadas são:
a) painéis TT,
b) painéis alveolares
c) elementos de pré-laje
d) lajes formadas por nervuras pré-moldadas, comumente chamadas de "lajes pré-moldadas" ou "lajes pré-fabricadas".
As lajes pré-moldadas são constituídas basicamente de (figura 2.1):
a) elementos lineares pré-moldados, comumente chamados nervuras ou vigotas, dispostos espaçadamente em uma direção;
b) elementos de enchimento, posicionados entre os elementos pré- moldados;
c) concreto moldado no local.




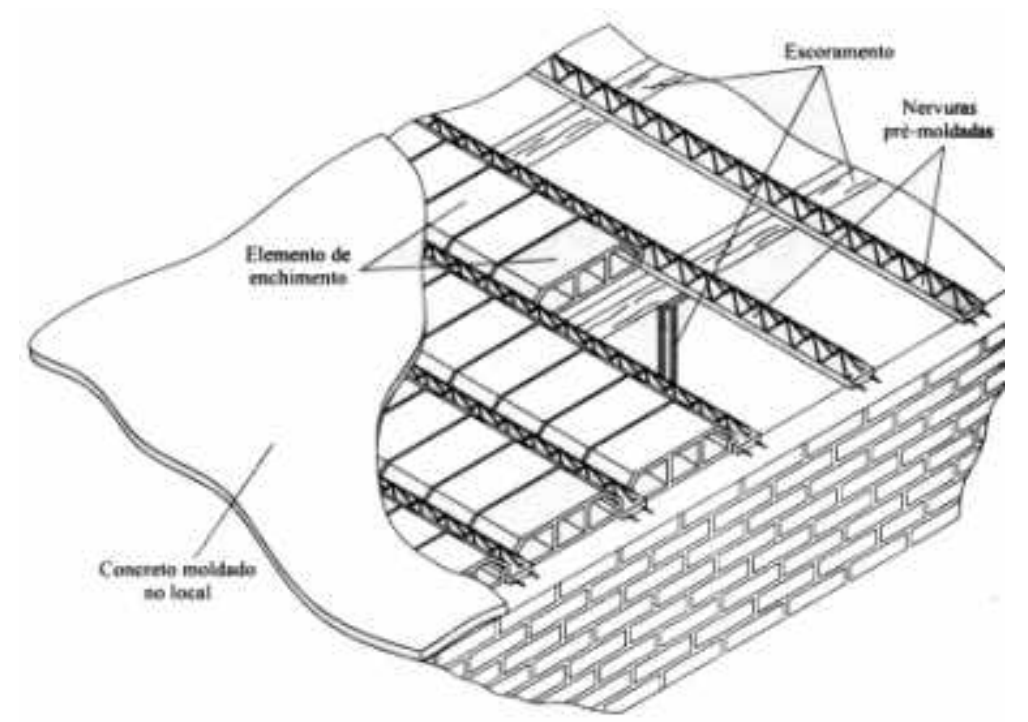

FIGURA 2.1 - Laje formada por nervuras pré-moldadas [EL DEBS (2000)]

Com relação às seções transversais, os elementos pré-moldados podem ser com ou sem armadura saliente, em forma de $\mathrm{T}$ invertido ou I. Os materiais de enchimento normalmente utilizados são blocos vazados de concreto ou material cerâmico, ou ainda blocos de poliestireno expandido, conhecidos pela sigla EPS.

A utilização de elementos de material leve está ligada à idéia de substituir parte do concreto da região tracionada das lajes como forma de redução do peso próprio, bem como servir de sustentação à camada de concreto fresco que é aplicada sobre os painéis das lajes pré-moldadas para a solidarização dos elementos.

Atualmente, o mercado brasileiro dispõe dos seguintes tipos de vigotas pré-moldadas (figura 2.2):

a) vigotas de concreto armado não protendido, com seção transversal com a forma aproximada de um $\mathrm{T}$ invertido, com armadura passiva totalmente envolvida pelo concreto;

b) vigotas de concreto protendido, com seção transversal com a forma aproximada de um $\mathrm{T}$ invertido, com armadura de protensão prétracionada e totalmente envolvida pelo concreto

c) vigotas com armação treliçada, formadas por uma armação treliçada de aço e por uma base de concreto envolvendo as barras inferiores da treliça.

Normalmente, as vigotas pré-moldadas em concreto armado não protendido (comumente chamadas de Volterrana) atingem vãos da ordem de $5 \mathrm{~m}$ e as 
vigotas pré-moldadas em concreto protendido ou armação treliçada podem atingir vãos da ordem de $10 \mathrm{~m}$ ou mais.

Além da aplicação destes elementos em obras de pequeno porte, deve-se destacar que recentemente as lajes formadas por elementos pré-moldados têm avançado rumo aos edifícios com maior número de pavimentos, utilizando-se vigotas com armadura protendida ou vigotas com armação em forma de treliça.

As lajes pré-moldadas podem ter nervuras principais em uma ou em duas direções sendo classificadas como lajes unidirecionais ou bidirecionais, respectivamente. A laje pré-moldada unidirecional possui nervuras principais dispostas em uma única direção, sendo formada por vigotas pré-moldadas posicionadas na direção principal da laje, complementadas por concreto moldado no local. Mesmo nas situações em que são adotadas nervuras transversais de travamento, esta laje ainda é classificada como unidirecional.

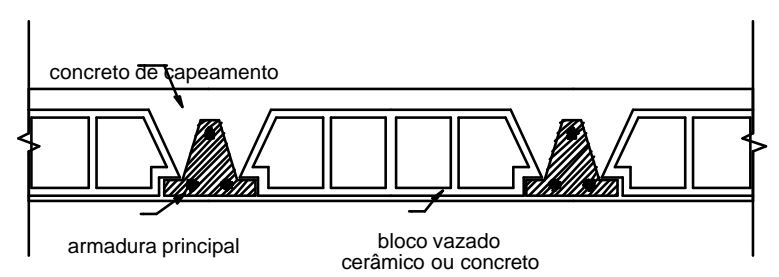

vigota de concreto armado não protendido

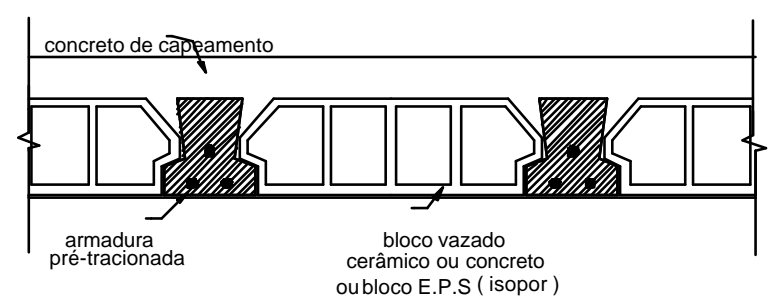

vigota de concreto armado protendido

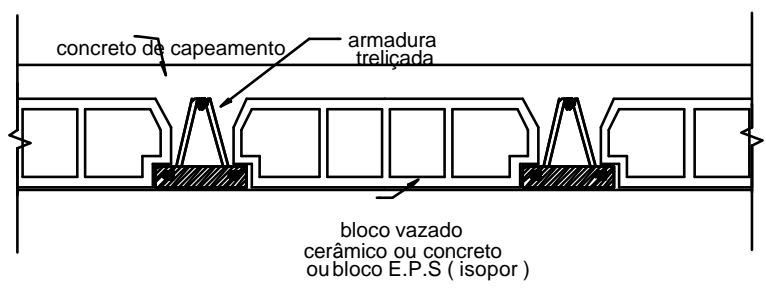

vigota com armação treliçada

FIGURA 2.2- Vigotas pré-moldadas disponíveis no mercado brasileiro 
A laje pré-moldada bidirecional possui nervuras resistentes em duas direções ortogonais entre si. Normalmente, esta laje é construída dispondo-se vigotas pré-moldadas com armação treliçada na direção do menor vão e pelas nervuras transversais moldadas in loco na outra direção. Ressalta-se que as lajes pré-moldadas bidirecionais ficam bem executadas com a utilização de vigotas com armação treliçada, uma vez que estas permitem a passagem e a colocação da armadura na direção transversal aos elementos pré-moldados.

\subsection{Lajes nervuradas formadas por vigotas pré-moldadas com armação treliçada ${ }^{1}$}

Devido à solidarização da armação treliçada com o concreto moldado no local, as lajes com vigotas treliçadas podem ser tratadas como estruturas monolíticas. A princípio, estas lajes possuem um comportamento semelhante a uma laje projetada da forma convencional, sendo que os elementos pré-moldados têm a função de racionalização na execução, proporcionando à obra rapidez e economia.

A armação treliçada é uma estrutura formada por barras de aço solidarizadas por meio de soldagem por eletrofusão em alguns pontos de modo a formar uma treliça espacial. As diagonais desta treliça proporcionam:

a) rigidez ao conjunto nas fases transitórias;

b) excelentes condições de transporte e manuseio;

c) ligação entre o concreto moldado no local e o concreto da base prémoldada;

d) podem ser utilizadas como armaduras transversais para combater tensões de cisalhamento.

A armação treliçada pode ser classificada a partir de um código que relaciona a sua altura com os diâmetros das armaduras do banzo superior, das diagonais (comumente chamada de senusóide) e do banzo inferior. Por exemplo, a armação treliçada TR08634 possui $\underline{8} \mathrm{~cm}$ de altura, barra de $\underline{6}, 0 \mathrm{~mm}$ de diâmetro no

\footnotetext{
${ }^{1}$ Indica-se a partir de agora como lajes com vigotas treliçadas
} 
banzo superior, $\underline{3}, 4 \mathrm{~mm}$ de diâmetro nas diagonais e $\underline{4}, 2 \mathrm{~mm}$ de diâmetro no banzo inferior. Nas figuras 2.3 e 2.4 estão mostrados os elementos que compõem uma vigota pré-moldada com armação treliçada.

Sob encomenda, as vigotas pré-moldadas com armação treliçada podem ser fabricadas com armaduras adicionais introduzidas na base pré-moldada de concreto sem que isto acarrete dificuldades no processo de fabricação. A área desta armadura adicional é especificada pelo engenheiro projetista (figura 2.4).

A base de concreto é moldada em fôrmas metálicas com espessuras de 2 a $3 \mathrm{~cm}$, empregando-se concreto de agregado miúdo.

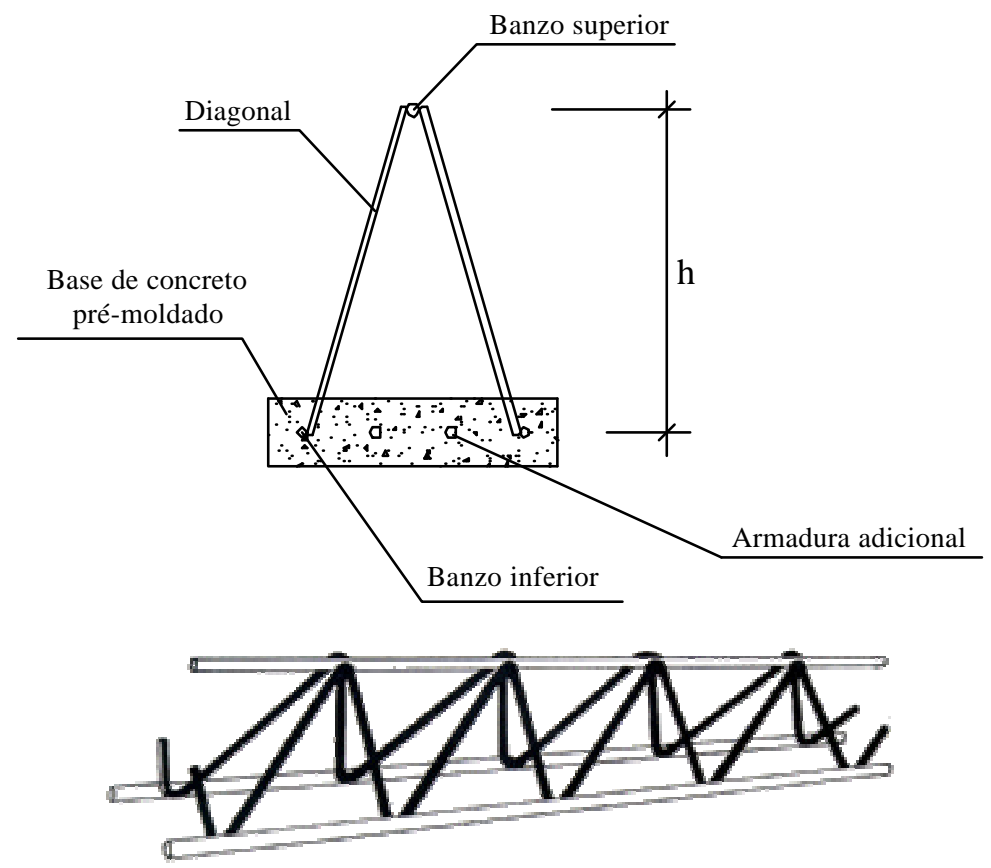

FIGURA 2.3- Seção da vigota com armadura em forma de treliça e perspectiva da armação treliçada

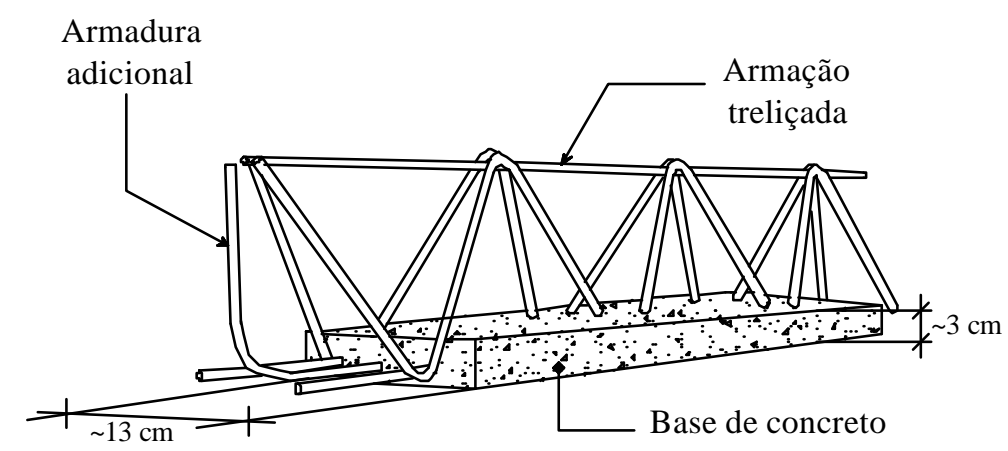

FIGURA 2.4- Vigota com armação em forma de treliça 
EL DEBS (2000) destaca que a utilização de vigotas pré-moldadas com armação em forma de treliça favorece a utilização das lajes armadas nas duas direções (lajes bidirecionais). Neste tipo de laje aplicam-se as indicações de projeto das lajes nervuradas ou mistas das estruturas de concreto moldado no local, com as particularidades do concreto pré-moldado apenas no que se refere às situações transitórias. Esta possibilidade de laje armada em duas direções tem sido explorada no país há algum tempo em pavimentos, com e sem vigas, principalmente utilizando enchimento, recuperado ou não, de EPS.

Em relação ao sistema tradicional de lajes maciças, as lajes com armação treliçada apresentam as seguintes vantagens [MUNIZ (1991)]:

- diminuição do peso próprio da laje e o conseqüente alívio sobre as fundações;

- a possibilidade de embutir todas as instalações elétricas entre a capa de concreto e a base de concreto pré-moldado;

- $\quad$ em função do bom acabamento e regularidade superficiais dos elementos pré-moldados, na face inferior é requerida apenas uma fina camada de regularização;

- redução significativa de fôrmas, acarretando economia de madeiramento e evitando desperdícios com engrossamento desnecessário dos perfis concretados;

- $\quad$ sensível redução do escoramento das lajes, já que se recomenda apenas a colocação de escoras com travessas a cada 1,5 m durante a fase de cura da capa do concreto;

- em lajes contínuas, o uso de vigotas com armação treliçada permite a continuidade estrutural pela colocação de armadura negativa sobre os apoios, sem que isto signifique qualquer problema para a sua fixação;

- sendo a armação treliçada fabricada a partir de rolos de fios de aço trefilados CA-60, eliminam-se as perdas das pontas dos vergalhões utilizados na preparação da armadura no canteiro;

- reduz a quantidade de estoque e movimentação de materiais e pessoas no canteiro de obras, diminui a mão-de-obra de ferreiros, armadores e carpinteiros e aumenta a rapidez da construção da estrutura. 
$\mathrm{Na}$ utilização das vigotas pré-moldadas com armação treliçada, as seguintes podem ser destacadas [DROPPA JÚNIOR (1999)]:

- reduz o aparecimento de fissuras pela condição de aderência entre o concreto do capeamento e o concreto da vigota pré-moldada;

- facilita a colocação de nervuras moldadas in loco na direção perpendicular às vigotas;

- $\quad$ pode oferecer maior resistência ao cisalhamento em função da presença das diagonais da treliça.

Apesar das inúmeras vantagens apresentadas, como em qualquer outro sistema construtivo, alguns cuidados devem ser tomados para que as lajes com elementos pré-moldados tipo armação treliçada apresentem um comportamento adequado, atendendo aos estados limites de utilização e estados limites últimos. Dentre os cuidados adicionais em que os projetistas e construtores devem dar maior atenção na utilização deste sistema construtivo, os seguintes devem ser destacados:

- A armadura das diagonais poderá ser considerada colaborante na resistência ao cisalhamento somente se estiver eficazmente ancorada na região comprimida do concreto.

- Em lajes contínuas, deve-se verificar o posicionamento da armadura negativa durante o lançamento e adensamento do concreto, de modo a garantir o valor de altura útil (d) especificado em projeto.

- Sendo estas lajes formadas por elementos esbeltos, em edifícios com maior número de pavimentos deve-se analisar a resistência do plano da laje na transferência de ações horizontais, de modo que as lajes prémoldadas com armação treliçada apresentem comportamento efetivo de diafragma.

- $\quad$ Por serem formadas por elementos muito esbeltos, deve ser verificado o comportamento para o estado limite de deformações excessivas.

No presente momento está em estudo no CB-02 - Comitê Brasileiro de Construção Civil o documento NBR/PROJETO 02:107.01-001, versão 29/5/00 para a elaboração da Norma para Laje Pré-Fabricada. Com isso, os procedimentos de 
cálculo que os projetistas normalmente têm em mãos para realizar o dimensionamento e verificação de lajes com armação treliçada são encontrados em publicações feitas por empresas fabricantes dos elementos pré-moldados, podendo-se citar, dentre outros, DINIZ (1988), LIMA (1993), FRANCA \& FUSCO (2000) e PEREIRA (2000).

BORGES (1997) reuniu informações técnicas sobre a utilização deste sistema construtivo, apresentando um roteiro prático para dimensionamento utilizando as recomendações da NBR-6118 (1978) e sugerindo critérios para projeto das nervuras transversais às vigotas.

Mais recentemente, DROPPA JÚNIOR (1999) realizou estudos teóricos nas lajes com armação treliçada por meio de simulações em programas de computador, sendo o estudo direcionado a painéis de lajes unidirecionais e bidirecionais. Nesse trabalho, a laje foi estudada mediante a analogia de grelha com a consideração da não-linearidade física do concreto, fazendo análises comparativas de valores teóricos e experimentais disponíveis em vigas e em lajes.

Apesar do trabalho de DROPPA JÚNIOR (1999) ter avançado significativamente no entendimento deste tipo de laje, algumas dúvidas ainda persistem. Um dos assuntos que permanece com mais incertezas e que não se dispõe de resultados experimentais, é sobre a transmissão de momentos fletores negativos nos apoios das lajes contínuas. Além do comportamento dos momentos fletores negativos ser diferente dos momentos fletores positivos, neste tipo de laje existem variações, como:

a) as nervuras principais estão dispostas em uma direção num tramo da laje e perpendiculares no outro tramo;

b) podem ser feitos alargamentos da seção de concreto junto ao apoio, mediante a retirada de material de enchimento. 


\subsection{Análise estrutural de lajes nervuradas}

A laje pré-moldada com armação treliçada pode ser considerada, apesar das suas particularidades descritas anteriormente, uma laje nervurada. A laje nervurada pode ser encarada como uma alternativa da laje maciça onde se procurou eliminar parte do concreto tracionado criando-se vazios para que fosse possível aumentar a altura da laje sem necessariamente representar aumento do consumo de concreto.

De uma maneira geral, as lajes nervuradas são usadas para vencer grandes vãos, sendo necessário formar um sistema estrutural altamente eficiente, constituído por um conjunto de nervuras dispostas em uma ou duas direções, com espaçamentos regulares entre si.

De acordo com a NBR-6118 (1978), no cálculo de lajes nervuradas devem ser observadas as seguintes prescrições:

- A distância livre entre nervuras não deve ultrapassar $100 \mathrm{~cm}$.

- A espessura das nervuras não deve ser inferior a $4 \mathrm{~cm}$.

- $\quad$ A espessura da mesa não deve ser menor que $4 \mathrm{~cm}$ ou a $1 / 15$ da distância livre entre nervuras.

- $\quad \mathrm{O}$ apoio das lajes deve ser feito ao longo de uma nervura.

- $\quad$ Nas lajes armadas em uma direção, são necessárias nervuras transversais sempre que houver cargas concentradas a distribuir ou quando o vão teórico for superior a $4 \mathrm{~m}$, exigindo no mínimo duas nervuras se esse vão ultrapassar $6 \mathrm{~m}$.

- Nas nervuras com espessura inferior a $8 \mathrm{~cm}$ não é permitido colocar armadura de compressão no lado aposto à mesa.

- A resistência à flexão da mesa deverá ser verificada sempre que a distância livre entre as nervuras superar $50 \mathrm{~cm}$ ou quando existir carga concentrada no painel entre as nervuras.

- As nervuras deverão ser verificadas ao cisalhamento, como vigas, se a distância livre entre elas for superior a $50 \mathrm{~cm}$ e como laje em caso contrário. 
$\mathrm{Na}$ definição da seção transversal da laje nervurada é feita uma analogia em que a capa de concreto moldado in loco é uma laje maciça e as nervuras formam um conjunto de vigas. Utilizando-se os preceitos da NBR 6118 (1978), a parte de laje a ser considerada como elemento de viga será determinada, conforme nomenclatura da figura 2.5, a partir da seguinte expressão:

$$
b_{f}=b_{w}+2 \cdot b_{1}
$$

Onde:

$$
\mathrm{b}_{1} \leq\left\{\begin{array}{l}
0,10 . \mathrm{a} \\
8 . \mathrm{h}_{\mathrm{f}} \\
0,5 \cdot \mathrm{b}_{2}
\end{array}\right.
$$

O parâmetro a depende da distância entre momentos fletores nulos, podendo ser estimado em função do comprimento do vão teórico $\ell$ do tramo considerado através das seguintes expressões:

- tramo simplesmente apoiado: $a=1,00 . \ell$

- tramo com momento em uma só extremidade: $\mathrm{a}=0,75 . \ell$

- tramo com momentos nas duas extremidades: $a=0,60 . \ell$

- tramo em balanço: $a=2 . \ell$

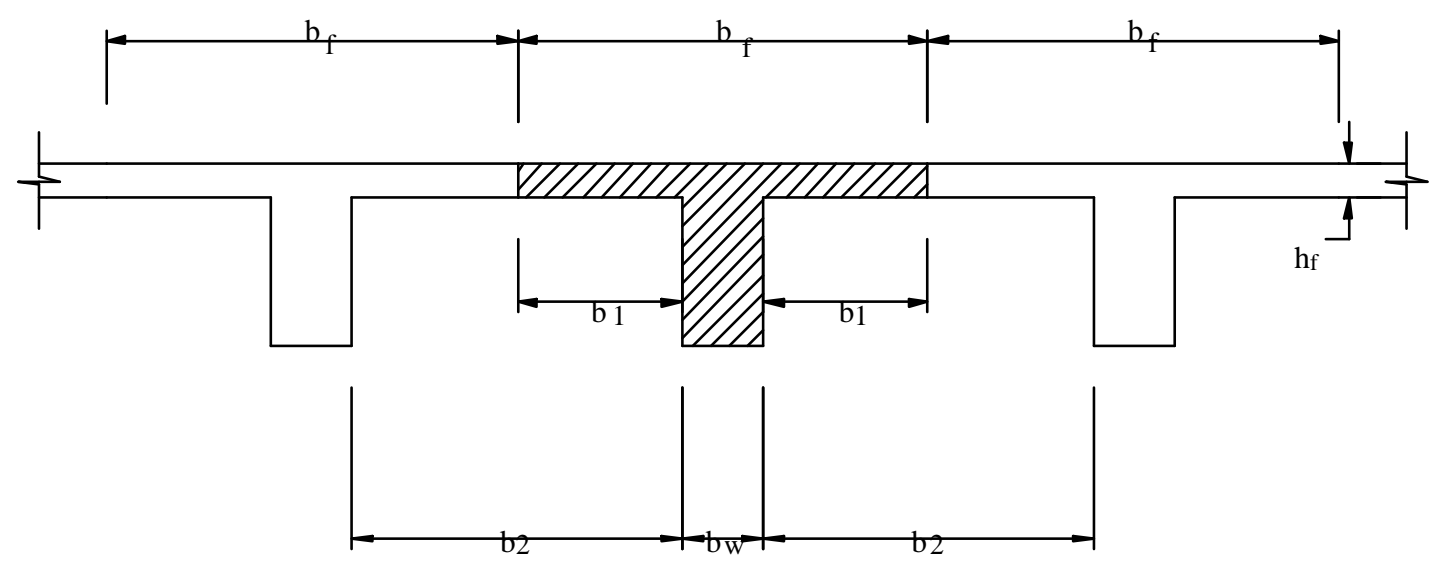

FIGURA 2.5- Largura efetiva da mesa de compressão

De acordo com o projeto de norma para Laje pré-fabricada, a mesa de compressão será considerada como parte resistente se sua espessura for no mínimo igual a $3 \mathrm{~cm}$. Existindo tubulações, a espessura mínima da capa de concreto acima da tubulação será no mínimo de $2 \mathrm{~cm}$, observados os limites estabelecidos na tabela 2.1. 
TABELA 2.1 - Capa mínima resistente para as alturas totais padronizadas [Projeto de norma para Laje pré-fabricada]

\begin{tabular}{|c|c|c|c|c|c|c|c|c|c|c|c|c|}
\hline Altura total da laje (cm) & 10,0 & 11,0 & 12,0 & 13,0 & 14,0 & 16,0 & 17,0 & 20,0 & 21,0 & 24,0 & 25,0 & 30,0 \\
\hline $\begin{array}{c}\text { Espessura mínima da } \\
\text { capa resistente (cm) }\end{array}$ & 3,0 & 4,0 & 4,0 & 4,0 & 4,0 & 4,0 & 4,0 & 4,0 & 4,0 & 4,0 & 5,0 & 5,0 \\
\hline
\end{tabular}

Conhecido o carregamento atuante, os esforços solicitantes nas lajes isoladas unidirecionais podem ser obtidos considerando o modelo de viga biapoiada e quando houver continuidade nos apoios intermediários, pode ser utilizado o modelo de viga contínua desde que se tenha segurança da capacidade da laje em transmitir os momentos fletores negativos.

Como as nervuras das lajes com vigotas treliçadas possuem seção transversal em forma de $\mathrm{T}$, as mesmas apresentam melhor desempenho para os momentos fletores positivos se comparados aos momentos fletores negativos. Com isto, os momentos fletores negativos que surgem a partir da análise linear com rigidez constante raramente são absorvidos pela nervura, já que nesta situação a mesma se comporta como seção retangular (figura 2.6).

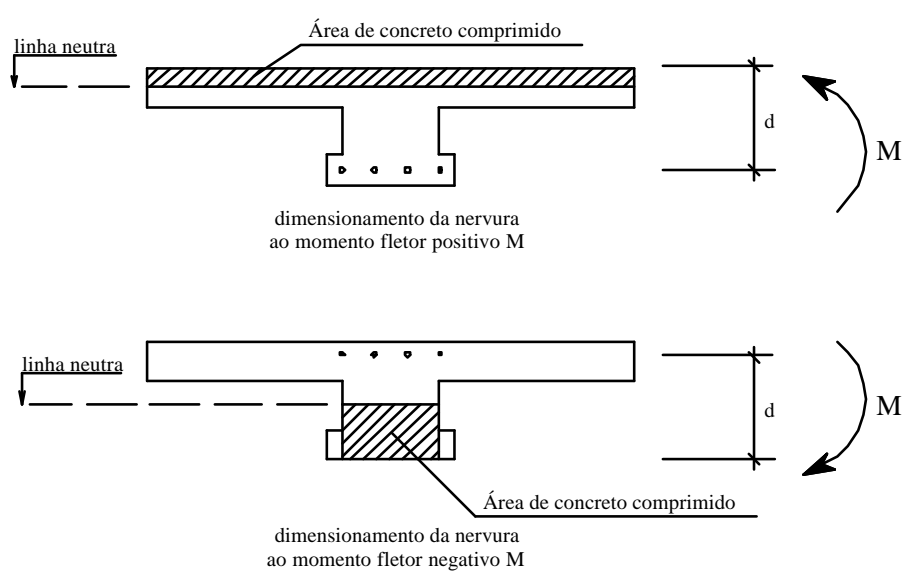

FIGURA 2.6- Dimensionamento da nervura - mesa comprimida e tracionada

No meio técnico, uma alternativa para fugir desta situação seria aumentar a área de concreto na região do apoio, transformado a laje nervurada em laje maciça nesta região. No entanto, esta solução representa aumento no consumo de concreto e fôrmas, além de diminuir a rapidez da construção e requisitar maior número de carpinteiros. 
Outra solução seria esquecer o modelo de viga contínua e simplesmente arbitrar os momentos fletores negativos aos valores dos momentos fletores que as seções retangulares são capazes de absorver. Como esses momentos fletores impostos possuem valores inferiores àqueles obtidos por uma análise linear e rigidez constante, o que na realidade se faz é um cálculo plástico.

Mesmo que a laje tenha sido dimensionada simplesmente apoiada, é recomendada a adoção de uma armadura construtiva sobre os apoios, e com isto reduzir a fissuração da mesma nestas regiões.

Uma vez determinados os esforços solicitantes, faz-se necessário verificar a segurança das lajes nervuradas em relação aos estados limites.

Os estados limites que uma estrutura pode atingir estão prescritos na NBR-8681 (1984). Entende-se por estados limites os estados a partir dos quais a estrutura apresenta desempenho inadequado às finalidades de sua construção.

O dimensionamento das lajes nervuradas é realizado no estado limite último de acordo com os preceitos da NBR-6118 (1978), considerando-se as ações majoradas em 1,4 e as resistências dos materiais aço e concreto minoradas em 1,15 e 1,4 , respectivamente.

A verificação e/ou dimensionamento ao cisalhamento é realizado segundo o anexo da NBR-7197 (1989), que modifica a NBR-6118 (1978). Quando houver necessidade da colocação de armadura transversal para combater as tensões de cisalhamento, pode-se contar com as diagonais inclinadas da armação treliçada, desde que a armação treliçada faça a ligação entre os banzos tracionados e comprimidos da nervura e o banzo superior da treliça esteja alojado na mesa de compressão de concreto.

$\mathrm{Na}$ verificação dos estados limites de utilização, no que diz respeito a verificação de deformações excessivas, pode ser utilizada a combinação quasepermanente das ações conforme prescreve o anexo da NBR-7197 (1989), podendo ser escrita da seguinte maneira:

$$
\mathrm{F}_{\mathrm{d}, \mathrm{qp}}=\mathrm{F}_{\mathrm{g}, \mathrm{k}}+\Psi_{2} \cdot \mathrm{F}_{\mathrm{q}, \mathrm{k}}
$$

Onde: $F_{d, q p}$ - ações quase-permanentes utilizadas na verificação do estado limite de deformações excessivas; 
$\mathrm{F}_{\mathrm{g}, \mathrm{k}}$ - ações permanentes, podendo ser peso próprio da laje, peso de alvenarias e revestimentos, etc;

$\mathrm{F}_{\mathrm{q}, \mathrm{k}}$ - ações principais acidentais, podendo ser cargas variáveis, sobrecarga de utilização, etc;

$\psi_{2}$ - fator de utilização quase-permanente, cujos valores estão definidos na NBR-8681 (1984).

Os deslocamentos máximos (flechas) medidos a partir do plano que passa pelos apoios estão limitados aos seguintes valores fornecidos pela NBR-6118 (1978):

- Quando atuarem todas as cargas para verificação do estado limite

- Não existindo balanços: $\ell / 300$

- Existindo balanços: $\ell / 150$

- Atuando somente as cargas acidentais

- Não existindo balanços: $\ell / 500$

- Existindo balanços: $\ell / 250$

Com relação às fissuras, estas não devem apresentar aberturas que ocasionem problemas relativos à funcionalidade e à durabilidade das estruturas de concreto armado.

A penetração de agentes agressivos através das fissuras, capazes de provocar a degradação na armadura e na massa de concreto, prejudica a durabilidade da estrutura. Com isso, a determinação da abertura de fissura deve ser feita também como função do meio em que a estrutura está inserida.

Além disso, vale salientar que fissuras demasiadamente abertas geram um certo desconforto psicológico aos usuários e prejudicam a aparência da estrutura.

Para verificação do estado limite de abertura de fissuras, deve ser considerada a combinação freqüente de utilização, na qual a ação variável é tomada com seu valor freqüente, podendo ser escrita da seguinte forma:

$\mathrm{F}_{\mathrm{d}, \text { freq }}=\mathrm{F}_{\mathrm{g}, \mathrm{k}}+\Psi_{1} \cdot \mathrm{F}_{\mathrm{q}, \mathrm{k}}$

Onde: $\quad \mathrm{F}_{\mathrm{d} \text {,freq }}$ - ações freqüentes utilizadas na verificação do estado limite de abertura de fissuras; 
$\psi_{1}$ - fator de utilização freqüente, cujos valores estão definidos na NBR-8681 (1984).

A verificação da fissuração é realizada estabelecendo valores máximos admissíveis para as aberturas de fissuras em função do meio no qual a estrutura será construída.

De acordo com NBR-6118 (1978), considera-se que a fissuração é nociva quando a abertura de fissuras (w) na superfície de concreto ultrapassa alguns dos seguintes valores:

a) $\quad \mathrm{W}_{\mathrm{lim}}=0,1 \mathrm{~mm}$ para peças não protegidas, em meio agressivo;

b) $\quad \mathrm{w}_{\mathrm{lim}}=0,2 \mathrm{~mm}$ para peças não protegidas, em meio não agressivo;

c) $\quad \mathrm{w}_{\lim }=0,3 \mathrm{~mm}$ para peças protegidas.

A abertura provável das fissuras é estimada em função das características das peças. Baseando-se nas prescrições das normas NBR-6118 (1978) e anexo da NBR-7197 (1989), a abertura nominal das fissuras (w) é dada pelo menor valor obtido considerando as seguintes expressões:

$$
\begin{aligned}
& \mathrm{w}=\frac{1}{10} \cdot \frac{\phi}{2 \cdot \eta_{\mathrm{b}}-0,75} \cdot \frac{\sigma_{\mathrm{s}}}{\mathrm{E}_{\mathrm{s}}} \cdot\left(\frac{4}{\rho_{\mathrm{r}}}+45\right) \\
& \mathrm{w}=\frac{1}{10} \cdot \frac{\phi}{2 \cdot \eta_{\mathrm{b}}-0,75} \cdot \frac{\sigma_{\mathrm{s}}}{\mathrm{E}_{\mathrm{s}}} \cdot \frac{3 \sigma_{\mathrm{s}}}{\mathrm{f}_{\mathrm{tk}}}
\end{aligned}
$$

Onde: $\quad \phi$ - diâmetro das barras de aço, em mm;

$\eta_{\mathrm{b}}$ - coeficiente de conformação superficial do aço, cujo valor pode ser obtido na NBR-7480 (1985);

$\sigma_{\mathrm{s}}$ - tensão de tração na armadura em serviço:

$$
\sigma_{\mathrm{s}}=\frac{\mathrm{M}_{\mathrm{d}, \text { freq }}}{\mathrm{Z} \cdot \mathrm{A}_{\mathrm{s}}}
$$

$\mathrm{M}_{\mathrm{d}, \text { freq }}$ - momento fletor em serviço;

$\mathrm{z}$ - braço de alavanca no estádio II, simplificadamente podendo ser admitido 0,85.d, onde d é a altura útil da laje;

$\mathrm{A}_{\mathrm{s}}$ - área de armadura tracionada;

$\rho_{\mathrm{r}}$ - taxa geométrica de armadura, com 


$$
\rho_{\mathrm{r}}=\frac{\mathrm{A}_{\mathrm{s}}}{\mathrm{A}_{\mathrm{cr}}}
$$

$\mathrm{A}_{\mathrm{cr}}$ - área de envolvimento das barras da armadura;

$\mathrm{E}_{\mathrm{s}}$ - módulo de elasticidade longitudinal do aço (210 GPa);

$\mathrm{f}_{\mathrm{tk}}$ - resistência característica à tração do concreto.

De acordo com o anexo da NBR-7197 (1989), o valor de $A_{c r}$ deve ser constituído por retângulos cujos lados não distam mais que $7,5 \phi$ do centro do elemento da armadura.

$\mathrm{Na}$ capa de concreto deve ser colocada uma armadura de distribuição (figura 2.7) que, de acordo com a norma espanhola EF-96 (1997), tem por finalidade promover a solidarização entre as vigotas pré-moldadas, fazer a distribuição transversal de cargas localizadas (concentradas ou lineares), promover a distribuição da fissuração provocada pela retração e variações de temperatura, fornecer resistência no plano da laje para a distribuição das ações horizontais, propiciando um comportamento mais efetivo de diafragma, e assegurar uma resistência extra na ocorrência de carregamentos excepcionais.

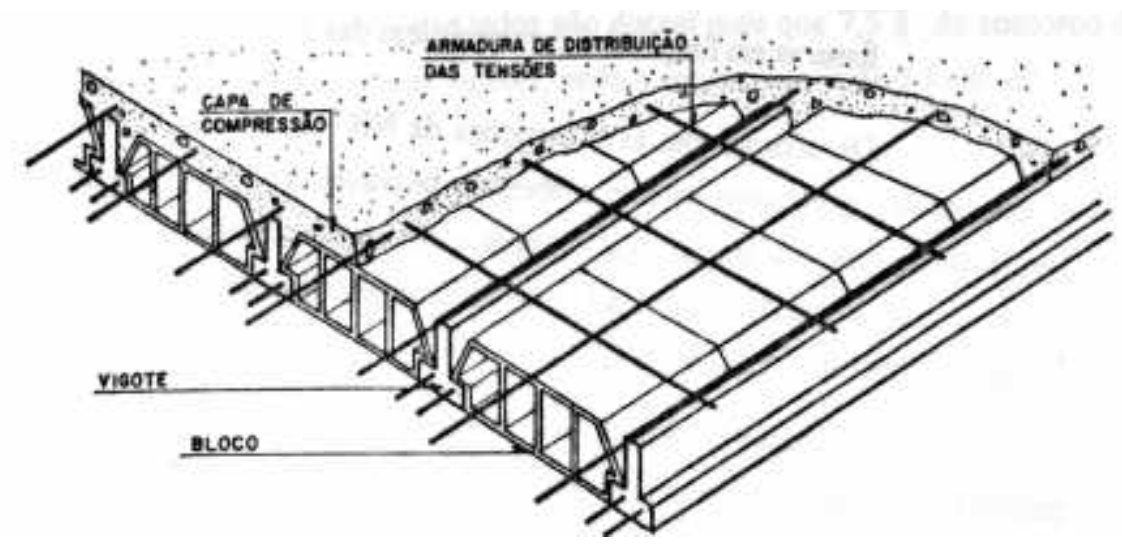

FIGURA 2.7 - Armadura de distribuição [Di PIETRO (1993)]

A norma espanhola EF-96 (1997) prescreve que a armadura de distribuição deverá ser composta por barras de aço com diâmetro mínimo de 4,0 mm posicionados nas duas direções da laje e com espaçamentos inferiores a $35 \mathrm{~cm}$. A área de armadura de distribuição, $\mathrm{em} \mathrm{cm}^{2} / \mathrm{m}$, será: 
1. Na direção perpendicular às nervuras

$$
\mathrm{A}_{\mathrm{dist}, 1}=\frac{5 \cdot \mathrm{h}_{\mathrm{f}}}{\mathrm{f}_{\mathrm{yd}}}
$$

2. Na direção paralela às nervuras

$$
\mathrm{A}_{\mathrm{dist}, 2}=\frac{2,5 \cdot \mathrm{h}_{\mathrm{f}}}{\mathrm{f}_{\mathrm{yd}}}
$$

Onde: $\quad \mathrm{h}_{\mathrm{f}}$ : espessura da capa de concreto, em $\mathrm{cm}$;

$\mathrm{f}_{\mathrm{yd}}$ : Resistência de cálculo do aço, em $\mathrm{kN} / \mathrm{cm}^{2}$.

\subsection{Consideração da redistribuição dos esforços}

A análise linear seguida por uma limitada redistribuição de momentos fletores tem sido introduzida e comumente utilizada em projetos. Dentre os vários benefícios que se tem ao se projetar utilizando redistribuição de momentos fletores, o CEB (1998) lista, dentre outros, os seguintes:

- a transferência de esforços solicitantes para as áreas com tensões mais baixas;

- menor taxa de armadura localizada nas áreas de momentos fletores negativos, portanto, tensões reduzidas na região comprimida da seção;

- redução do congestionamento de barras de aço sobre os apoios de lajes contínuas e assim melhorando as condições de concretagem nestas áreas críticas;

- maior liberdade no detalhamento da armadura.

Muitas normas adotam critérios próprios para limitar a redistribuição dos momentos fletores. A norma brasileira NBR-6118 (1978) e a norma espanhola EF-96 (1997) são freqüentemente utilizadas por projetistas na realização do cálculo plástico (cálculo com momentos fletores redistribuídos) das lajes com vigotas treliçadas. Alguns projetistas consideram a redistribuição plástica como função do momento resistente da seção submetida ao momento fletor negativo, impondo no dimensionamento um valor limite para a linha neutra. A seguir são mostrados com maiores detalhes os critérios descritos acima. 


\subsubsection{Recomendações da norma brasileira NBR-6118 (1978)}

A NBR-6118 (1978) não trata da redistribuição dos esforços de forma específica para as lajes nervuradas. Entretanto, muitos projetistas baseiam-se no item 3.2.2.3 que permite calcular os momentos fletores em vigas em regime elastoplástico alterando-se unicamente a posição da linha de fecho, determinada no regime elástico, por meio de uma redução nos momentos fletores sobre os apoios de no máximo $15 \%$. Sempre deve ser verificado se não é ultrapassada a capacidade de deformação angular do concreto armado no trecho plastificado.

O critério adotado pela norma brasileira é muito limitado pois deixa de considerar diversos fatores que afetam a redistribuição dos esforços, tais como os encontrados no CEB (1998): o sistema estático, tipos de carregamento, ductilidade do concreto armado, taxa de armadura e forma da seção transversal, entre outros.

\subsubsection{Recomendações da norma espanhola EF-96 (1997)}

De acordo com a norma espanhola EF-96 (1997), no cálculo dos esforços em lajes com vigotas pré-moldadas pode ser considerada uma redistribuição plástica dos momentos fletores correspondente a $15 \%$ ou, no máximo, a redistribuição que resulta ao se igualar os máximos momentos fletores negativos e positivos em cada tramo. A redistribuição máxima admitida para as lajes contínuas pode ser obtida a partir do seguinte procedimento:

a) Momentos fletores positivos: igualar os valores do máximo momento fletor positivo e dos momentos fletores nos apoios para cada tramo interno e valor do momento fletor máximo positivo e do momento fletor do apoio para o tramo extremo (figura 2.8-a).

b) Momentos fletores negativos: se adotaria, no mínimo, a linha de fechamento formada pelos máximos momentos fletores negativos nos apoios internos encontrados em a) e para os apoios extremos, considerar um momento fletor negativo com valor igual a quarta parte do máximo momento fletor positivo deste vão (figura 2.8-b). 
c) Balanços: deve-se considerar o máximo momento fletor que resulta ao se considerar a carga atuante no balanço ou a quarta parte do momento fletor positivo do vão adjacente (figura 2.8-b).

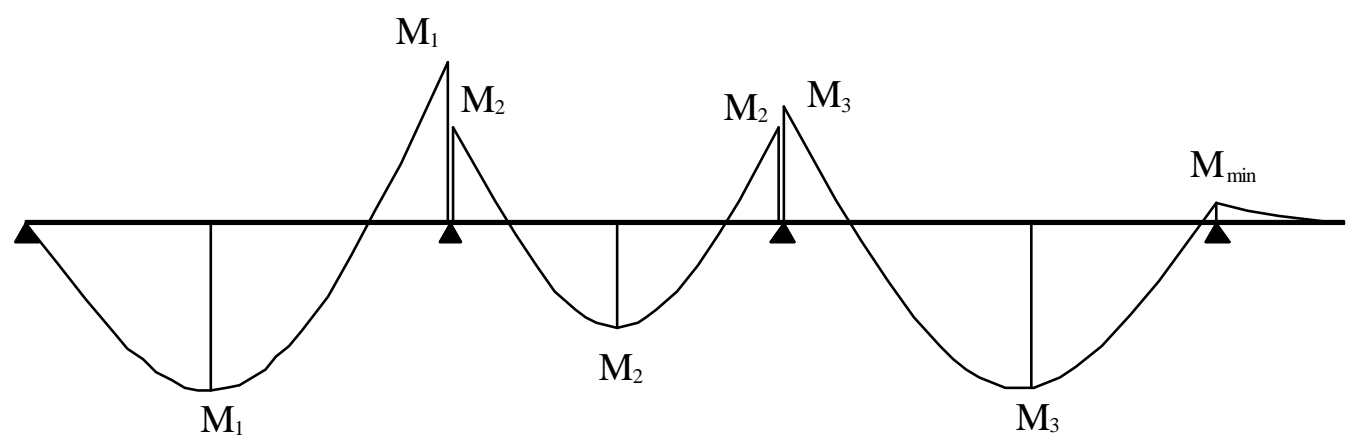

a) Diagrama para momentos fletores positivos

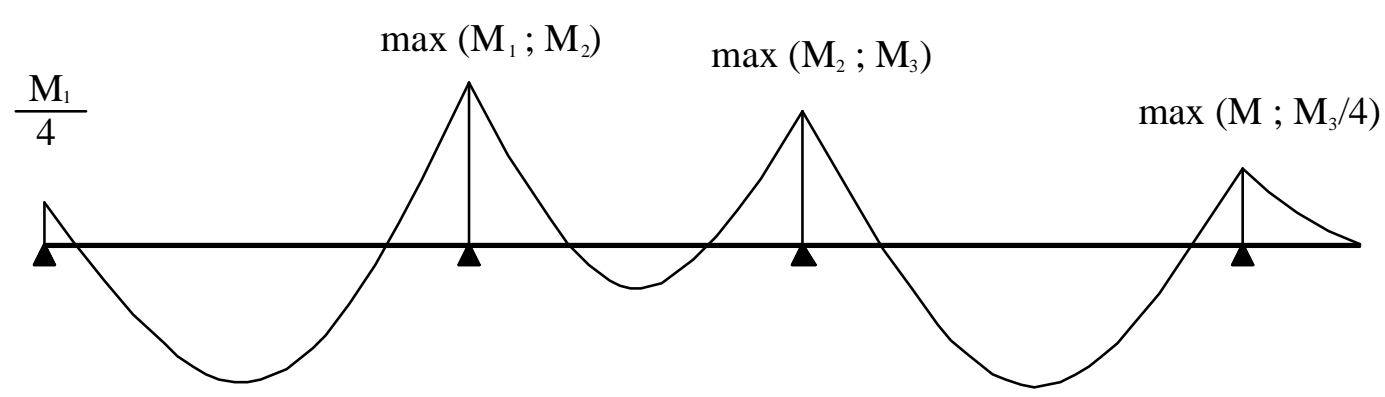

b) Diagrama para momentos fletores negativos

FIGURA 2.8- Diagramas dos momentos de acordo com a norma espanhola EF-96 (1997)

Nos apoios onde não há continuidade será considerado um momento fletor negativo não inferior a 1/4 do máximo momento fletor positivo do tramo.

Esta norma observa que todos os vãos deverão resistir, no mínimo, a um momento fletor positivo igual a $1 / 2$ do seu momento fletor isostático.

\subsubsection{Recomendações práticas para consideração da continuidade}

Na prática usual do projeto de uma laje contínua formada por elementos pré-moldados com armação treliçada, não se costuma adotar no dimensionamento os momentos fletores negativos obtidos a partir da análise linear. Isto decorre, conforme já foi comentado, do fato dos momentos fletores negativos serem da mesma ordem de grandeza dos momentos fletores positivos e que a resistência da seção $\mathrm{T}$ a 
momentos fletores negativos é muito inferior à resistência a momentos fletores positivos.

O procedimento usualmente adotado por vários projetistas para resolver o problema da continuidade consiste em considerar o valor do momento fletor negativo igual ao máximo momento fletor que a seção resiste. Para tanto, é necessário arbitrar a posição da linha neutra com valores não superiores a linha neutra que corresponde ao limite entre os domínios 3 e 4 . A situação mais favorável é aquela em que o cálculo é realizado entre os domínios 3 e 4, pois os dois materiais atingem sua máxima capacidade resistente e são melhor aproveitados.

Em seguida, a laje é calculada como se fosse simplesmente apoiada com momentos aplicados nas extremidades dos vãos de valores iguais ao momento resistente da seção (figura 2.9).

Neste caso, deve-se ter cuidado para não impor momentos fletores negativos superiores àqueles que seriam obtidos a partir de uma análise linear com rigidez constante.

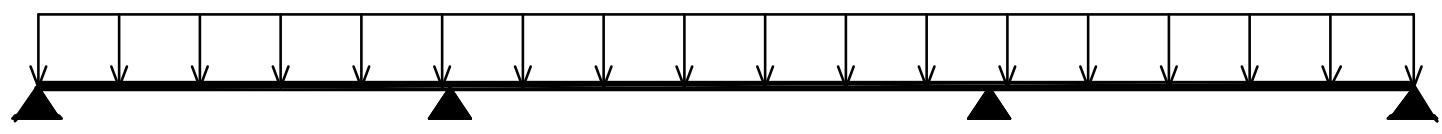

Situação inicial
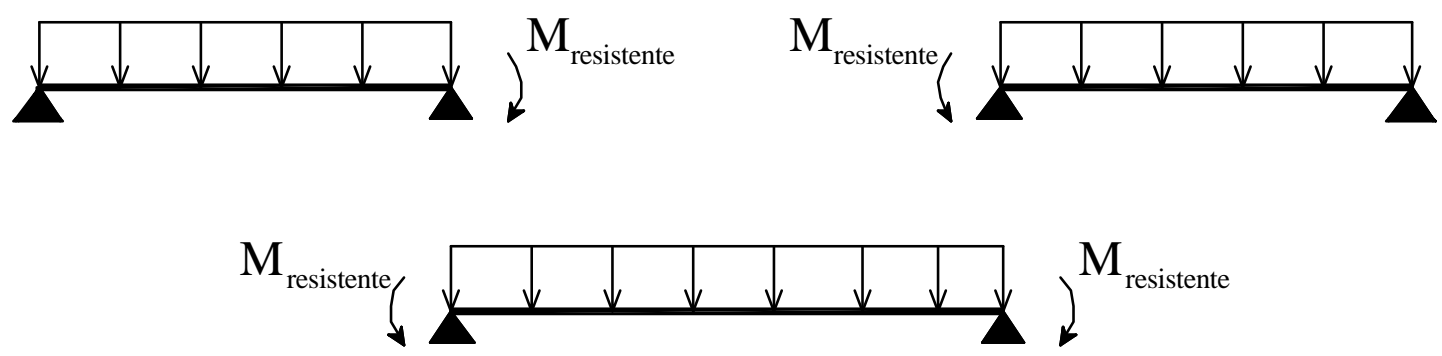

Prática usual no cálculo plástico

FIGURA 2.9 - Considerações práticas para redistribuição dos esforços 


\section{ANÁLISES TEÓRICAS}

\subsection{Considerações iniciais}

Para as análises teóricas estabeleceu-se uma seqüência de procedimentos que pode ser sucintamente listada como segue.

- Apresentação dos fundamentos para a consideração da não-linearidade física do concreto a partir da relação de momento $x$ curvatura do código modelo CEB-90 (1991) e a técnica do carregamento incremental.

- Análise do comportamento não-linear de estruturas unidirecionais e contínuas de concreto armado.

- Breve discussão sobre a capacidade de rotação das rótulas plásticas em estruturas lineares de concreto armado.

- Consideração da capacidade de rotação plástica adotada neste trabalho.

- Apresentação simplificada de como foram realizadas as modelagens numéricas utilizando o programa computacional ANSYS ${ }^{\circledR}$. 


\subsection{Fundamentos para a consideração da não-linearidade física do concreto}

Para que a avaliação dos deslocamentos e esforços solicitantes numa estrutura de concreto armado possa estar mais próxima da realidade é necessária uma devida estimativa dos parâmetros de rigidez. Esta avaliação se torna complexa pelo fato de parte do elemento estrutural trabalhar no estádio I, parte no estádio II e em estruturas hiperestáticas, alguns trechos podem estar no estádio III.

Nos últimos anos, vários modelos não-lineares têm sido desenvolvidos de modo a melhor descrever o comportamento das estruturas de concreto. Dentre os diversos modelos para se considerar a não-linearidade física do concreto, destacamse as relações momento $x$ curvatura usadas com o intuito de se evitar a integração das tensões normais no domínio da seção transversal. Com isto, o trabalho computacional se torna mais simples e ainda permite a utilização de um número razoável de elementos sem empregar uma grande quantidade de memória.

CÂMARA (1988) salienta que a análise não-linear a partir do uso da relação momento $x$ curvatura apresenta bons resultados desde que o modelo se encontre suficientemente testado.

\subsubsection{O Diagrama momento $x$ curvatura segundo o CEB-90 (1991)}

O estado de deformação das seções transversais de concreto armado submetidas à flexão simples fica definido pela relação constitutiva expressa em termos do momento $x$ curvatura. A curvatura média de uma seção é dada pela seguinte expressão:

$$
\begin{aligned}
& \frac{1}{\mathrm{r}}=\frac{\varepsilon_{\mathrm{sm}}-\varepsilon_{\mathrm{cm}}}{\mathrm{d}} \\
& \text { onde: } \quad \begin{array}{l}
\varepsilon_{\mathrm{sm}}-\text { deformação específica média do aço; } \\
\varepsilon_{\mathrm{cm}}-\text { deformação específica média do concreto na borda mais } \\
\text { comprimida. }
\end{array}
\end{aligned}
$$


Como nem sempre é fácil obter esta relação, pode-se recorrer a outras expressões de modo a se obter a equação constitutiva. De maneira simplificada, pode-se relacionar o momento fletor atuante $(\mathrm{M})$ com a curvatura (1/r) a partir do modelo que considera a flexão simples num trecho de peça em que a seção está contida. A partir do diagrama momento $x$ curvatura, define-se a rigidez média à flexão, dado por:

$$
\frac{\mathrm{M}}{\mathrm{E}_{\mathrm{c}} \mathrm{I}}=\frac{1}{\mathrm{r}}
$$

onde: $\quad \mathrm{E}_{\mathrm{c}}-$ módulo de elasticidade do concreto

I - momento de inércia da seção considerada

De acordo com o CEB-90 (1991), o módulo de elasticidade do concreto aos 28 dias de idade $\left(\mathrm{E}_{\mathrm{c}}\right)$ pode ser estimado com a seguinte expressão

$$
\mathrm{E}_{\mathrm{c}}=21500 \cdot \sqrt[3]{\frac{\mathrm{f}_{\mathrm{cm}}}{10}} \quad(\mathrm{MPa}) ; \quad \mathrm{E}_{\mathrm{cs}}=0,85 \cdot \mathrm{E}_{\mathrm{c}}
$$

onde: $\quad \mathrm{f}_{\mathrm{cm}}=\mathrm{f}_{\mathrm{ck}}+8$ : resistência média à compressão;

$\mathrm{f}_{\mathrm{ck}}=$ resistência característica à compressão do concreto aos 28 dias;

$\mathrm{E}_{\mathrm{cs}}=$ módulo de elasticidade reduzido (secante), no qual é considerado o início da plastificação do concreto.

Na figura 3.1 é mostrada a relação momento $x$ curvatura definida no CEB-90 (1991) para uma seção de concreto armado submetida à flexão simples. Observa-se nesta figura que a curvatura média é alterada para um valor $M_{r} \cdot \sqrt{\beta_{b}}$ anterior ao momento de fissuração $\mathrm{M}_{\mathrm{r}}$, onde $\beta_{\mathrm{b}}$ é um coeficiente que leva em conta a forma de carregamento e o tipo de armadura.

Para um momento fletor superior a $M_{r} \cdot \sqrt{\beta_{b}}$ ocorre uma sensível diminuição na rigidez à flexão, embora não exista, a princípio, sinal de escoamento do aço ou plastificação do concreto comprimido. Este trecho do diagrama corresponde ao estádio II.

O terceiro trecho ocorre quando o aço tracionado escoa ou quando o concreto comprimido plastifica, provocando uma sensível variação na rigidez do trecho. Nesta situação as deformações começam a ser grandes pelo menos na região 
próxima a seção em análise. $\mathrm{O}$ momento fletor de escoamento ou plastificação $\left(\mathrm{M}_{\mathrm{y}}\right)$ e o momento fletor último $\left(\mathrm{M}_{\mathrm{u}}\right)$ limitam este trecho do diagrama.

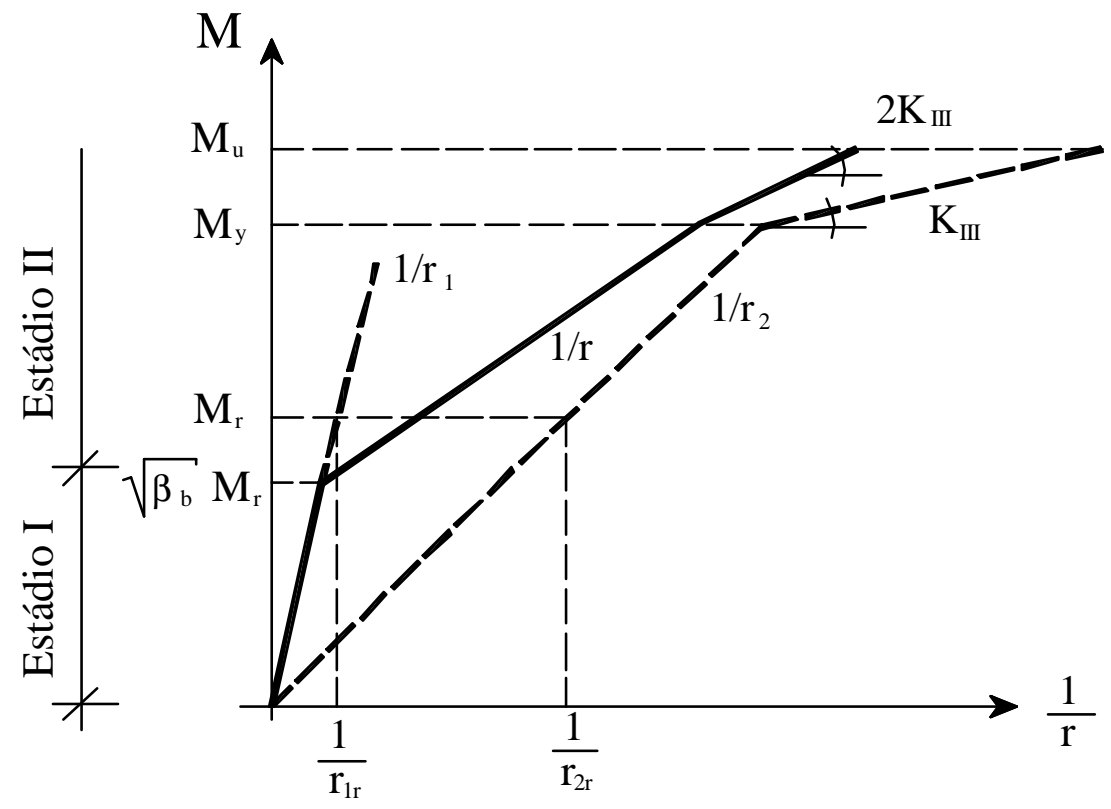

FIGURA 3.1 - Relação Momento $x$ Curvatura segundo o CEB-90 (1991)

O CEB-90 (1991) fornece as seguintes indicações para a relação momento $x$ curvatura:

\section{$\underline{\text { Para o estádio I }}$}

$$
\begin{aligned}
& \frac{1}{\mathrm{r}}=\frac{1}{\mathrm{r}_{1}}=\frac{\sqrt{\beta_{\mathrm{b}}} \cdot \mathrm{M}_{\mathrm{r}}}{\mathrm{E}_{\mathrm{c}} \cdot \mathrm{I}_{1}} \\
& \text { onde: } \quad \beta_{\mathrm{b}}>\beta_{1} \cdot \beta_{2}
\end{aligned}
$$

\section{$\underline{\text { Para o estádio II }}$}

$$
\begin{aligned}
\operatorname{para} \sqrt{\beta_{\mathrm{b}}} \cdot \mathrm{M}_{\mathrm{r}}<\mathrm{M} \leq \mathrm{M}_{\mathrm{y}} \\
\qquad \frac{1}{\mathrm{r}}=\frac{1}{\mathrm{r}_{2}}-\frac{1}{\mathrm{r}_{\mathrm{ts}}}=\frac{1}{\mathrm{r}_{2}}-\left(\frac{1}{\mathrm{r}_{2 \mathrm{r}}}-\frac{1}{\mathrm{r}_{1 \mathrm{r}}}\right) \cdot \beta_{\mathrm{b}} \cdot\left(\frac{\mathrm{M}_{\mathrm{r}}}{\mathrm{M}}\right)
\end{aligned}
$$

e para $\mathrm{M}>\mathrm{M}_{\mathrm{y}}$

$$
\frac{1}{\mathrm{r}}=\frac{1}{\mathrm{r}_{\mathrm{y}}}-\left(\frac{1}{\mathrm{r}_{2 \mathrm{r}}}-\frac{1}{\mathrm{r}_{1 \mathrm{r}}}\right) \cdot \beta_{\mathrm{b}} \cdot\left(\frac{\mathrm{M}_{\mathrm{r}}}{\mathrm{M}_{\mathrm{y}}}\right)+\frac{\left(\mathrm{M}-\mathrm{M}_{\mathrm{y}}\right)}{2 \cdot \mathrm{K}_{\mathrm{III}}}
$$

com 


$$
\mathrm{K}_{\mathrm{III}}=\frac{\mathrm{M}_{\mathrm{u}}-\mathrm{M}_{\mathrm{y}}}{\frac{1}{\mathrm{r}_{\mathrm{u}}}-\frac{1}{\mathrm{r}_{\mathrm{y}}}}
$$

onde: $\quad \mathrm{M}-$ momento fletor na seção ou trecho analisado;

$\mathrm{M}_{\mathrm{y}}$ - momento que inicia o escoamento da armadura tracionada ou plastificação do concreto comprimido;

$\mathrm{M}_{\mathrm{r}}$ - momento de fissuração da seção ou trecho analisado;

$\mathrm{M}_{\mathrm{u}}$ - momento último da seção;

$1 / \mathrm{r}_{\mathrm{y}}$ - curvatura correspondente ao momento $\mathrm{M}_{\mathrm{y}}$;

$1 / r_{u}$ - curvatura correspondente ao momento $M_{u}$;

$1 / \mathrm{r}_{1 \mathrm{r}}$ - curvatura correspondente ao estádio I com atuação do momento $\mathrm{M}_{\mathrm{r}}$;

$1 / \mathrm{r}_{2}$ - curvatura correspondente ao estádio II puro com atuação do momento M;

$1 / \mathrm{r}_{2 \mathrm{r}}$ - curvatura correspondente ao estádio II puro com atuação do momento $\mathrm{M}_{\mathrm{r}}$;

$1 / \mathrm{r}_{\mathrm{ts}}$ - contribuição do concreto tracionado entre fissuras ("tension stiffening"), expresso por:

$$
\frac{1}{\mathrm{r}_{\mathrm{ts}}}=\left(\frac{1}{\mathrm{r}_{2 \mathrm{r}}}-\frac{1}{\mathrm{r}_{1 \mathrm{r}}}\right) \cdot \beta_{\mathrm{b}} \cdot\left(\frac{\mathrm{M}_{\mathrm{r}}}{\mathrm{M}}\right) ;
$$

$\beta_{\mathrm{b}}$ - coeficiente que leva em conta o tipo de armadura e de carregamento;

$\beta_{1}$ - 0,5 para barras de má aderência e 1,0 caso contrário;

$\beta_{2}-0,5$ para cargas repetitivas e 0,8 para o primeiro carregamento.

Para determinar cada trecho do diagrama momento $x$ curvatura, faz-se necessário definir o momento de fissuração $\left(\mathrm{M}_{\mathrm{r}}\right)$, o momento correspondente ao início de escoamento da armadura ou plastificação do concreto $\left(\mathrm{M}_{\mathrm{y}}\right)$ e o valor de momento último $\left(\mathrm{M}_{\mathrm{u}}\right)$.

Conforme pode ser encontrado em LEONHARDT (1982) e NBR-7197 (1989), o valor do momento de fissuração pode ser determinado pela seguinte expressão:

$$
\mathrm{M}_{\mathrm{r}}=\mathrm{W}_{1} \cdot \mathrm{f}_{\mathrm{ct}}
$$

com: $\quad \mathrm{W}_{1}-$ módulo de resistência no estádio I considerando a armadura; 
$\mathrm{f}_{\mathrm{ct}}$ - resistência média à tração por flexão do concreto.

No anexo da NBR-7197 (1989) é disposto que, na verificação do estado limite de formação de fissuras, a resistência à tração na flexão deve ser admitida igual a 1,2 vez o valor da sua resistência à tração axial para vigas de seção $\mathrm{T}$ e 1,5 vez a resistência à tração para vigas com seção retangular. Na ausência de resultados experimentais da resistência à tração axial do concreto, o CEB-90 (1991) permite usar a seguinte expressão:

$$
\mathrm{f}_{\mathrm{ctm}}=1,4 \cdot\left(\frac{\mathrm{f}_{\mathrm{ck}}}{10}\right)^{\frac{2}{3}}
$$

onde: $\quad \mathrm{f}_{\mathrm{ctm}}-$ resistência média à tração axial do concreto em MPa.

O valor do momento fletor último pode ser facilmente encontrado utilizando-se os preceitos da NBR-6118 (1978). Escolhendo os valores limites de deformação para o concreto e aço, basta resolver um problema de verificação, pois a armadura já está definida e não se conhece de antemão o domínio que representa a solução.

O momento fletor que equivale ao início do escoamento da armadura tracionada ou o momento fletor para que ocorra a plastificação do concreto comprimido é difícil de ser definido e o CEB-90 (1991) evita fazê-lo. Segundo o diagrama tensão-deformação do concreto (figura 3.2-a), o patamar de escoamento ocorre com uma tensão que corresponde a uma deformação de 2,0 \% . Entretanto, com deformações menores observa-se que ocorre uma grande perda de rigidez em função da plastificação do concreto. Portanto, considera-se neste trabalho a deformação que corresponde ao início da plastificação do concreto igual a 1,5\%o.

Para o aço de classe A, conforme mostrado na figura 3.2-b, a tensão de escoamento é igual a $\mathrm{f}_{\mathrm{ym}}$, uma vez que este aço apresenta um patamar de escoamento perfeitamente definido.

Como o aço de classe $B$ não apresenta patamar de escoamento caracterizado, define-se um limite de escoamento convencional sendo a tensão $f_{y m}$ sob a qual, feita a descarga da peça, reste uma deformação plástica de $2 \%$ e alguns ensaios mostraram que até cerca de $0,7 . f_{\mathrm{ym}} \mathrm{o}$ diagrama tensão $x$ deformação permanece linear (figura 3.2-c). Então, este tipo de aço apresenta um comportamento 
semelhante àquele observado no concreto, pois a partir da tensão de 0,7.f $\mathrm{fm}_{\mathrm{ym}}$, começam a surgir deformações plásticas na armadura. Neste trabalho considerou-se como tensão de escoamento do aço de classe $\mathrm{B}$ um valor igual a $0,85 \mathrm{f}_{\mathrm{ym}}$, o que corresponde ao valor médio entre 0,7 e 1,0 de $\mathrm{f}_{\mathrm{ym}}$.

Em todas as verificações em que não se têm os diagramas experimentais de comportamento do aço e concreto, consideram-se os mesmos diagramas propostos para o dimensionamento, utilizando-se valores médios de resistência no lugar dos valores característicos (figura 3.2).

Os valores considerados neste trabalho para a deformação que corresponde ao início de plastificação do concreto $(1,5 \%$ ) e tensão que corresponde ao início do escoamento da armadura tracionada do aço tipo $\mathrm{B}\left(0,85 . \mathrm{f}_{\mathrm{ym}}\right)$ foram analisados por DROPPA JÚNIOR (1999), comparando-os com resultados obtidos em ensaios experimentais realizados em vigas.

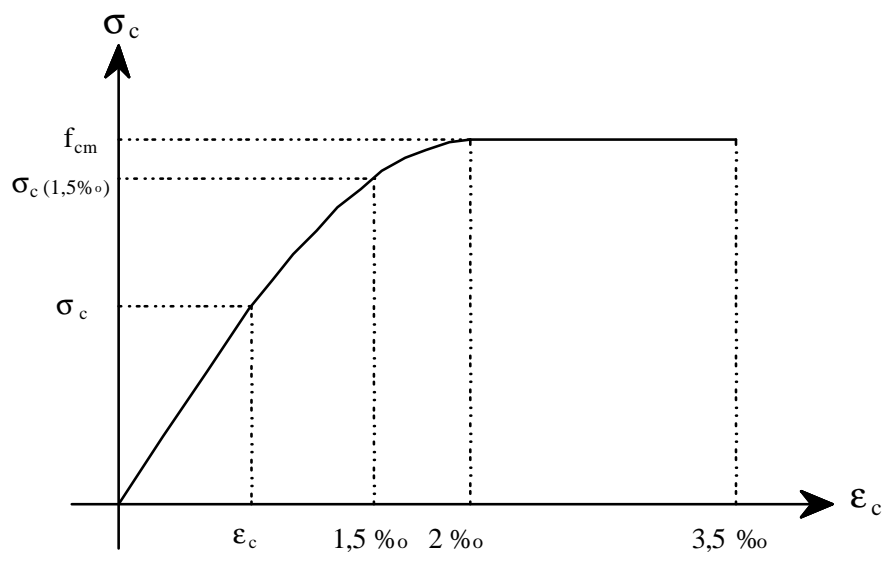

a - Diagrama tensão $x$ deformação do concreto
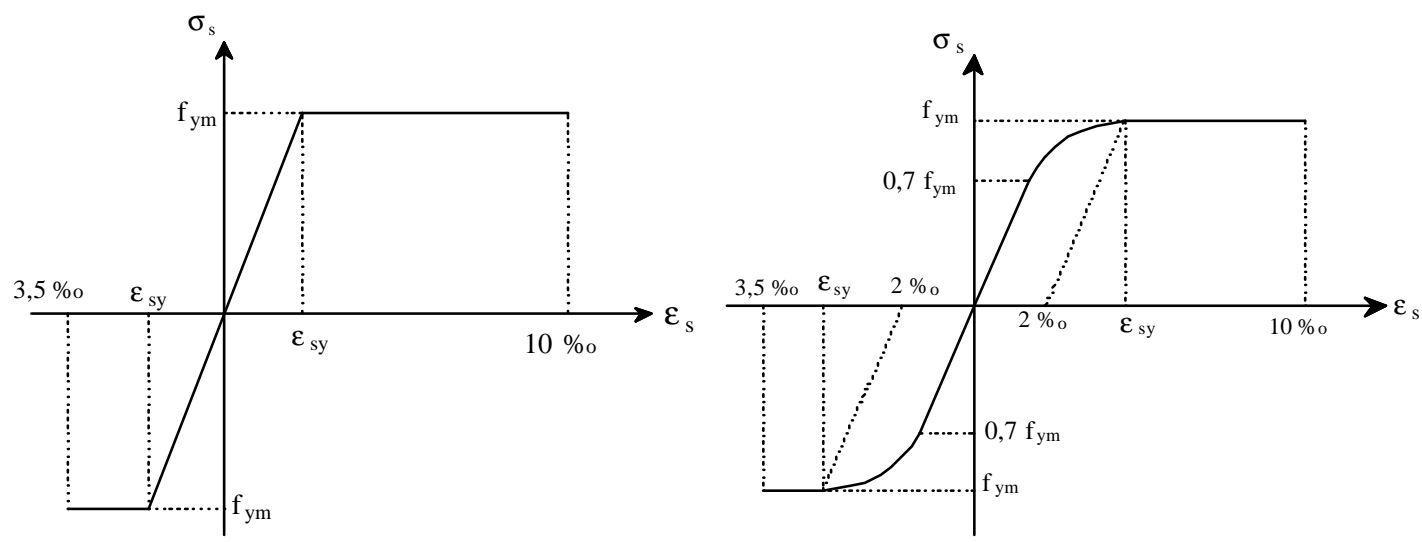

b - Diagrama tensão $x$ deformação do aço tipo A c - Diagrama tensão $x$ deformação do aço tipo B FIGURA 3.2- Diagrama tensão $x$ deformação simplificado dos materiais [NBR-6118(1978)] 


\subsubsection{Carregamento incremental}

Entre as diversas técnicas para se considerar a não-linearidade física de uma estrutura, pode-se destacar a técnica do carregamento incremental. Esta técnica consiste em obter o carregamento total de uma estrutura a partir do somatório de $n$ etapas de cargas e possibilita trabalhar com a rigidez da estrutura atualizada a cada etapa de carga.

Nesta técnica, considera-se que em cada etapa de carga existe linearidade entre esforços e deslocamentos, sendo necessário um número mínimo de etapas. Portanto, o problema não-linear passa a ser resolvido por meio de uma soma de parcelas lineares.

Ao se utilizar a técnica do carregamento incremental, a rigidez de cada elemento em uma dada etapa de carga será decorrente do nível de solicitação da etapa anterior. Segundo CARVALHO (1994), esta aproximação se torna menos significativa à medida que se aumenta o número de etapas de cargas (figura 3.3).

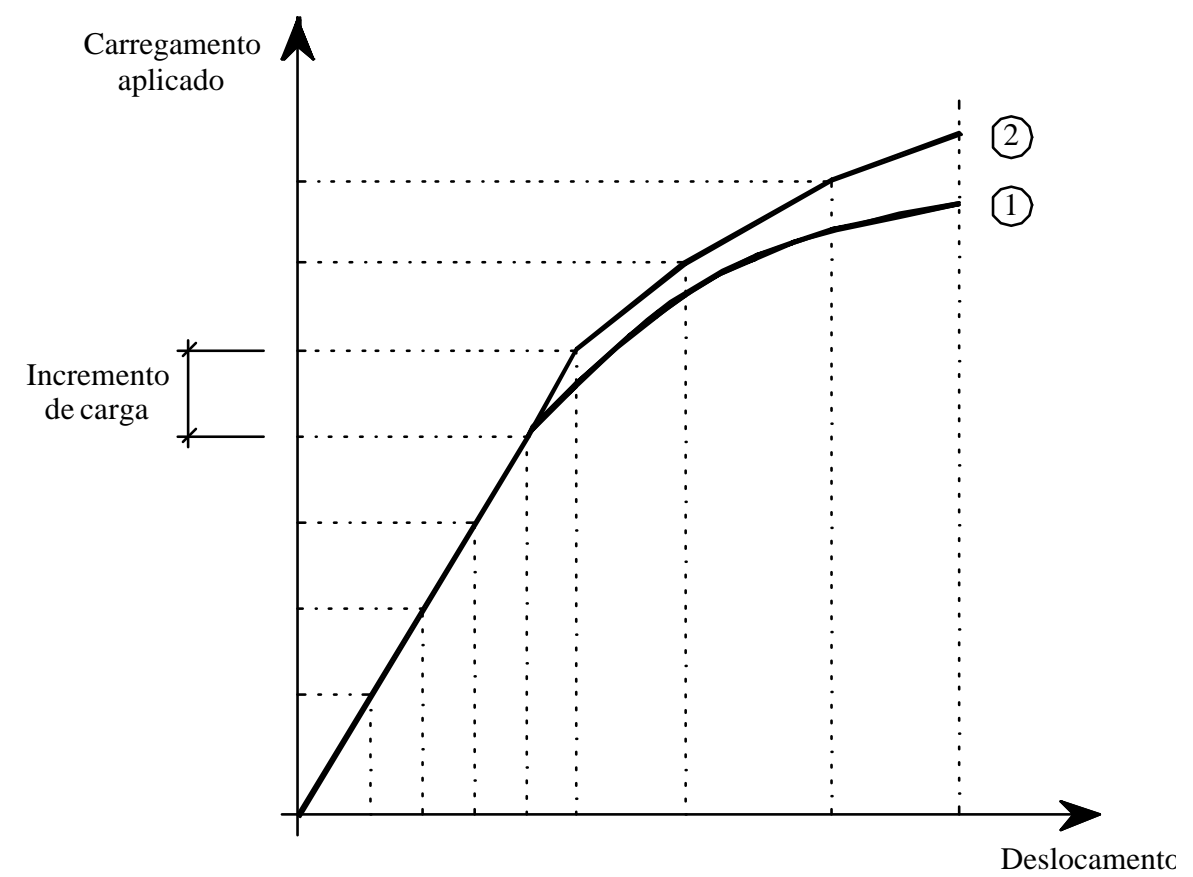

FIGURA 3.3- Diagrama genérico de carga $x$ deslocamento: 1) desenvolvimento real 2) desenvolvimento por etapas lineares [CARVALHO (1994)] 


\subsection{Comportamento de estruturas estaticamente indeterminadas em concreto armado}

Conforme comentado anteriormente, o concreto armado apresenta um comportamento não-linear à medida que o carregamento vai atuando na estrutura. Este comportamento não-linear influencia na distribuição dos esforços solicitantes em estruturas estaticamente indeterminadas.

$\mathrm{Na}$ figura 3.4 é mostrado o comportamento típico de uma estrutura unidirecional estaticamente indeterminada. Nesta figura estão apresentados:

a) o sistema estático;

b) a deformada da estrutura;

c) distribuição dos momentos fletores para um comportamento elásticolinear $(\delta=1,0)$ e o caso quando ocorre uma redistribuição de $50 \%$ dos momentos fletores negativos $(\delta=0,5)$.

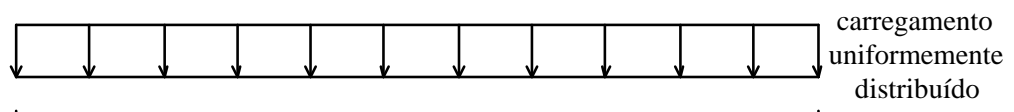

a) -

b) -

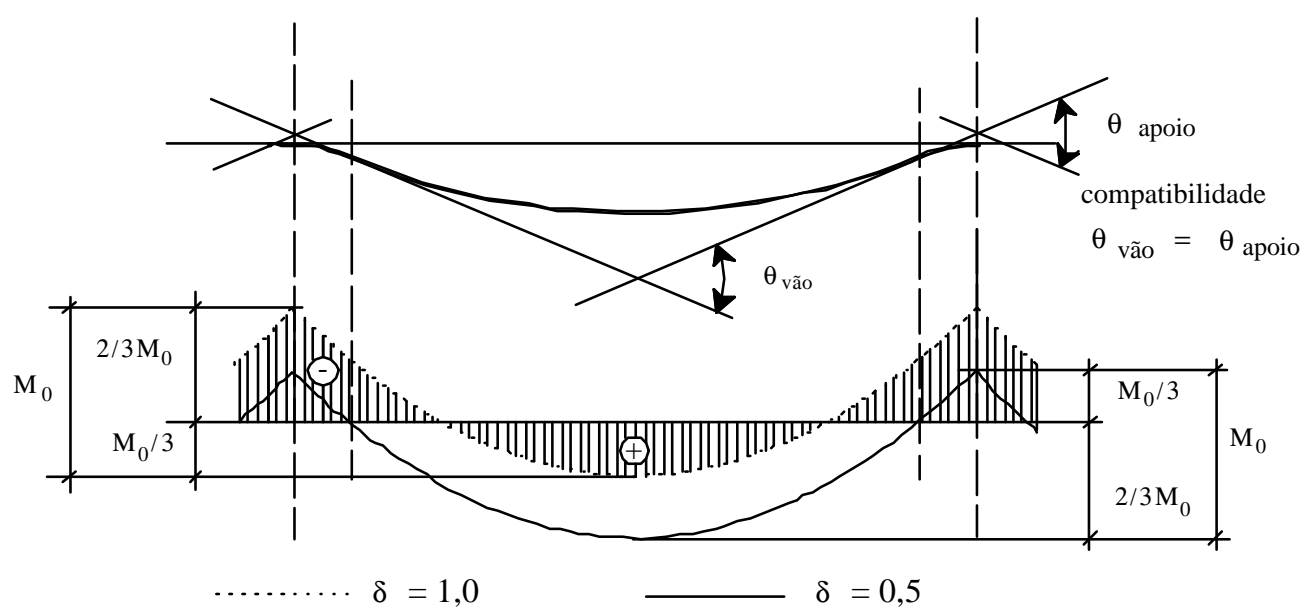

FIGURA 3.4- Estrutura hiperestática unidirecional [CEB (1998)].

O fator de redistribuição $\delta$ é dado por:

$$
\delta=\frac{\mathrm{M}_{\mathrm{ap}}}{\mathrm{M}_{\mathrm{el}}}
$$


onde: $\quad \mathrm{M}_{\mathrm{ap}}-$ momento fletor negativo após a redistribuição;

$\mathrm{M}_{\mathrm{el}}$ - momento fletor negativo calculado de acordo com a teoria da elasticidade.

O grau de redistribuição $\eta$, expresso em porcentagem, é definido por:

$$
\eta=(1-\delta) .100
$$

Na figura 3.5 é mostrada a evolução dos máximos momentos fletores positivos e negativos como função do carregamento aplicado. Para baixos valores de carregamento a estrutura basicamente não apresenta fissuras, ou seja, para um momento fletor abaixo do valor do momento de fissuração a rigidez ao longo do elemento estrutural é praticamente constante (considerando seção transversal retangular com rigidez constante) e os momentos fletores são distribuídos de acordo com a teoria da elasticidade. Para um carregamento uniformemente distribuído, o momento fletor negativo possui intensidade (em valor absoluto) superior ao momento fletor positivo, de modo que a primeira fissura ocorrerá sobre o apoio.

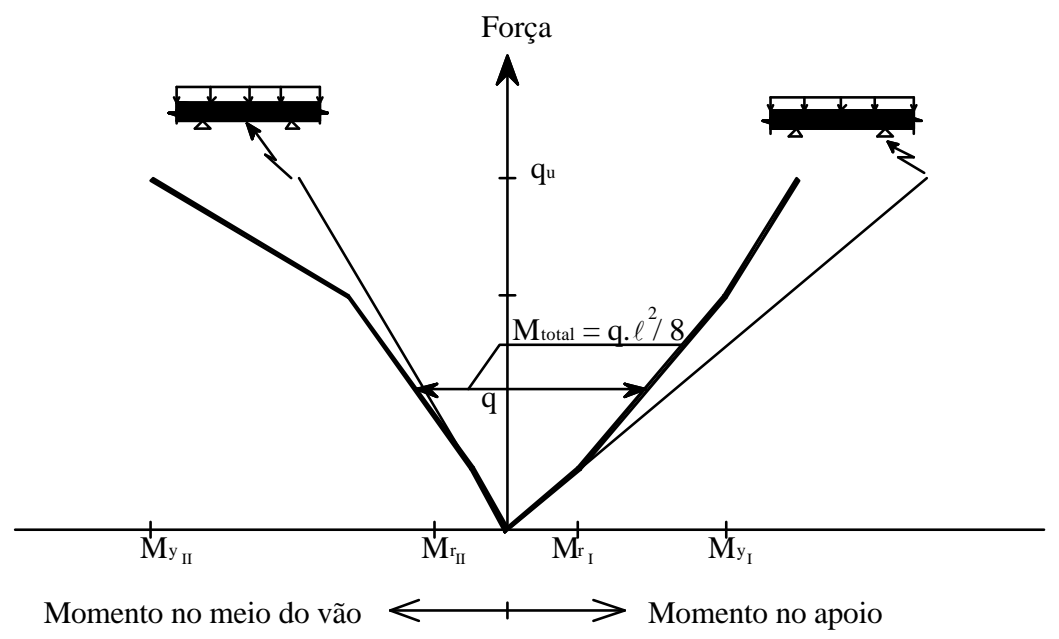

FIGURA 3.5- Evolução dos momentos fletores nas seções críticas $x$ carregamento aplicado [CEB (1998)]

Após atingir o momento de fissuração sobre o apoio $\left(\mathrm{M}_{\mathrm{rI}}\right)$, a diminuição da rigidez à flexão nesta região acarreta em uma menor rapidez no acréscimo do momento fletor negativo à medida que o carregamento vai atuando na estrutura. Como toda estrutura está em equilíbrio, o momento fletor positivo, que nesta fase atua em uma seção mais rígida, começa a crescer com maior velocidade. Portanto, com um novo acréscimo de carga, a seção onde atua o momento fletor positivo 
também irá fissurar, pois será atingido o momento de fissuração para esta seção $\left(\mathrm{M}_{\mathrm{rII}}\right)$.

Para novos acréscimos de carga, a distribuição dos momentos fletores dependerá da distribuição das rigidezes ao longo da estrutura fissurada. Em geral, depois da fissuração a rigidez é proporcional à taxa de armadura existente em cada seção.

A diferença nas rigidezes ao longo do elemento estrutural irá determinar qual das seções críticas alcançará primeiro o momento de escoamento $\left(\mathrm{M}_{\mathrm{yI}}\right)$. Nesta seção, o momento fletor continuará a crescer até atingir o valor do momento fletor último, para o qual uma rótula plástica se desenvolve e a seção começa a girar.

Para desenvolver um mecanismo de colapso com novos acréscimos de carga, o momento fletor na seção onde atua o máximo momento fletor positivo deve atingir o valor de momento último. Para que isto ocorra, a rótula sobre o apoio deve ter uma certa capacidade de rotação, deformando-se até que o máximo momento fletor positivo atinja o valor de momento último.

A rigidez à flexão ao longo do elemento estrutural tem uma influência direta no desenvolvimento das rotações e na capacidade de rotação plástica. Conforme já foi comentado, a rigidez para as seções no estado fissurado depende da taxa de armadura presente nas seções de concreto armado.

Para ilustrar as afirmações acima, comparam-se dois casos nos quais a partir de diferentes arranjos de armaduras, as rigidezes entre o apoio e o meio do vão estão invertidas [CEB (1998)].

Se uma viga contínua com dois vãos de mesmo comprimento, seção retangular e submetida a um carregamento uniformemente distribuído, é dimensionada de acordo com a teoria da elasticidade $(\delta=1,0)$, a rigidez da seção do apoio no estádio II será aproximadamente o dobro da rigidez da seção no meio do vão também no estádio II, ao passo que está relação se torna 0,5 se a mesma estrutura for dimensionada com $\delta=0,5$. A figura 3.6 mostra os diagramas momento $x$ rotação nas seções críticas para os dois casos analisados. 


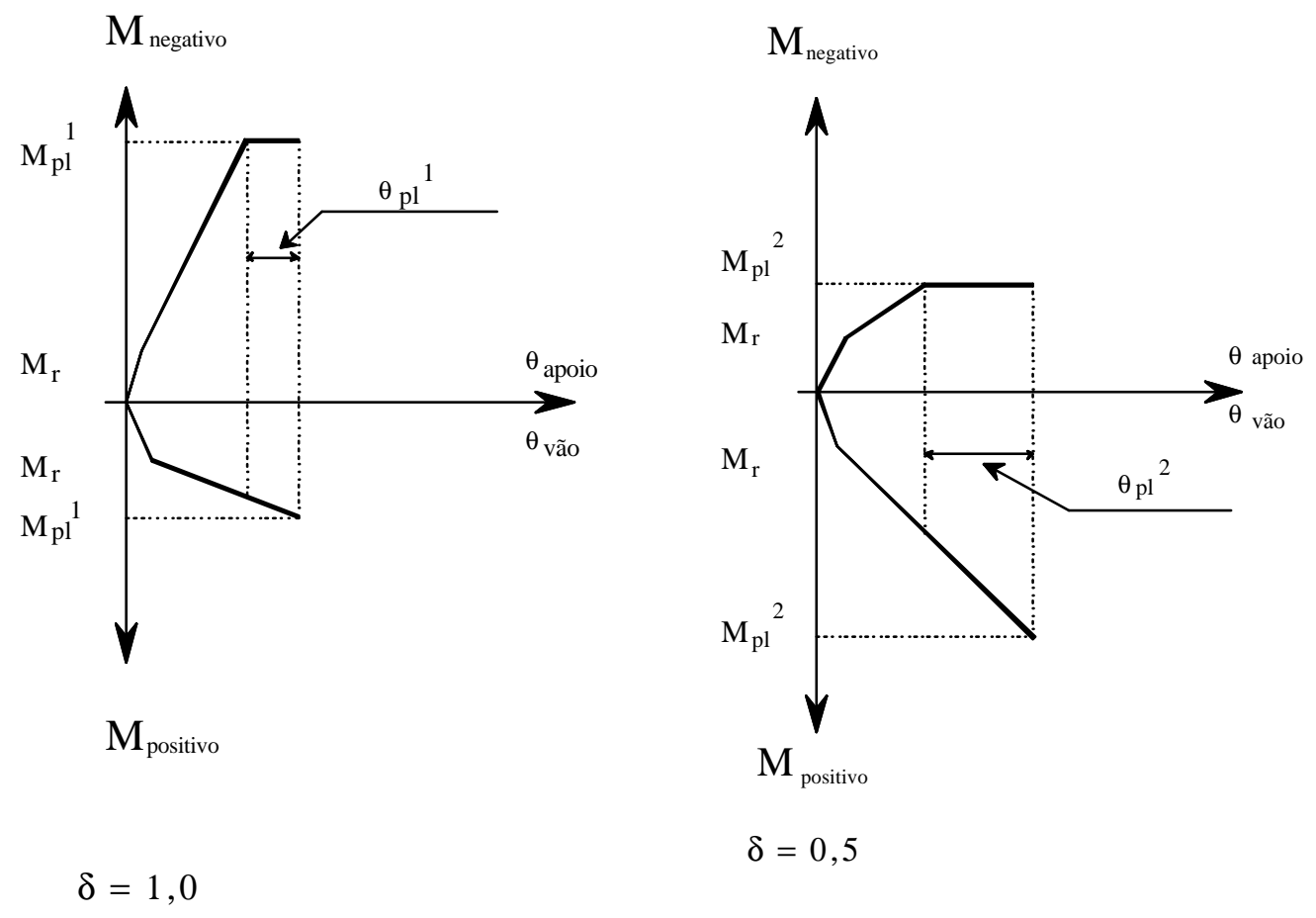

FIGURA 3.6- Diagrama momento $x$ rotação para as seções do meio do vão e apoio intermediário como função do grau de redistribuição. [CEB (1998)].

De acordo com a figura 3.6, na estrutura dimensionada sem redistribuição, ou seja $\delta=1,0$, o momento fletor negativo cresce mais rápido que o momento fletor positivo, atingindo primeiro o escoamento. Para alcançar a carga última (ou carga de ruína), a armadura dimensionada para o momento fletor positivo também deve escoar, sendo necessário uma rotação plástica sobre o apoio $\left(\theta_{\mathrm{pl}}{ }^{1}\right)$, que de acordo com CEB (1998), permite a formação de um mecanismo de colapso.

No segundo caso, em função da menor taxa de armadura sobre a região do apoio, esta armadura escoará a um nível de carregamento inferior ao da armadura no meio do vão. Entretanto, para alcançar a carga de ruína, são necessárias rotações plásticas $\left(\theta_{\mathrm{pl}}{ }^{2}\right)$ muitas maiores que no caso anterior.

\subsection{Considerações sobre a capacidade de rotações plásticas}

Atualmente, várias normas estão prevendo análises não-lineares admitindo a possibilidade da formação de um mecanismo de colapso originado por rótulas plásticas em regiões críticas. Para que o mecanismo de colapso ocorra, faz-se 
necessário que a capacidade de rotação requerida não ultrapasse a capacidade de rotação plástica disponível pelas seções de concreto armado

A capacidade de rotação das rótulas plásticas em estruturas de concreto armado depende de diversos fatores. Para elementos lineares fletidos, o CEB (1998) lista os seguintes:

1- parâmetros dependentes dos materiais constituintes
a. propriedades mecânicas do concreto à tração e compressão
b. resistência e ductilidade do aço
c. aderência da armadura

2- parâmetros dependentes da geometria dos elementos
a. forma da seção transversal
b. taxa geométrica e mecânica da armadura
c. taxa da armadura transversal (confinamento)
d. detalhamento da armadura (diâmetros e arranjos das barras)
e. esbeltez
f. comprimento do elemento

3- parâmetros dependentes do sistema estático e do carregamento
a. sistema estático
b. efeito do cisalhamento
c. tipo de carregamento (gradiente do momento, carregamento axial)
d. aplicação do carregamento
e. duração do carregamento
f. carregamentos repetitivos e cíclicos

A interação dos diversos fatores descritos acima torna ainda mais complexa a definição da capacidade de rotações plásticas em estruturas de concreto armado.

Considerando a grande quantidade e variação dos parâmetros que regem a capacidade de rotação das rótulas plásticas, os resultados obtidos em ensaios experimentais apresentam uma grande dispersão de valores. Mesmo assim, a influência de alguns fatores pode ser confirmada por meio de análises experimentais. 
$\mathrm{Na}$ análise da capacidade de rotação das rótulas plásticas, a profundidade da linha neutra no estado limite último poderia representar bem o efeito das características de tensão $x$ deformação dos materiais, seção transversal e taxa de armadura tracionada e comprimida. Entretanto, de acordo com o CEB (1998) seria uma grande simplificação relacionar a capacidade de rotação somente com a profundidade da linha neutra, uma vez que esta é fortemente influenciada pelas hipóteses de cálculo na ruína.

De acordo com estudos teóricos e experimentais, dependendo da magnitude dos esforços de cisalhamento, dois diferentes tipos de rótulas plásticas podem surgir (figura 3.7). A chamada rótula de fissura por flexão que ocorre em regiões onde o momento fletor é predominante (figura 3.7-a), e a rótula de fissura por cisalhamento que ocorre em regiões onde existe momento fletor e uma considerável parcela do esforço cortante atuando (figura 3.7-b).

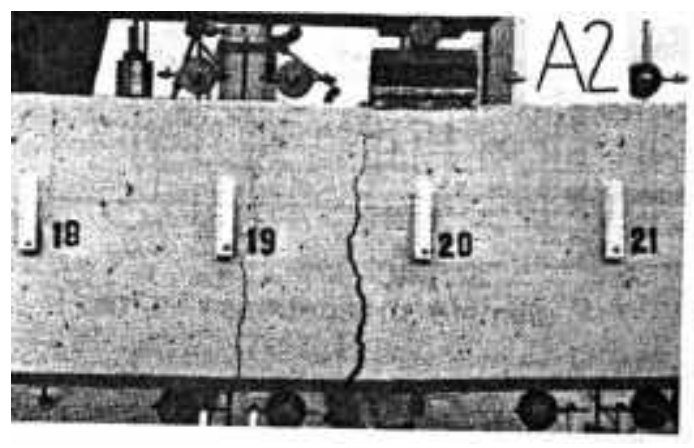

a- Rótula com momento fletor predominante

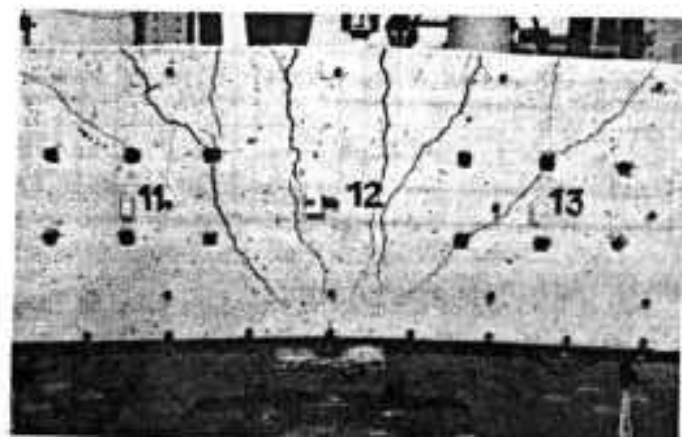

b- Rótula com considerável parcela de esforço cortante

FIGURA 3.7- Tipos de rótulas plásticas [CEB (1998)]

As rótulas originadas por fissuração decorrentes de esforços de flexão concentram as deformações plásticas em poucas fissuras, ocasionando uma capacidade de rotação plástica relativamente baixa. As rótulas de fissuras por cisalhamento apresentam um considerável aumento na capacidade de rotações plásticas decorrentes das fissuras de flexão e cisalhamento. A maior capacidade de rotações plásticas nas seções submetidas ao efeito conjunto dos esforços de flexão e cisalhamento é decorrente do aumento do comprimento da rótula plástica. Nos dois tipos de rótulas que podem surgir, a capacidade de rotação está intimamente relacionada com o valor do esforço solicitante e a taxa de armadura existente para absorver este esforço. 
De acordo com o trabalho de LANGER (1987) ${ }^{1}$ apud CEB (1998), os diferentes tipos de rótulas plásticas foram analisados a partir do efeito da esbeltez dos elementos. Nos seus estudos, foi observado que, à medida que a esbeltez dos modelos era aumentada, as rotações plásticas também aumentavam, mas na zona de transição de um tipo de fissura para outra é encontrada uma significante queda nos valores de rotações plásticas, embora a esbeltez tenha crescido. Portanto, dependendo da esbeltez, diferentes tipos de rótulas plásticas podem se desenvolver e diferentes capacidades de rotações devem ser esperadas.

SIGRIST $(1995)^{2}$ apud CEB (1998) analisa numericamente o efeito da geometria da seção na capacidade de rotações. De acordo com os estudos realizados numa viga caixão e numa laje com seção transversal retangular, quando o dimensionamento é realizado para que a ruptura da armadura prevaleça, a viga caixão apresenta deformações plástica maiores do que a laje com seção transversal retangular. Isto é atribuído, principalmente, ao efeito da relação entre a altura e o espaçamento entre fissuras e a inclinação das bielas de compressão. SIGRIST ainda observou que a capacidade de rotações plásticas não era influenciada somente pela inclinação da biela de compressão, espaçamento e abertura de fissuras, mas também pela localização das fissuras.

Numa estrutura de concreto armado, a ruína pode acontecer por ruptura da armadura tracionada ou por esmagamento do concreto comprimido, neste caso se a capacidade de deformação da armadura é relativamente alta. Quando a ruptura da armadura é a situação crítica de ruína, a ductilidade do elemento estrutural é diretamente governada pela ductilidade do aço e a capacidade de deformação da armadura é completamente utilizada. Se a ruína ocorrer por esmagamento do concreto comprimido, as deformações nas armaduras serão menores que a capacidade de deformação de ruptura da armadura.

1 LANGER, P (1987). Zum nichtlinearen Trag- und Verformungsverhalten von Stahlbetontragwerken unter Last- und Zwangseinwirkung, PhD Thesis, Uiversity of Stuttgart, Institut für Werkstoffe im Bauwesen, pp.214

${ }^{2}$ SIGRIST, V (1995). Zum Verformungsvermögen von Stahlbetonträgern (Rotation Capacity of Structural Concrete Beams), PhD Thesis, Report No. 210, Institute of Structural Engineering, ETH Zürich, pp.159 
De acordo com exposto no parágrafo anterior, na situação em que a ruína se dá por ruptura da armadura tracionada, a capacidade de deformação das seções de concreto armado decresce com a diminuição da área de armadura tracionada uma vez que uma menor quantidade de fissuras aparecerá na região da rótula plástica. Com o aumento da taxa de armadura, a ruína ocorre por esmagamento do concreto comprimido. Isso faz com que o valor de máxima deformação do aço decresça e resulte numa redução da capacidade de rotação plástica. Neste caso, a capacidade de rotação pode ser aumentada por confinamento da zona de compressão. Verificam-se nestes dois casos que, com diferentes valores de taxas de armaduras, diferentes valores de capacidade de rotações podem ser esperadas.

As propriedades dos materiais estão intimamente relacionadas com a forma de ruína do elemento estrutural e, consequentemente, com a capacidade de rotação das rótulas plásticas. A ductilidade da armadura tracionada é uma propriedade de suma importância, principalmente se o colapso do elemento estrutural ocorrer por ruptura da armadura tracionada. A ductilidade do aço pode basicamente ser analisada a partir dos parâmetros de deformação última $\varepsilon_{\mathrm{su}}$ e pela relação entre a resistência à tração e a tensão de início de escoamento do aço $\mathrm{f}_{\mathrm{t}} / \mathrm{f}_{\mathrm{y}}$, chamado aqui de enrijecimento do aço. Quando são usados aços classe A, o comprimento do patamar de escoamento também pode ser tomado como mais um parâmetro na análise da ductilidade do aço.

Por meio de análises teóricas com suportes experimentais, mostra-se que a curvatura e momento últimos de uma seção de concreto armado são independes do enrijecimento da armadura quando a resistência à tração e a deformação última são mantidas constantes e faz-se variar a tensão de início de escoamento. Por outro lado, o comprimento do trecho do elemento estrutural que apresenta deformações plásticas varia com o enrijecimento da armadura, aumentando com o crescimento do mesmo. Agora, se a resistência à tração e o enrijecimento da armadura mantiverem-se constantes e faz-se variar o valor de deformação última, o comprimento da rótula plástica praticamente mantém-se constante. Porém, com o aumento da deformação última do aço, o valor da curvatura última da seção crescerá, aumentando a capacidade de rotação. 
A influência dos parâmetros descritos no parágrafo anterior está diretamente relacionada com a taxa de armadura existente, onde, para baixos valores de taxa de armadura, essa influência é mais significativa. Para altos valores de taxas de armaduras, onde ocorre ruptura por esmagamento do concreto comprimido, a capacidade de rotação irá aumentar com o acréscimo do valor de enrijecimento da armadura por causa do aumento do comprimento da rótula plástica. Entretanto, será quase independente do valor de deformação última, uma vez que $\varepsilon_{\text {su }}$ não é utilizada.

A consideração da aderência entre as barras de aço e o concreto também é um importante parâmetro na análise da capacidade de rotação. De acordo com simulações realizadas por LANGER (1987) apud CEB (1998), ao se analisar modelos idênticos onde nas análises é considerada ou não a contribuição do concreto entre fissuras, pode-se observar que a capacidade de rotação plástica é reduzida em até $50 \%$ devido ao efeito da aderência, se comparado com o caso teórico do aço completamente sem aderência. Este fenômeno tem um papel importante, uma vez que barras lisas ou não apresentam propriedades de aderência diferentes e mesmo com ductilidades semelhantes podem ocasionar grandes diferenças no comportamento da estrutura. Tem-se provado experimentalmente que altos valores de aderência aumentam o efeito do tension stiffening, reduzindo a abertura das fissuras e a rotação da seção fissurada. Com isto, elementos estruturais construídos com barras lisas desenvolvem rotações plásticas muito maiores do que os correspondentes elementos com barras com maiores aderências. Entretanto, deve-se lembrar que uma simples fissura aberta é somente um dos elementos dependentes da aderência contribuindo na capacidade de rotação plástica, devendo ainda ser observados o espaçamento e número de fissuras que estão desenvolvidas na região da rótula.

De acordo com os estudos de LANGER (1989) ${ }^{1}$ e ALCA et al.(1997) ${ }^{2}$ apud CEB (1998), o efeito da mudança da resistência do concreto é quase

${ }^{1}$ LANGER, P. (1989). Einfluß von hochfestem Beton auf die Verdrehfähigkeit plastizierter Tragwerksbereiche, University of Stuttgart, Institut für Werkstoffe im Bauwesen (internal report), pp.19

${ }^{2}$ ALCA et al. (1997). Effect of size on flexural behavior of high-strength concrete beans, ACI Structural Journal, Vol.94, No.1,pp.59-67 
desprezível nas rotações plásticas, para iguais valores da linha neutra dentro de uma série investigada, se o concreto comprimido se apresenta confinado por armadura transversal ou quando é utilizada uma alta taxa de armadura longitudinal de tração.

\subsection{Determinação da força última no modelo teórico}

Nas análises teóricas, o elemento estrutural será submetido ao carregamento incremental até ser atingida a força última. Os critérios adotados na determinação da força última são os seguintes:

I. Verificação da capacidade de rotação das rótulas plásticas.

II. Formação de um mecanismo de colapso.

\subsubsection{Critério da capacidade de rotação das rótulas plásticas}

Este critério verifica se não é excedida a capacidade de rotação das rótulas plásticas nas regiões críticas.

Neste trabalho, a capacidade de rotação plástica será verificada por meio de dois métodos distintos. No primeiro método, a consideração da capacidade de rotação plástica é feita a partir da limitação da curvatura da seção crítica ao valor de curvatura última $1 / \mathrm{r}_{\mathrm{u}}$. O outro método consiste em verificar a capacidade de rotação plástica utilizando o modelo de Darmstadt-Leipizig apresentado no CEB (1998).

Nas modelagens numéricas, à medida que o carregamento incremental vai atuando, são verificadas para cada seção se o momento fletor atinge ou não o valor de momento último. Caso o valor de momento último da seção seja atingido, será formada, nesta seção, uma rótula plástica que apresentará deformações plásticas não superiores à capacidade de rotação plástica de acordo com o método adotado.

A consideração nas análises teóricas que a rótula plástica está concentrada em uma única seção do elemento estrutural é uma simplificação do que ocorre na estrutura real, uma vez que, conforme apresentado no item 3.4 deste trabalho, a rótula plástica numa estrutura real corresponde a um trecho do elemento estrutural. 
A seguir são apresentados com mais detalhes os dois métodos utilizados neste trabalho para a consideração da capacidade de rotação plástica.

a) Limitação da curvatura da seção crítica ao valor de curvatura última

Neste método, a consideração da capacidade de rotação será realizada limitando-se a curvatura em cada seção do elemento estrutural ao valor da curvatura última $1 / \mathrm{r}_{\mathrm{u}}$. Conforme foi comentado anteriormente, a curvatura última é calculada a partir das equações de equilíbrio, de compatibilidade e constitutiva dos materiais seguindo os preceitos da NBR-6118 (1978).

Quando no carregamento incremental do modelo teórico o momento fletor de uma seção atinge $\mathrm{M}_{\mathrm{u}}$, é criada uma rótula plástica e, assim, não é possível obter a curvatura desta seção utilizando a relação momento $x$ curvatura do CEB-90 (1991). A curvatura desta seção será determinada considerando a hipótese que nas suas proximidades a deformada do elemento estrutural é aproximada por um arco de círculo. De acordo com a nomenclatura da figura 3.8, a curvatura pode ser determinada pela seguinte expressão:

$$
\frac{1}{\mathrm{r}}=\frac{2 \cdot \mathrm{a}}{\left(\ell_{\mathrm{e}}\right)^{2}+\mathrm{a}^{2}}
$$

onde:

$$
a=d_{2}-\left(\frac{d_{1}+d_{3}}{2}\right)
$$

$\ell_{\mathrm{e}}-$ tamanho do elemento;

$\mathrm{d}$ - deslocamento nos pontos 1,2 e $3 \mathrm{da}$

figura 3.8 . 


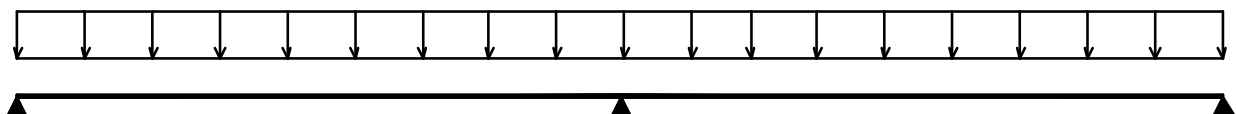

a)

b)

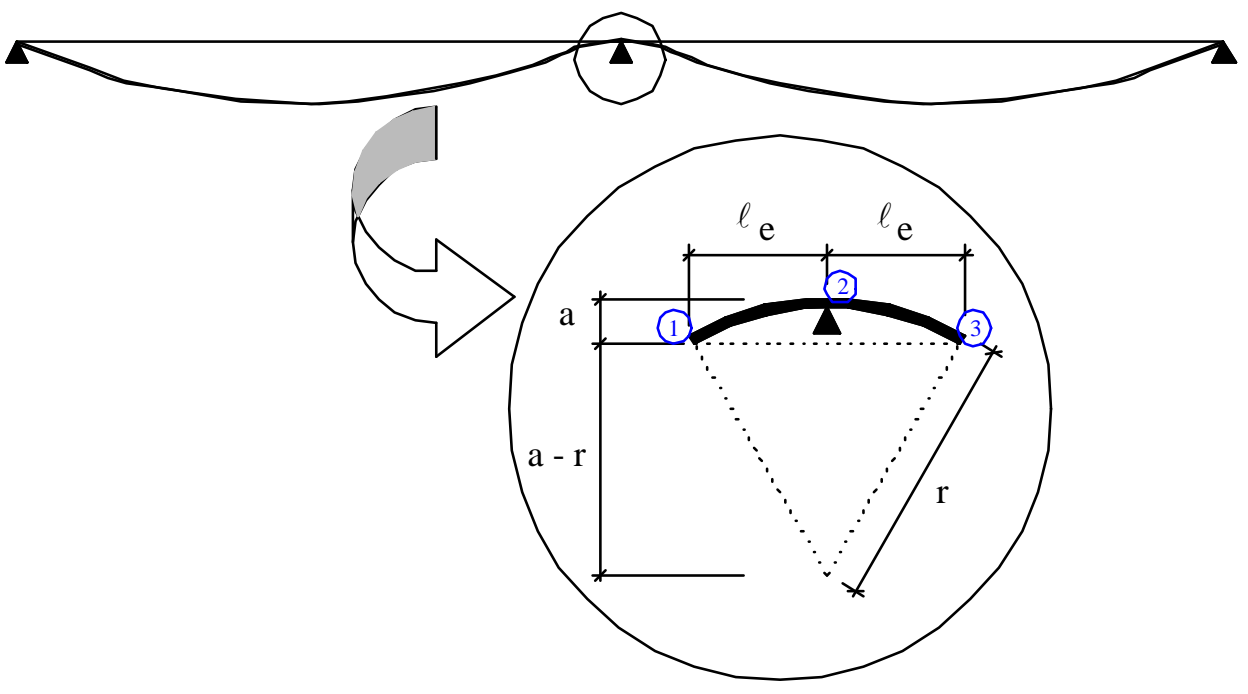

FIGURA 3.8- Determinação da curvatura média a partir dos deslocamentos

b) Capacidade de rotação plástica segundo o modelo de Darmstadt-Leipzig

Como a maior parte dos trabalhos que estudaram experimentalmente a capacidade de rotação das rótulas plásticas utilizou ensaios de elementos unidirecionais de concreto armado simplesmente apoiados com uma força concentrada aplicada no meio do vão, é necessário utilizar o conceito de "viga equivalente" (figura 3.9) para a análise de estruturas estaticamente indeterminadas. A viga equivalente é o segmento da peça entre dois pontos sucessivos de momentos fletores nulos, onde se situa a seção crítica $\left(\mathrm{a}_{\mathrm{q}}\right)$.
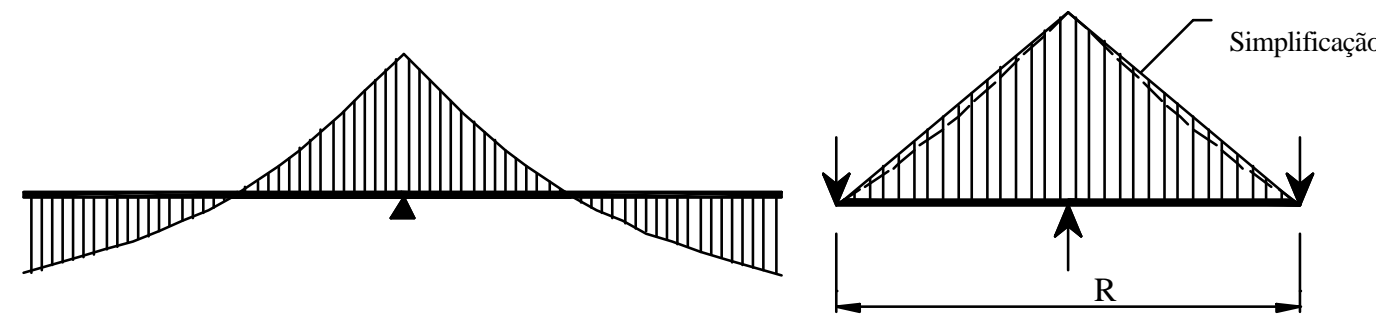

aq

FIGURA 3.9- Viga equivalente na região do apoio central 
O CEB-90 (1991) apresenta as seguintes definições para caracterização das rótulas plásticas:

a) Da integral da curvatura ao longo do comprimento da viga equivalente para carga última, obtém-se a rotação total $\theta$ entre as seções extremas.

b) Da integral da curvatura ao longo do comprimento da viga equivalente para a carga quando ocorre o início do escoamento da armadura, obtémse a rotação elástica $\theta_{\mathrm{el}}$ entre as seções extremas.

c) A rotação plástica $\theta_{\mathrm{pl}}$, ou seja, a capacidade de rotação plástica, decorre da subtração entre a rotação total $\theta$ e a rotação elástica $\theta_{\mathrm{el}}$.

De acordo com item 3.7 do CEB-90 (1991), ao ser assumida uma relação bilinear para o diagrama tensão $x$ deformação da amadura, a capacidade de rotação plástica em estruturas fletidas de concreto armado pode ser obtida a partir da seguinte expressão:

$$
\theta_{\mathrm{pl}}=\int_{0}^{\ell \mathrm{pl}} \frac{\delta}{\mathrm{d}-\mathrm{x}_{\mathrm{LN}}} \cdot\left(1-\frac{\sigma_{\mathrm{sr} 1}}{\mathrm{f}_{\mathrm{yk}}}\right) \cdot\left(\varepsilon_{\mathrm{s} 2}-\varepsilon_{\mathrm{sy}}\right) \mathrm{dx}
$$

onde:

$\ell_{\mathrm{pl}}$ - comprimento da região na qual a armadura tracionada está em escoamento;

$\mathrm{X}_{\mathrm{LN}}$ - posição da linha neutra;

$\delta$ - coeficiente que leva em consideração a forma do diagrama tensão $x$ deformação da armadura após o escoamento;

$\sigma_{\text {sr1 }}$ - é a tensão da armadura na fissura, obtida com as solicitações que levam a seção à fissuração por tensões normais, o que se dá para a tensão na borda do banzo tracionado igual à resistência à tração do concreto;

$\varepsilon_{\mathrm{s} 2}$ - deformação da armadura na fissura;

$\varepsilon_{\mathrm{sy}}-$ deformação de escoamento da armadura

O valor de $\delta$ pode ser adotado em torno de 0,8 para os aços tipo A do CEB-90 (1991). Segundo BUCHAIM \& STUCCHI (2000), o valor deste coeficiente também pode ser considerado, com certa aproximação, igual a 0,8 para os aços nacionais CA-50 e CA-60. 
No caso de uma análise pouco rigorosa, o CEB-90 (1991) permite estimar a capacidade de rotação plástica por meio da figura 3.10. Nesta figura, as ordenadas representam a capacidade de rotação plástica e as abscissas representam os valores de linha neutra no estado limite último, calculados com resistências dos materiais minoradas com coeficientes de segurança e deformações últimas do aço e concreto de, respectivamente, $10 \%$ e $3,5 \%$ o.

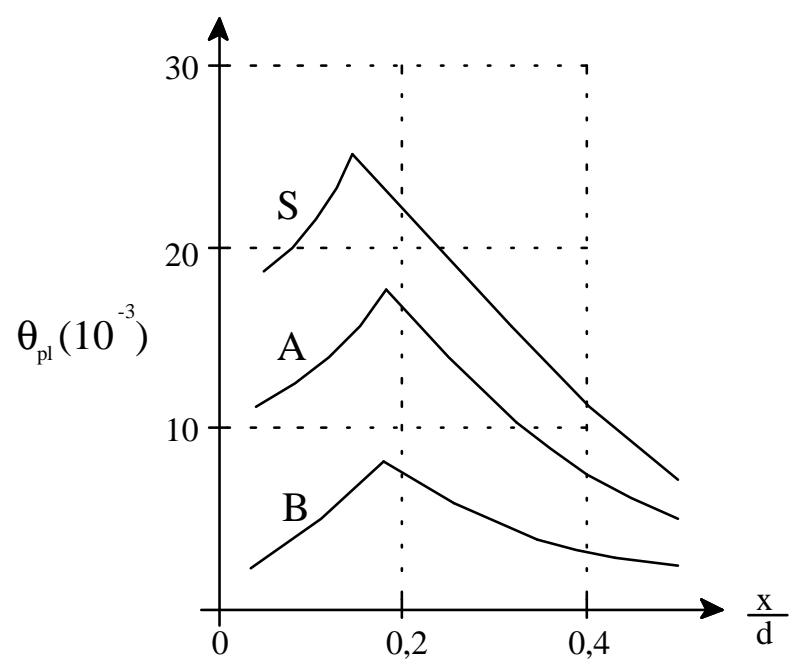

FIGURA 3.10- Capacidade de rotação plástica como função da linha neutra [CEB-90(1991)]

Na figura 3.10, S, A e B são as classes de aços fornecidos pelo CEB-90 (1991). Os valores desta figura são válidos para $\mathrm{a}_{\mathrm{q}} / \mathrm{d}=6$. Em outros casos, $\mathrm{a}$ capacidade de rotação plástica deve ser multiplicada pelo fator $\sqrt{\frac{1}{6} \cdot \mathrm{a}_{\mathrm{q}} / \mathrm{d}}$.

Mais recentemente, o CEB (1998) fornece outros modelos que analisam a capacidade de rotação plástica em estruturas de concreto armado.

No desenvolvimento desta dissertação optou-se em verificar a capacidade de rotação das rótulas plásticas segundo o modelo de Darmstadt-Leipzig, uma vez que sua formulação é apresentada em termos dos parâmetros de momentos e curvaturas.

De acordo com este modelo, a capacidade de rotação plástica está dividida em duas partes que são determinadas separadamente, conforme a seguinte expressão:

$$
\theta_{\mathrm{pl}}=\theta_{\mathrm{pl}, \mathrm{fle}}+\theta_{\mathrm{pl}, \mathrm{cort}}
$$


onde: $\quad \theta_{\mathrm{pl}} \quad$ : capacidade de rotação da rótula plástica;

$\theta_{\mathrm{pl}, \mathrm{fle}}$ : parcela da rotação plástica decorrente do esforço de flexão;

$\theta_{\mathrm{pl}, \mathrm{cort}}$ : parcela da rotação plástica decorrente do esforço cortante.

Sabendo que o esforço predominante em lajes é o de flexão, considerarse-á nas verificações da capacidade de rotação das rótulas plásticas somente a parcela de deformações plásticas decorrente dos esforços de flexão $\left(\theta_{\mathrm{pl}}=\theta_{\mathrm{pl} \text {,fle }}\right)$. Com isto, a capacidade de rotação das rótulas plástica, segundo o modelo de Darmstadt-Leipzig é dada pela seguinte expressão:

$$
\theta_{\mathrm{pl}}=\frac{\mathrm{a}_{\mathrm{q}}}{\mathrm{d}} \cdot\left(\frac{1}{\mathrm{r}_{1 \mathrm{r}}} \cdot \mathrm{d} \cdot\left(\frac{\mathrm{M}_{\mathrm{y}}}{\mathrm{M}_{\mathrm{u}}}-1\right)+\frac{1}{\mathrm{r}_{\mathrm{y}}} \cdot \mathrm{d} \cdot\left(\frac{\mathrm{M}_{\mathrm{r}}}{\mathrm{M}_{\mathrm{y}}}-\frac{\mathrm{M}_{\mathrm{r}}}{\mathrm{M}_{\mathrm{u}}}\right)+\frac{1}{\mathrm{r}_{\mathrm{u}}} \cdot \mathrm{d} \cdot\left(1-\frac{\mathrm{M}_{\mathrm{y}}}{\mathrm{M}_{\mathrm{u}}}\right)\right)
$$

\subsubsection{Critério da formação de um mecanismo de colapso}

Para ilustrar o critério da formação do mecanismo de colapso, seja uma viga engastada numa extremidade e apoiada na outra, com uma carga concentrada $\mathrm{F}$ no centro, como mostra a figura 3.11-a. O diagrama de momentos fletores tem a forma apresentada na figura 3.11-b, com o máximo momento fletor ocorrendo na extremidade engastada.

(a)
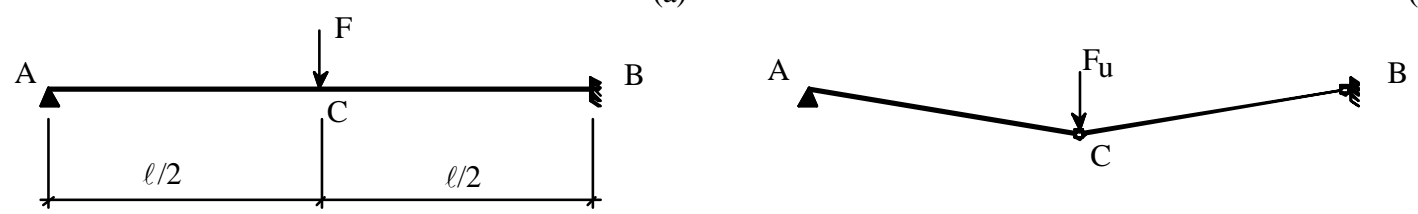

(b)
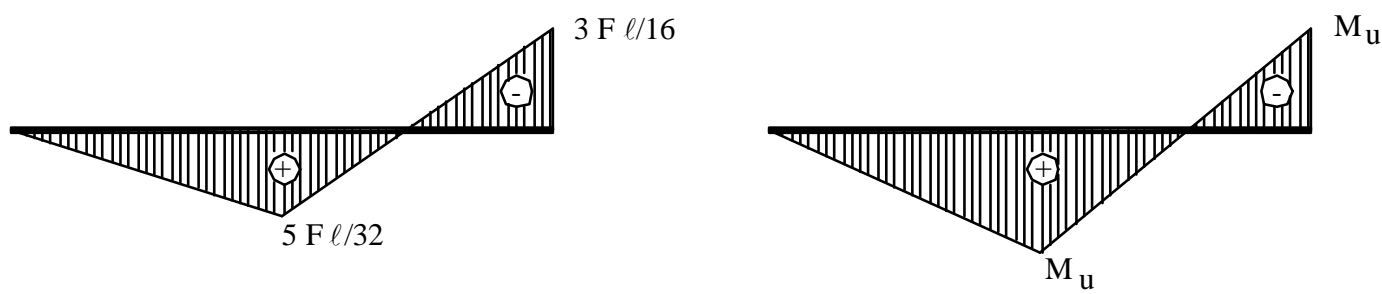

FIGURA 3.11- Critério da formação de um mecanismo de colapso

Com o incremento de carga, a seção B será a primeira a escoar. Após um novo acréscimo de carga em F, começará a ocorrer o escoamento da seção C, onde há um pico no diagrama dos momentos fletores. 
Se a carga continuar crescendo, forma-se uma rótula plástica na extremidade B. Entretanto, esta única articulação não provoca falha do elemento estrutural, pois este se comporta como uma estrutura estaticamente determinada, suportando uma carga $F$ na seção $C$ e um momento fletor $M_{u}$ em B. Com este esquema estático, a estrutura ainda suportará um acréscimo de carga até que o momento fletor em $\mathrm{C}$ também atinja o momento último desta seção. Nesta ocasião, existirão articulações plásticas nas seções A e C e a estrutura formará um mecanismo. Então, existirão deslocamentos ilimitados e não é mais possível nenhum acréscimo de carga, sendo atingida a carga de ruptura.

É importante lembrar que esta situação somente ocorrerá nas modelagens numéricas se a rótula no engaste apresentar capacidade de rotação suficiente para que seja possível também criar uma rótula no meio do vão.

\subsection{O programa propriamente dito}

Conforme mencionado anteriormente, as modelagens numéricas foram realizadas utilizando o programa computacional ANSYS ${ }^{\circledR}$ por apresentar recursos que facilitam a entrada / modificação de dados e visualização dos resultados.

As análises numéricas foram realizadas utilizando o elemento de barra BEAM4-3D Elastic Beam, que faz parte da biblioteca de elementos do ANSYS ${ }^{\circledR}$. Este elemento possui 6 graus de liberdade por nó (translação e rotação nas três direções). Na figura 3.12 estão mostrados os graus de liberdades apresentados por este elemento.

Para a realização das modelagens numéricas, foram construídas "macros" (sub-rotinas) que contêm os procedimentos da técnica do carregamento incremental, as relações momento $x$ curvatura do CEB-90 (1991) e os critérios para a consideração da capacidade de rotação plástica. Estas macros acoplados ao ANSYS ${ }^{\circledR}$ tornaram possível a realização das análises não-lineares de acordo com o modelo teórico apresentado neste capítulo. 


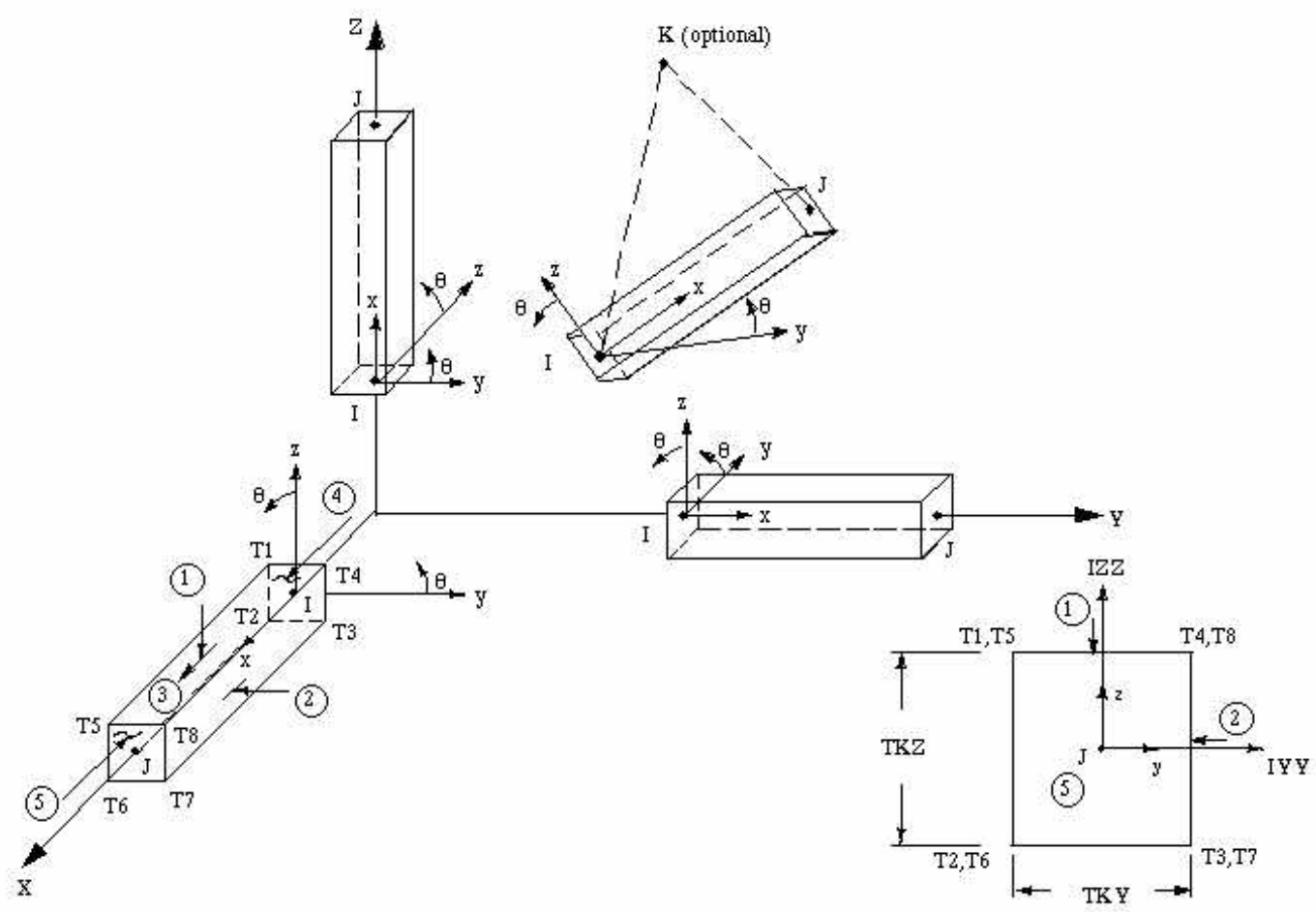

FIGURA 3.12- Elemento BEAM4-3D Elastic Beam [ANSYS ${ }^{\circledR}$ ]

O procedimento utilizado para as modelagens numéricas com a consideração da não-linearidade física do material utilizando o programa computacional ANSYS ${ }^{\circledR}$ pode ser apresentado nas seguintes etapas:

1. Geração da estrutura no $\operatorname{ANSYS}^{\circledR}$ (elementos, vinculações e carregamento);

2. determinação dos esforços segundo análise linear;

3. dimensionamento dos elementos;

4. cálculo das característica mecânicas e geométricas dos elementos $\left(\mathrm{I}_{1}, \mathrm{I}_{2}\right.$, $\mathrm{M}_{\mathrm{r}}, \mathrm{M}_{\mathrm{y}}, 1 / \mathrm{r}_{\mathrm{y}}, \mathrm{M}_{\mathrm{u}}$ e 1/ $\left.\mathrm{r}_{\mathrm{u}}\right)$

5. introdução das características mecânicas e geométricas como dados de entrada nas “macros" do ANSYS ${ }^{\circledR}$;

6. realização da análise não-linear incremental;

7. saída e análise dos resultados.

Na figura 3.13 está mostrado o esquema para se proceder a análise nãolinear. 


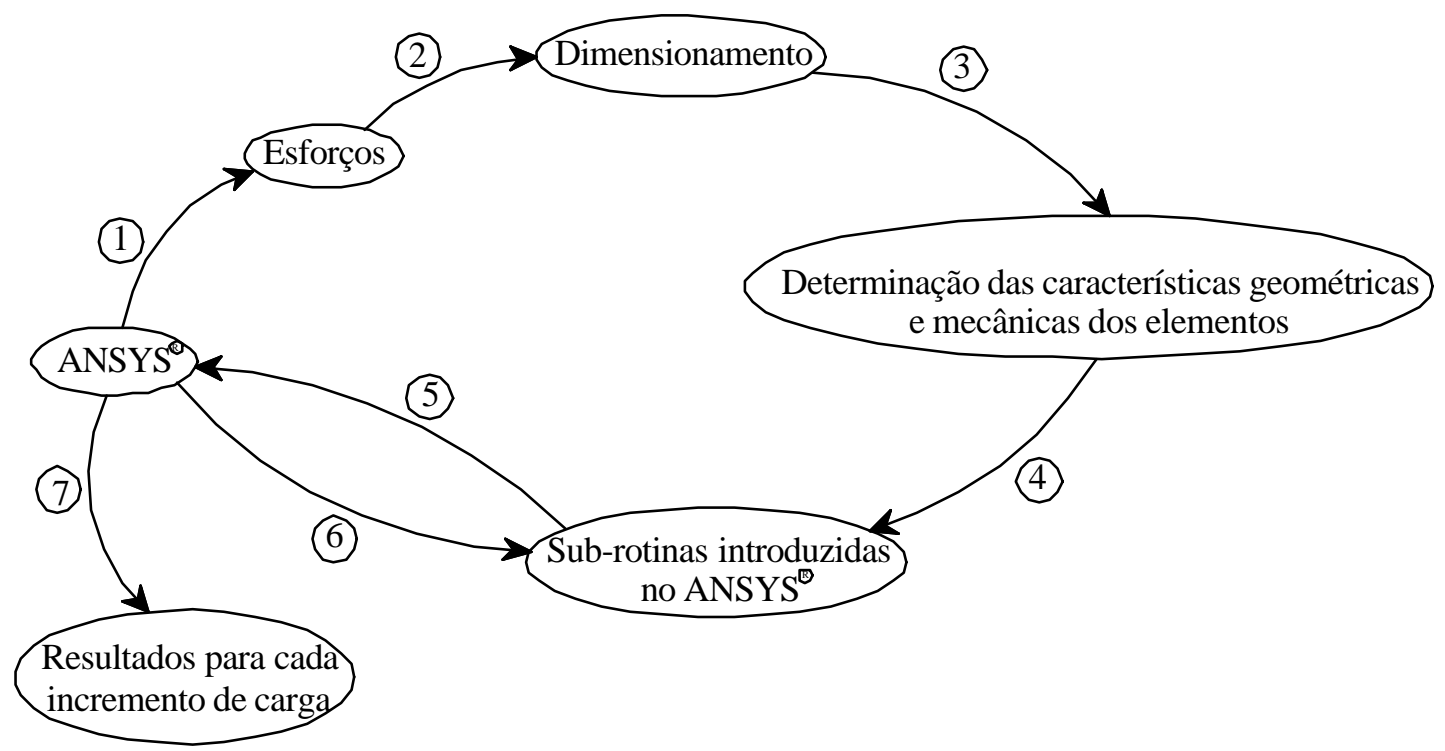

FIGURA 3.13- Fluxograma para análise não-linear utilizando o programa ANSYS ${ }^{\circledR}$

Dentre os elementos existentes na biblioteca do ANSYS ${ }^{\circledR}$, o elemento SOLID65 3-D Reinforced Concrete Solid possibilita a análise não-linear em estruturas de concreto armado. Este elemento simula as propriedades mecânicas do concreto armado, incluindo a perda de rigidez devido à fissuração. Ao se utilizar este elemento, a estrutura não é mais discretizada em elementos de barras uniaxiais e sim modelada como uma estrutura tridimensional com as dimensões iguais à estrutura real.

DROPPA JÚNIOR (1999) estudou as características gerais do elemento SOLID65 3-D Reinforced Concrete Solid e os meios de se realizar a análise nãolinear em lajes nervuradas mediante os critérios de convergência e de equilíbrio. Entretanto, as modelagens numéricas não obtiveram o sucesso esperado por causa da grande complexidade da análise não-linear em sólidos e dos critérios próprios de convergência do programa. 


\subsection{Considerações iniciais}

Para avaliar a validade do comportamento teórico desenvolvido neste trabalho para lajes nervuradas, foi previsto um programa experimental que consistiu no ensaio à flexão em faixas de lajes contínuas formadas por elementos prémoldados tipo vigota com armação treliçada, elementos de enchimento em EPS e concreto moldado no local.

Os procedimentos envolvidos na experimentação descritos neste capítulo podem ser resumidos da seguinte forma:

- Características gerais dos modelos: justificativas das dimensões adotadas, carregamentos e dimensionamento.

- Descrição dos ensaios: Projeto e execução das fôrmas de madeira; montagem das armaduras; instrumentação e posicionamento na fôrma; moldagem das lajes; transporte da laje para posição definitiva de ensaio; execução dos ensaios.

- $\quad$ Caracterização mecânica dos materiais.

- Elaboração dos diagramas experimentais. 


\subsection{Definições gerais dos modelos ensaiados}

\subsubsection{Definição das dimensões}

Foram realizados ensaios experimentais em três faixas de lajes nervuradas contínuas constituídas por vigotas pré-moldadas com armação treliçada, elementos de enchimento em EPS e concreto moldado no local.

As medidas idealizadas para os modelos foram tomadas a partir da análise do trabalho de CALAVERA et al. (1988) com as seguintes particularidades:

- As faixas de lajes ensaiadas possuem 1,0 metro de largura por 8,20 metros de comprimento. Na figura 4.1 é mostrada a fôrma dos elementos estruturais e nas figuras 4.2 e 4.3 são mostrados, respectivamente, os cortes longitudinal e transversal.

- A seção transversal da laje é formada por duas nervuras de $10 \mathrm{~cm}$ de largura, com enchimento em EPS completo entre elas e meio bloco em cada extremidade totalizando $100 \mathrm{~cm}$ de largura. A altura total utilizada no dimensionamento foi de $12 \mathrm{~cm}$, onde $4 \mathrm{~cm}$ foi de capeamento.

A dimensão de $1 \mathrm{~m}$ de largura para o elemento estrutural permite obter um intereixo (distância entre os eixos das nervuras) de $50 \mathrm{~cm}$, valor comumente utilizado no sistema construtivo em que são usadas as lajes pré-moldadas.

As vigotas pré-moldadas utilizadas na construção de todos os modelos são constituídas pela armação treliçada do tipo TR08634 mostrada na figura 4.4, que apresenta as seguintes características geométricas:

- Altura da treliça:

- Diâmetro do fio do banzo superior:

- Diâmetro dos fios das diagonais:

- Diâmetro dos fios do banzo inferior:

- Peso por metro linear de treliça: 80mm;

6,0mm;

3,4mm;

4,2mm;

$0,625 \mathrm{~kg}$. 

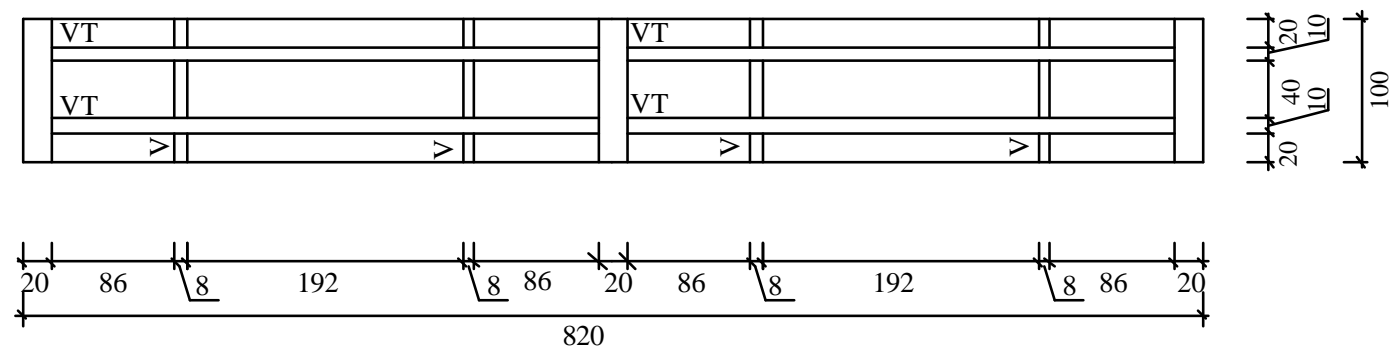
VT - Vigota pré-moldada com armação treliçada V - Vigota transversal

FIGURA 4.1 - Planta de fôrma do elemento estrutural - dimensões em cm

Armadura construtiva
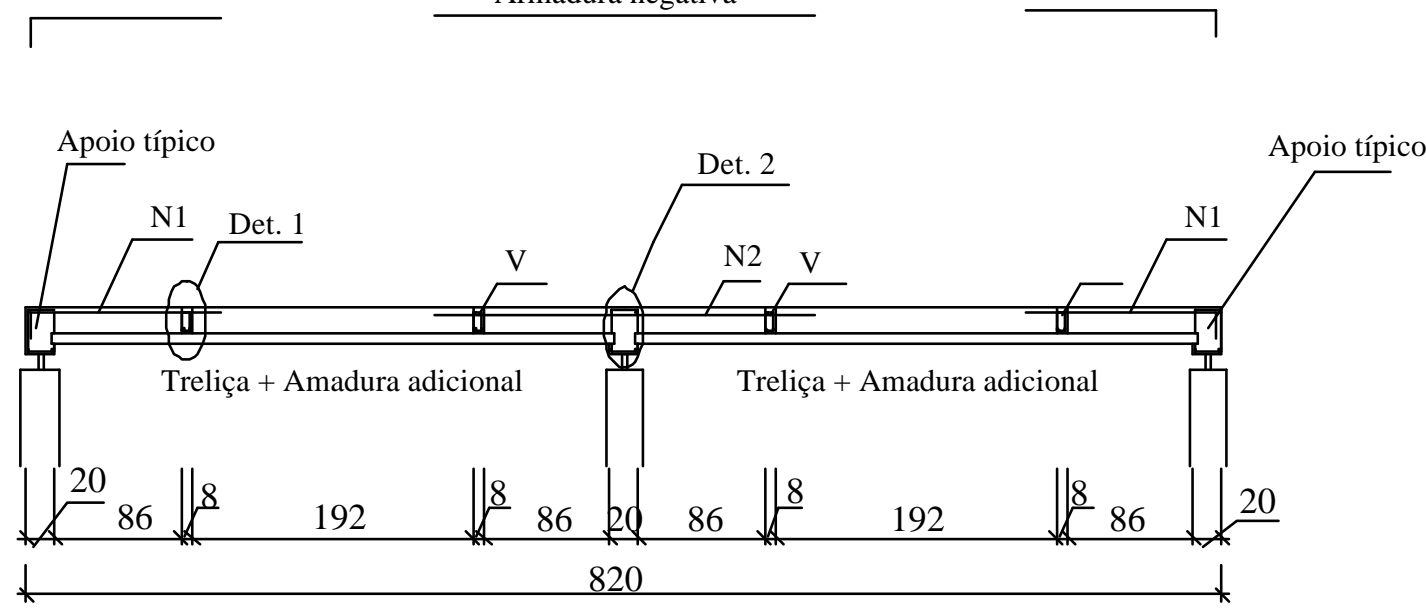

FIGURA 4.2 - Corte longitudinal do elemento estrutural - dimensões em cm
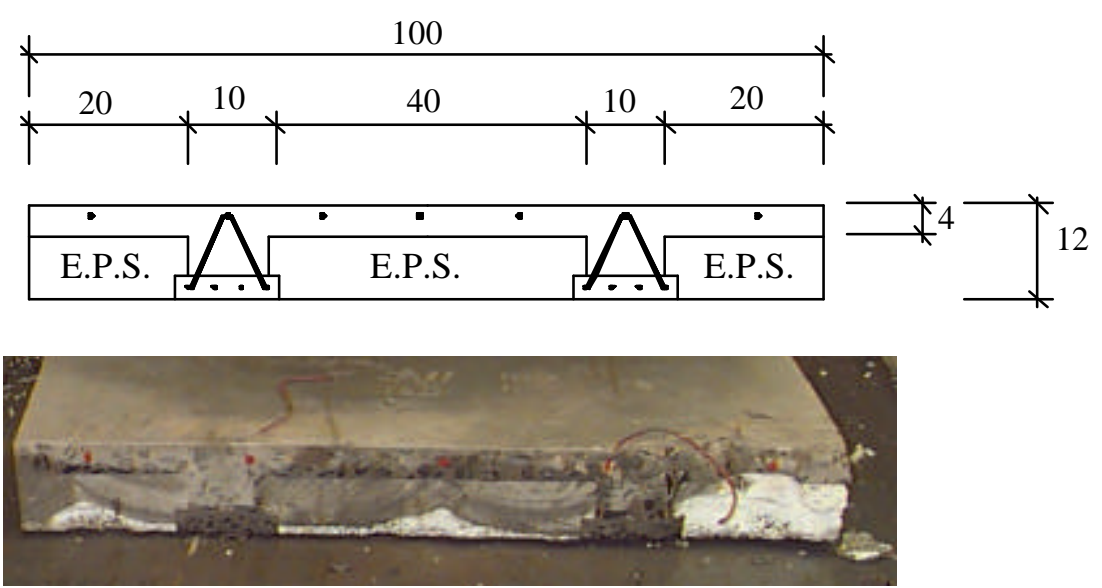

FIGURA 4.3 - Seção transversal dos elementos estruturais- dimensões em cm 


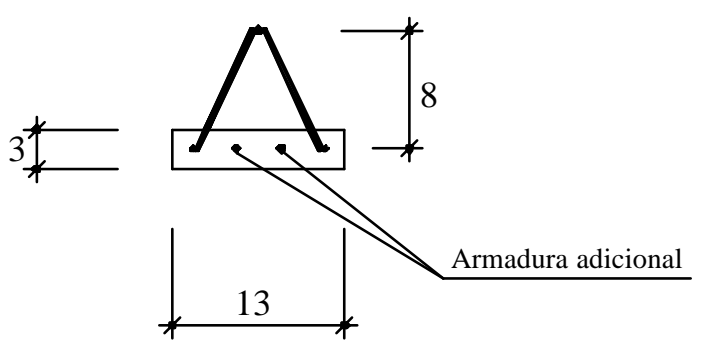

FIGURA 4.4 - Esquema geral da vigota - dimensões em cm

Adotou-se para os modelos uma altura total de $12 \mathrm{~cm}$ por ser um valor amplamente empregado para as vigotas pré-moldadas na prática profissional. Utilizando-se também as recomendações de FRANCA \& FUSCO (2000) e PEREIRA (2000), seria encontrado o mesmo valor de altura para o vão de $4 \mathrm{~m}$ a ser vencido pelos modelos.

A espessura do capeamento foi determinada a partir das recomendações da NBR-6118 (1978), onde não é permitido valor inferior a 1/15 da distância livre entre nervuras ou $4 \mathrm{~cm}$. O projeto de norma de Laje pré-fabricada (projeto 02:107.01001 - versão 29/05/00) também especifica a espessura mínima da capa resistente de concreto em $4 \mathrm{~cm}$ para uma laje com altura total de $12 \mathrm{~cm}$, conforme apresentada na tabela 2.1 do capítulo 2 .

Cada vigota treliçada possui uma base de concreto com $(3 x 13) \mathrm{cm}^{2}$ de seção transversal que irá envolver a armadura do banzo inferior da treliça e a armadura adicional obtida no dimensionamento. A figura 4.4 mostra um esquema geral da vigota treliçada utilizada nos ensaios.

Nos locais de aplicação das forças pelos atuadores hidráulicos, foram colocadas nervuras transversais de modo a distribuir as forças concentradas. $\mathrm{O}$ detalhe destas nervuras pode ser visto na figura 4.5. Embora não seja usual a colocação de estribos nas nervuras transversais, optou-se por colocá-los nos modelos ensaiados de modo a evitar possíveis problemas no local de aplicação das forças concentradas.

Nos apoios das faixas de lajes ocorre um aumento de $4 \mathrm{~cm}$ na altura conforme está mostrado na figura 4.6. Este aumento na altura dos modelos nas regiões dos apoios é justificado para promover um maior enrijecimento e assim evitar rupturas localizadas durante a realização dos ensaios. 
Na capa de concreto foi colocada armadura de distribuição posicionadas transversalmente `as nervuras dos modelos. Esta armadura foi calculada baseando-se nas recomendações expressas pela norma espanhola EF-96 (1997), o que conduziu a utilizar barras de diâmetro de 4,2 espaçadas a cada $25 \mathrm{~cm}$.
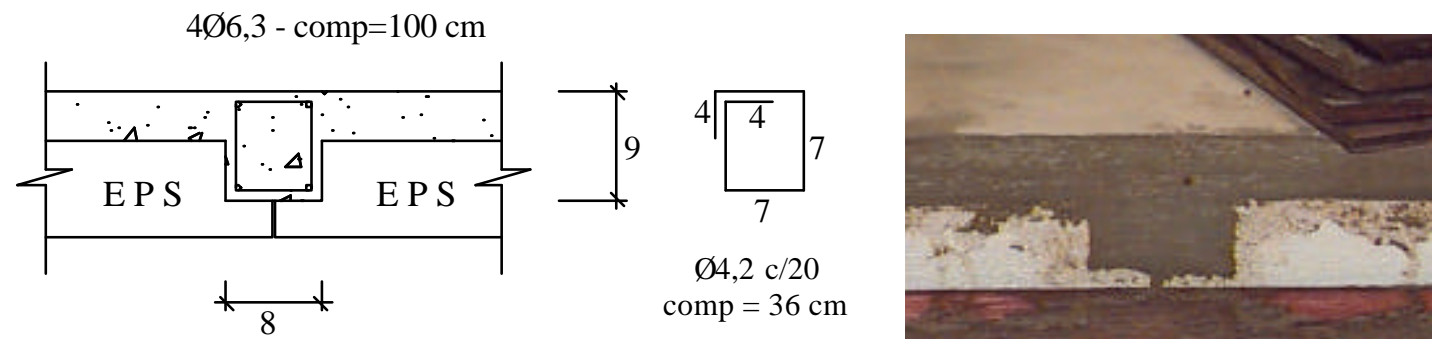

FIGURA 4.5 - Nervura transversal
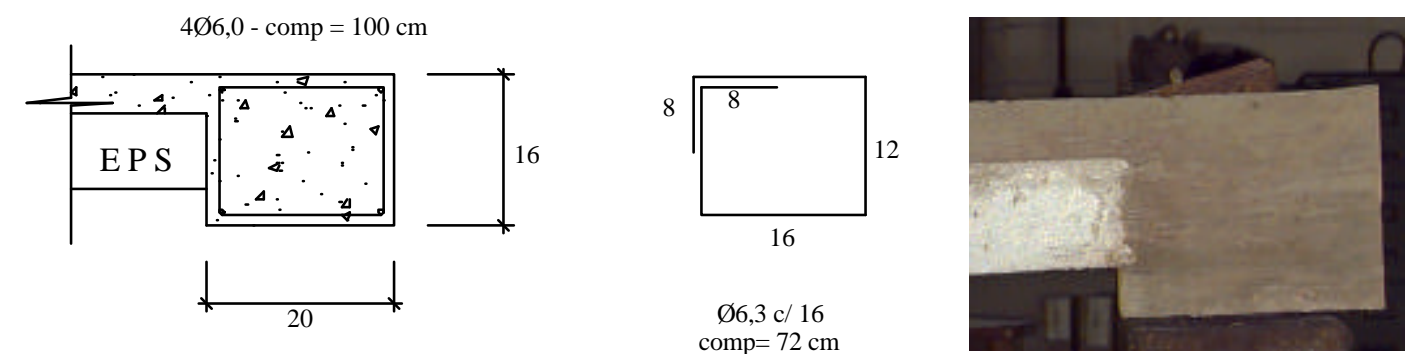

FIGURA 4.6 - Viga de apoio

$\mathrm{Na}$ construção de cada modelo foi utilizado em torno de $0,57 \mathrm{~m}^{3}$ de concreto, o que conduziu um peso total de $1,43 \mathrm{tf}(14,3 \mathrm{kN})$.

\subsubsection{Definição da armadura de continuidade estrutural}

As ações consideradas no dimensionamento foram uniformemente distribuída ao longo do elemento, obtidas a partir do peso próprio do concreto armado de massa específica de $25 \mathrm{kN} / \mathrm{m}^{3}$, elemento de enchimento em EPS com massa específica de $0,12 \mathrm{kN} / \mathrm{m}^{3}$, idealizando uma carga permanente de revestimento de $0,50 \mathrm{kN} / \mathrm{m}^{2}$ e carga de utilização de $2,0 \mathrm{kN} / \mathrm{m}^{2}$. O coeficiente de majoração das forças utilizado no dimensionamento foi $\gamma_{\mathrm{f}}$ igual a 1,4. Na figura 4.7 está mostrado o esquema estático utilizado para o cálculo de esforços para se proceder ao dimensionamento. 


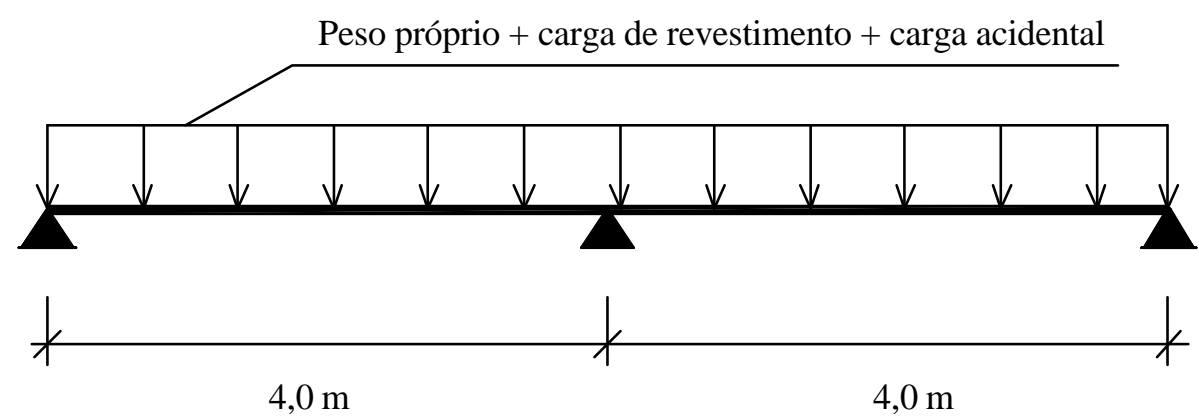

FIGURA 4.7 - Ações utilizadas no dimensionamento

O dimensionamento das faixas de lajes foi realizado considerando a resistência característica à compressão do concreto $\left(\mathrm{f}_{\mathrm{ck}}\right)$ igual a $20 \mathrm{MPa}\left(2,0 \mathrm{kN} / \mathrm{cm}^{2}\right)$ e armaduras em aço CA 60. Os coeficientes utilizados na minoração das resistências dos materiais aço e concreto foram, respectivamente, 1,15 e 1,40.

De modo a avaliar a resposta que a estrutura apresenta ao ser imposta uma redistribuição de momentos fletores na fase de dimensionamento, cada faixa de laje foi dimensionada considerado-se análise elástico-linear com rigidez constante supondo $15 \%$ de redistribuição dos momentos fletores negativos (Modelo dimensionado com $\underline{15} \%$ de redistribuição - M15), $40 \%$ de redistribuição dos momentos fletores negativos (Modelo dimensionado com $\underline{40} \%$ de redistribuição M40) e um modelo dimensionado com tramos isolados com armadura construtiva para controle de fissuração no apoio intermediário (Modelo com armadura construtiva - Mac).

A adoção destes valores está fundamentada nos seguintes critérios:

a) Considerando-se $15 \%$ de redistribuição dos momentos fletores negativos para o modelo M15, está sendo utilizado o valor limite de redistribuição de momentos fletores segundo a norma espanhola EF-96 (1997).

b) Para o modelo M40 é considerada uma redistribuição de $40 \%$ dos momentos fletores negativos, valor de redistribuição superior ao valor limite recomendado pela norma EF-96 (1997). Por meio deste modelo será possível avaliar a capacidade das rotações plásticas.

c) No modelo dimensionado com tramos isolados com armadura construtiva no apoio intermediário (modelo Mac), o dimensionamento é realizado considerando faixas de lajes simplesmente apoiadas, onde é colocada 
apenas armadura construtiva para limitar a abertura de fissuras. Esta armadura construtiva proporciona uma pequena continuidade entre os vãos, equivalente a armadura que se obteria com o momento fletor de continuidade negativo elástico linear com rigidez constante reduzido em $60 \%$.

Além destes três modelos, inicialmente estava previsto o ensaio de mais um modelo $(M O)$ dimensionado sem redistribuição de momentos fletores negativos, ou seja, a partir de uma análise elástico-linear com rigidez constante. Este modelo não chegou a ser construído pelo fato que, no período previsto para a construção dos modelos e realização dos ensaios, o Laboratório de Estruturas da EESC estava com o cronograma comprometido decorrente do atraso ocorrido em outros ensaios.

As armaduras negativas, tipo de vigota com armação treliçada e armadura adicional disposta na base de concreto pré-moldado utilizadas na construção de cada modelo estão dispostas na tabela 4.1. Nesta mesma tabela ainda é apresentado o consumo da armadura de flexão com e sem a armação treliçada.

$\mathrm{Na}$ escolha dos diâmetros das barras de aço, procurou-se utilizar um conjunto de barras que mais se aproximasse da área de aço calculada no dimensionamento.

TABELA 4.1 - Armadura de flexão dos modelos M15, M40 e Mac

\begin{tabular}{|c|c|c|c|c|c|}
\hline Modelo & Armadura & Armação & \multirow{2}{*}{$\begin{array}{c}\text { Armadura } \\
\text { ndicional }\end{array}$} & \multicolumn{2}{|c|}{$\begin{array}{c}\text { Consumo de armadura de } \\
\text { flexão (kg) }\end{array}$} \\
\cline { 5 - 6 } & & & & s/ treliça & c/ treliça \\
\hline M15 & $8 \phi 6,0$ & TR08634 & $2 \phi 4,2+1 \phi 3,4$ & 8,88 & 18,88 \\
\hline M40 & $5 \phi 6,0$ & TR08634 & $2 \phi 5,0+1 \phi 4,2$ & 9,34 & 19,34 \\
\hline Mac & $6 \phi 4,2$ & TR08634 & $3 \phi 6,0$ & 12,22 & 22,22 \\
\hline
\end{tabular}

$\mathrm{Na}$ construção dos modelos, ainda foram utilizadas as seguintes armaduras que são comuns a cada um dos modelos:

- Armadura de distribuição: 33 \$ 4,2 - comp = $100 \mathrm{~cm}$;

- Armadura longitudinal das vigas de travamento: $16 \phi 6,3$ - comp $=100 \mathrm{~cm}$;

- Armadura transversal das vigas de travamento: $24 \phi 4,2$ - comp = $36 \mathrm{~cm}$; 
- Armadura longitudinal dos apoios: 12 \% 6,3 - comp = $100 \mathrm{~cm}$;

- Armadura transversal dos apoios: 18 ф 6,3 - comp = $72 \mathrm{~cm}$;

- Armadura construtiva dos apoios externos: $12 \phi 4,2-\operatorname{comp}=125 \mathrm{~cm}$.

\subsection{Descrição dos ensaios}

Para a realização do programa experimental, as seguintes etapas foram seguidas:

a- Instrumentação das barras de aço;

b- $\quad$ Construção das fôrmas de madeira;

c- Posicionamento das vigotas pré-moldadas, elementos de enchimento e barras de aço nas fôrmas;

d- Moldagem, envolvendo lançamento, adensamento e cura do concreto

e- Desmoldagem, içamento, transporte e posicionamento no pórtico de ensaio;

f- Instrumentação e execução do ensaio até se caracterizar a ruína;

g- Ensaio à compressão axial de corpos-de-prova cilíndricos de $15 \mathrm{~cm} x$ $30 \mathrm{~cm}$ para obter a resistência à compressão e o módulo de elasticidade do concreto no dia de ensaio;

h- Ensaio à tração diametral de corpos-de-prova cilíndricos de $15 \mathrm{~cm} x 30 \mathrm{~cm}$ para obter a resistência à tração no dia de ensaio;

i- $\quad$ A partir do sistema de aquisição de dados, elaboração das planilhas e, em seguida, os diagramas necessários para a realização das análises.

\subsubsection{Execução das fôrmas}

As fôrmas foram projetadas e em seguida executadas em madeira compensada de $20 \mathrm{~mm}$ de espessura, dispostas junto às laterais dos modelos e nos apoios. Para dar a altura desejada nos apoios, as vigotas pré-moldadas e os elementos de enchimento foram dispostos sobre caibros espaçados a cada metro, o que simulou 
os pontaletes utilizados pela construção civil. Nas figuras 4.8 a 4.11 podem ser vistos os detalhes das fôrmas.

Inicialmente estava prevista a construção de uma única fôrma que seria utilizada na construção de todos os modelos. Entretanto, para ajustar os ensaios das lajes ao cronograma do Laboratório de Estruturas da EESC-USP, optou-se em construir três fôrmas de modo que os modelos M15, M40 e Mac fossem concretados no mesmo dia e ensaiados após duas semanas. Assim, duas fôrmas seriam construídas lado-a-lado economizando a madeira compensada do lado em comum entre elas. A terceira fôrma seria construída numa posição independente.

À medida que as fôrmas que possuem um lado em comum eram construídas, observou-se que a sua execução ficaria facilitada caso fossem utilizadas vigotas de madeiras $(6 \mathrm{~cm} \times 12 \mathrm{~cm})$ junto às laterais no lugar do compensado de madeira, eliminando, assim, a necessidade da criação de dispositivos que evitassem que as fôrmas se abrissem com o empuxo provocado pelo concreto ainda fresco. Esta solução foi adotada na construção do modelo Mac. Após a concretagem desse modelo, observou-se que este apresentava a capa de concreto $1 \mathrm{~cm}$ mais espessa que os modelos M15 e M40. Ao se analisar este fato, ficou constatado que a vigota de madeira apresentava dimensões ligeiramente superiores àquela na qual foi especificada na compra $(12 \mathrm{~cm})$ e, aliado ao inchamento que esta apresentou com os procedimentos envolvidos na concretagem, totalizou $13 \mathrm{~cm}$ para a altura total da vigota de madeira.

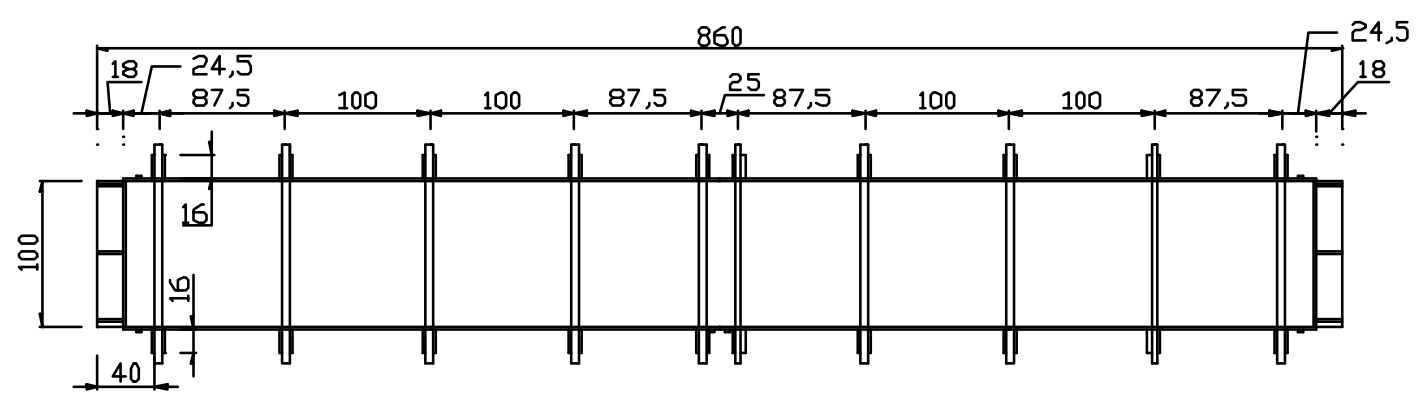

FIGURA 4.8 - Vista superior das fôrmas

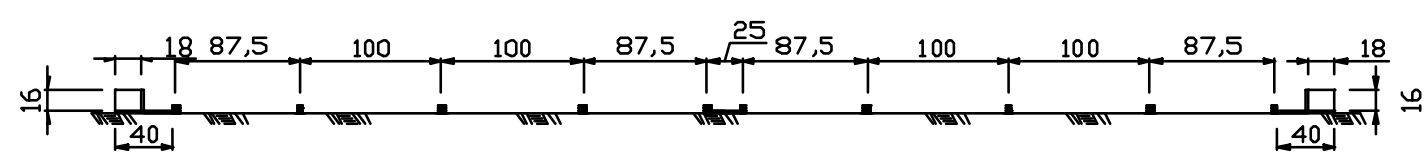

FIGURA 4.9 - Corte longitudinal das fôrmas 


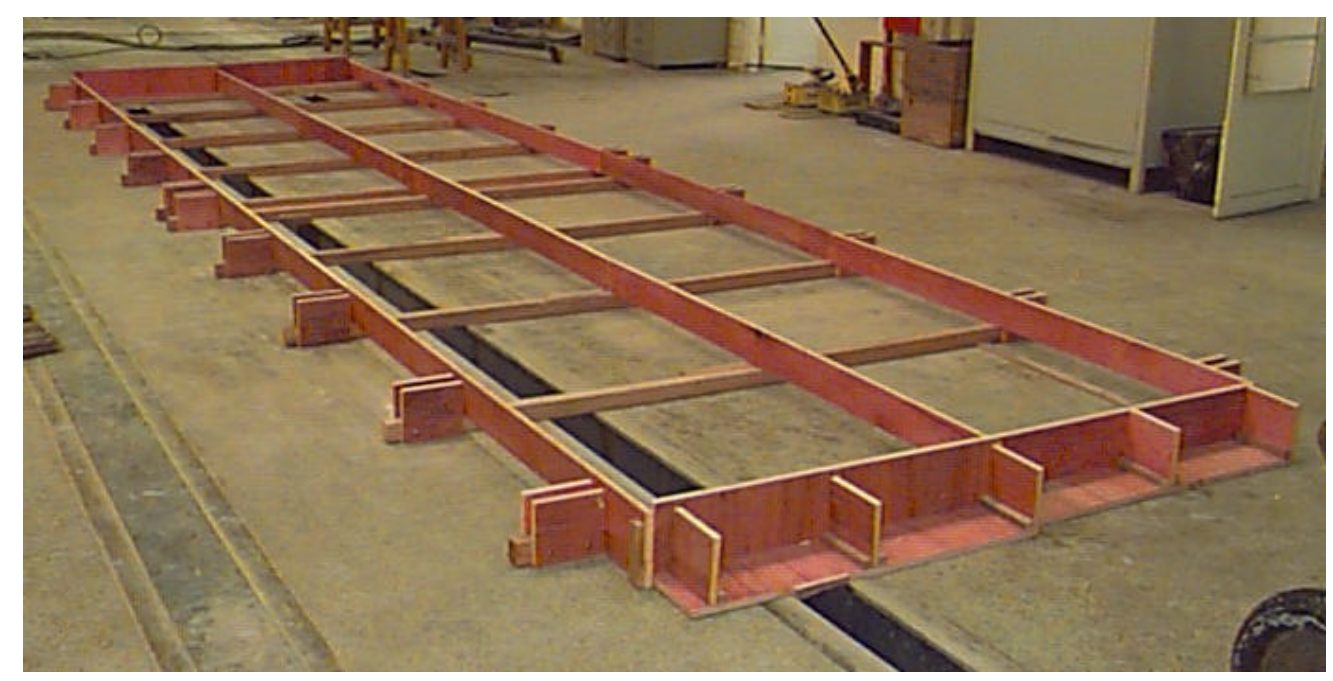

FIGURA 4.10 - Vista geral das fôrmas

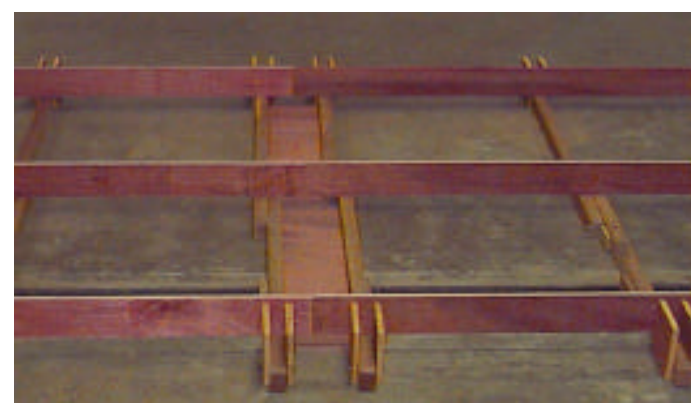

Apoio interno

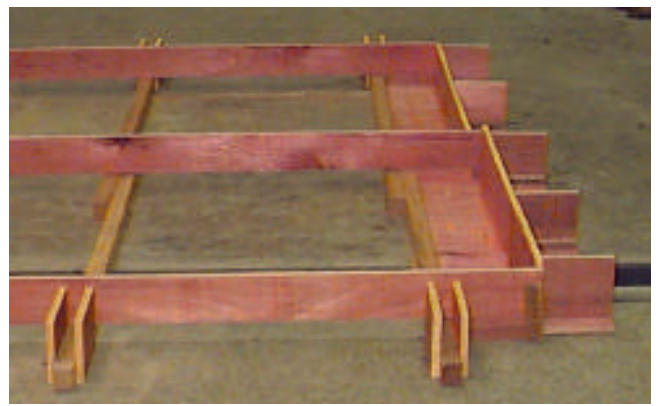

Apoio externo

FIGURA 4.11 - Detalhes da fôrma dos modelos

\subsubsection{Montagem, moldagem, adensamento e cura}

Com as fôrmas prontas, a montagem da laje consistiu nas seguintes etapas:

- posicionamento das vigotas pré-moldadas;

- colocação dos elementos de enchimento;

- colocação das armaduras dos apoios e armaduras das nervuras transversais;

- $\quad$ colocação da armadura de distribuição;

- posicionamento das armaduras negativas no apoio central e armaduras construtivas nos apoios extremos. 
Nas figuras 4.12 a 4.15 é mostrado todo o processo para a montagem das faixas de lajes.

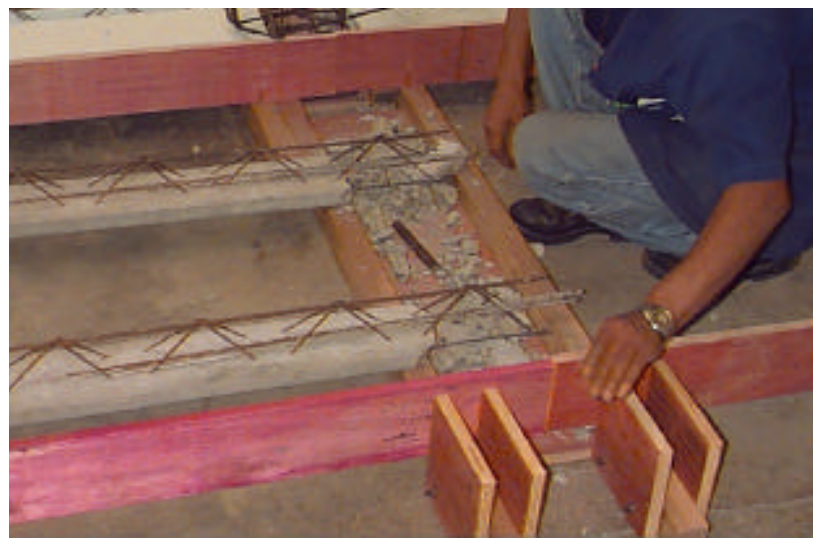

FIGURA 4.12 - Posicionamento das vigotas pré-moldadas

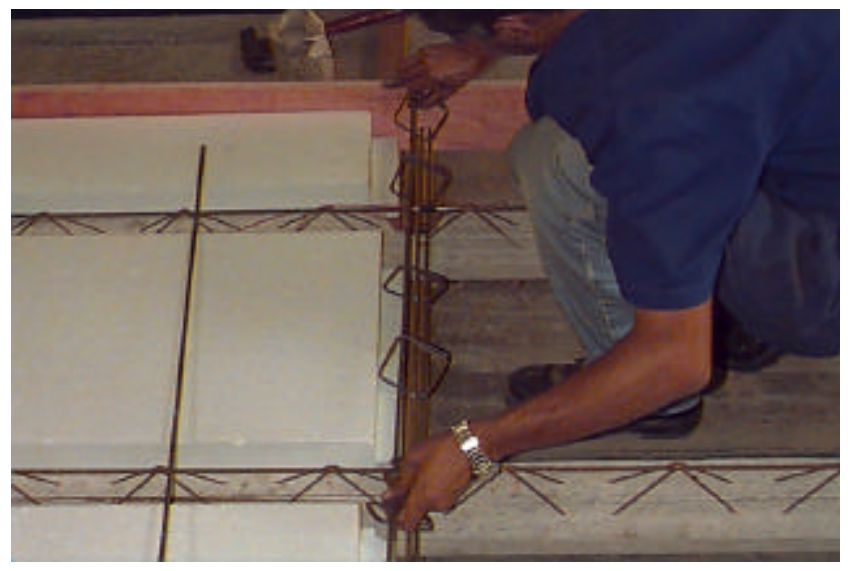

FIGURA 4.13 - Colocação dos elementos de enchimento e fixação das nervuras transversais

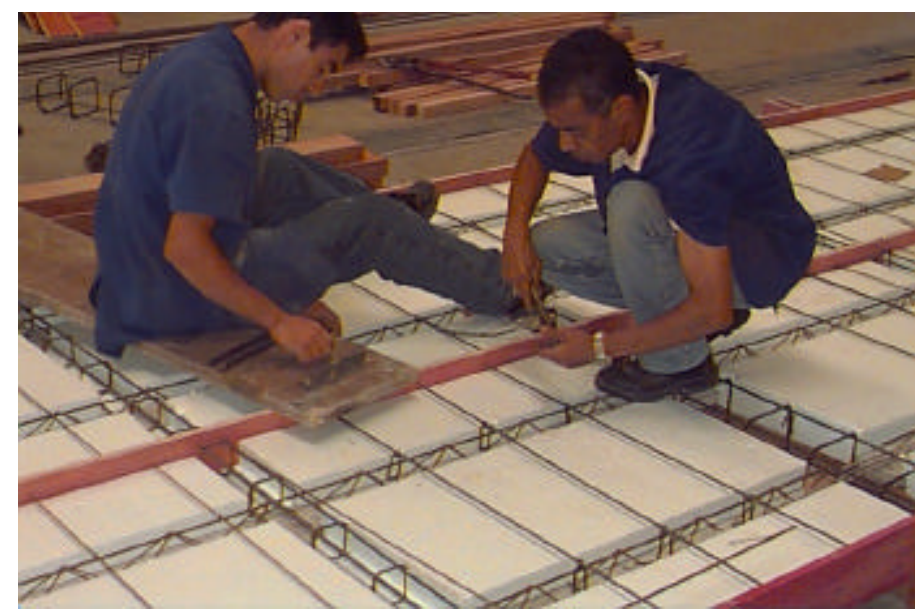

FIGURA 4.14 - Fixação da armadura de distribuição 


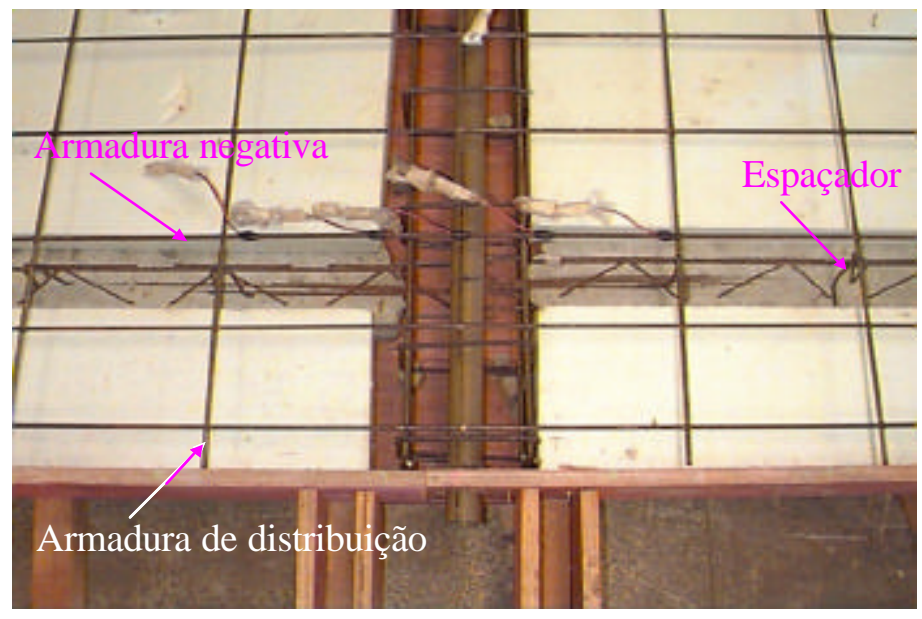

FIGURA 4.15 - Fixação da armadura negativa

Para assegurar que a armadura negativa ficasse na posição correta no capeamento de concreto, a armadura de distribuição que fica nas proximidades do apoio interno foi suspensa utilizando-se espaçadores feitos de sobras de barras de aço. Fixando a armadura negativa à armadura de distribuição suspensa, ficou garantida a altura útil da armadura negativa adotada no projeto.

Um dia antes da concretagem os modelos foram molhadas para retirada do material pulverulento. Além disso, com as fôrmas úmidas, a madeira compensada inchou eliminando, assim, as eventuais aberturas que as fôrmas possuíam e ainda evitaria a absorção da água utilizada no amassamento do concreto.

Como o misturador de concreto do Laboratório de Estruturas da EESC possui capacidade de $240 \ell$, seriam necessárias várias operações para a construção de cada modelo. Portanto, optou-se em utilizar concreto misturado em usina. O adensamento do concreto foi realizado com vibrador de imersão (figura 4.16).

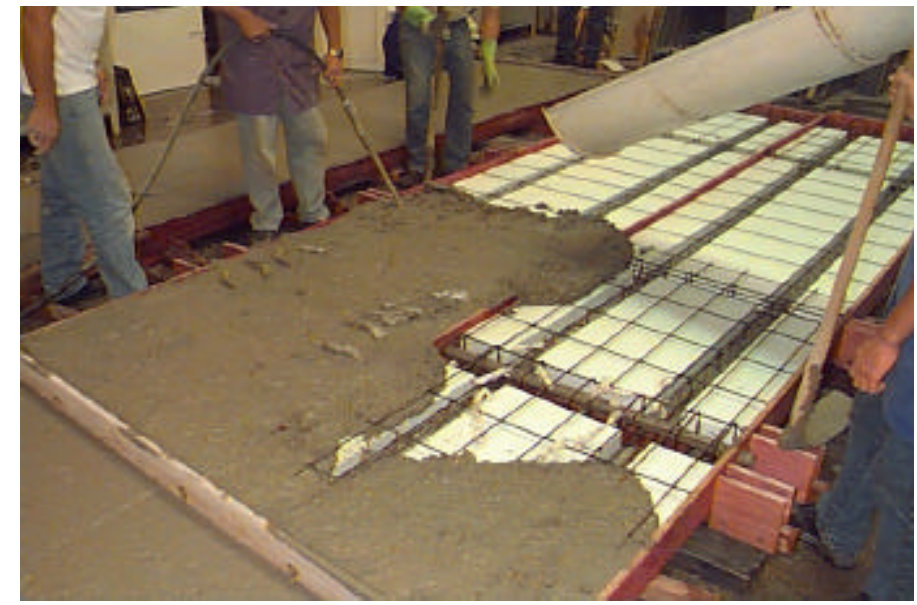

FIGURA 4.16 - Lançamento e adensamento do concreto 
Durante a concretagem, observou-se que os blocos de EPS das laterais dos modelos começaram a se deformar excessivamente em função do peso do concreto fresco e por não estarem apoiados nas quatro bordas (os blocos de extremidades estavam apoiados em três bordas). A solução encontrada naquele momento foi a improvisação de novos pontos de apoio para os blocos de EPS. Para tanto, utilizaram-se perfis metálicos existentes no depósito do Laboratório de Estruturas posicionados entre os caibros das fôrmas. Na figura 4.17 pode ser vista a colocação destes perfis metálicos.

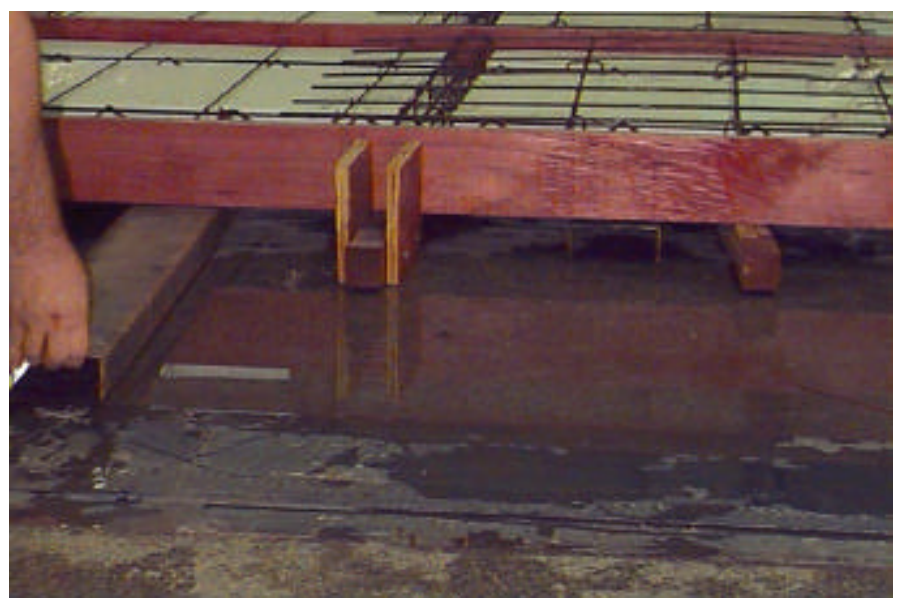

FIGURA 4.17 - Improvisação do escoramento dos blocos de EPS no dia da concretagem

Embora tenha procurado minimizar o efeito da deformação do EPS, a capa de concreto dos modelos apresentou em média $5 \mathrm{~mm}$ mais espessa do que a espessura de capa inicialmente prevista.

Após a concretagem, os modelos permaneceram na fôrma por 7 dias e a cura se deu com o uso de uma lona plástica colocada sobre os modelos. Ainda consistiu como procedimento da cura molhar periodicamente os modelos.

\subsubsection{Estrutura de reação}

A estrutura de reação necessária na aplicação das forças era composta basicamente por dois pórticos metálicos planos e a laje de reação do Laboratório de Estruturas do Departamento de Estruturas da EESC-USP. Na figura 4.18 é mostrada uma visão geral da estrutura de reação. 


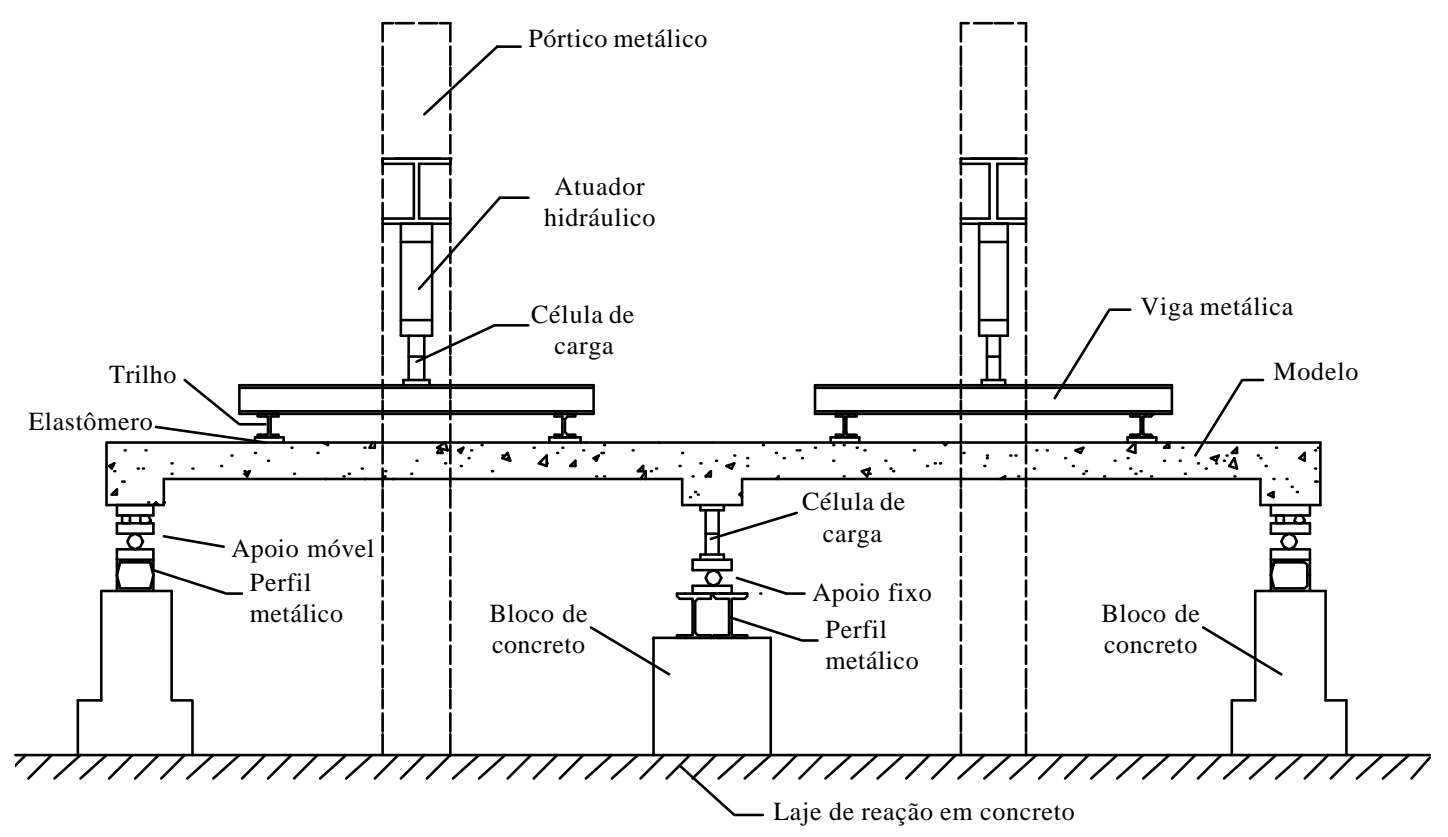

Vista Lateral

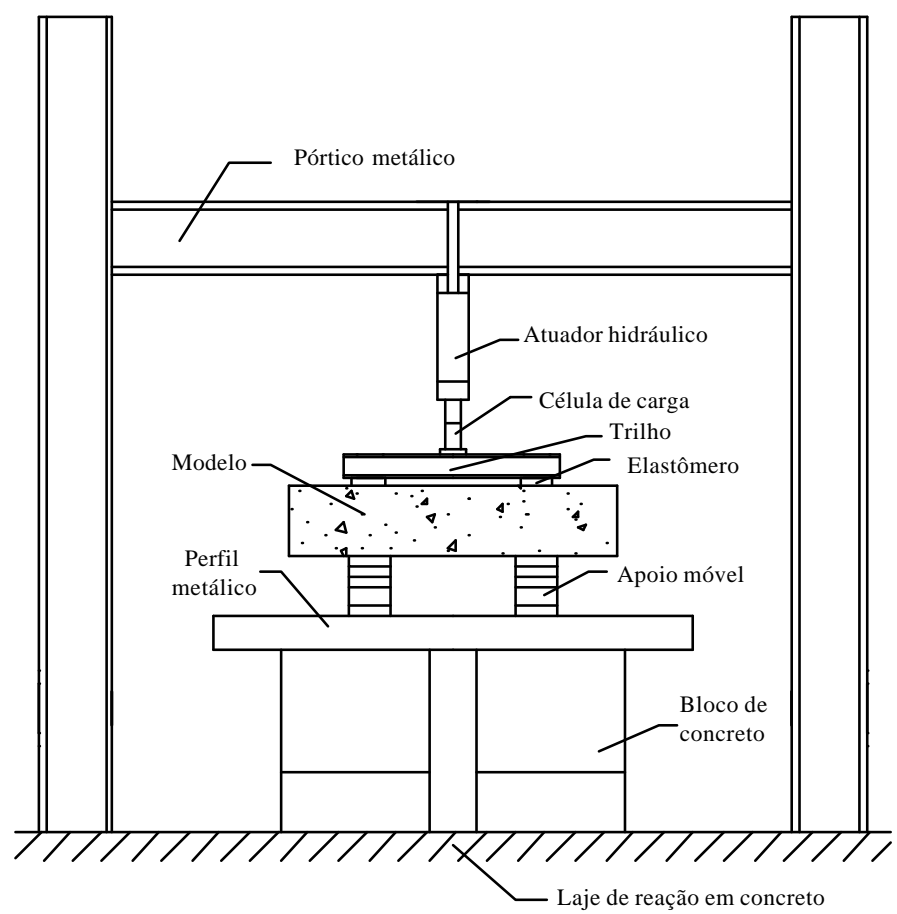

Vista frontal

FIGURA 4.18 - Estrutura de reação 


\subsubsection{Transporte dos modelos para posição de ensaio}

Como as faixas de lajes não foram construídas na sua posição definitiva de ensaio, foi necessária a construção de um dispositivo para içamento e transporte (figuras 4.19 a 4.23).

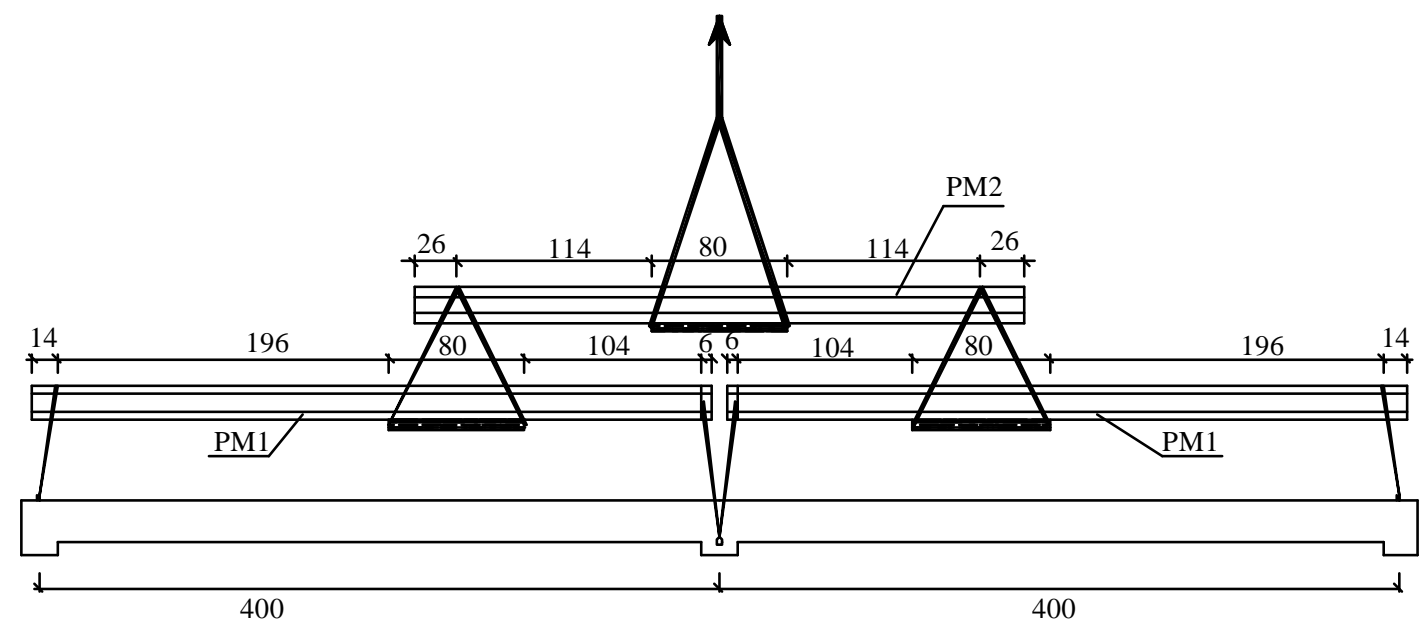

Vista lateral

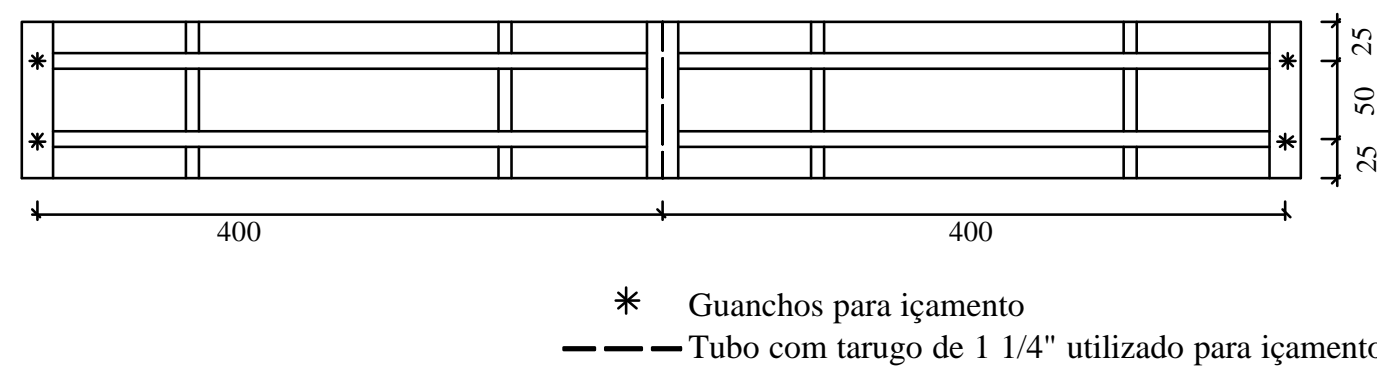

Vista superior

FIGURA 4.19- Esquema geral para içamento e transporte das faixas de lajes - dimensões $\mathrm{em} \mathrm{cm}$

O dispositivo de içamento é basicamente composto por vigas de aço, correntes e cintas de tecido unidos de tal maneira com a laje que, ao serem içados, os esforços que surgem nas lajes são iguais àqueles quando elas se encontram na posição definitiva de ensaio.

As lajes foram içadas pelas vigas de apoio de modo que, nos apoios de extremidade foram utilizados ganchos e no apoio interno foi utilizado um tarugo de aço com de diâmetro de 1 1/4" passando pelo interior da viga. A opção em utilizar o 
tarugo de aço no apoio interno está fundamentada em evitar perturbações nesta região, uma vez que ela é o foco principal do estudo neste trabalho.

Para o içamento e transporte dos modelos foram utilizados dois perfis laminados de 4 " $x 11,4 \mathrm{~kg} / \mathrm{m}$ com $4 \mathrm{~m}$ de comprimento cada (perfil metálico PM1) e um perfil soldado com dimensões $150 \mathrm{~mm} \times 150 \mathrm{~mm}$, espessuras de mesas e alma com, respectivamente, $8 \mathrm{~mm}$ e $6,3 \mathrm{~mm}$ e comprimento total de $360 \mathrm{~m}$ (perfil metálico PM2) conforme podem ser identificados na figura 4.19.

No cálculo para verificação dos perfis metálicos utilizados no içamento e transporte, deveria estar garantido o espaçamento de $80 \mathrm{~cm}$ entre as extremidades das cintas conforme medidas apresentadas na figura 4.19. Então, foram devidamente posicionados e fixados aos perfis metálicos pedaços de madeiras com $80 \mathrm{~cm}$ de comprimento, evitando o deslizamento das cintas e permitindo um posicionamento mais rápido e preciso. Na figura 4.23 pode ser visto este detalhe.

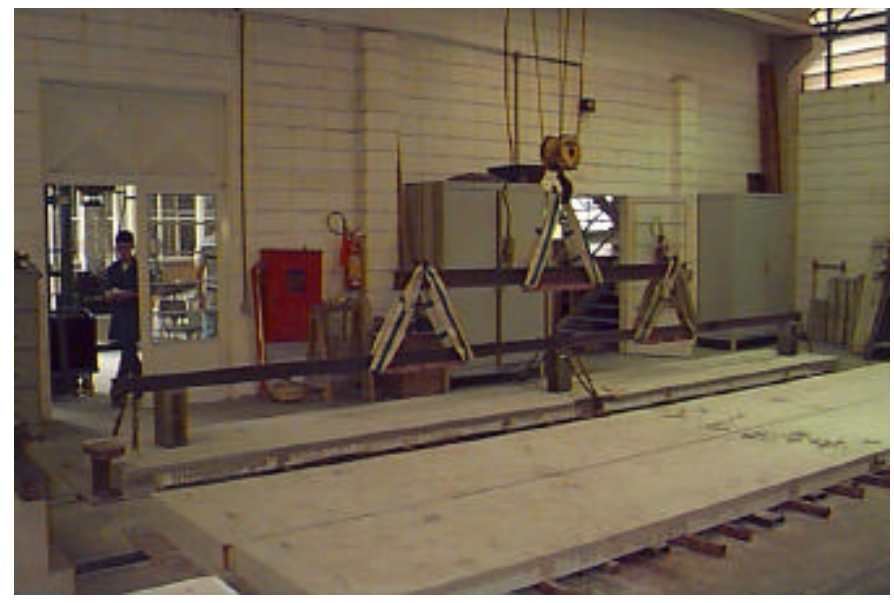

FIGURA 4.20 - Estrutura pronta para ser içada

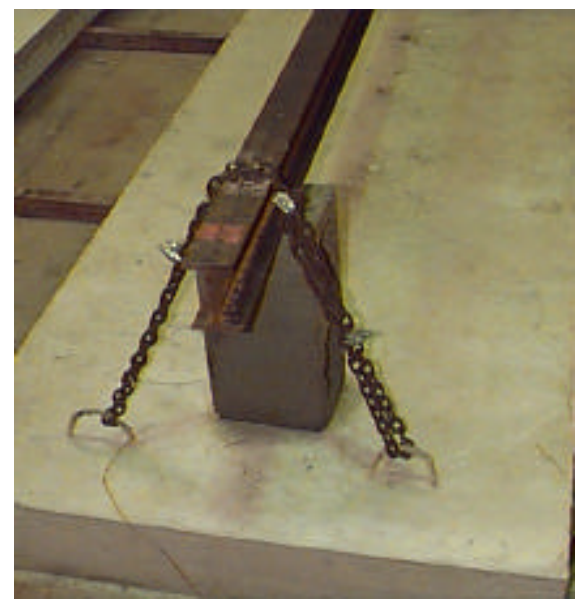

Apoio externo

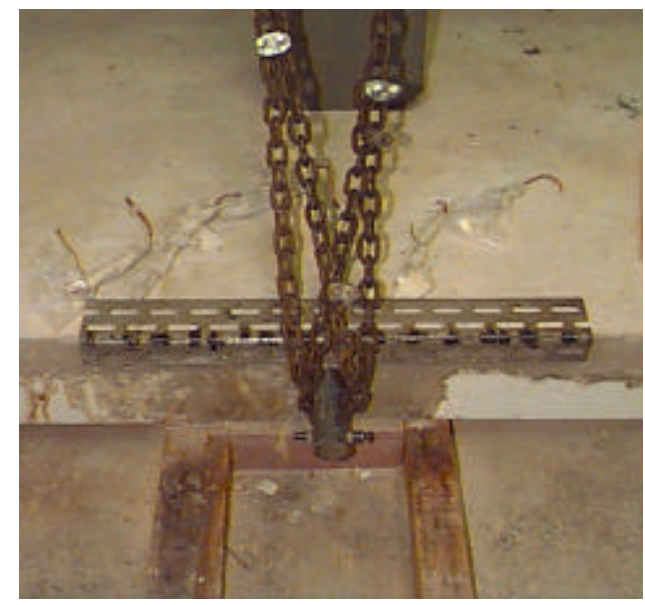

Apoio central

FIGURA 4.21 - Detalhes da ligação das lajes com a estrutura de içamento 

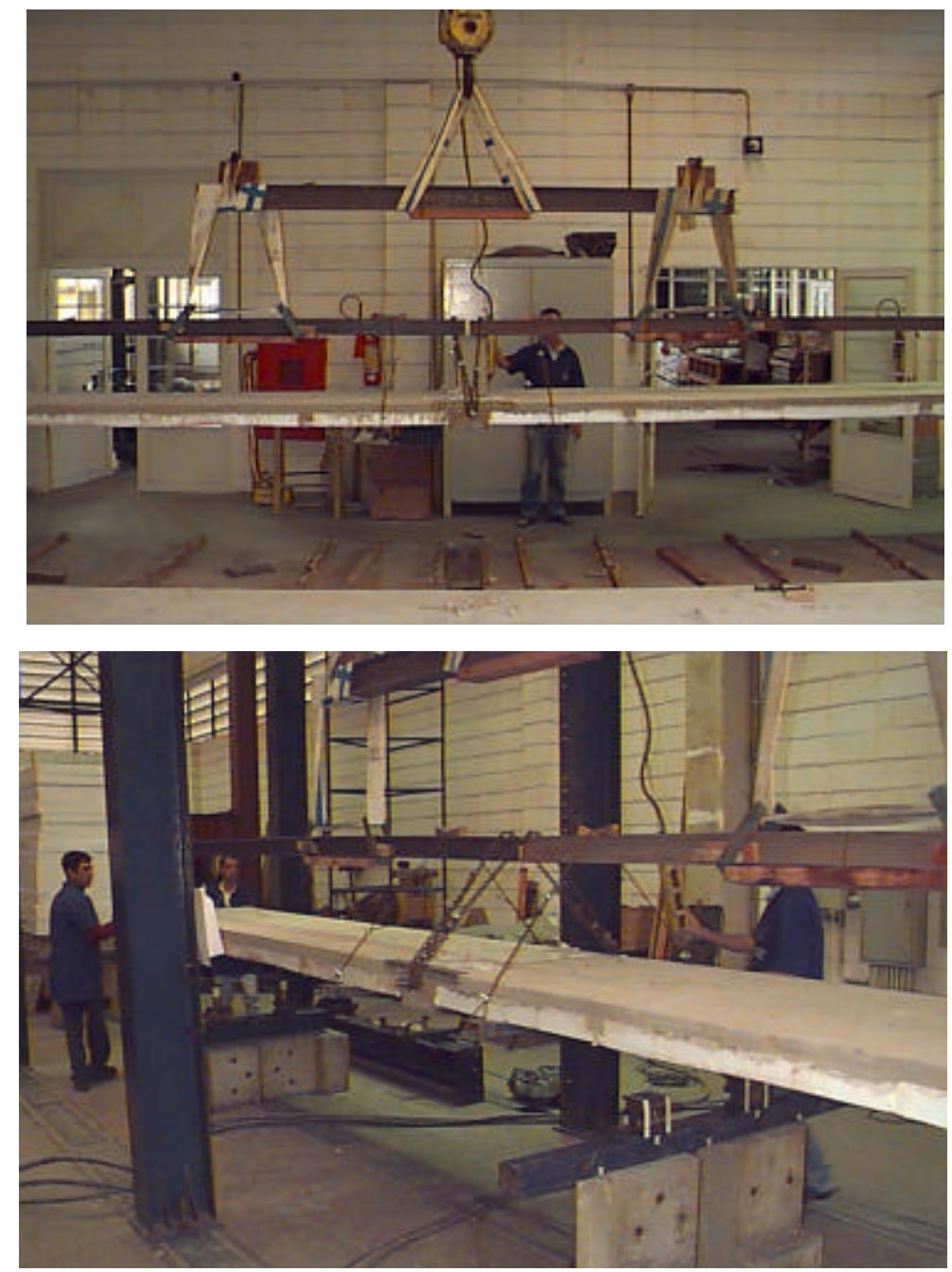

FIGURA 4.22 - Içamento e colocação da estrutura na posição de ensaio

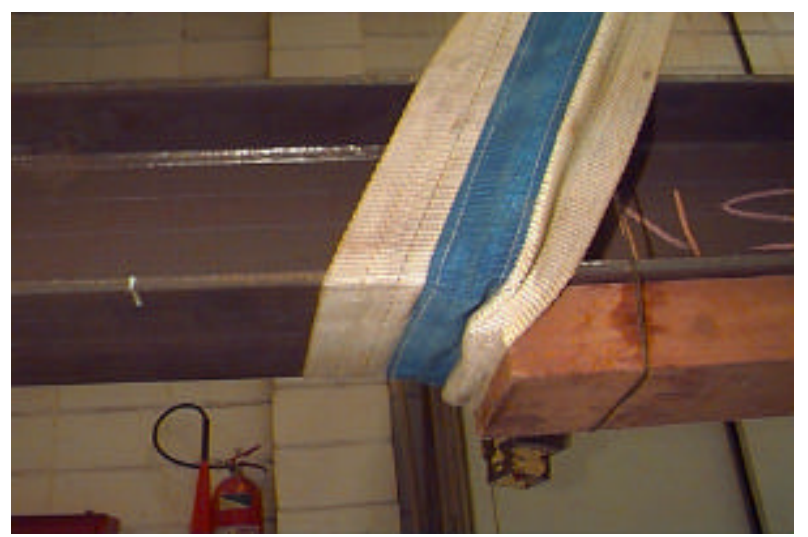

FIGURA 4.23 - Detalhe da fixação da cinta ao perfil metálico 


\subsubsection{Instrumentação}

Os deslocamentos foram medidos por meio de transdutores de deslocamentos dispostos nas lajes conforme mostram as figuras 4.24 e 4.25. Além de medir os deslocamentos em diversos pontos ao longo do elemento estrutural, ainda é possível calcular a curvatura média sobre o apoio intermediário a partir dos deslocamentos dos transdutores R2 a R6.

As forças foram aplicadas por dois atuadores hidráulicos e, para controlar a intensidade destas forças, foram acopladas células de carga aos atuadores. Outras duas células de carga foram posicionadas sob o apoio central de modo a retirar a reação hiperestática e, assim, ser possível avaliar a evolução dos momentos fletores (figuras 4.26).

Foram posicionados extensômetros na região do apoio central de modo a avaliar as deformações nas armaduras e no concreto. No local onde ocorrerá o máximo valor do momento fletor positivo (a $1 \mathrm{~m}$ do eixo dos apoios de extremidade) foram colocados extensômetros nos banzo superior e inferior da armação treliçada (figura 4.29). A distribuição dos extensômetros pode ser vista nas figuras 4.28 e 4.30 .
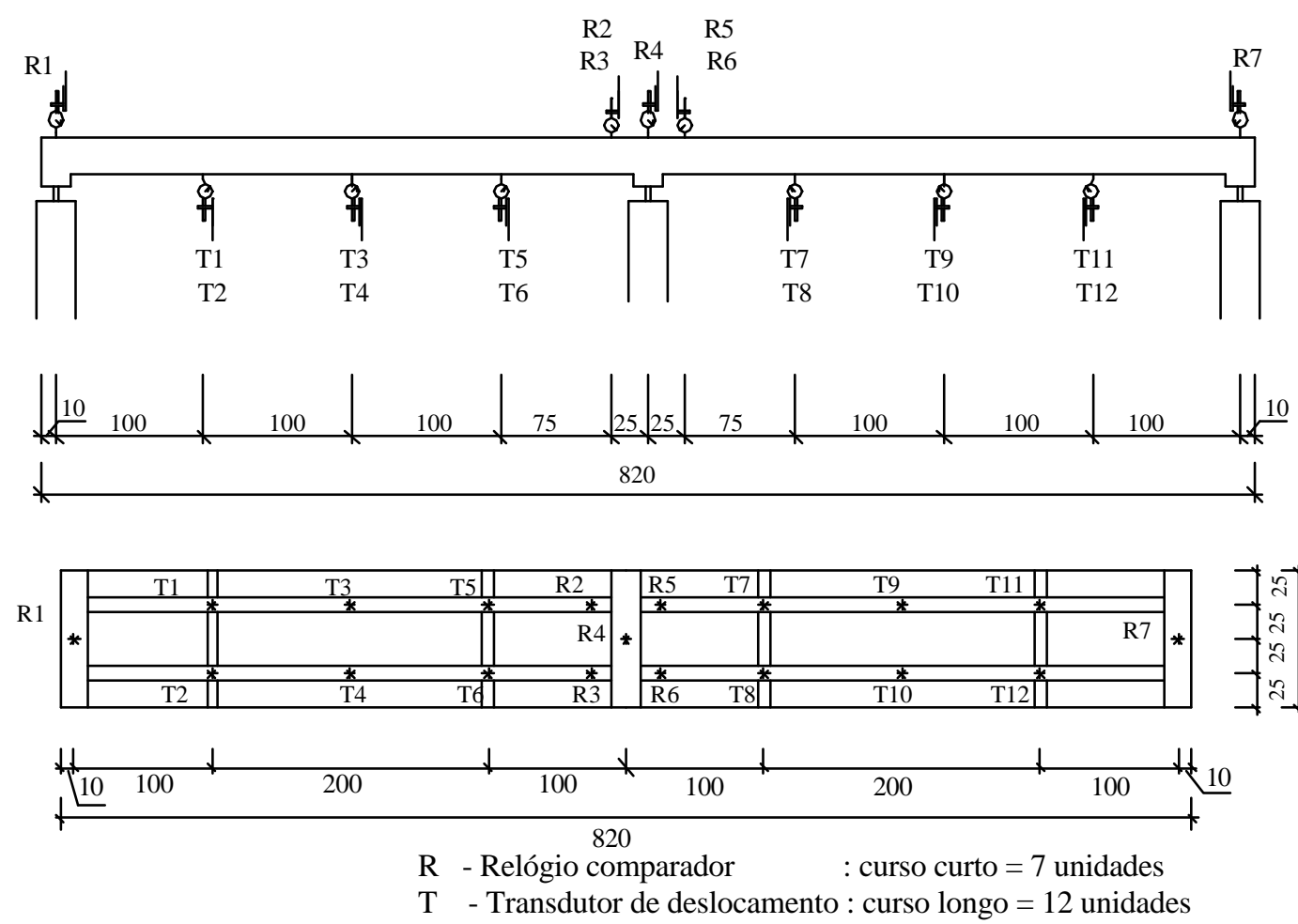

FIGURA 4.24 - Transdutores de deslocamentos 


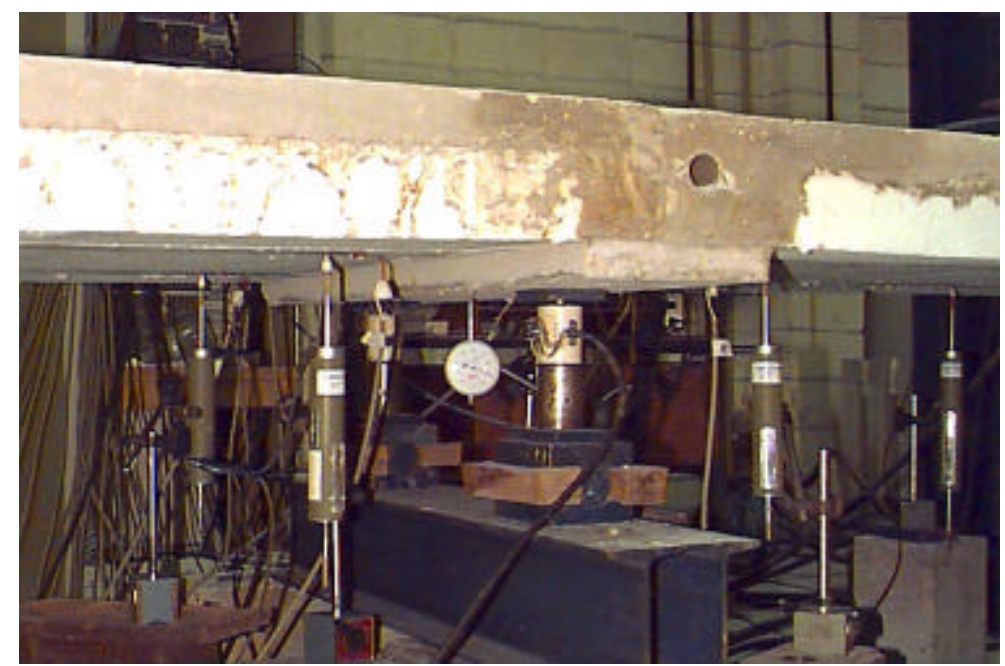

FIGURA 4.25 - Transdutores de deslocamentos e células de carga na região do apoio central

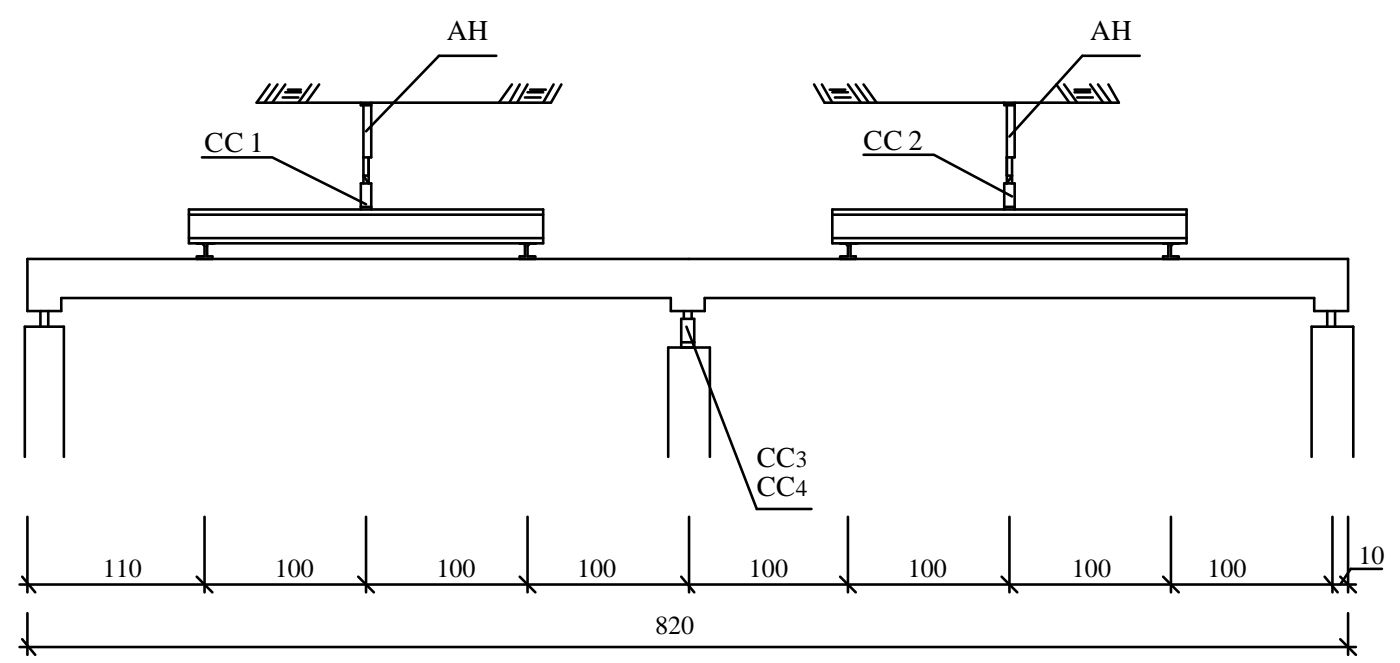

Vista lateral

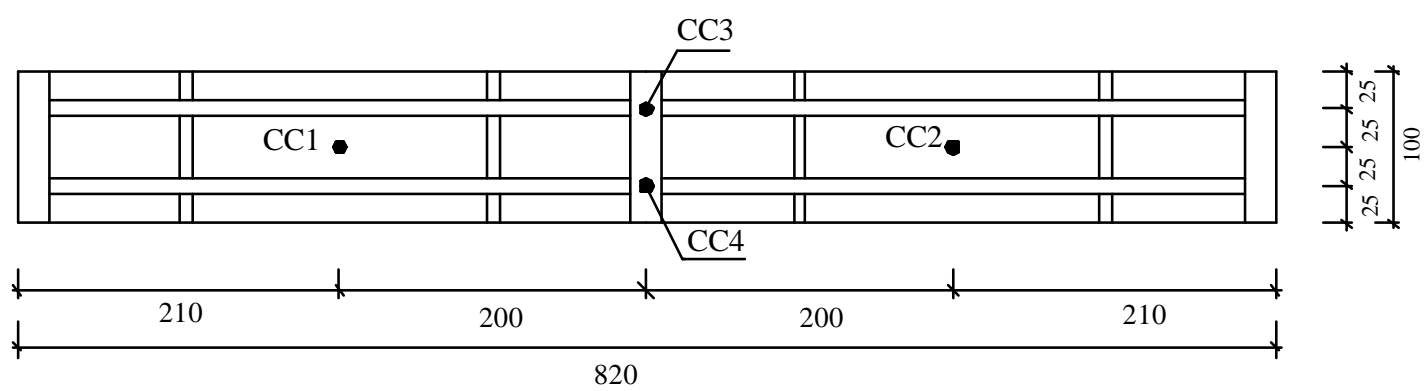

CC - Célula de carga: 4 unidades com capacidade de 10 tf cada $\mathrm{AH}$ - Atuadores hidráulicos: 2 unidades

\section{Vista superior}

FIGURA 4.26 -Atuadores hidráulicos e células de carga 


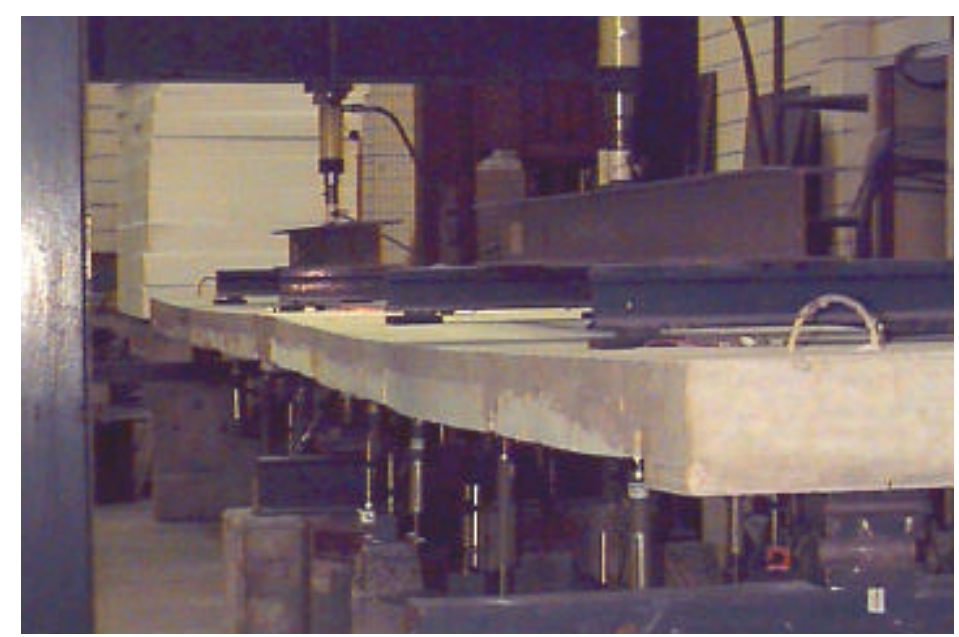

FIGURA 4.27 - Transdutores de deslocamento, atuadores hidráulicos e células de carga estrutura em carga

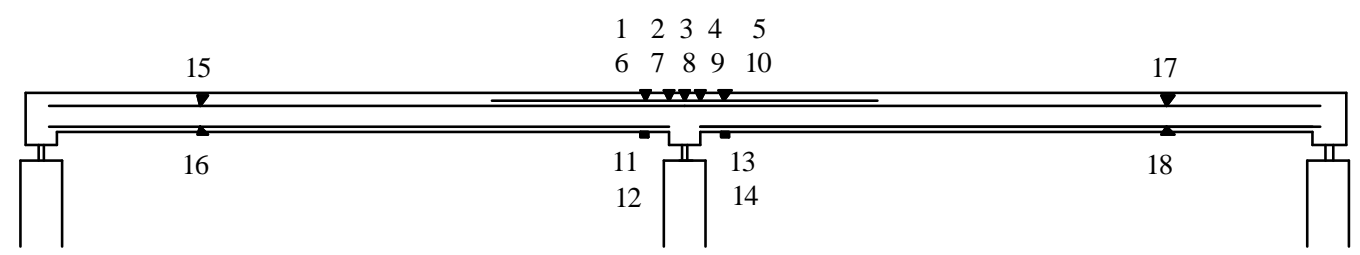

Vista lateral do modelo

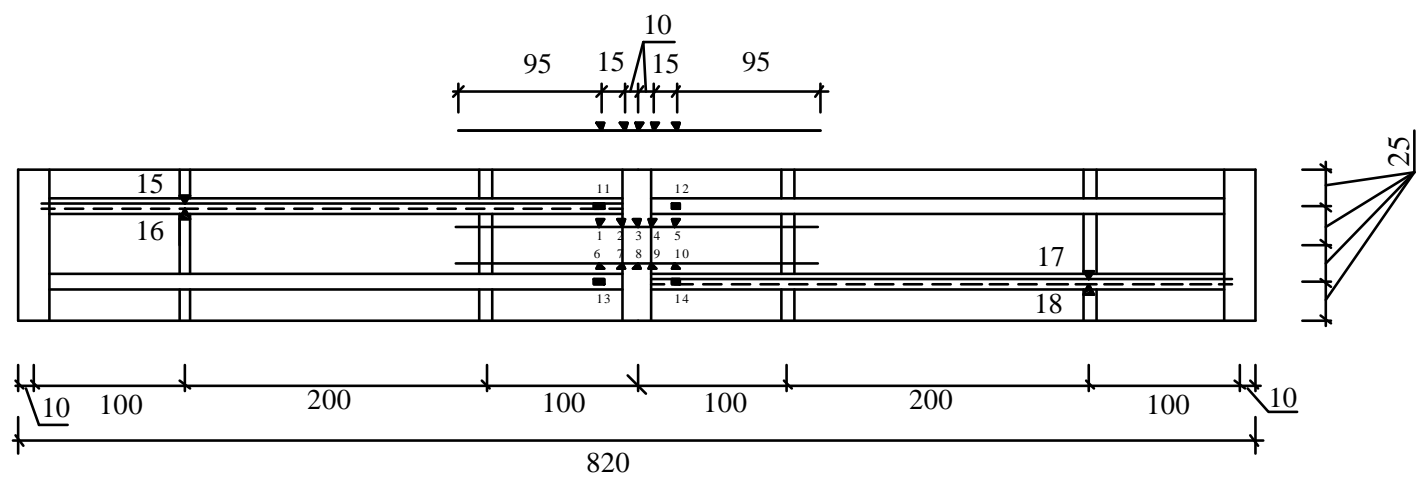

Vista superior do modelo

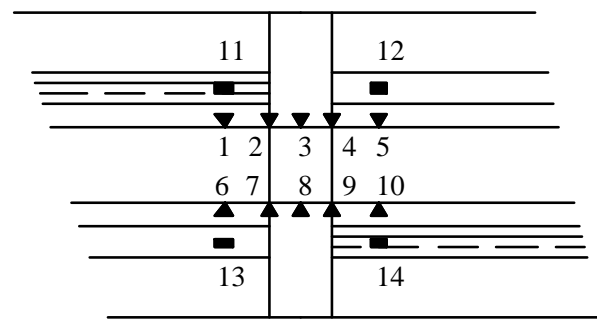

$\boldsymbol{\nabla}$ Extensômetro no aço - 14 unid./modelo

- Extensômetro no concreto - 4 unid./modelo

Detalhe da instrumentação dos extensômetros no apoio

FIGURA 4.28 - Posicionamento dos extensômetros nas faixas de lajes 
Os modelos foram construídos com apoios móveis nas extremidades e o apoio central fixo. Com esta vinculação de apoios, os modelos apresentariam um comportamento real de simetria mais representativo em relação a forças e deslocamentos do que nos casos em que os apoios possuem outro tipo de vinculação. Além do mais, permite que os modelos apresentem grandes deslocamentos com a não ocorrência de forças horizontais decorrentes de um possível comportamento de membrana.

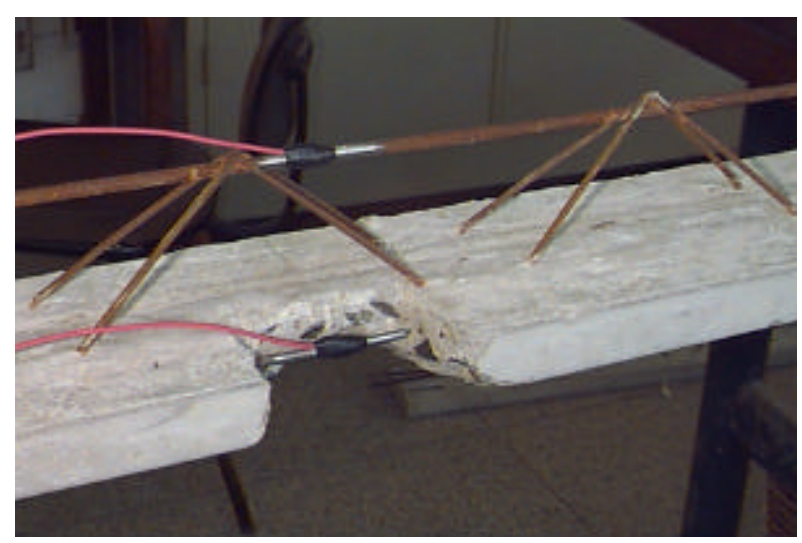

FIGURA 4.29 - Instrumentação da armadura da vigota pré-moldada no ponto de máximo momento fletor positivo

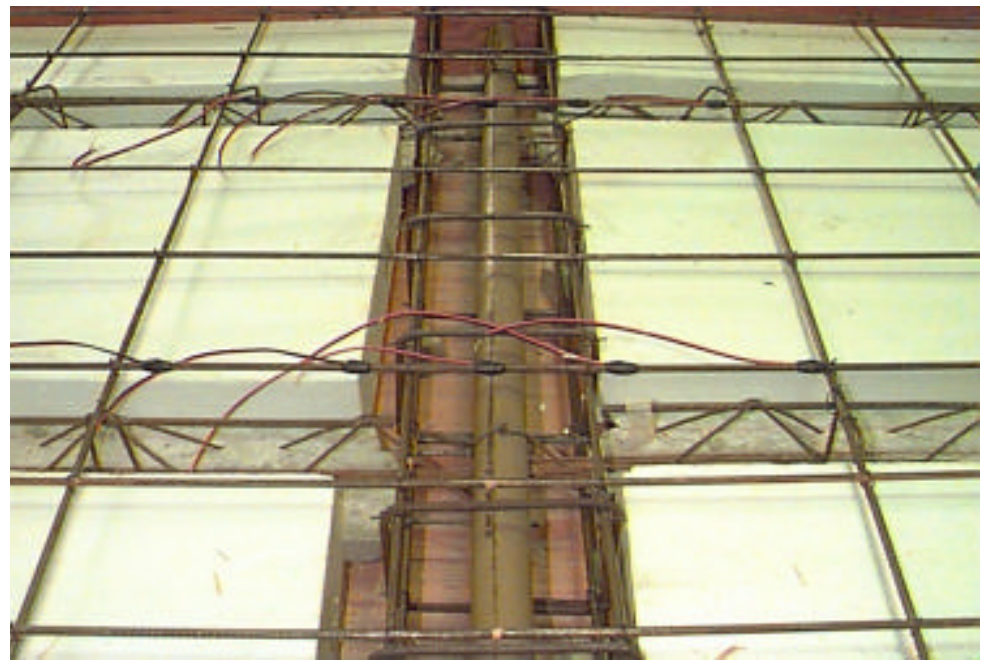

FIGURA 4.30 - Panorama da instrumentação da armadura negativa - modelo M15

De acordo com a numeração dos extensômetros mostrados na figura 4.28, a instrumentação foi realizada da seguinte maneira:

$>\quad$ os extensômetros 1 a 10 estavam posicionados na armadura negativa; 
os extensômetros 11 a 14 estavam posicionados no concreto pré-moldado a $15 \mathrm{~cm}$ da face da viga do apoio interno;

$>\quad$ os extensômetros 15 e 17 foram colocados no banzo superior da armação treliçada;

os extensômetros 16 e 18 foram colocados no banzo inferior da armação treliçada.

As aberturas de fissuras foram medidas por comparação visual entre a fissura presente no modelo e uma escala de abertura de fissuras existentes na régua graduada. Por questões de segurança, somente as aberturas de fissuras sobre o apoio interno foram medidas.

No quadro 1 pode ser encontrado o resumo da instrumentação realizada em cada um dos modelos ensaiados:

QUADRO 1 - Resumo da instrumentação

\begin{tabular}{|c|c|c|c|}
\hline Modelo & Células de carga & $\begin{array}{c}\text { Transdutores de } \\
\text { deslocamentos }\end{array}$ & Extensômetros \\
\hline M15 & \multirow{3}{*}{$\begin{array}{l}4 \text { células de } \\
100 \mathrm{kN} \text { cada - } \\
\text { figura } 4.26\end{array}$} & \multirow{3}{*}{19 - figuras 4.24} & $\begin{array}{c}14-\text { na armadura } \\
4-\text { no concreto }\end{array}$ \\
\hline M40 & & & \multirow[t]{2}{*}{$\begin{array}{c}\text { distribuídos } \\
\text { conforme figuras } \\
4.28\end{array}$} \\
\hline Mac & & & \\
\hline
\end{tabular}

\subsubsection{Procedimentos de ensaio}

A forma de ensaio adotada neste trabalho foi a do carregamento direto, ou seja, as forças aplicadas nos modelos atuaram de cima para baixo. Decorrente disto, não se considerou a parcela da força referente ao peso próprio na análise dos resultados, uma vez que os valores para forças nas células de carga, deslocamentos e deformações até atuação do peso próprio seriam estimados.

Conforme já comentado, as forças foram aplicadas por 2 atuadores hidráulicos, sendo que a força de cada atuador hidráulico foi distribuída no vão da laje por um perfil metálico com $150 \mathrm{~mm}$ de largura e altura e espessuras de alma e 
mesa com $8,0 \mathrm{~mm}$ e $6,3 \mathrm{~mm}$ respectivamente. O perfil metálico foi apoiado sobre trilhos metálicos e os trilhos estavam sobre aparelhos de apoio tipo elastômero (neoprene). $\mathrm{O}$ detalhe da distribuição das forças dos atuadores hidráulicos pode ser visto na figura 4.31 .

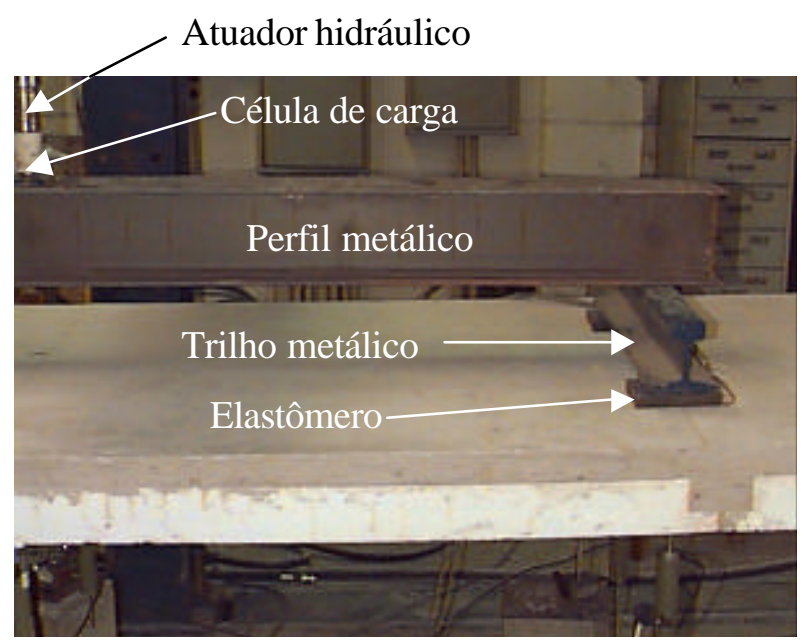

FIGURA 4.31 - Distribuição da força do atuador hidráulico no vão do elemento estrutural

Para a distribuição da força do atuador hidráulico, escolheu-se um perfil que não fosse muito pesado, uma vez que as lajes são muito esbeltas e provocaria a fissuração delas e, também, perfis que não fossem muito leves, pois apresentaria deformações excessivas, comprometendo a distribuição da força do atuador hidráulico.

$\mathrm{Na}$ realização dos ensaios optou-se em não fazer o escorvamento das lajes, isto porque, de acordo com modelo teórico adotado para prever o início da fissuração, qualquer força aplicada pelos atuadores hidráulicos deixariam as faixas de lajes na iminência da fissuração. Como realizar o ensaio com a laje fissurada não seria uma situação desejada, o escorvamento foi suprimido.

Durante o ensaio, à medida que as fissuras iam surgindo eram arquivados em planilha a força atuante em que a fissura aparece e a abertura da fissura medida a partir de uma régua graduada. Continuou-se realizando estas medidas nas etapas seguintes de carga até o instante em que a fissura fosse considerada muito aberta (abertura próxima a $1 \mathrm{~mm}$ ).

Os ensaios terminaram quando não foi mais possível aumentar as forças dos atuadores hidráulicos nos modelos. Portanto, procedeu-se o descarregamento e 
quando não havia mais força aplicada pelo atuador hidráulico, mediu-se a flecha residual que os modelos apresentavam.

\subsection{Caracterização mecânica dos materiais}

\subsubsection{Concreto}

Como as faixas de lajes ensaiadas apresentavam dois tipos de concreto (concreto pré-moldado e concreto moldado in loco) com características diferentes, foi necessário determinar as resistências mecânicas de cada um dos concretos utilizados no modelo.

Para a moldagem dos corpos-de-prova foram utilizadas fôrmas metálicas cilíndricas de $15 \mathrm{~cm} \times 30 \mathrm{~cm}$ (figura 4.32). Os corpos-de-prova do concreto dos elementos pré-moldados foram moldados no momento da sua fabricação. Os corposde-prova do concreto moldado in loco foram moldados no dia da concretagem das faixas de lajes.
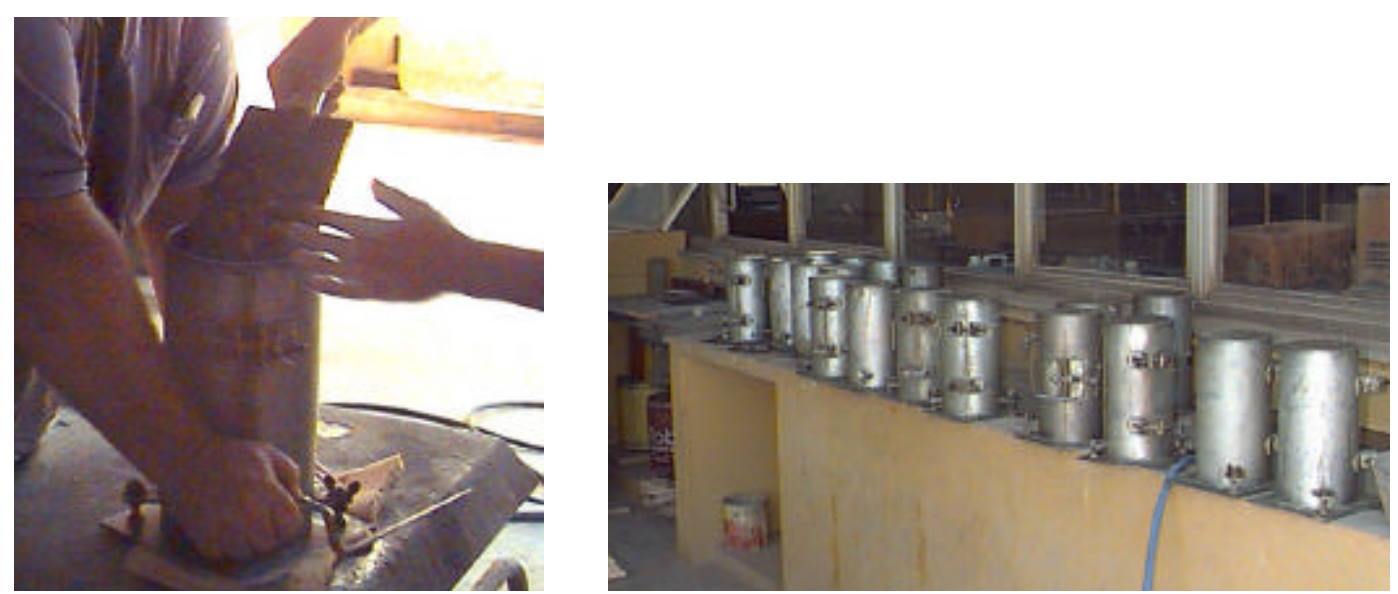

FIGURA 4.32 - Moldagem dos corpos-de-prova

Para a caracterização dos concretos, foram moldados 6 corpos-de-prova para o concreto pré-moldado e 18 corpos-de-prova para o concreto moldado in loco. Do 6 corpos-de-prova do concreto pré-moldado, 3 foram ensaiados à compressão axial e 3 foram ensaiados à tração a partir do ensaio à compressão diametral. Para o concreto moldado in loco, 12 corpos-de-prova foram ensaiados a compressão axial, entretanto, foram aproveitados os resultados dos ensaios de 10 corpos-de-prova. 
Ainda tiveram 4 corpos-de-prova ensaiados à tração e 2 corpos-de-prova ensaiados à compressão axial para se obter o módulo de elasticidade longitudinal do concreto (figura 4.33).

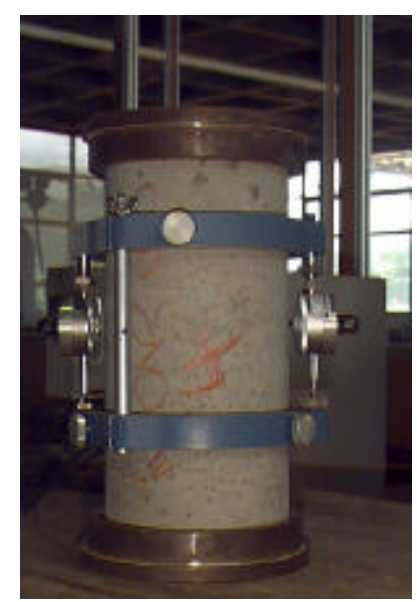

FIGURA 4.33 - Preparação do corpo-de-prova de concreto para ensaio de determinação de módulo de elasticidade

Na tabela 4.2 estão apresentados os resultados dos ensaios em corpos-deprova dos concretos moldado in loco e pré-moldado.

TABELA 4.2 - Propriedades dos concretos

\begin{tabular}{|c|c|c|c|c|c|}
\hline Tipo & $\begin{array}{c}\text { Idade } \\
(\text { dias })\end{array}$ & $\begin{array}{c}\mathbf{f}_{\mathrm{cm}} \\
\mathbf{M P a}\end{array}$ & $\begin{array}{c}\mathbf{f}_{\mathrm{ctm}} \\
\mathbf{M P a}\end{array}$ & $\begin{array}{c}\mathbf{E}_{\mathbf{c}} \\
\mathbf{G P a}\end{array}$ & $\begin{array}{c}\mathbf{E}_{\mathrm{cs}} \\
\mathbf{G P a}\end{array}$ \\
\hline Pré-Moldado & 54 & 38,9 & 2,8 & - & - \\
\hline Moldado in loco & 15 & 21,4 & 2,0 & 25,7 & 24,5 \\
\hline
\end{tabular}

Por conveniência do cronograma de ensaio, todos as faixas de lajes foram concretadas no mesmo dia e ensaiadas com 14, 15 e 16 dias.

\subsubsection{Armaduras}

Foram utilizadas como armadura negativa das faixas de lajes barras lisas de aço com diâmetros nominais de 4,2mm e 6,0mm. Nas figuras 4.34 e 4.35 podem ser vistos os diagramas tensão $x$ deformação, obtida em ensaios à tração em amostras das barras retiradas do aço utilizado. Os ensaios das amostras de barras de aço foram 
realizados no Laboratório de Madeira e Estruturas de Madeira (LaMEM) da EESC USP.

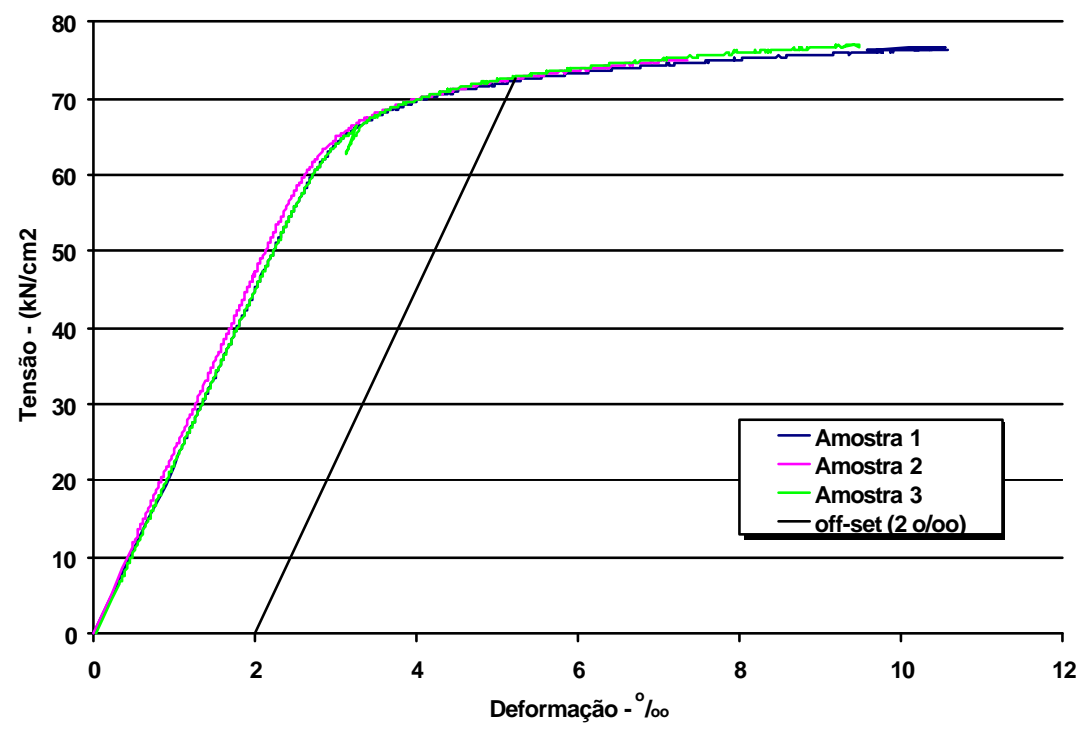

FIGURA 4.34 - Diagrama tensão $x$ deformação das barras com 4,2mm de diâmetro

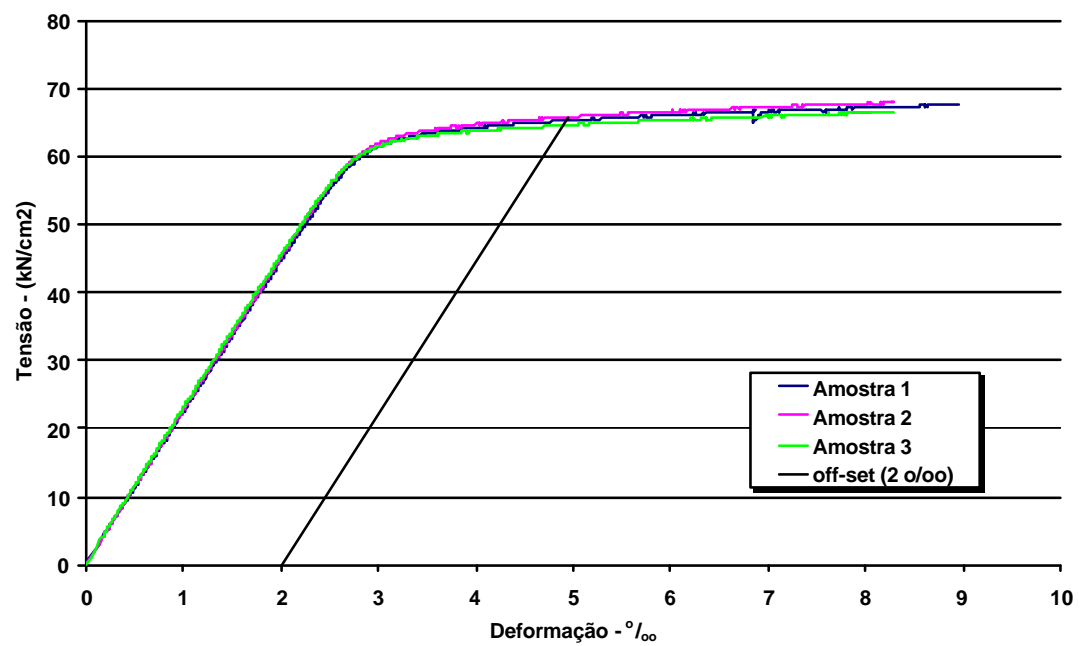

FIGURA 4.35 - Diagrama tensão $x$ deformação das barras com 6,0mm de diâmetro

Na tabela 4.3 são apresentadas as propriedades mecânicas das barras utilizadas como armaduras negativas nas faixas de lajes.

Não foram ensaiadas as barras de aço da armação treliçada e da armadura adicional dos elementos pré-moldados, uma vez que a fábrica que doou as vigotas pré-moldadas não forneceu amostras destes aços para ensaios. 
TABELA 4.3 - Caracterização da armadura negativa

\begin{tabular}{|c|c|c|c|c|c|}
\hline $\begin{array}{c}\boldsymbol{\phi}_{\text {nominal }} \\
\mathbf{m m}\end{array}$ & $\begin{array}{c}\mathbf{A}_{\mathbf{s}} \\
\mathbf{c m}^{\mathbf{2}}\end{array}$ & $\begin{array}{c}\mathbf{E}_{\mathbf{s}} \\
\mathbf{G P a}\end{array}$ & $\begin{array}{c}\mathbf{f}_{\mathbf{y}} \\
\mathbf{M P a}\end{array}$ & $\begin{array}{c}\boldsymbol{\varepsilon}_{\mathbf{y}} \\
\mathbf{o}_{\mathbf{o o}}\end{array}$ & $\begin{array}{c}\mathbf{f}_{\mathbf{u}} \\
\mathbf{M P a}\end{array}$ \\
\hline 4,2 & 0,139 & 229 & 730 & 5,22 & 813 \\
\hline 6,0 & 0,283 & 224 & 660 & 4,95 & 726 \\
\hline
\end{tabular}

\subsection{Resultados dos ensaios}

Neste item são apresentados os resultados obtidos nos ensaios das faixas de lajes. Inicialmente é mostrado o procedimento utilizado na confecção dos diagramas. Posteriormente são montados, a partir do sistema de aquisição de dados, os diagramas de forças por momentos fletores, deslocamentos e deformações na armadura negativa e no concreto. Também é apresentado o panorama da fissuração nas lajes durante o ensaio.

\subsubsection{Procedimentos utilizados na elaboração dos resultados}

\section{a) Forças aplicadas}

Dificilmente os atuadores hidráulicos da figura 4.36 aplicam a mesma força, ao mesmo tempo, nos dois vãos das faixas de lajes, uma vez que os modelos não são perfeitamente simétricos em relação ao apoio central. Portanto, o valor de força utilizado na elaboração de todos os diagramas experimentais será o valor de força concentrada $\mathbf{F}$, obtida a partir da média dos valores das células de carga $\mathrm{CC} 1$ e CC2 fornecidos pelo sistema de aquisição de dados.

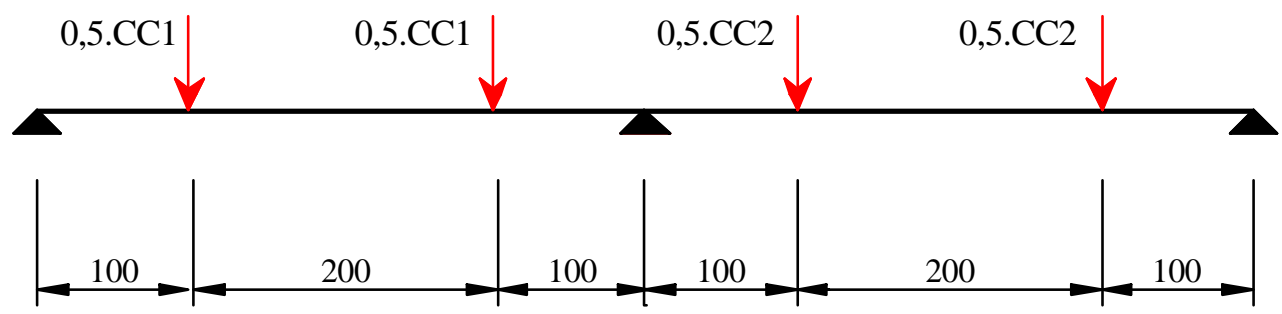

Forças experimentais $(\mathbf{F})=($ Valor de $\mathbf{C C 1}+$ Valor de CC2 $) / 2$

FIGURA 4.36 - Forças atuantes nas faixas de lajes 


\section{b) Momentos fletores}

Inicialmente serão traçados os diagramas de máximos momentos fletores positivos e negativos em função da força atuante. Neste mesmo diagrama também são desenhados os momentos fletores elástico-lineares com rigidez constante nas mesmas seções onde ocorrem os máximos experimentais.

A evolução dos momentos fletores ao longo do eixo longitudinal dos modelos é feita ao longo do eixo x da figura 4.37, onde será tomado partido da simetria dos modelos.

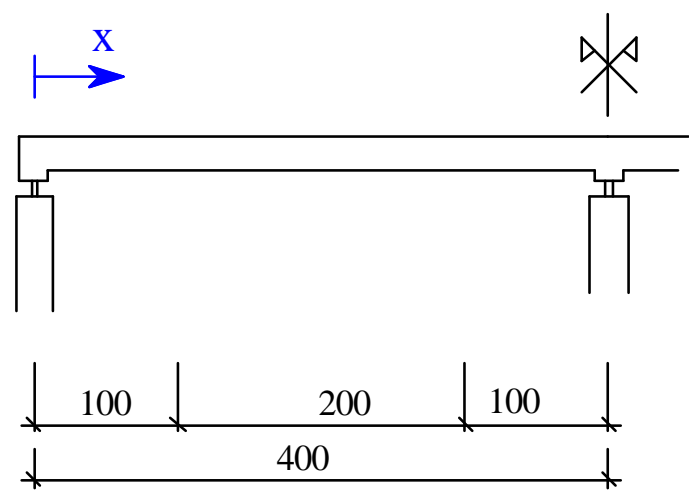

FIGURA 4.37 - Evolução dos momentos fletores ao longo do eixo longitudinal do modelo

\section{c) Deslocamentos}

O diagrama força $x$ deslocamento experimental apresentará três tipos de curvas, equivalente aos deslocamentos na seção do meio do vão, seção a $1 \mathrm{~m}$ do eixo do apoio interno e seção a $1 \mathrm{~m}$ do eixo do apoio interno (figura 4.38).

O deslocamento em cada seção é obtido a partir da média aritmética dos quatro transdutores de deslocamentos correspondentes àquela seção.

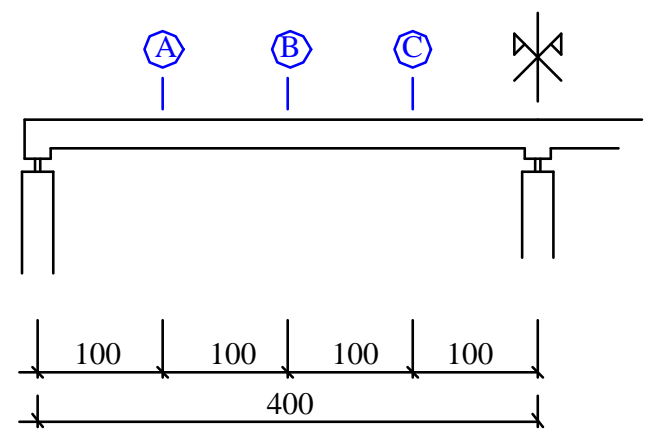

Vista longitudinal
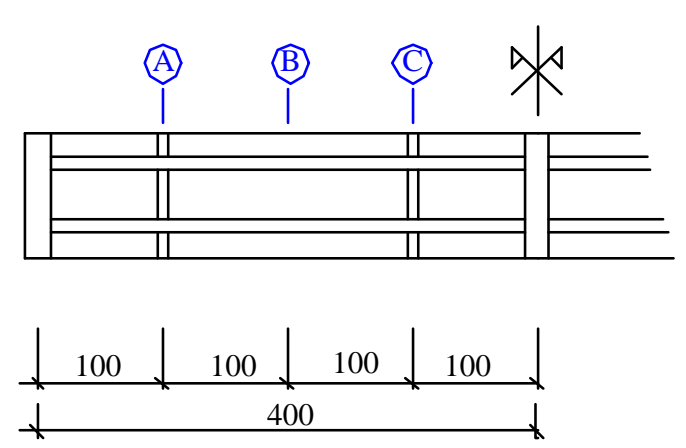

Vista em planta

FIGURA 4.38- Deslocamentos nas seções dos modelos 
Os deslocamentos nas seções da figura 4.38 são obtidos considerando o seguinte procedimento:

A- Deslocamento a $1 \mathrm{~m}$ do eixo do apoio externo - média dos valores de deslocamentos medidos pelos transdutores T1, T2, T11 e T12 mostrados na figura 4.24.

B- Deslocamento no meio do vão - média dos valores de deslocamentos medidos pelos transdutores T3, T4, T9 e T10 mostrados na figura 4.24.

C- Deslocamento a $1 \mathrm{~m}$ do eixo do apoio interno - média dos valores de deslocamentos medidos pelos transdutores T5, T6, T7 e T8 mostrados na figura 4.24 .

\section{d) Deformação na armadura e no concreto}

A convenção utilizada na elaboração dos diagramas força $x$ deformação da armadura negativa está apresentada na figura 4.39. A deformação em cada seção é aquela correspondente à média aritmética dos dados de extensômetros pertencentes àquela seção fornecidos pelo sistema de aquisição de dados.

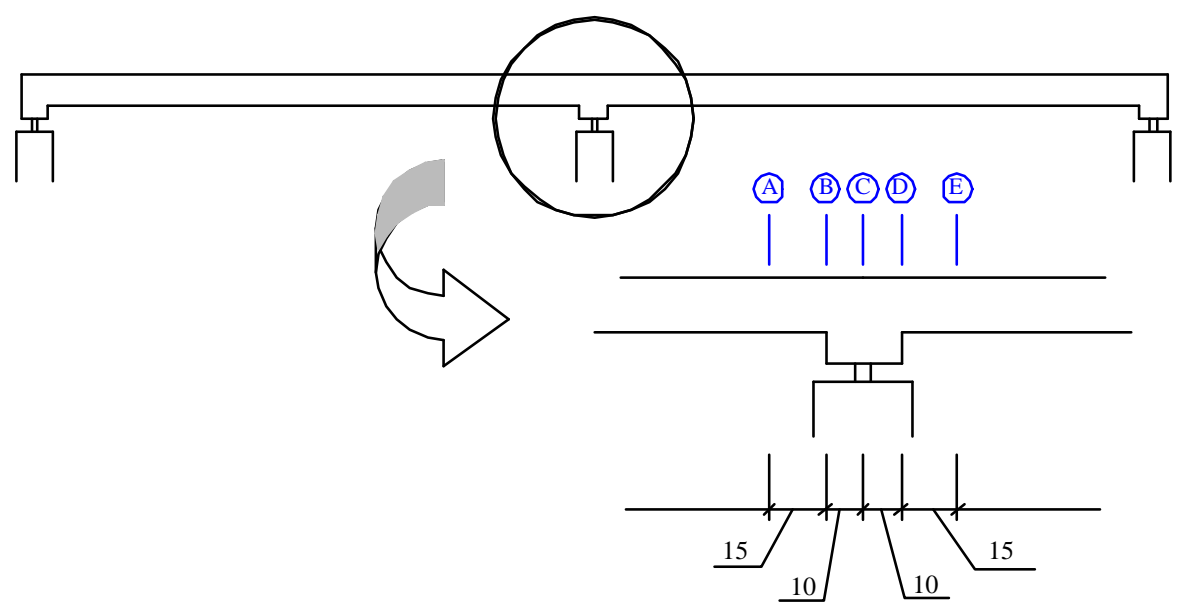

FIGURA 4.39 - Deformações nas seções dos modelos

As deformações nas seções da figura 4.39 são obtidas da seguinte maneira:

A- a $25 \mathrm{~cm}$ do eixo do apoio à esquerda - média dos valores das deformações medidas pelos extensômetros 1 e 6 conforme figura 4.28 
B- na face do apoio à esquerda - média dos valores das deformações medidas pelos extensômetros 2 e 7 conforme figura 4.28

C- no eixo do apoio interno - média dos valores das deformação medidas pelos extensômetros 3 e 8 conforme figura 4.28

D- na face do apoio à direita - média dos valores das deformação medidas pelos extensômetros 4 e 9 conforme figura 4.28

E- a $25 \mathrm{~cm}$ do eixo do apoio à direita - média dos valores das deformação medidas pelos extensômetros 5 e 10 conforme figura 4.28

Os diagramas de deformação do concreto para as seções $\mathbf{A}$ e $\mathbf{E}$ da figura 4.39 são apresentados separadamente na elaboração dos diagramas força $x$ deformação do concreto, a partir das médias dos valores de deformação dos extensômetros 11 e 13 para a seção A e extensômetros 12 e14 para seção E.

\subsubsection{Determinação dos momentos fletores experimentais}

Com os dados obtidos a partir dos valores das células de carga nos modelos, foi possível avaliar a evolução dos momentos fletores a cada incremento de força dado durante o ensaio.

Na figura 4.40, F é o valor médio das células de carga CC1 e CC2 da figura 4.26, obtido a partir do sistema de aquisição de dados e $\mathbf{R}$ é a reação do apoio interno obtida a partir da soma das células de carga CC3 e CC4 da figura 4.26.

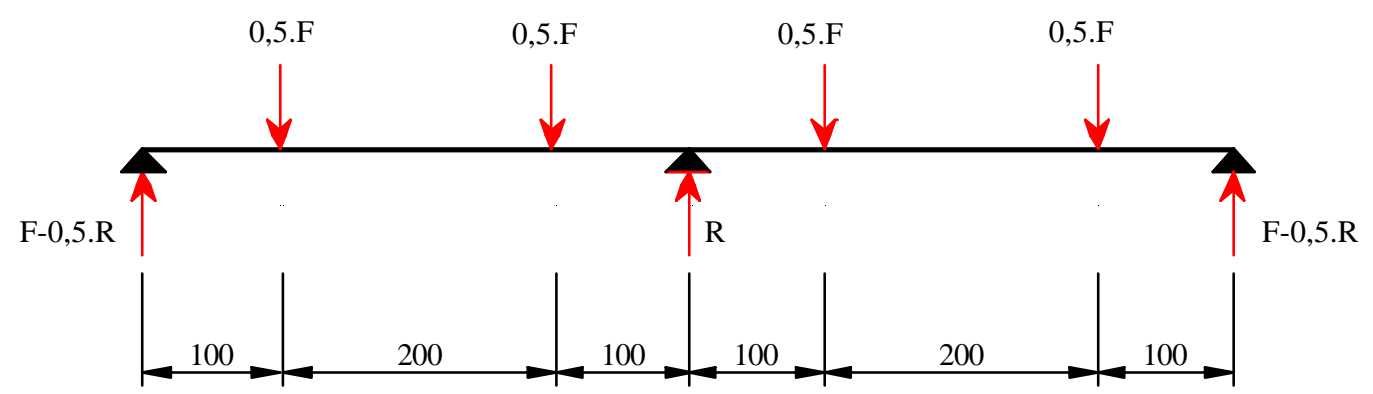

FIGURA 4.40 - Cálculo dos momentos fletores experimentais

A partir da condição de equilíbrio, para cada etapa de carga o diagrama força $x$ momento fletor experimental é obtido a partir da relação da figura 4.41. 


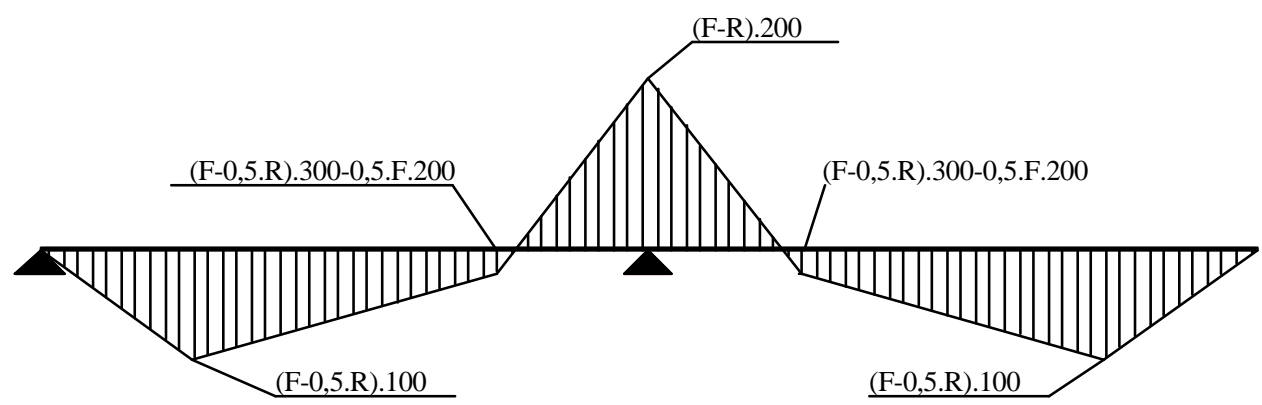

FIGURA 4.41 - Valores de momentos fletores obtidos a partir da aquisição dos dados de ensaio

\subsubsection{Ensaio do modelo M15}

Na figura 4.42 é mostrada a evolução do momento fletor negativo e máximo momento fletor positivo para o modelo M15. Pode ser observado nesta figura que em todas as etapas de carga o momento fletor negativo experimental é maior que o momento fletor negativo obtido pela análise linear e rigidez constante. Como os momentos fletores foram obtidos a partir de condições de equilíbrio, o máximo momento fletor positivo possui valores menores àqueles que seriam obtidos a partir de uma análise linear com rigidez constante. Na figura 4.43 é mostrada a evolução dos momentos fletores experimentais ao longo do eixo longitudinal do modelo M15 em várias etapas de carga.

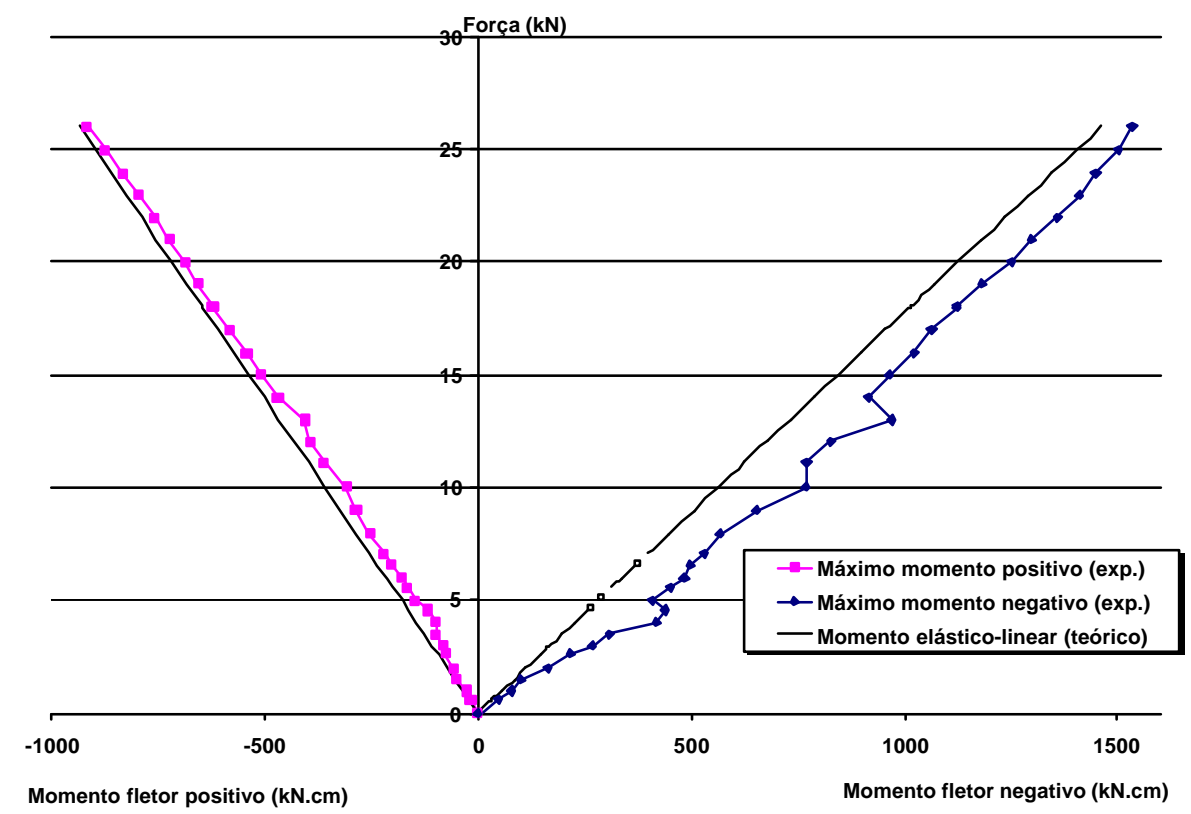

FIGURA 4.42 - Evolução dos máximos momentos fletores positivo e negativo - M15 


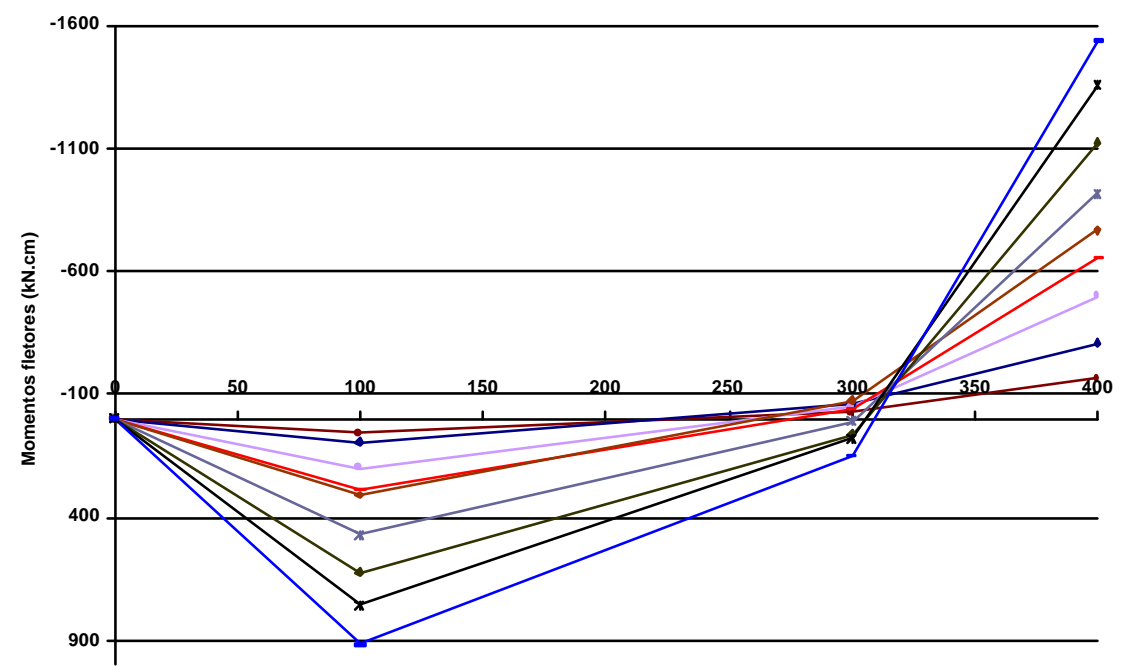

FIGURA 4.43 - Evolução dos momentos fletores experimentais- modelo M15

Constata-se neste ensaio que, embora o dimensionamento desta laje tenha sido realizado a partir do cálculo plástico considerando-se $15 \%$ de redistribuição dos momentos fletores negativos, nenhum dos resultados obtidos no ensaio indica que existiu redistribuição dos momentos fletores negativos.

Na figura 4.44 pode ser observada a evolução dos deslocamentos das seções a $1 \mathrm{~m}$ do eixo do apoio externo, seção do meio do vão e seção a $1 \mathrm{~m}$ do eixo do apoio interno. Verifica-se nesta figura que o deslocamento da seção no meio do vão do elemento foi bem próximo do deslocamento da seção a $1 \mathrm{~m}$ do eixo do apoio intermediário.

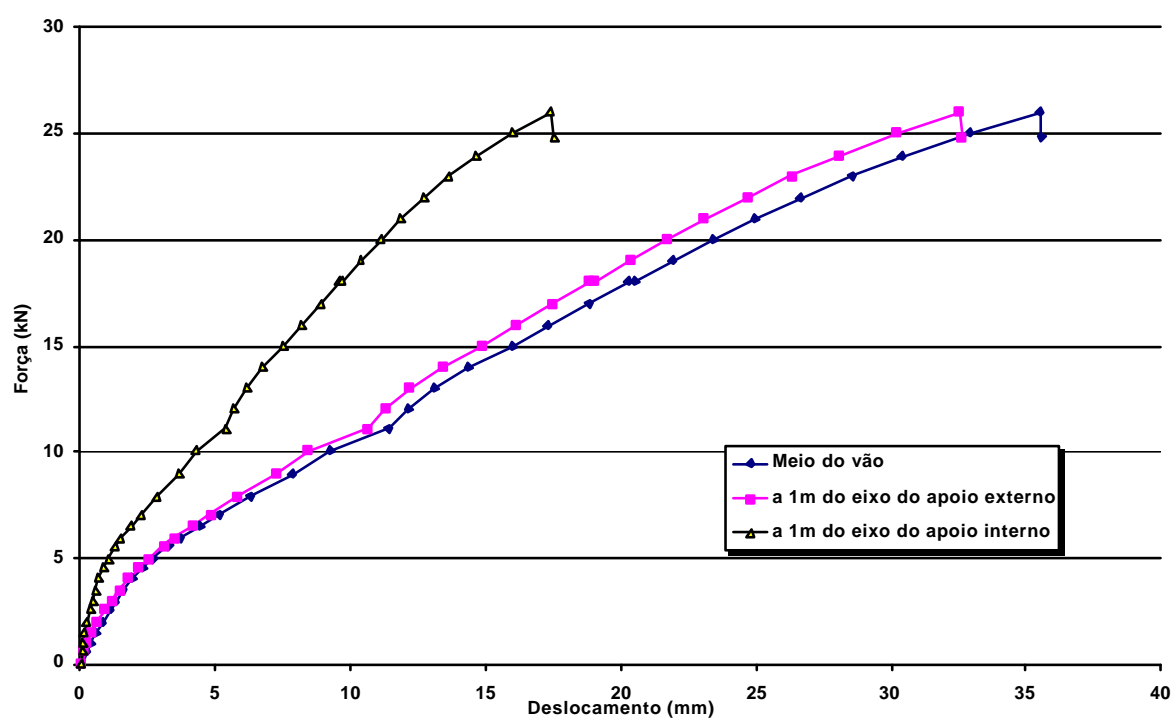

FIGURA 4.44 - Deslocamentos experimentais - M15 
O diagrama força $x$ deformação da armadura negativa pode ser visto na figura 4.45. No primeiro trecho deste diagrama, percebe-se a mudança na inclinação das curvas para uma força aplicada em torno de $5 \mathrm{kN}$. É verificado nas etapas posteriores de carga que o escoamento é atingido, uma vez que a deformação de um dos trechos da barra atingiu deformações superiores a 4,95 \% (deformação de início de escoamento da armadura obtida no ensaio à tração das barras). $\mathrm{O}$ escoamento da barra de aço ocorre num ponto localizado na seção junto a uma das faces da viga de apoio, ou seja, no ponto mais provável de ocorrência de uma rótula plástica.

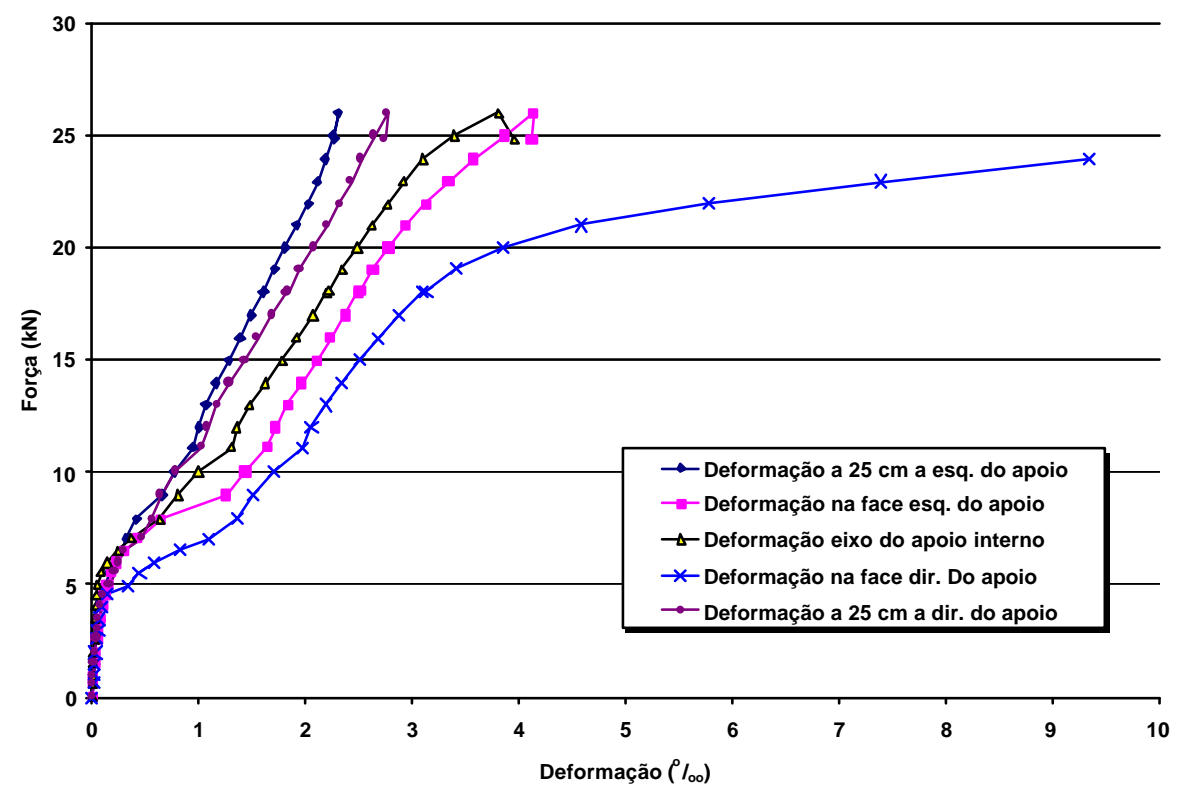

FIGURA 4.45 - Deformações na armadura negativa obtidas no ensaio - M15

Na figura 4.46 é apresentado o diagrama da deformação do concreto com as forças aplicadas. De acordo com esta figura, verifica-se que a deformação no concreto junto ao apoio é sempre crescente, não indicando redistribuição dos momentos fletores negativos.

Este modelo apresentou uma intensa fissuração sobre o apoio central, aparecendo ao todo 8 fissuras distribuídas num trecho de $95 \mathrm{~cm}$. Na figura 4.47 é mostrada uma visão geral da fissuração para o modelo M15, em função da atuação dos momentos fletores negativos. Notar que este modelo apresentou aberturas de fissuras muito pequenas mesmo nas etapas finais de carga. 


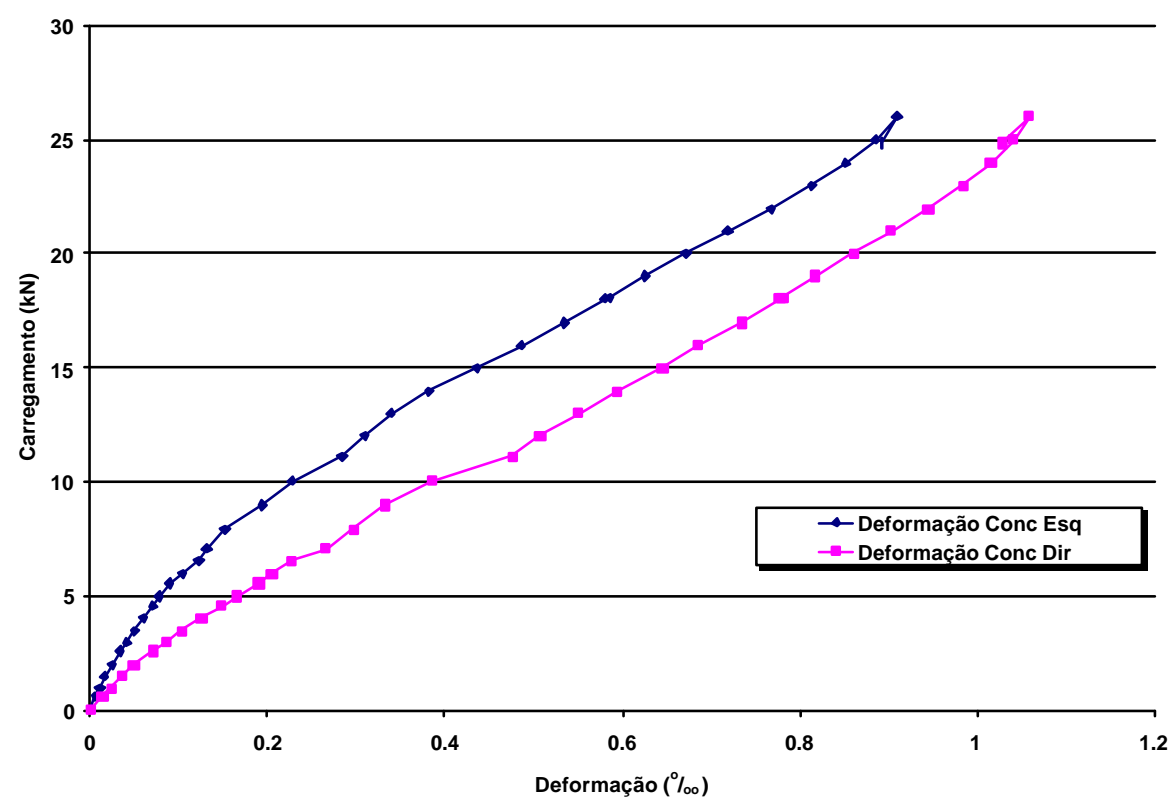

FIGURA 4.46 - Deformações no concreto comprimido obtidas no ensaio - M15

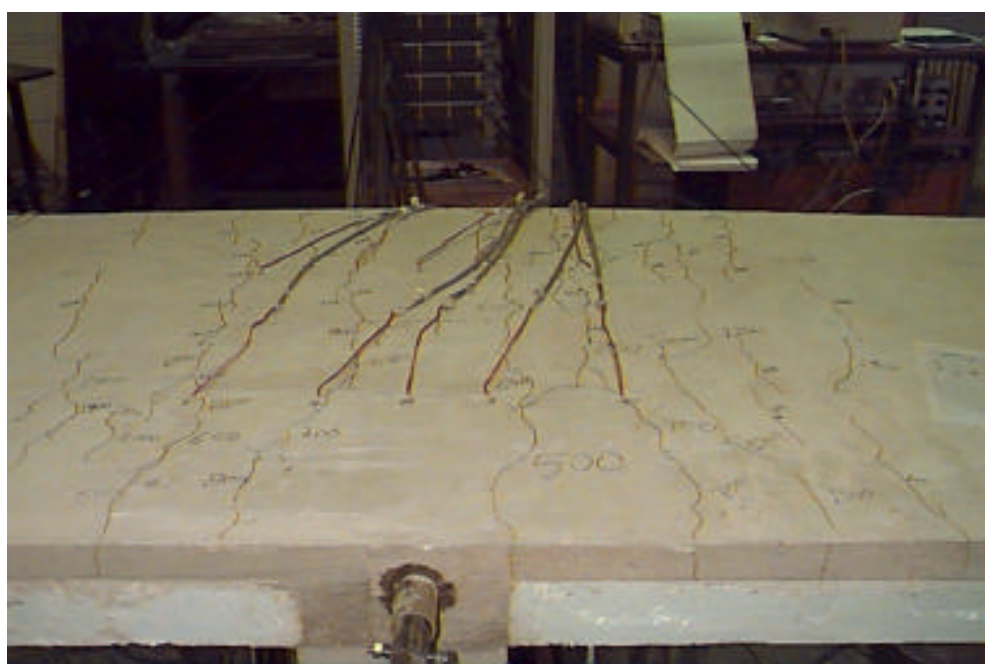

FIGURA 4.47 - Fissuração devido ao momento fletor negativo - modelo M15

Em cada vigota pré-moldada apareceram, em média, 24 fissuras de flexão com espaçamentos de $10 \mathrm{~cm}$. Por comodidade, as aberturas das fissuras que apareceram nas vigotas pré-moldadas não foram medidas. Visualmente estas fissuras apresentaram menores aberturas que as fissuras sobre o apoio central.

De acordo com a definição de rótula plástica apresentada pelo CEB-90 (1991) e apresentado neste trabalho no item 3.5.1-b, o comprimento $\ell_{\mathrm{pl}}$ da rótula plástica do modelo M15 é de aproximadamente $18 \mathrm{~cm}$, correspondente aos pontos nos quais a armadura negativa está em escoamento (figura 4.48). Os diagramas desta 
figura não se mantiveram simétricos em relação à origem por causa dos atuadores hidráulicos terem aplicado mais carga em um dos vãos deste modelo.

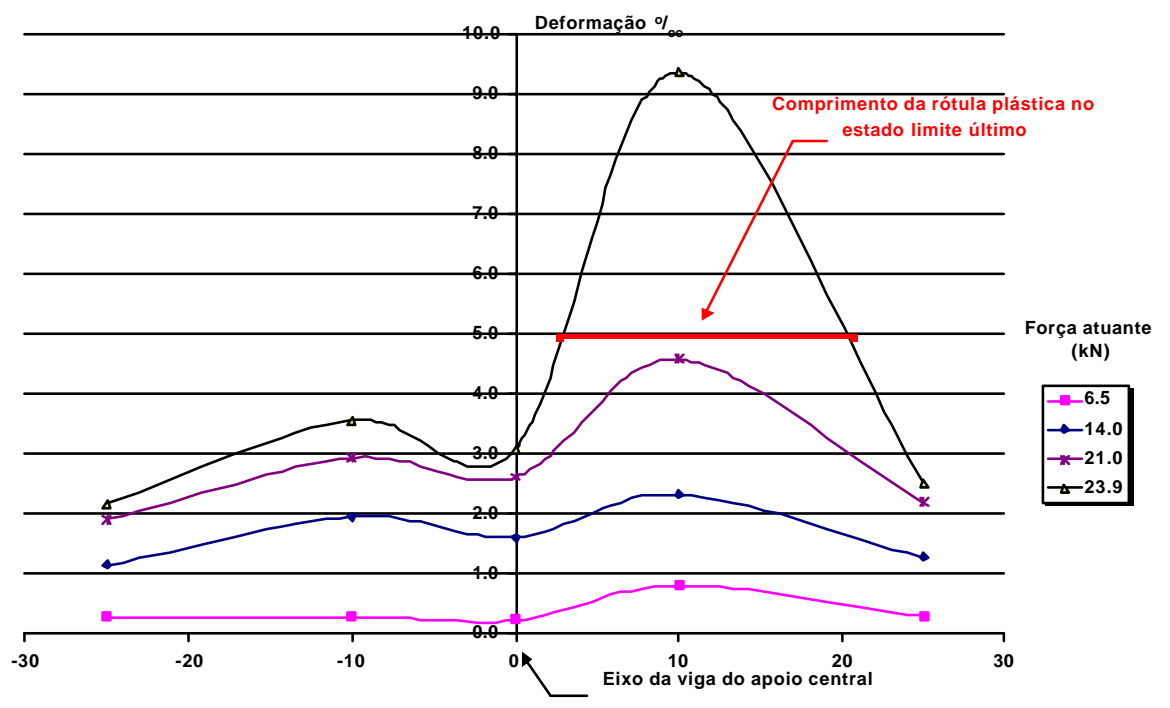

FIGURA 4.48 - Deformações na armadura negativa ao longo do seu eixo - M15

\subsubsection{Ensaio do modelo M40}

A evolução do momento fletor negativo e máximo momento fletor positivo podem ser vistos na figura 4.49. Verifica-se nesta figura que antes de ocorrer a fissuração, o momento fletor negativo experimental é ligeiramente superior ao momento fletor negativo obtido a partir de uma análise linear com rigidez constante. Após a fissuração, ocorre uma queda no valor do momento fletor negativo, voltando a crescer em etapas posteriores de carga. Diferentemente ao modelo M15, após a fissuração os momentos fletores negativos voltam a crescem com valores inferiores aos momentos fletores obtidos com a análise linear e rigidez constante. A partir da força de $15 \mathrm{kN}$, percebe-se uma redistribuição dos momentos fletores negativos mais efetiva.

Na figura 4.50 é mostrada a evolução dos momentos fletores ao longo do eixo longitudinal do modelo M40. Observa-se nesta figura que para as etapas finais de carga os momentos fletores negativo praticamente não crescem, ao passo que os momentos fletores positivos apresentam um acréscimo significante com o aumento da carga. 


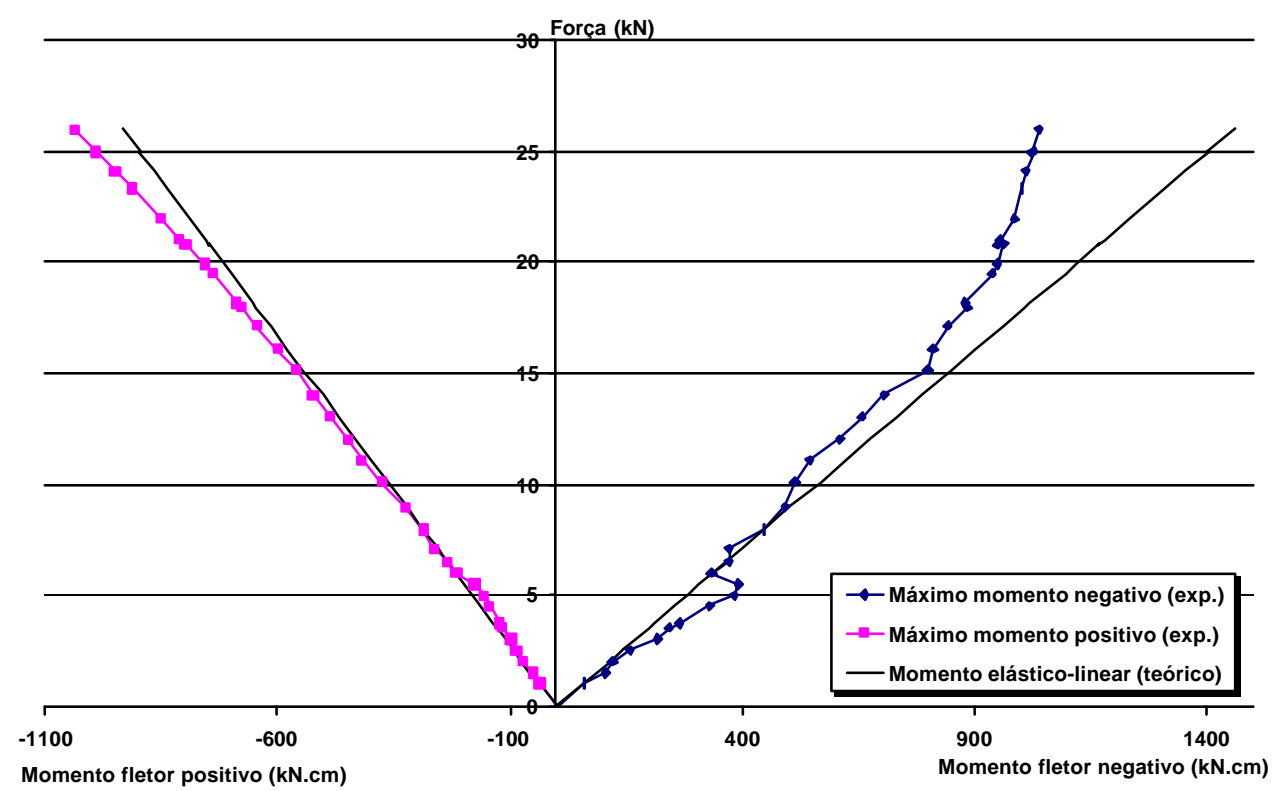

FIGURA 4.49 - Evolução dos máximos momentos fletores positivo e negativo - M40

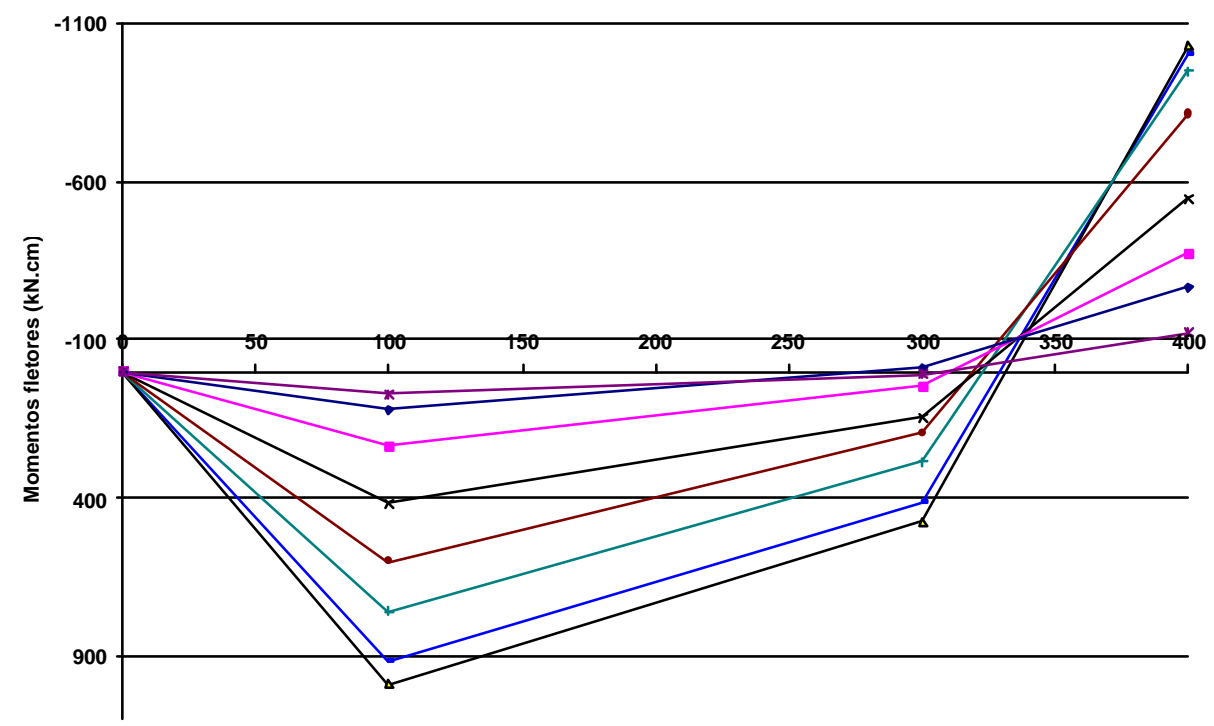

FIGURA 4.50 - Evolução dos momentos fletores de ensaio - modelo M40

$\mathrm{Na}$ figura 4.51 podem ser vistos os deslocamentos nas seções instrumentadas do modelo. É observada uma pequena descontinuidade nos diagrama quando é atingida a carga de fissuração $(5,5 \mathrm{kN})$ 


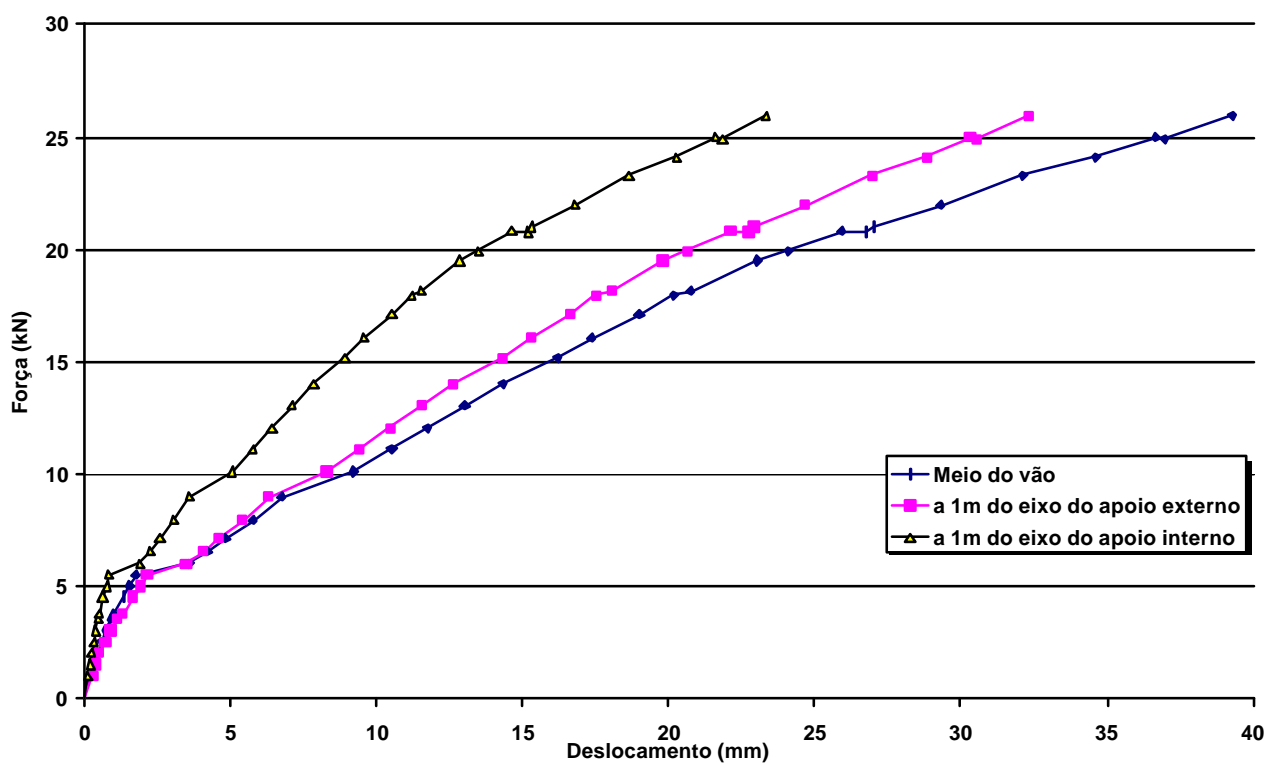

FIGURA 4.51 - Deslocamentos experimentais - M40

As deformações da armadura negativa podem ser vistas na figura 4.52. Para uma força de aproximadamente $5,5 \mathrm{kN}$ observa-se o instante em que a armadura negativa começa a se deformar, uma vez que o concreto se apresenta fissurado. Para uma força superior a $20 \mathrm{kN}$, a armadura negativa apresenta dois pontos em escoamento, pontos estes localizados nas faces da viga do apoio central.

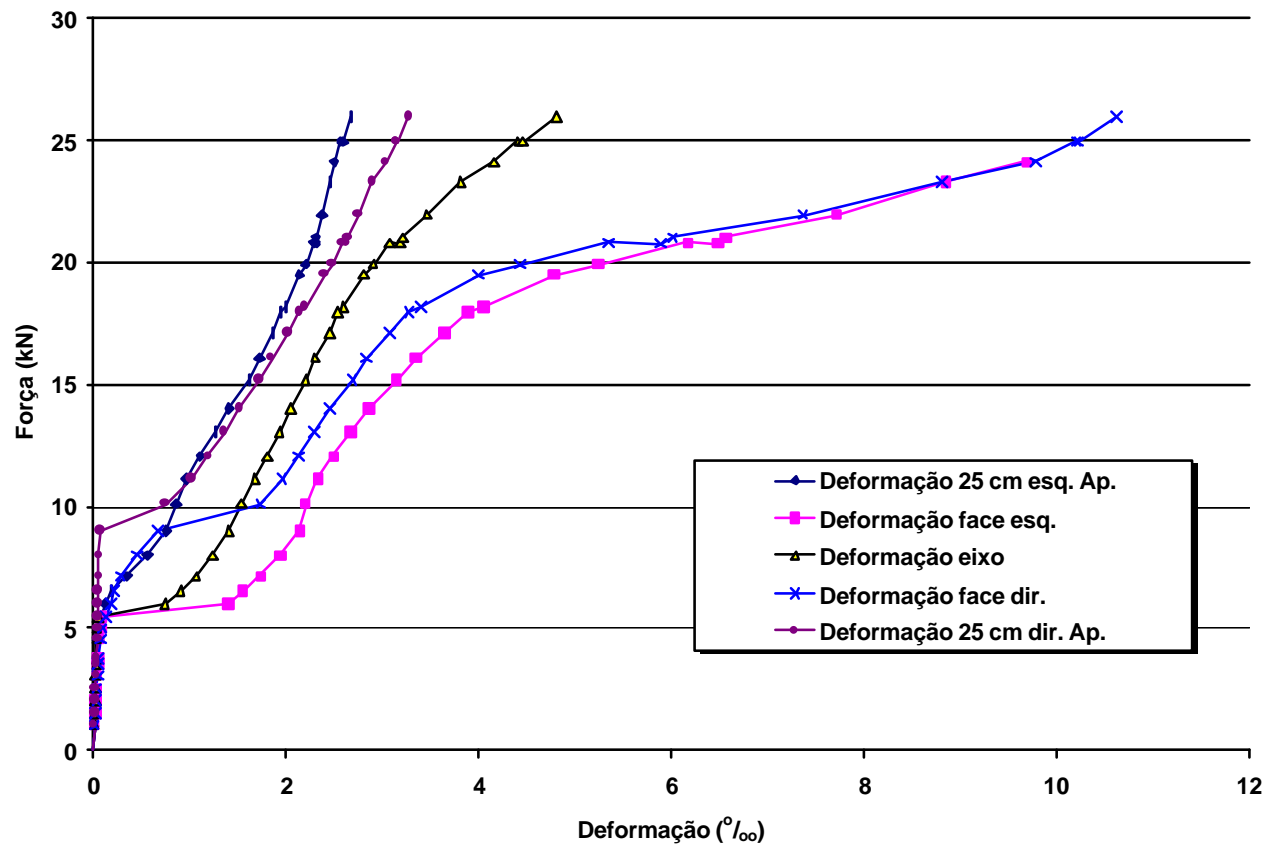

FIGURA 4.52 - Deformação da armadura negativa obtidas no ensaio - M40 
O diagrama da deformação do concreto comprimido com a força aplicada é apresentado na figura 4.53. Para as forças próximas a $5,5 \mathrm{kN}$, percebe-se uma queda na deformação provocada pela físsuração no concreto tracionado, porém, as deformações no concreto voltam a crescer em etapas seguintes de carga. Verifica-se nas etapas finais de carga que a curva tende a regredir, diminuindo as deformações no concreto, indicando a ocorrência da redistribuição dos momentos fletores negativos.

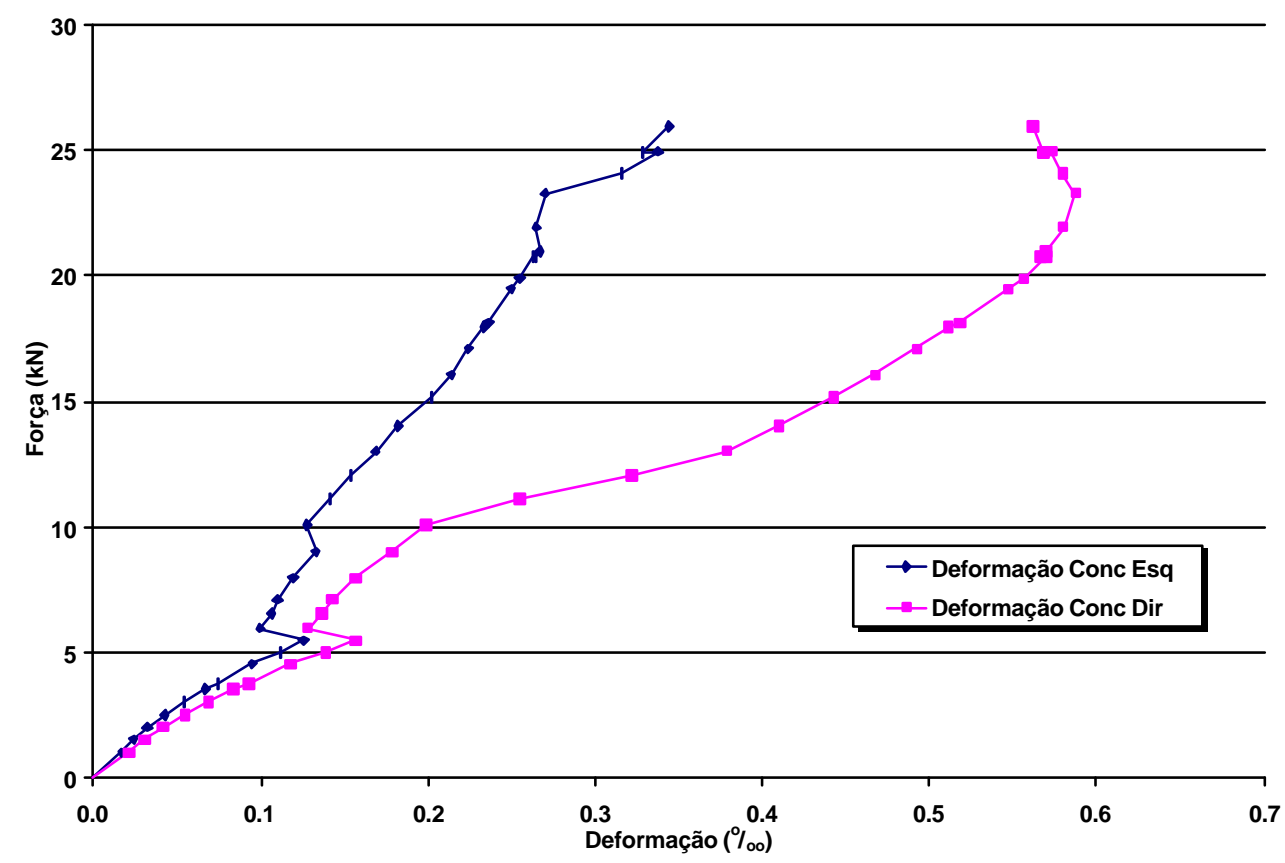

FIGURA 4.53 - Deformações no concreto comprimido obtidas no ensaio - M40

O modelo M40 apresentou apenas duas fissuras principais por causa da atuação dos momentos fletores negativos. Estas fissuras situaram-se aproximadamente nas interfaces entre a viga de apoio interno e a laje nervurada (figura 4.54).
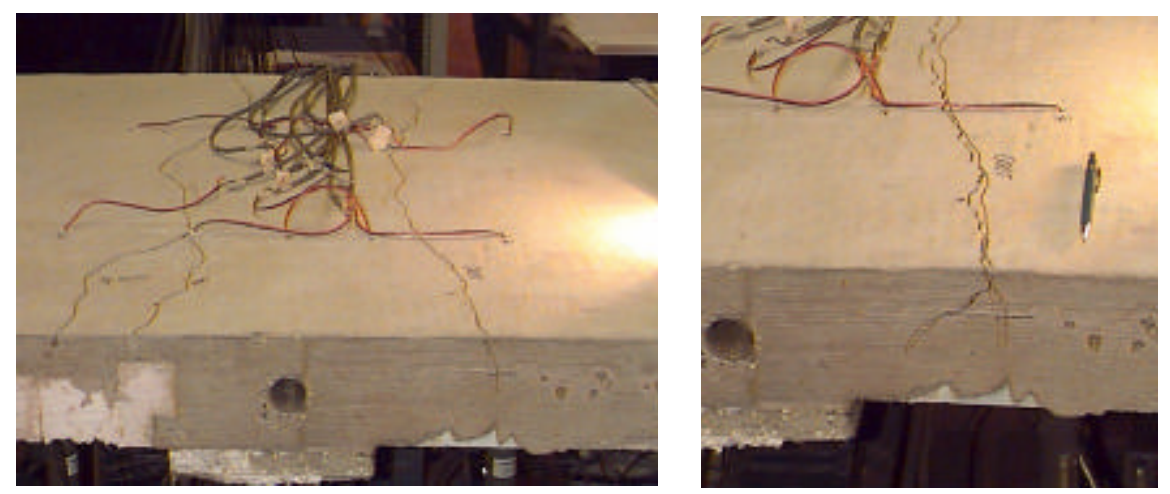

FIGURA 4.54 - Fissuração devido atuação do momento fletor negativo - modelo M40 
À medida que a força aplicada na laje vai aumentando, as aberturas destas fissuras vão ficando cada vez maiores.

Na figura 4.55 pode ser visto o diagrama força $x$ abertura de fissura. Nos diagramas desta figura, duas medidas de aberturas de fissuras foram descartadas, pois seus valores não apresentavam comportamento físico adequado com os demais valores encontrados no ensaio.

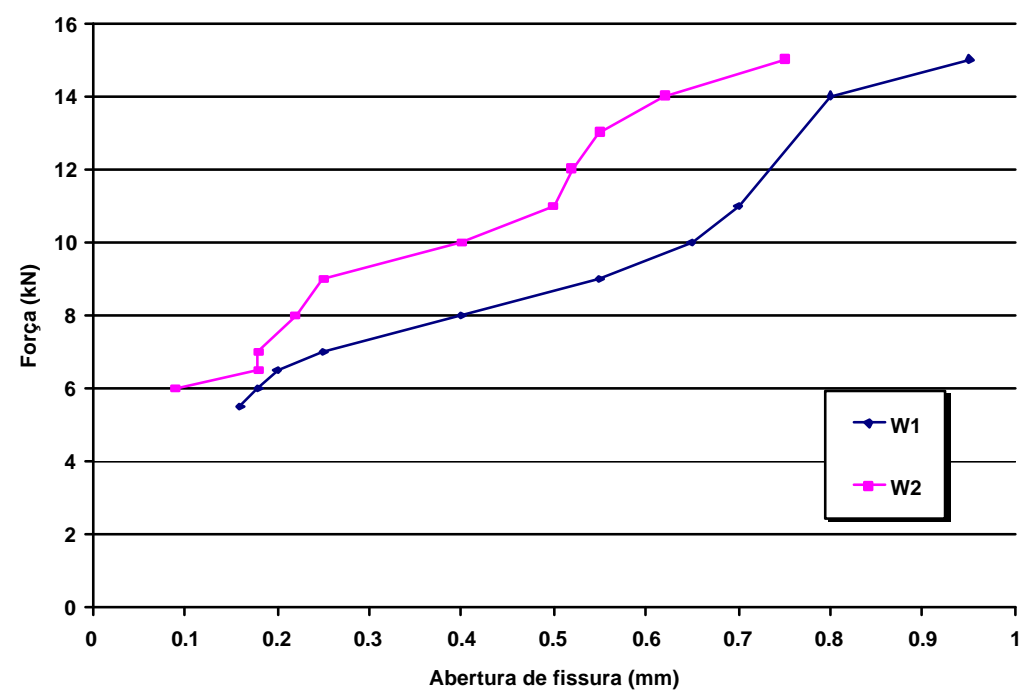

FIGURA 4.55 - Evolução da abertura de fissuras sobre o apoio central - modelo M40

De acordo com a definição de rótula plástica do CEB-90 (1991) e apresentado neste trabalho no item 3.5.1-b, o modelo M40 apresentou duas rótulas plásticas na região do apoio interno de comprimentos $\ell_{\mathrm{pl}}$ aproximadamente iguais a $19 \mathrm{~cm}$ cada uma delas, conforme pode ser analisado na figura 4.56 .

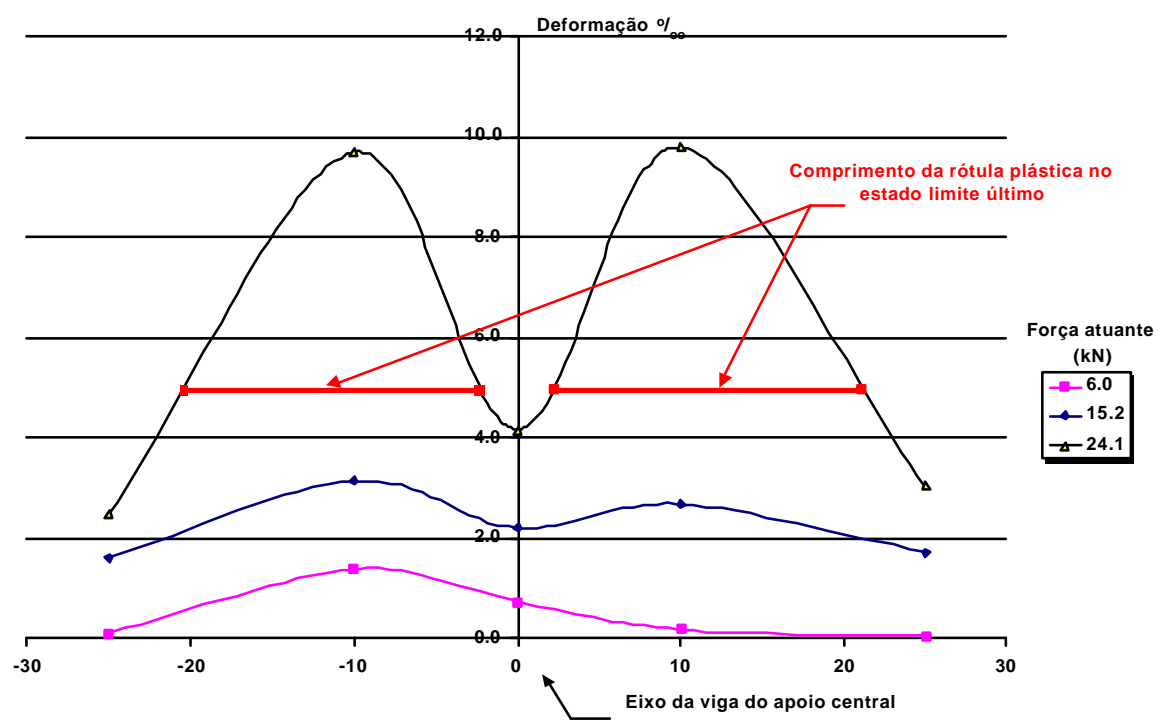

FIGURA 4.56 - Deformações na armadura negativa ao longo do seu eixo - M40 


\subsubsection{Ensaio do modelo Mac}

Na figura 4.57 vê-se que nas etapas de carga iniciais os momentos fletores crescem linearmente com as forças aplicadas. Quando é atingida a fissuração do modelo, ocorre uma queda brusca do momento fletor negativo, aumentando os valores dos momentos fletores positivos. Nas etapas de cargas seguintes os momentos fletores negativos começam a crescer novamente, não mais na mesma velocidade que os momentos fletores positivos. Nas etapas finais de carga é verificada uma forte redistribuição de esforços.

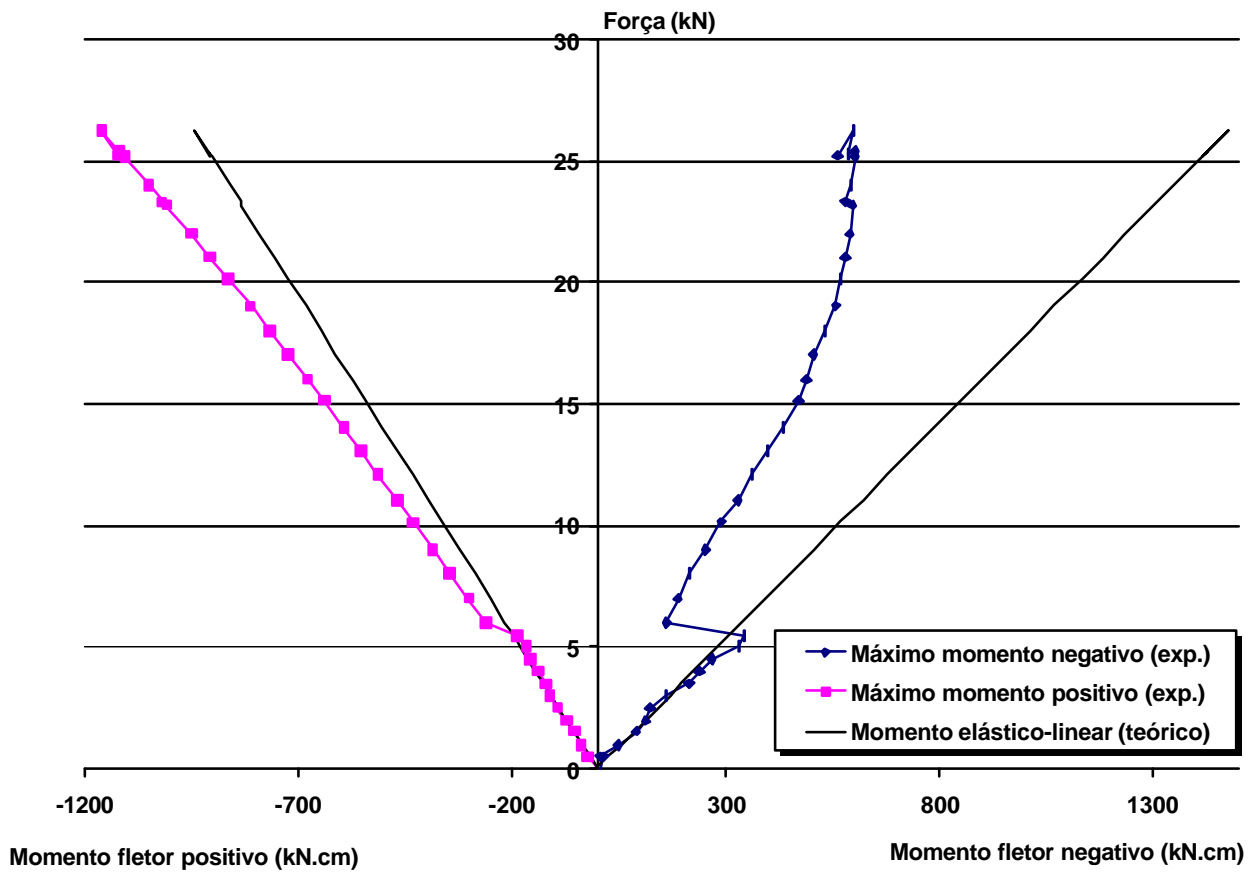

FIGURA 4.57 - Evolução dos máximos momentos fletores positivo e negativo - modelo Mac

$\mathrm{Na}$ figura 4.58 pode ser vista a evolução dos momentos fletores ao longo do eixo longitudinal do modelo. Pode ser verificado que, nas 4 últimas etapas de carga mostradas neste diagrama, o momento fletor negativo é praticamente constante (em torno de $500 \mathrm{kN} . \mathrm{cm}$ ), ao passo que o máximo momento fletor positivo tem um acréscimo de $70 \%$ em seus valores (de $680 \mathrm{kN} . \mathrm{cm}$ a $1160 \mathrm{kN} . \mathrm{cm}$ ).

O diagrama de força $x$ deslocamento para este modelo pode ser visto na figura 4.59. Como também ocorreu no modelo M40, quando foi atingida a força correspondente a fissuração do modelo, aconteceu uma descontinuidade neste diagrama. 


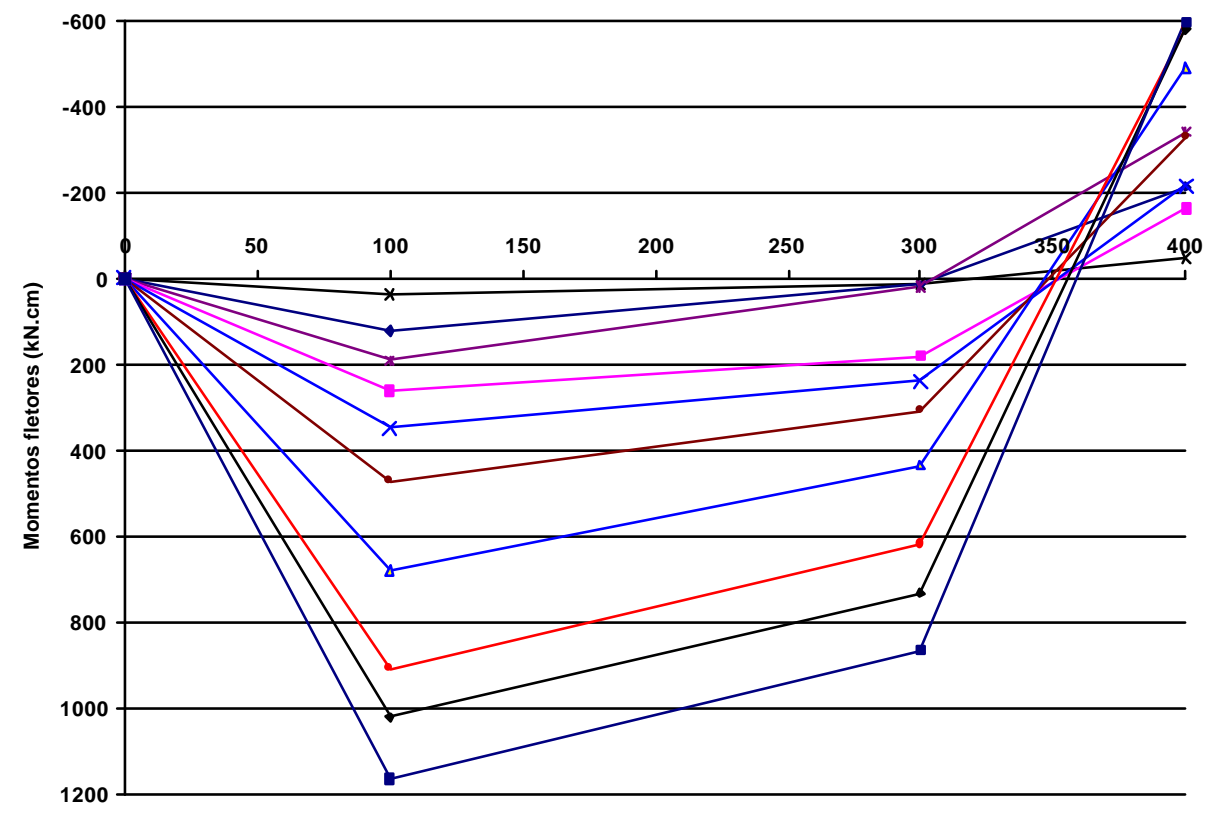

FIGURA 4.58 - Evolução dos momentos fletores - modelo Mac experimental

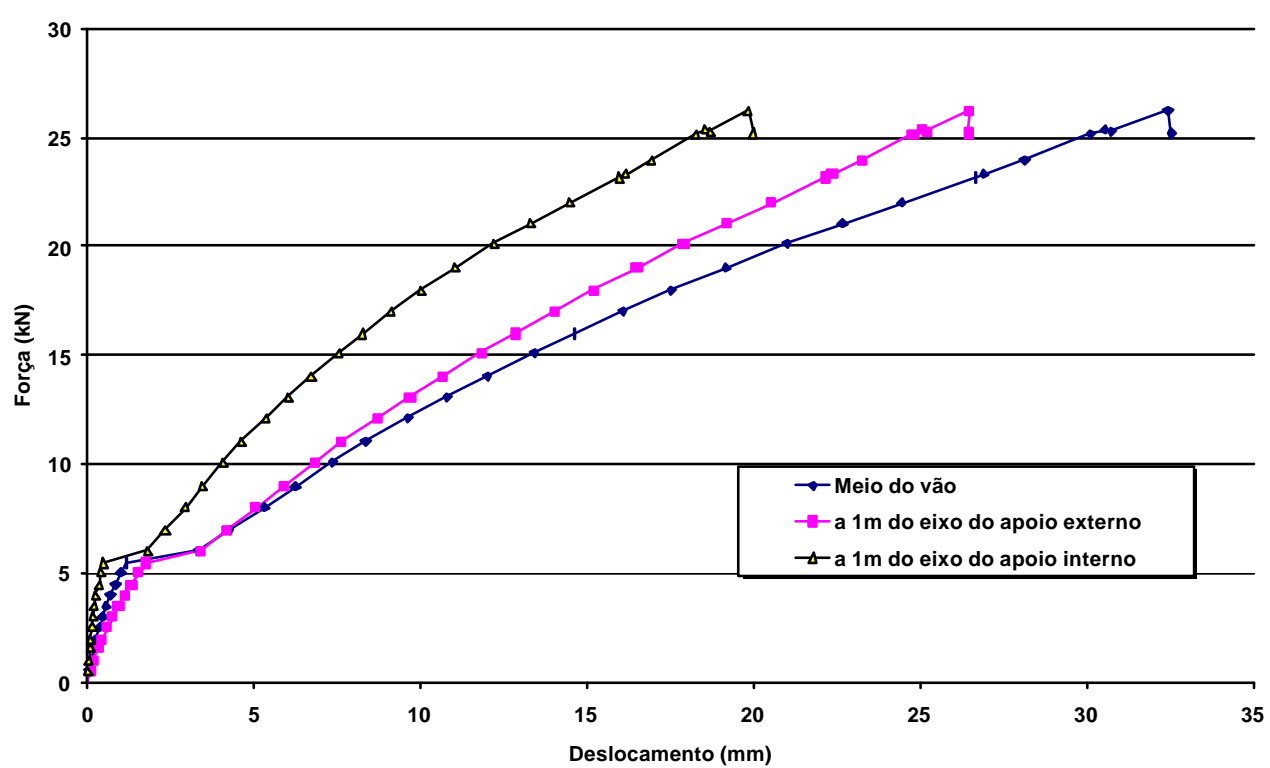

FIGURA 4.59 - Deslocamentos experimentais- modelo Mac

Na figura 4.60 é observada uma grande descontinuidade no diagrama de deformações da armadura construtiva do apoio interno para uma carga de $5,5 \mathrm{kN}$ decorrente da fissuração do apoio pela atuação do momento fletor negativo. Em seguida, são verificados acréscimos de deformações com a força atuante, mostrando uma participação efetiva da armadura construtiva na absorção de esforços. Neste 
mesmo diagrama é observado que o escoamento é atingido em vários pontos da armadura construtiva.

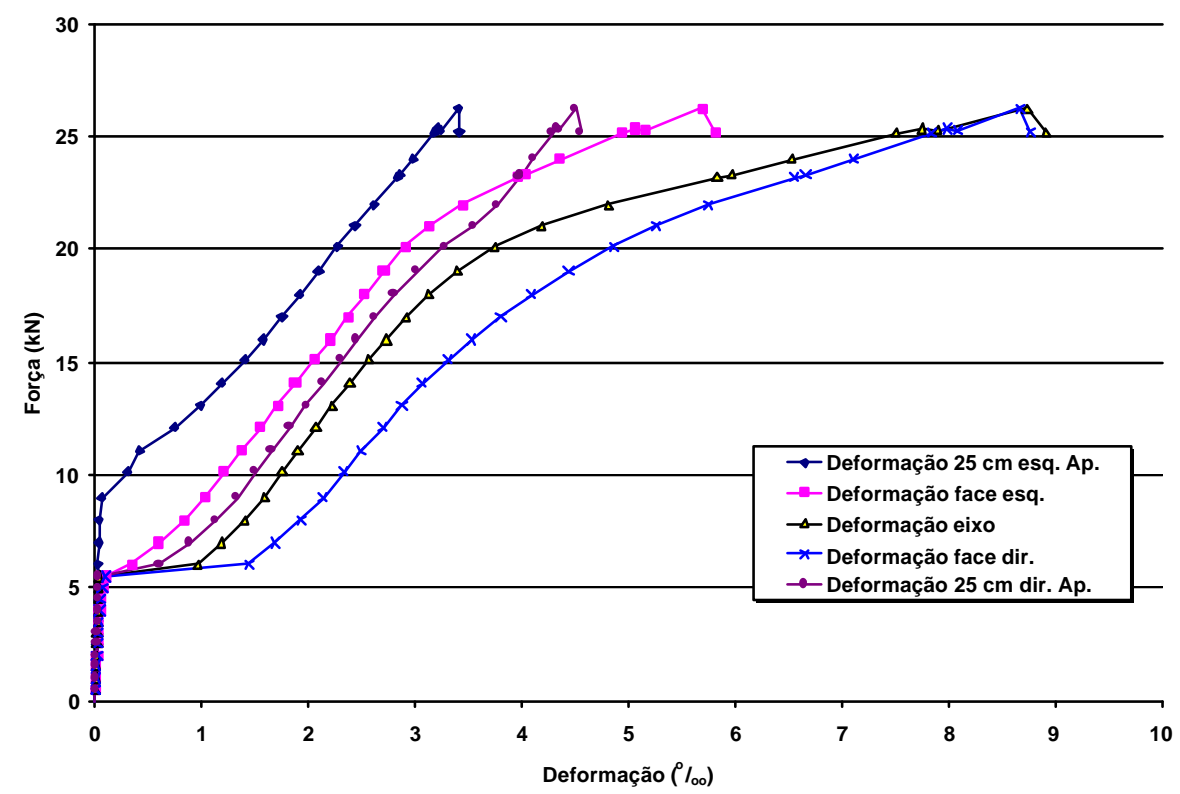

FIGURA 4.60 - Deformações experimentais na armadura negativa - modelo Mac

Na figura 4.61 está mostrado o diagrama força $x$ deformação no concreto.

Para a força de $5,5 \mathrm{kN}$ verifica-se uma queda acentuada nas deformações do concreto, queda esta provocada pela fissuração do concreto. Com novos acréscimos de carga as deformações no concreto voltam a crescer. Entretanto, para estados avançados de carga, as deformações no concreto começam a diminuir, evidenciando uma maior redistribuição dos momentos fletores negativos.

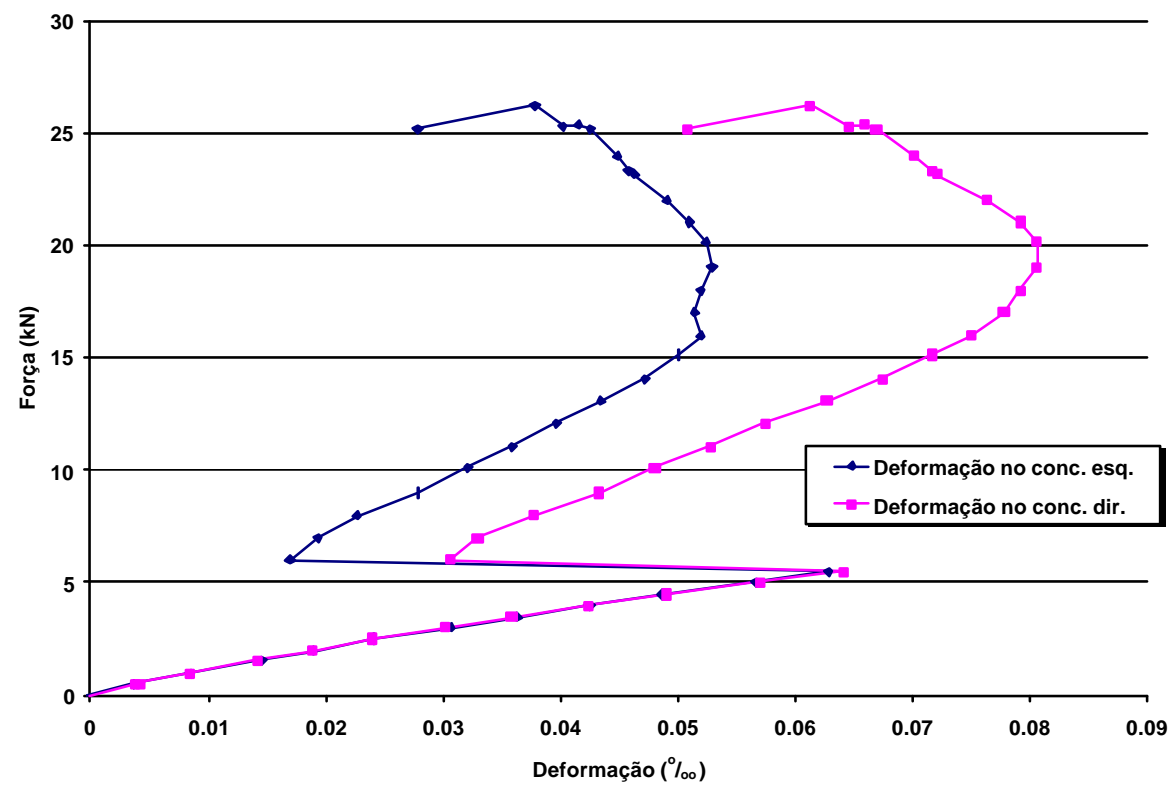

FIGURA 4.61 - Deformações experimentais no concreto - modelo Mac 
Esta faixa de laje apresentou apenas uma fissura principal por atuação dos momentos fletores negativos localizada junto a uma das faces da viga do apoio interno, onde esta fissura apresentou grande abertura, conforme verificado nas figuras 4.62 e 4.63 .

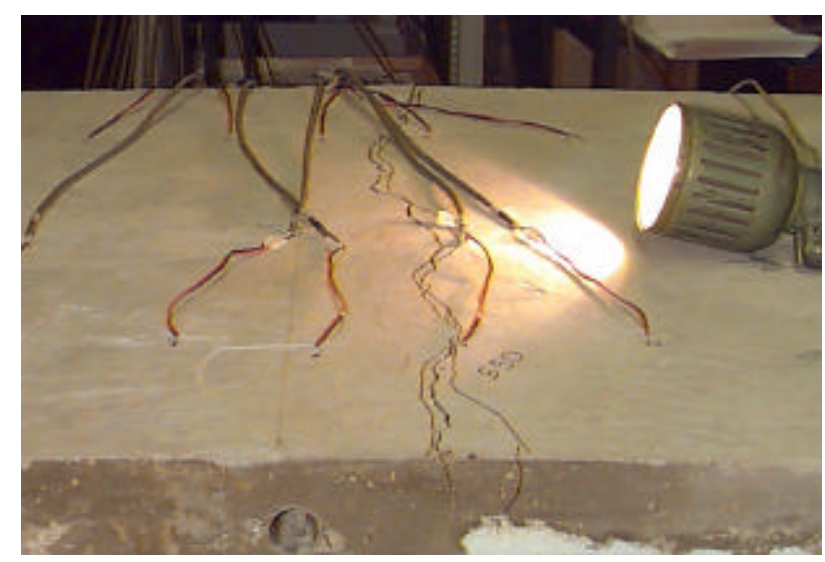

FIGURA 4.62 - Fissuração devido atuação do momento fletor negativo - modelo Mac

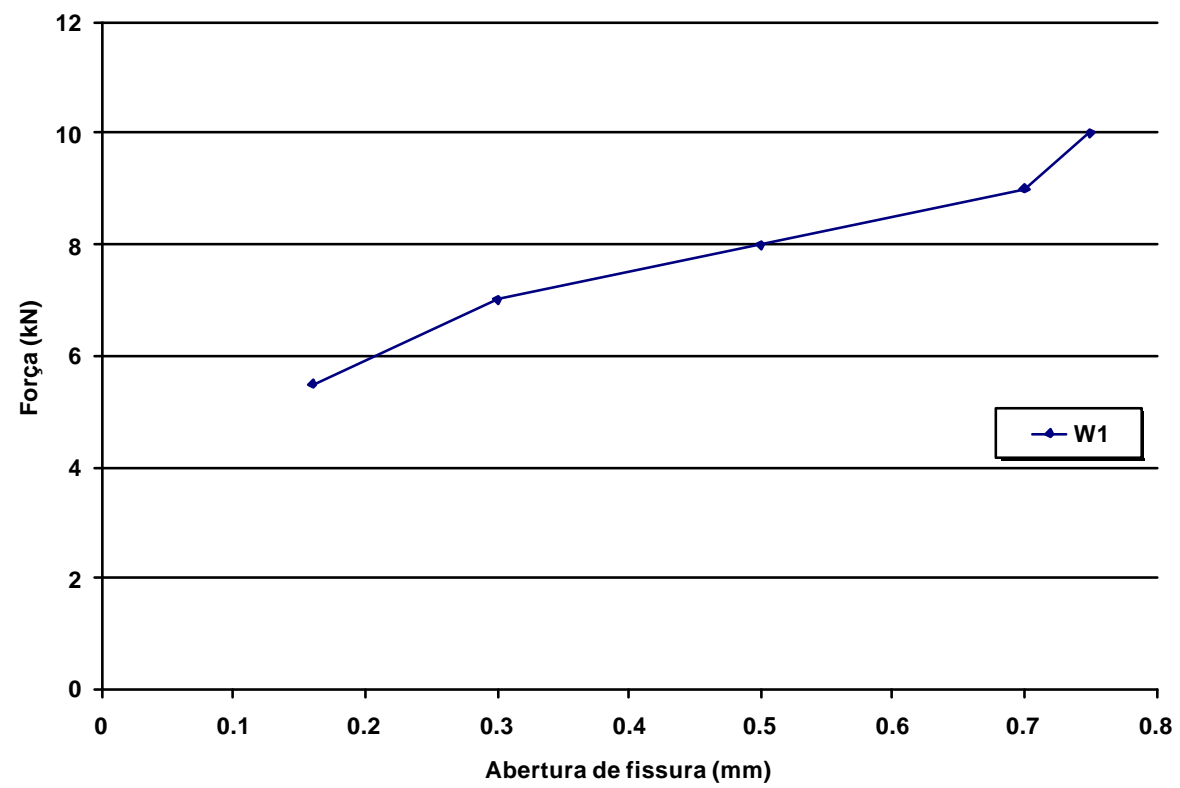

FIGURA 4.63 - Evolução da abertura de fissuras sobre o apoio central - modelo Mac

No estado último de carga, segundo a definição do CEB-90 (1991) o comprimento da rótula plástica do modelo Mac para o estado último de carga foi de aproximadamente $36 \mathrm{~cm}$, conforme mostra a figura 4.64 . 


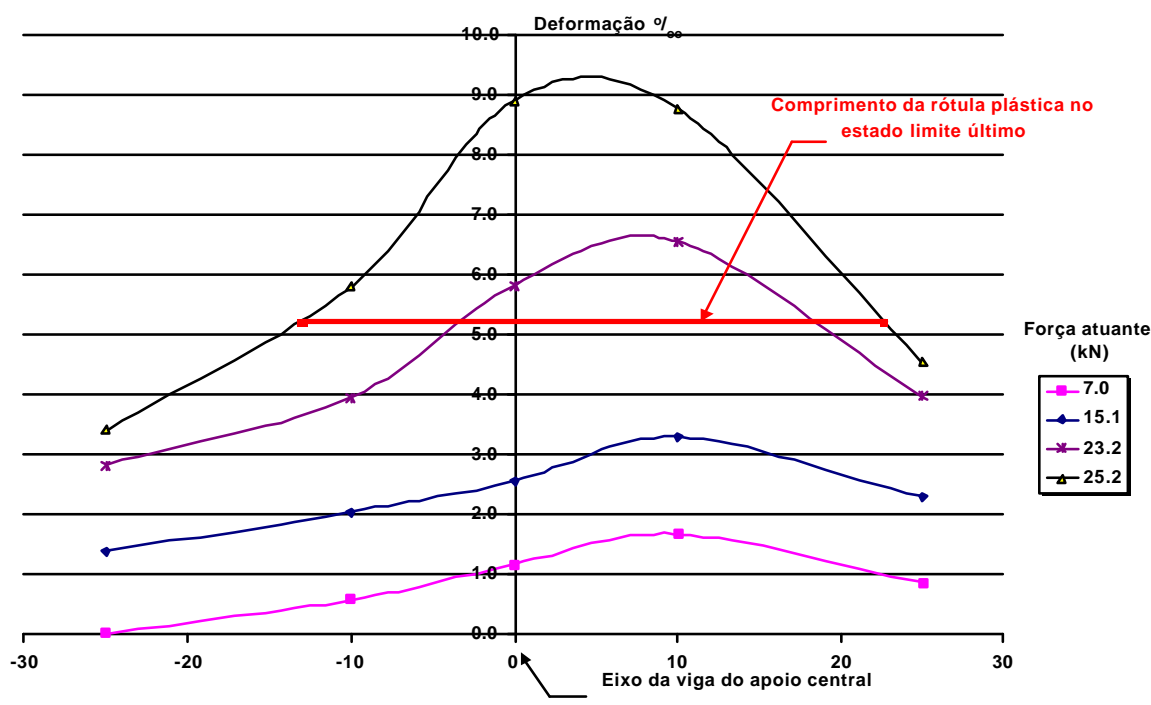

FIGURA 4.64 - Deformações na armadura negativa ao longo do seu eixo - Mac 


\subsection{Considerações iniciais}

Este capítulo trata das análises dos resultados experimentais e teóricos das faixas de lajes nervuradas descritas nos capítulos anteriores. Inicialmente são feitas comparações entre os resultados experimentais dos modelos M15, M40 e Mac. Em seguida são realizadas as simulações numéricas destes modelos a partir do modelo teórico proposto neste trabalho. Posteriormente, os parâmetros da relação momento $x$ curvatura e a capacidade de rotação das rótulas plásticas são ajustados e novas modelagens numéricas são feitas para as faixas de lajes nervuradas.

Este capítulo pode ser resumidamente apresentado da seguinte forma:

1. Comparações entre os resultados experimentais.

2. Idealizações das faixas de lajes para realização das modelagens numéricas.

3. Simulações numéricas dos modelos M15, M40 e Mac e comparações de resultados.

4. Ajustes nos parâmetros das modelagens numéricas e novas análises de resultados. 
5. Modelagem numérica do modelo dimensionado sem redistribuição dos momentos fletores negativos

\subsection{Comparações entre resultados experimentais}

Na tabela 5.1 são mostrados para cada modelo ensaiado os valores das máximas forças aplicadas pelos atuadores hidráulicos, os deslocamentos no meio do vão, os valores de máximos momentos fletores (positivo e negativo) e a relação entre os momentos fletores experimentais e aqueles calculados com análise elástico-linear com rigidez constante. Na figura 5.1 podem ser vistos os diagramas com a evolução dos máximos momentos fletores positivos e negativos.

TABELA 5.1 - Resultados experimentais

\begin{tabular}{|c|c|c|c|}
\hline Modelo & M15 & M40 & Mac \\
\hline $\begin{array}{c}\text { Força última de ensaio } \\
\text { (kN) }\end{array}$ & 26,0 & 26,0 & 26,2 \\
\hline $\begin{array}{c}\text { Deslocamento no meio do vão para } \\
\text { força de serviço - em torno de } \\
\text { 10kN(mm) }\end{array}$ & 9,2 & 9,2 & 7,3 \\
\hline $\begin{array}{c}\text { Deslocamento no meio do vão para } \\
\text { força de ensaio última (mm) }\end{array}$ & 35,5 & 39,3 & 32,5 \\
\hline $\begin{array}{c}\text { Momento fletor negativo experimental } \\
\text { para força última de ensaio (kN.cm) }\end{array}$ & 1533,7 & 1039,6 & 598,4 \\
\hline $\begin{array}{c}\text { Momento fletor negativo elástico- } \\
\text { linear para força última de ensaio } \\
\text { (kN.cm) }\end{array}$ & 1462,5 & 1462,5 & 1473,8 \\
\hline $\begin{array}{c}\text { Relação entre momentos fletores } \\
\text { negativo experimental e elástico-linear }\end{array}$ & 1,05 & 0,71 & 0,41 \\
\hline $\begin{array}{c}\text { Momento fletor positivo experimental } \\
\text { para força última de ensaio (kN.cm) }\end{array}$ & 916,2 & 1037,8 & 1162,0 \\
\hline $\begin{array}{c}\text { Momento fletor positivo elástico- } \\
\text { linear para força última de ensaio } \\
\text { (kN.cm) }\end{array}$ & 934,4 & 934,4 & 941,6 \\
\hline $\begin{array}{c}\text { Relação entre momentos fletores } \\
\text { positivo experimental e elástico-linear }\end{array}$ & 0,98 & 1,11 & 1,23 \\
\hline
\end{tabular}


Pode-se constatar que as forças últimas em todos os modelos apresentaram valores próximos a 26kN. Esta força só foi atingida nos modelos Mac e M40 porque eles apresentaram uma grande capacidade de rotação das rótulas plásticas na região do apoio central. Para o modelo Mac a rótula plástica foi formada para uma força próxima de $15 \mathrm{kN}$ e no modelo M40, a rótula plástica surgiu para uma força próxima de $20 \mathrm{kN}$. Os graus de redistribuição $(\eta)$ encontrados nos modelos Mac e M40 foram, respectivamente de 59\% e $29 \%$.

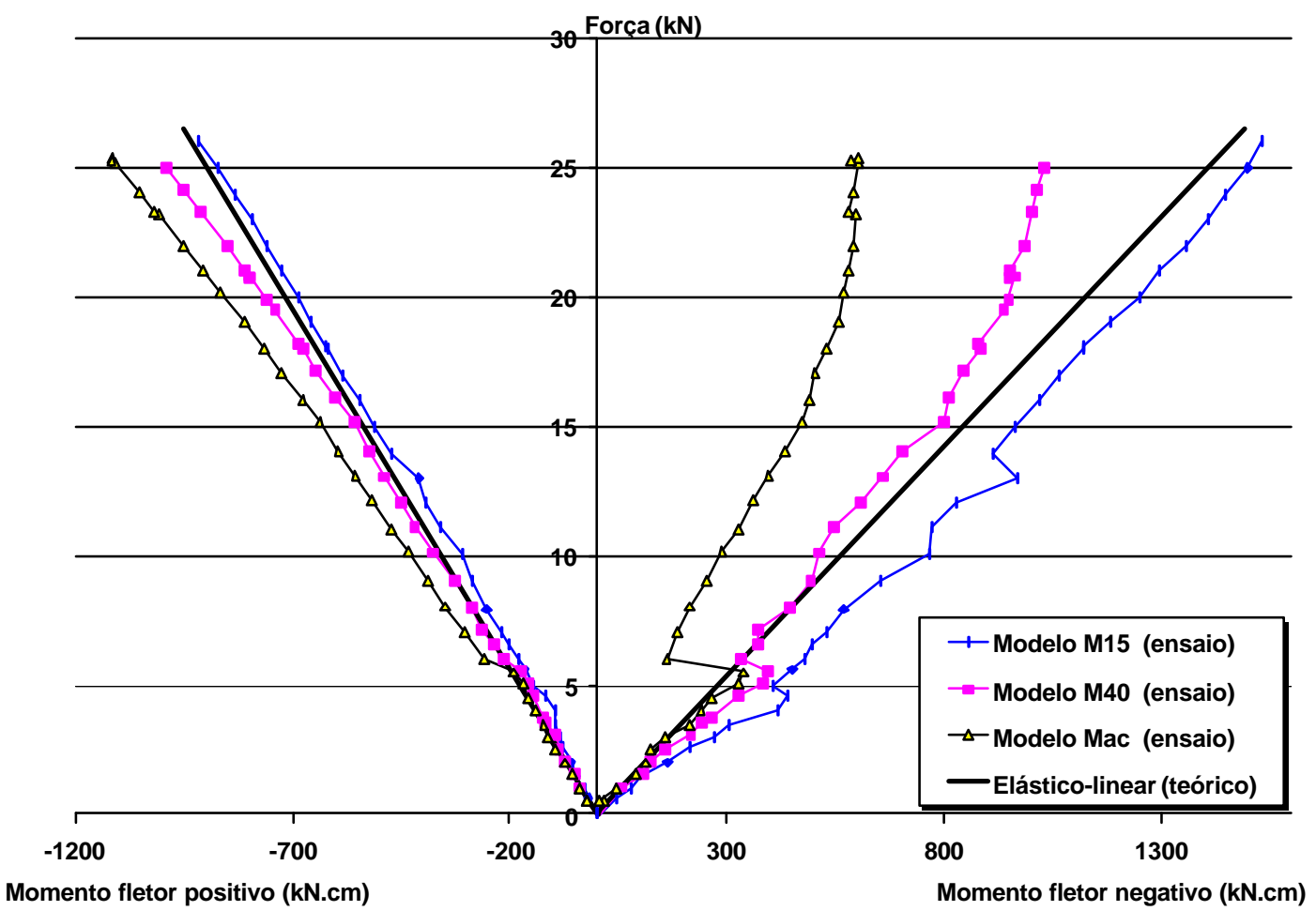

FIGURA 5.1 - Evolução dos momentos fletores experimentais nos modelos M15, M40 e $\mathrm{Mac}$

É observado que mesmo o modelo M40 tendo apresentado redistribuição de esforços ao longo das etapas de carga, o grau de redistribuição encontrado na última etapa de carga no ensaio (29\%) foi inferior ao grau de redistribuição idealizado no dimensionamento (40\%).

Quanto ao modelo M15, observou-se que ele não apresentou redistribuição dos momentos fletores negativos em nenhum momento do ensaio. Ao contrário do que ocorreu aos modelos M40 e Mac, o modelo M15 apresentou na última etapa de carga de 
ensaio momentos fletores negativos experimentais aproximadamente 5\% maiores àqueles obtidos na análise elástico-linear com rigidez constante.

De acordo com os diagramas força $x$ deformação no concreto comprimido apresentados nas figuras 4.46, 4.53 e 4.61 , vê-se que todos os modelos que foram ensaiados apresentaram deformações do concreto junto ao apoio central bem inferiores a 3,5\% , demonstrando que, se os atuadores hidráulicos continuassem aplicando força, a ruína dificilmente ocorreria por esmagamento do concreto comprimido, mas por ruptura da armadura tracionada conforme sugerem as figuras 4.45, 4.52 e 4.60 .

Pela definição de rótula plástica do CEB-90 (1991), os três modelos ensaiados apresentaram rotações elásticas $\left(\theta_{\mathrm{el}}\right)$ até o instante em que a armadura sobre o apoio central iniciou o escoamento e nas etapas seguintes de carga os modelos apresentaram rotações plásticas $\left(\theta_{\mathrm{pl}}\right)$.

As rótulas plásticas geradas nos modelos Mac e M40 concentram as deformações plásticas em poucas fissuras, ao passo que no modelo M15 apresenta uma fissuração mais distribuída porém com fissuras menos abertas na região de sua rótula plástica. Esta mudança na configuração da fissuração das rótulas plásticas próximas ao apoio central basicamente é influenciada pela taxa de armadura negativa, conforme já discutido no item 3.4 deste trabalho.

Pela configuração das fissuras que surgiram nos modelos durante os ensaios, percebe-se que as rótulas plásticas apresentadas por estes modelos são decorrentes de fissuras oriundas do esforço de flexão e como já havia sido comentado, será dispensada nas modelagens numéricas, utilizando o modelo de Darmstandt-Leipzig, a parcela das rotações plásticas decorrentes do esforço de cisalhamento.

Ainda com relação aos modelos M40 e Mac, teoricamente se obteriam fissuras menos abertas se fossem utilizadas barras de aço com nervuras. Entretanto, esta solução poderia provocar uma redução na capacidade de rotação das rótulas plásticas, não sendo, portanto, a melhor situação. Neste caso, seria aconselhável utilizar barras de aço com diâmetros e espaçamentos menores, caso seja possível adotar esta solução. 
O estudo do modelo M15 sugere que, mesmo o dimensionamento sendo realizado a partir de um cálculo plástico com determinada redistribuição de esforços, na estrutura real esta redistribuição pode não ser verificada.

Ainda na figura 5.1 percebe-se que no início da fissuração dos modelos a curva de momentos fletores negativos está mais próxima de uma reta quanto maior é a taxa de armadura negativa. Consequientemente, se a faixa de laje nervurada contínua fosse dimensionada a partir da análise elástico-linear com rigidez constante sem redistribuição de esforços (chamado a partir deste ponto do texto de modelo M0), na análise não-linear desta estrutura não seria encontrada redistribuição dos momentos fletores negativos e estes momentos fletores apresentariam valores maiores àqueles obtidos com modelo elástico linear com inércia constante.

Porém, se a força dos atuadores hidráulicos continuasse aumentando, acredita-se que também ocorreria redistribuição dos momentos fletores negativos para os modelos M0 e M15, pois estes passariam a apresentar comportamento de membrana. Na figura 5.2 é observada uma das faixas de laje nas últimas etapas de carga de ensaio, quando já começava a desenvolver comportamento de membrana. Esta análise não foi abordada neste trabalho, pois ao atingir esta situação, a estrutura se apresenta demasiadamente deformada. Além disso, surgem forças horizontais nos apoios das lajes as quais a estrutura não é capaz de absorver, uma vez que não foi previsto em dimensionamento.

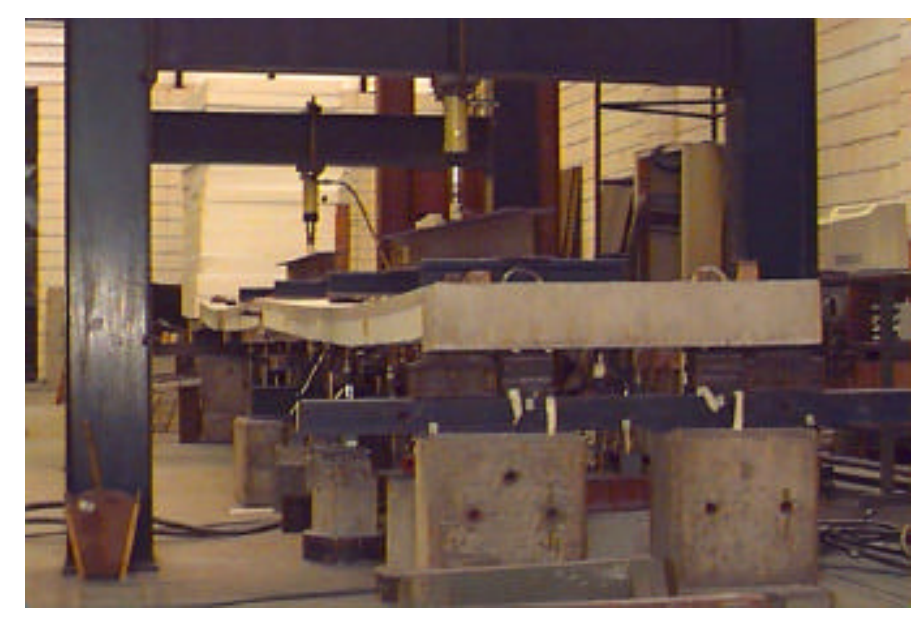

FIGURA 5.2 - Ensaio da faixa de laje nas etapas finais de carga 
De acordo com a forma na qual o dimensionamento foi realizado, o modelo M0 apresentaria a linha neutra teórica para estado limite último próxima ao limite entre os domínios 3 e 4 . Como é inferido que este modelo não apresenta redistribuição de esforços para a situação de ensaio, percebe-se que a redistribuição usualmente adotada por projetistas no cálculo plástico (considerando o valor do momento fletor negativo igual ao momento resistente da seção conforme apresentado no item 2.4.3 deste trabalho) não garante que o modelo apresente esforços redistribuídos no estado limite último.

Os deslocamentos no meio do vão para os modelos M15 e M40 (figura 5.3) são coincidentes para as forças de serviço (em torno de $10 \mathrm{kN}$ ). A curva de deslocamentos do modelo Mac apresenta o mesmo comportamento à curva de deslocamentos dos outros dois modelos e, para um mesmo nível de solicitação, deslocamentos menores aos deslocamentos dos modelos M15 e M40. Com isto, dois fatos sobressaem:

1. Embora o modelo Mac tenha sido dimensionado como uma laje simplesmente apoiada, a verificação dos deslocamentos pode ser realizada considerando-se a continuidade estrutural garantida pela armadura construtiva disposta junto ao apoio central. Ressalta-se que esta conclusão é válida para as condições de armaduras existentes no ensaio, ou seja, garantir que as armaduras estão bem ancoradas nos vão adjacentes e dispostas próximas a borda superior da capa de concreto. 


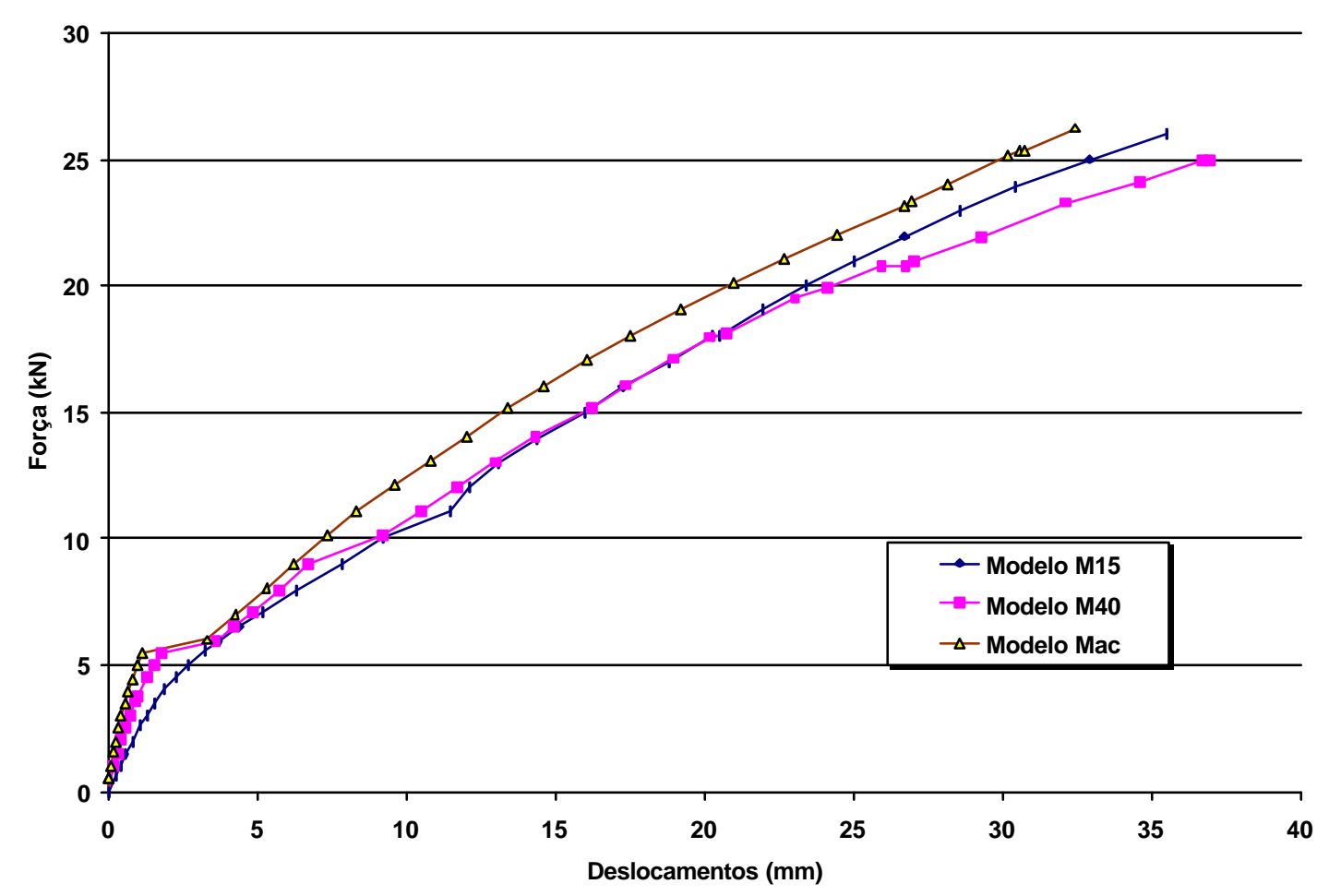

FIGURA 5.3 - Deslocamentos experimentais no meio do vão

2. O deslocamento no meio do vão do modelo Mac foi menor que os deslocamentos dos modelos M40 e M15 porque, por problemas na elaboração das fôrmas, o modelo Mac apresentou uma capa de concreto com aproximadamente $1 \mathrm{~cm}$ mais espessa que as capas de concreto dos modelos M15 e M40 (discutido no item 4.3.1 deste trabalho). Com isto, o modelo Mac apresentou uma inércia maior, cujo efeito foi refletido diretamente nos deslocamentos.

\subsection{Idealizações feitas na modelagem numérica das faixas de lajes}

As simulações numéricas das faixas de lajes foram realizadas tomando-se partido da simetria em relação ao apoio central. Portanto, as faixas de lajes nervuradas foram discretizadas em 40 elementos e 41 nós conforme mostrado na figura 5.4. 


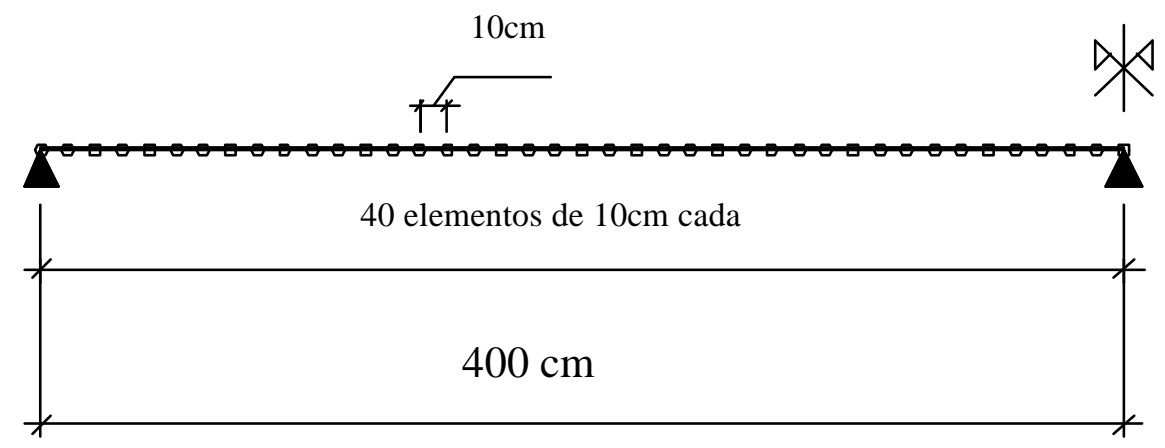

FIGURA 5.4 - Discretização das faixas de lajes

Na figura 5.5 está mostrado o esquema das forças concentradas utilizadas nas modelagens numéricas.

$\mathrm{Na}$ confecção dos diagramas teóricos foram descontados as parcelas de forças, momentos fletores e deslocamentos decorrentes da atuação do peso próprio da laje e dos equipamentos que ficaram sobre ela durante a realização dos ensaios.

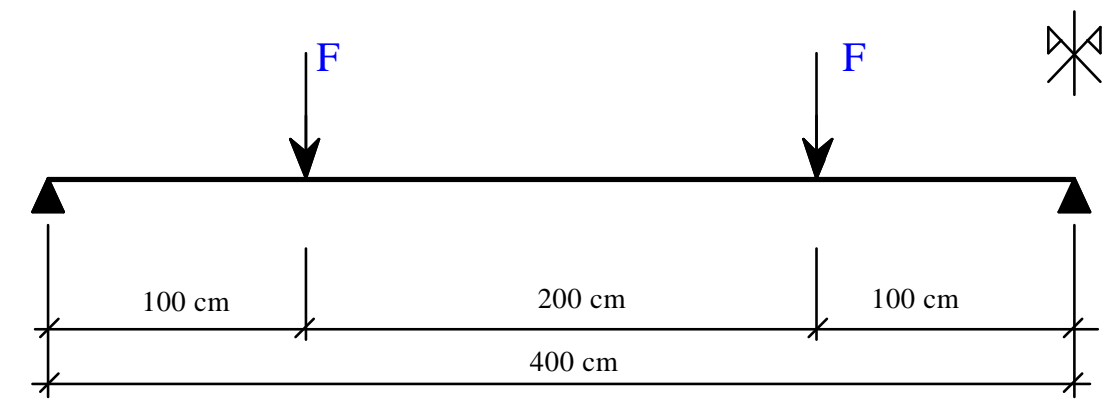

FIGURA 5.5 - Esquema de forças concentradas utilizadas nas modelagens numéricas

Foram considerados, nas simulações numéricas, barras lisas $\left(\beta_{1}=0,5\right)$ e primeiro carregamento atuando na estrutura $\left(\beta_{2}=0,8\right)$, conduzindo ao valor do parâmetro $\beta_{\mathrm{b}}$ do CEB-90 (1991) igual 0,4.

O momento fletor limite entre os estádios I e II foi determinado para 0,89 do valor do momento de fissuração $\left(\sqrt{0,8} \cdot \mathrm{M}_{\mathrm{r}}\right)$ e não o valor de 0,63 do momento de fissuração $\left(\sqrt{0,4} \cdot M_{r}\right)$ conforme se obteria com a formulação do CEB-90 (1991), quando se utilizam barras lisas. Esta consideração se justifica na realização dos diagramas que comparam os resultados entre o modelo teórico e o modelo experimental. 
Como a fábrica que doou as vigotas pré-moldadas não forneceu amostras para ensaios dos aços da armação treliçada e armaduras adicionais, consideraram-se como propriedades mecânicas destes aços, nas simulações numéricas, as mesmas propriedades das barras ensaiadas com diâmetro de 4,2 $\mathrm{mm}$ utilizadas como armadura negativa.

Para se realizar as análises não-lineares a partir das relações momento $x$ curvatura em conjunto com a técnica do carregamento incremental, inicialmente é necessário calcular as características mecânicas e geométricas dos modelos analisados. As seções de referência em que estas propriedades foram calculadas estão mostradas na figura 5.6.

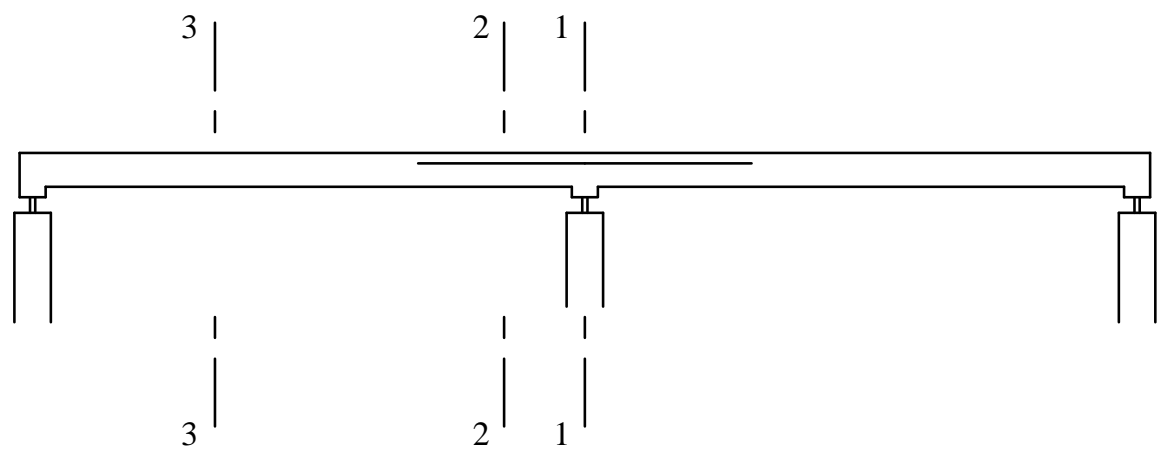

FIGURA 5.6 - Seções de referência em que foram calculadas as características mecânicas e geométricas dos modelos teóricos

As características mecânicas e geométricas das seções de referência dos modelos serão apresentadas em forma de tabelas na ocasião em que forem apresentadas as modelagens numéricas dos respectivos modelos.

Junto ao apoio central do modelo numérico foi colocado um elemento mais rígido de modo a reproduzir o alargamento na altura do apoio. Isto possibilita o aparecimento de rótulas plásticas teóricas no eixo ou na face do apoio (a $10 \mathrm{~cm}$ do eixo), conforme discutido no item 3.5.1 deste trabalho.

Esta possibilidade do surgimento de uma rótula plástica teórica no eixo ou na face do apoio se torna importante na modelagem numérica porque, sendo o diagrama dos momentos fletores muito inclinado na região dos apoios internos, qualquer variação na posição da rótula será determinante na etapa de carga em que a rótula plástica será criada. 
Novamente é relembrado aqui que as rótulas plásticas estão limitadas a uma única seção somente no modelo teórico, uma vez que, conforme apresentado nas análises teóricas do capítulo 3, na estrutura real a rótula plástica corresponde a um trecho de comprimento $\ell_{\mathrm{pl}}$ do elemento estrutural.

\subsection{Comparação entre resultados teóricos e experimentais}

\subsubsection{Modelagem numérica do modelo M15}

Em função da geometria da seção transversal, da área de aço e das propriedades dos materiais, foram calculados os parâmetros necessários para a utilização da relação momento $x$ curvatura do modelo M15 (tabela 5.2). A partir da modelagem numérica no ANSYS ${ }^{\circledR}$ utilizando os dados desta tabela, foram construídos os diagramas força $x$ momentos fletores e força $x$ deslocamentos teóricos, sendo estes comparados com os valores obtidos em ensaio.

No diagrama força $x$ momentos fletores (figura 5.7), a força em que se deu a fissuração no modelo teórico foi de $2 \mathrm{kN}$, ao passo que no ensaio a fissuração se deu para uma força de aproximadamente de 4,5kN. Nas etapas de carga posteriores, os valores dos diagramas de momento fletores teórico não-linear e experimental se aproximam. Notar que os momentos fletores negativos teóricos não-lineares e experimentais são maiores que os momentos fletores negativos obtidos a partir da análise elástico-linear com rigidez constante. Este fenômeno ocorre em todas as etapas de carga, caracterizando a não redistribuição dos momentos fletores negativos. Para o valor de força última $(26 \mathrm{kN})$, os momentos fletores negativos experimental e teórico não-linear foram, respectivamente, 1,05 e 1,09 maiores que o momento fletor negativo obtido a partir da análise elásticolinear com rigidez constante.

TABELA 5.2 - Características geométricas e mecânicas das seções de referência- modelo 


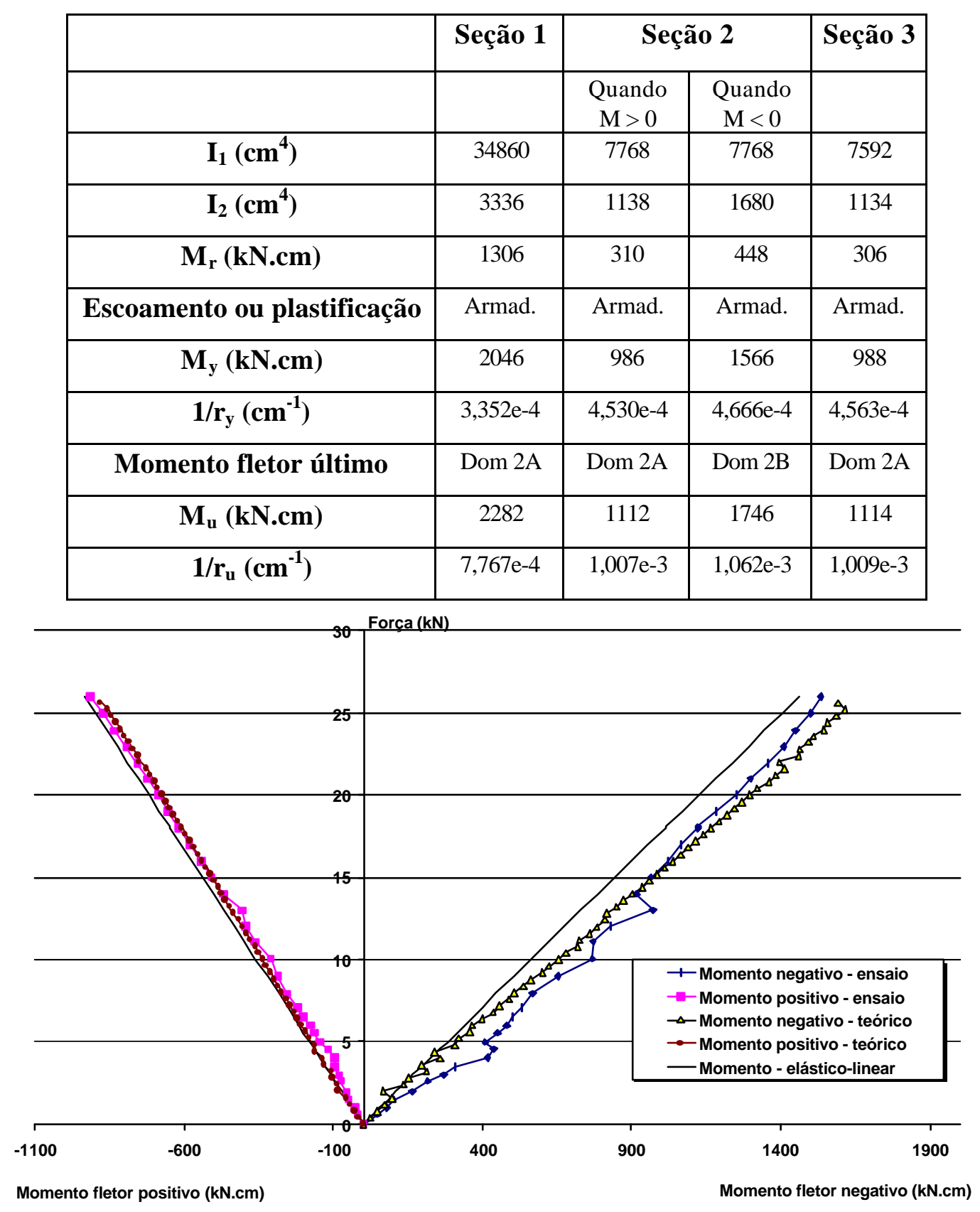

FIGURA 5.7 - Máximos momentos fletores - modelo M15

Com relação ao diagrama força $x$ deslocamento (figura 5.8), verificam-se que os deslocamentos teóricos começaram a crescer mais rapidamente que os deslocamentos obtidos no ensaio para uma mesma etapa de carga. Nas etapas seguintes de carga, as curvas dos deslocamentos teóricas e experimentais para as seções do meio do vão e a $1 \mathrm{~m}$ do eixo do apoio externo crescem paralelas às respectivas curvas experimentais. A possível causa da translação entre as curvas de deslocamentos teórico e experimental decorre do baixo valor do momento de fissuração utilizado nas modelagens numéricas. 


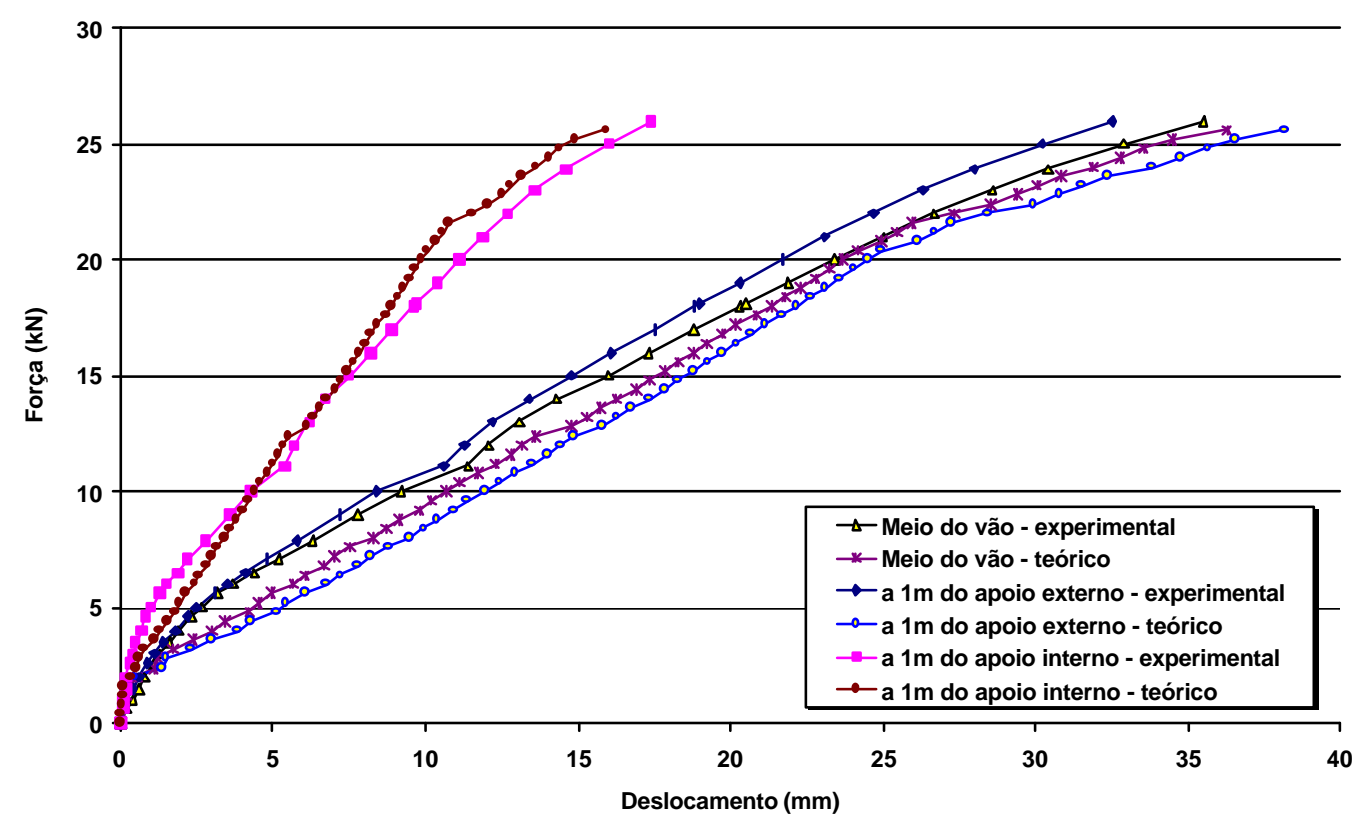

FIGURA 5.8 -Deslocamentos teóricos e experimentais - modelo M15

\subsubsection{Modelagem numérica do modelo M40}

Os parâmetros necessários para a realização da análise não-linear do modelo M40 utilizando a relação momento $x$ curvatura estão dispostos na tabela 5.3. Os diagramas de força $x$ momentos fletores e força $x$ deslocamentos deste modelo estão mostrados nas figuras 5.9 e 5.10 , respectivamente.

No diagrama da figura 5.9, a força teórica para o início da fissuração foi de $2 \mathrm{kN}$, ao passo que no ensaio a fissuração iniciou para uma força de $5,5 \mathrm{kN}$. O valor da força que provoca fissuração no ensaio do modelo M40 pode ser facilmente observada nos diagrama força $x$ deformação na armadura tracionada e no concreto comprimido das figuras 4.52 e 4.53 do capítulo 4. Nas etapas posteriores de carga os valores de momentos fletores teóricos não-lineares e experimentais tendem a se igualarem. Diferentemente do modelo M15, quando ocorre a fissuração, os momentos fletores negativos não-lineares se tornam menores que os momentos fletores negativos obtidos a partir da análise elástico-linear com rigidez constante. Notar a boa aproximação dos 
momentos fletores teóricos com os momentos fletores experimentais para estados avançados de carga.

TABELA 5.3 - Características geométricas e mecânicas das seções de referência- modelo M40

\begin{tabular}{|c|c|c|c|c|}
\hline & Seção 1 & \multicolumn{2}{|c|}{ Seção 2} & Seção 3 \\
\hline & & $\begin{array}{c}\text { Quando } \\
M>0\end{array}$ & $\begin{array}{c}\text { Quando } \\
\mathrm{M}<0\end{array}$ & \\
\hline$I_{1}\left(\mathrm{~cm}^{4}\right)$ & 34580 & 7572 & 7572 & 7734 \\
\hline$I_{2}\left(\mathrm{~cm}^{4}\right)$ & 1091 & 1058 & 1016 & 1442 \\
\hline$M_{r}(k N . c m)$ & 1292 & 304 & 432 & 314 \\
\hline Escoamento ou plastificação & Armad. & Armad. & Armad. & Armad. \\
\hline $\mathrm{M}_{\mathrm{y}}(\mathbf{k N} . \mathrm{cm})$ & 1294 & 1102 & 972 & 1280 \\
\hline $1 / r_{y}\left(\mathrm{~cm}^{-1}\right)$ & $3,233 \mathrm{e}-4$ & $5,476 \mathrm{e}-4$ & $4,762 \mathrm{e}-4$ & $4,665 \mathrm{e}-4$ \\
\hline Momento fletor último & Dom. 2A & Dom. 2B & Dom. 2B & Dom. 2A \\
\hline$M_{u}(k N . c m)$ & 1440 & 1250 & 1132 & 1444 \\
\hline $1 / r_{u}\left(\mathrm{~cm}^{-1}\right)$ & $7,561 \mathrm{e}-4$ & $1,211 \mathrm{e}-3$ & $1,118 \mathrm{e}-3$ & $1,027 \mathrm{e}-3$ \\
\hline
\end{tabular}

Para uma força em torno de $19 \mathrm{kN}$, é criada no modelo teórico uma rótula plástica teórica na seção a $10 \mathrm{~cm}$ do eixo do apoio central, conforme simplificações apresentada no item 3.5.1 deste trabalho. Nas etapas seguintes de carga o momento fletor negativo não-linear teórico na rótula plástica mantém-se constante, ao passo que os valores dos momentos fletores positivos não-lineares teóricos vão crescendo, evidenciando a redistribuição dos esforços no modelo teórico.

A força última encontrada no ensaio $(26 \mathrm{kN})$ foi ligeiramente maior que a força última obtida considerando o modelo teórico não-linear $(23,6 \mathrm{kN})$. Os valores dos momentos fletores últimos positivos e negativos experimentais foram aproximadamente $10 \%$ maiores àqueles encontrados no modelo teórico. 


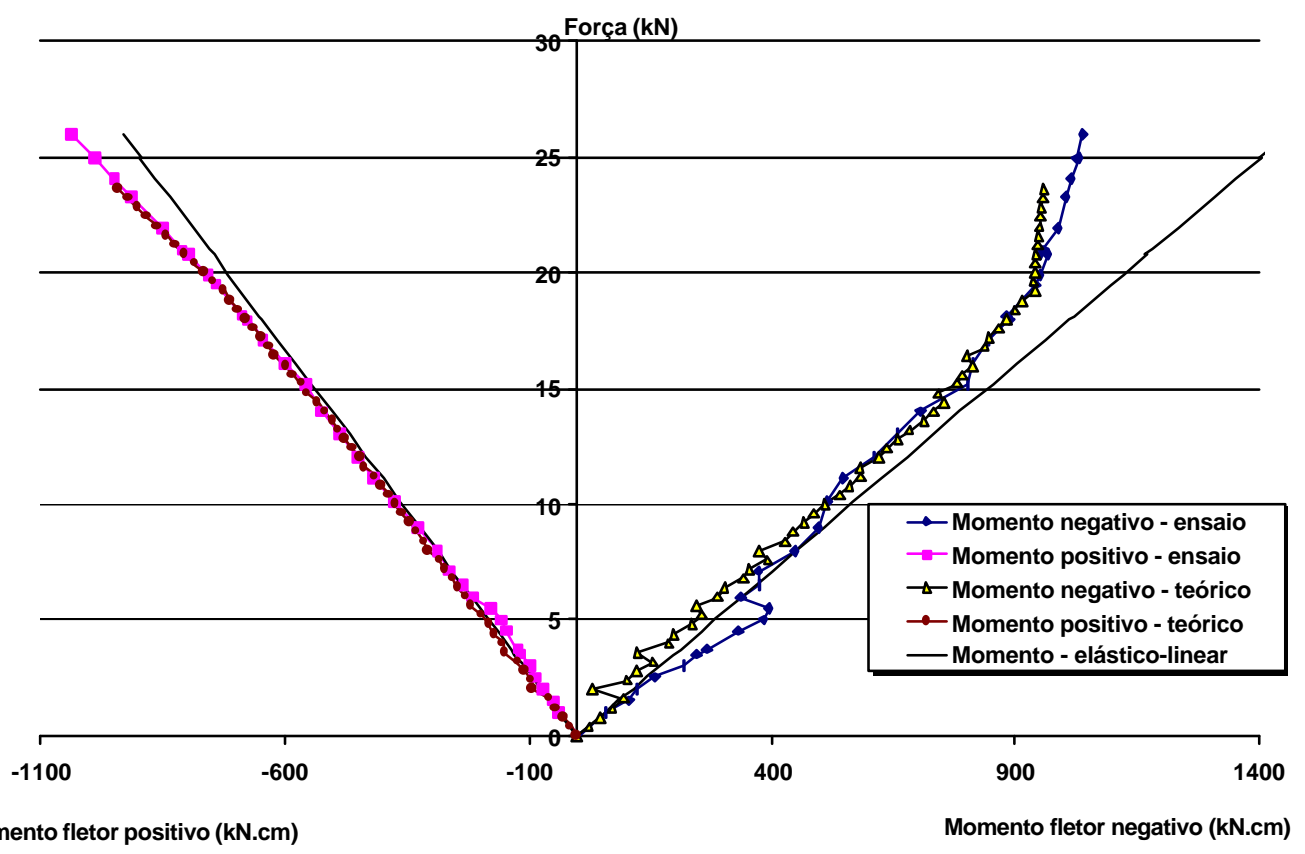

Momento fletor positivo (kN.cm)

Momento fletor negativo (kN.cm)

FIGURA 5.9 - Máximos momentos fletores - modelo M40

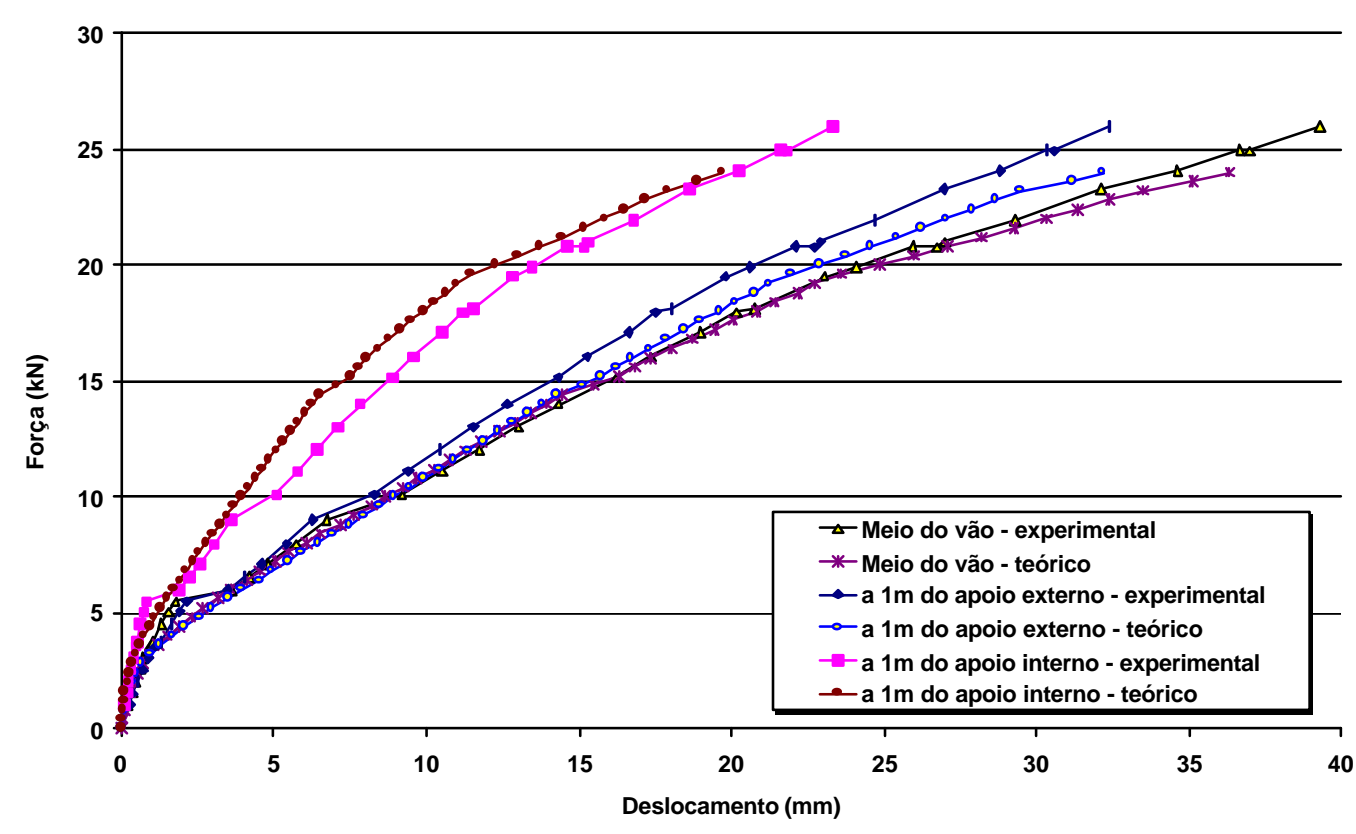

FIGURA 5.10 -Deslocamentos teóricos e experimentais - modelo M40

O último incremento de carga na simulação numérica do modelo M40 ocorreu quando foi atingida a capacidade de rotação da rótula plástica teórica criada junto ao apoio central. Como a carga última de ensaio foi aproximadamente $10 \%$ maior que a força última teórica, pode-se concluir que o modelo real apresenta uma capacidade de rotação 
plástica ligeiramente superior ao critério limitante da curvatura última da seção, medida a partir de aproximações geométricas de deslocamentos, conforme apresentado em 3.5.1-a.

No estado limite último, os graus de redistribuições de momentos fletores encontrados no modelo teórico não-linear e experimental foram, respectivamente, $27 \%$ e $29 \%$, valores ainda distantes daquele idealizado no dimensionamento do modelo M40, onde foi considerada uma redistribuição de $40 \%$ dos momentos fletores negativos.

Assim como ocorreu no modelo M15, os deslocamentos do modelo teórico não-linear começaram a crescer mais rápido que os deslocamentos experimentais. Mais uma vez, possivelmente isto decorre do baixo valor do momento de fissuração utilizado nas modelagens numéricas. Ainda assim, no diagrama força $x$ deslocamentos pode ser observado que o deslocamento teórico no meio do vão está bem próximo do valor do deslocamento experimental naquela seção.

\subsubsection{Modelagem numérica do modelo Mac}

As características mecânicas e geométricas das seções de referência do modelo Mac estão apresentadas na tabela 5.4. Nas figuras 5.11 e 5.12 estão representados, respectivamente, os diagramas força $x$ momentos fletores e força $x$ deslocamentos para este modelo.

No diagrama força $x$ momentos fletores, fica bem claro a etapa de carga em que ocorre a fissuração do modelo Mac. No modelo teórico não-linear, a força em que iniciou a fissuração foi de $3,2 \mathrm{kN}$, ao passo que no ensaio o início da fissuração ocorreu para uma força de 5,5kN. No instante em que a carga de fissuração nos modelos teórico não-linear e experimental é atingida, ocorre uma queda nos valores dos momentos fletores negativos, com o conseqüente aumento dos momentos fletores positivos. Nas etapas seguintes de carga, os momentos fletores negativos teóricos não-lineares e experimentais voltam a crescer, mas não na mesma taxa de crescimento que possuía antes de iniciar a fissuração. Nas etapas finais de carga, encontra-se uma grande capacidade de redistribuição dos momentos fletores. 
TABELA 5.4 - Características geométricas e mecânicas das seções de referência - modelo $\mathrm{Mac}$

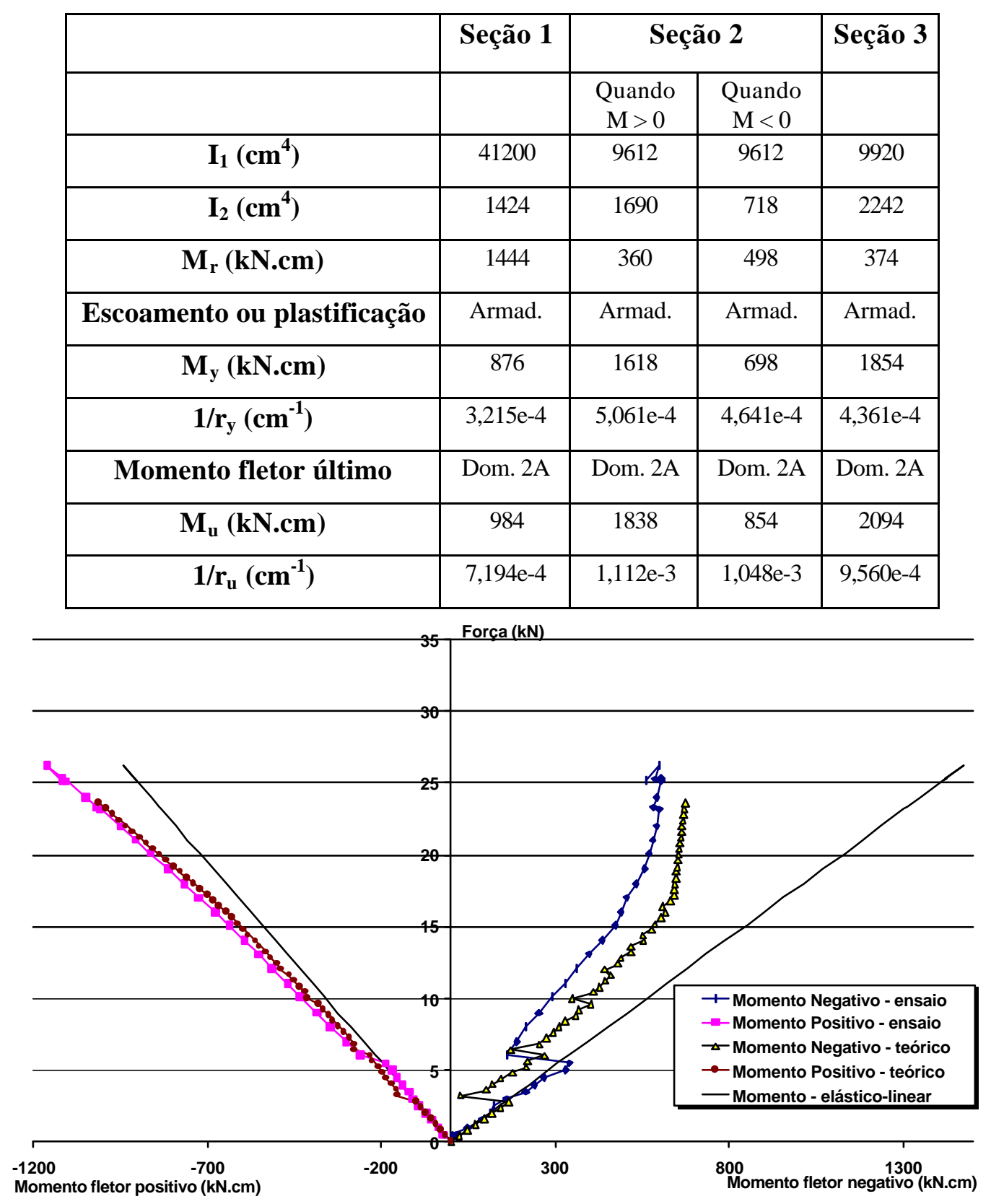

FIGURA 5.11- Máximos momentos fletores - modelo Mac

O último incremento de força na modelagem numérica ocorreu quando foi atingida a capacidade de rotação das rótulas plásticas, capacidade esta limitada ao valor da curvatura última da seção de concreto armado conforme apresentado no item 3.5.1-a. Como a força última de ensaio foi $11 \%$ maior que a força obtida na modelagem numérica, conclui-se que o modelo real apresenta uma capacidade de rotação das rótulas plásticas 
ligeiramente superior ao valor da curvatura última da seção, com as simplificações referentes a este critério.

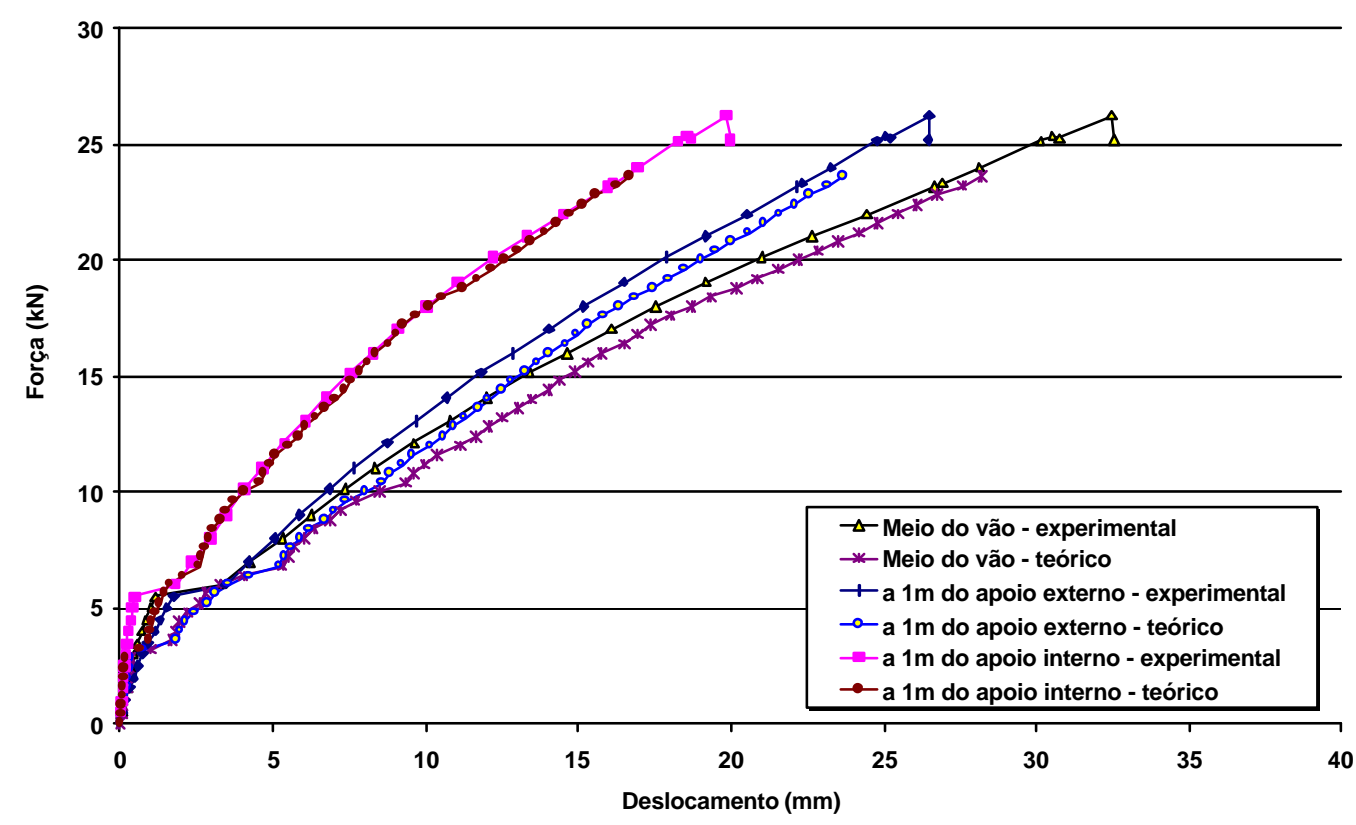

FIGURA 5.12 -Deslocamentos teóricos e experimentais - modelo Mac

Encontrou-se para o momento fletor último negativo obtido com o modelo teórico um valor $13 \%$ maior àquele encontrado no ensaio. Com relação aos graus de redistribuição dos momentos fletores $(\eta)$, foram encontrados respectivamente para os modelos teórico não-linear e experimental $49 \%$ e $59 \%$.

Com relação ao diagrama força $x$ deslocamentos da figura 5.12, assim como também ocorreu nos modelos M15 e M40, os deslocamentos iniciais do modelo Mac para a análise teórico não-linear são maiores que os deslocamentos encontrados no ensaio, fato este decorrente da força em que inicia a fissuração no modelo teórico não-linear ser menor que a força que provocou o início da fissuração no ensaio. Nas etapas seguintes de carga, existe uma tendência dos deslocamentos teóricos e experimentais se igualarem. 


\subsection{Ajustes nos parâmetros do modelo teórico}

Buscando ajustar o modelo teórico não-linear a partir dos resultados obtidos nos ensaios das faixas de lajes, serão apresentados neste item novas modelagens numéricas e comparações de resultados entre o modelo teórico não-linear e os resultados obtidos nos ensaios das faixas de lajes. Para tanto, foi alterado o valor do momento de fissuração nas modelagens numéricas, uma vez que nos ensaios a força que deu início à fissuração experimental foi maior do que aquela encontrada na modelagem numérica descrita no item 5.4. Também foi aumentada a capacidade teórica de rotação das rótulas plásticas dos modelos M40 e Mac (calculada conforme 3.5.1-a), pois a força última experimental para estes modelos foi superior ao valor da força última teórica das modelagens numéricas.

Para ajustar a etapa de carga em que ocorre a fissuração no modelo teórico, aumentou-se a resistência à tração na flexão do concreto em função do momento de fissuração obtido em cada um dos modelos ensaiados. Nestas novas análises, o valor considerado para a resistência à tração na flexão, obtida a partir da resistência à tração na flexão da estrutura real ensaiada, corresponde a 1,7 para os modelos M15 e M40 e 1,85 para o modelo Mac da resistência média à tração do concreto dos corpos-de-prova cilíndricos ensaiados à compressão diametral descritos no item 4.4.1 deste trabalho.

Permitiu-se durante as modelagens numéricas que os modelos M40 e Mac apresentassem capacidade de rotações plásticas superiores aos valores de curvaturas últimas das seções descritas no item 3.5.1-a . Com isto, o novo critério de parada do programa passou a ser a carga última obtida no ensaio (o carregamento no modelo teórico cresce até ser atingido o valor de força última experimental). Através desta nova análise, será possível avaliar a capacidade limite em que o modelo teórico apresenta no desenvolvimento de rotações plásticas.

As comparações entre os resultados dos modelos teóricos com os parâmetros ajustados e os resultados encontrados nos ensaios podem ser vistas nos diagramas das figuras 4.13 a 4.18 . 
Nas novas modelagens numéricas (com a fissuração e a capacidade de rotação das rótulas plásticas ajustadas), o modelo teórico M15 (diagramas das figuras 5.13 e 5.14) atingiu a força última teórica não-linear ao ser criado um mecanismo de colapso no elemento estrutural, ou seja, inicialmente surgiu uma rótula plástica na seção junto ao apoio central e uma etapa de carga depois surgiu uma rótula plástica na seção em que ocorre o máximo momento fletor positivo. O intervalo de carga no qual surgiram estas duas rótulas plásticas teóricas foi tão baixo que não chegou a redistribuir os momentos fletores negativos.

É importante lembrar que na estrutura real as rótulas plásticas não ocorreram em seções discretas, mas em um trecho de comprimento $\ell_{\mathrm{pl}}$ do elemento estrutural.

Para a força de $10 \mathrm{kN}$, que corresponde a solicitação utilizada na verificação de deformações excessivas, os deslocamentos teóricos em todos os modelos analisados são menores que aqueles obtidos no ensaio. Mais uma vez é observado que, no estado limite de utilização referente a deformações excessivas, pode-se considerar a continuidade estrutural em lajes com armação treliçada unidirecionais (que foram calculadas simplesmente apoiadas) desde que exista uma armadura construtiva mínima devidamente posicionada na capa de concreto e ancorada em vãos adjacentes (figuras 4.17 e 4.18).

$\mathrm{Na}$ análise teórica do modelo M15, o deslocamento a $1 \mathrm{~m}$ do eixo do apoio externo foi ligeiramente maior que o deslocamento no meio do vão. Esta situação não foi captada no ensaio, uma vez que os deslocamentos no meio do vão e a $1 \mathrm{~m}$ do eixo do apoio externo possuem valores bem próximos.

Nos modelos M40 e Mac são verificados bons ajustes nos diagramas força $x$ deslocamento e força $x$ momentos fletores, conforme pode ser visto nas figuras 5.15 a 5.18. Os deslocamentos últimos, teóricos e experimentais, nas seções instrumentadas praticamente coincidem. 


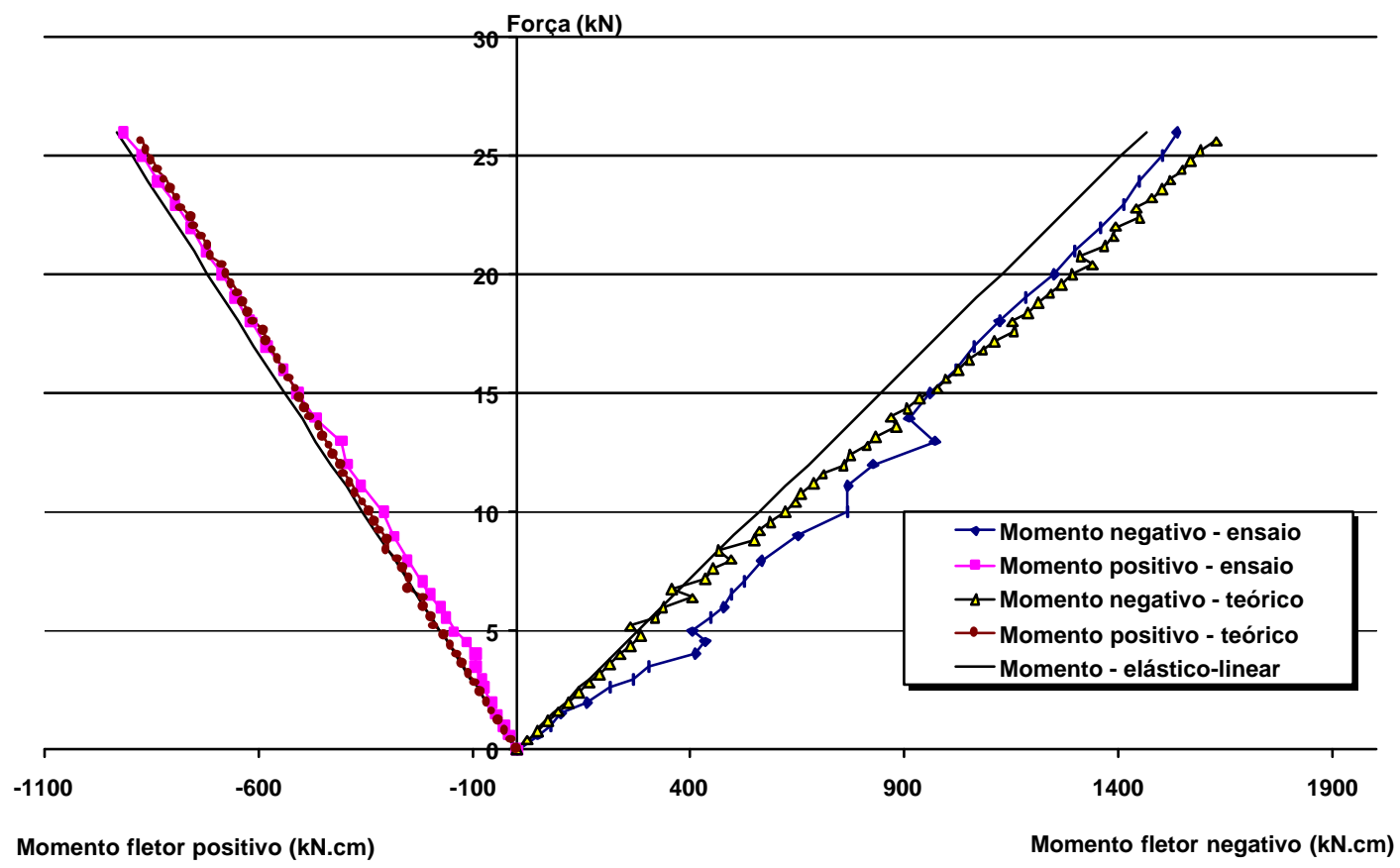

FIGURA 5.13- Momentos fletores com resistência à tração e capacidade de rotação ajustados - modelo M15

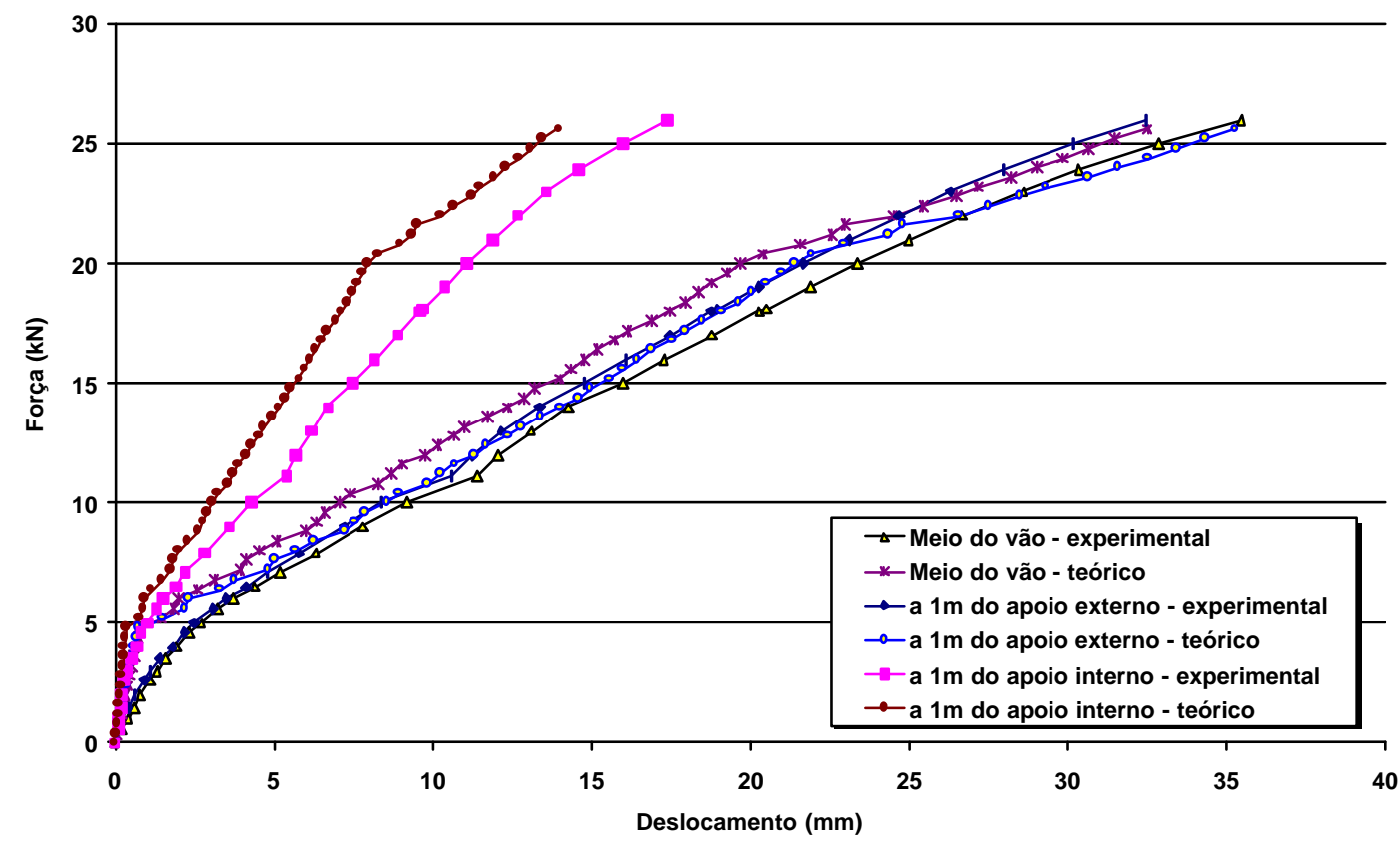

FIGURA 5.14 - Deslocamentos com resistência à tração e capacidade de rotação ajustados - modelo M15 


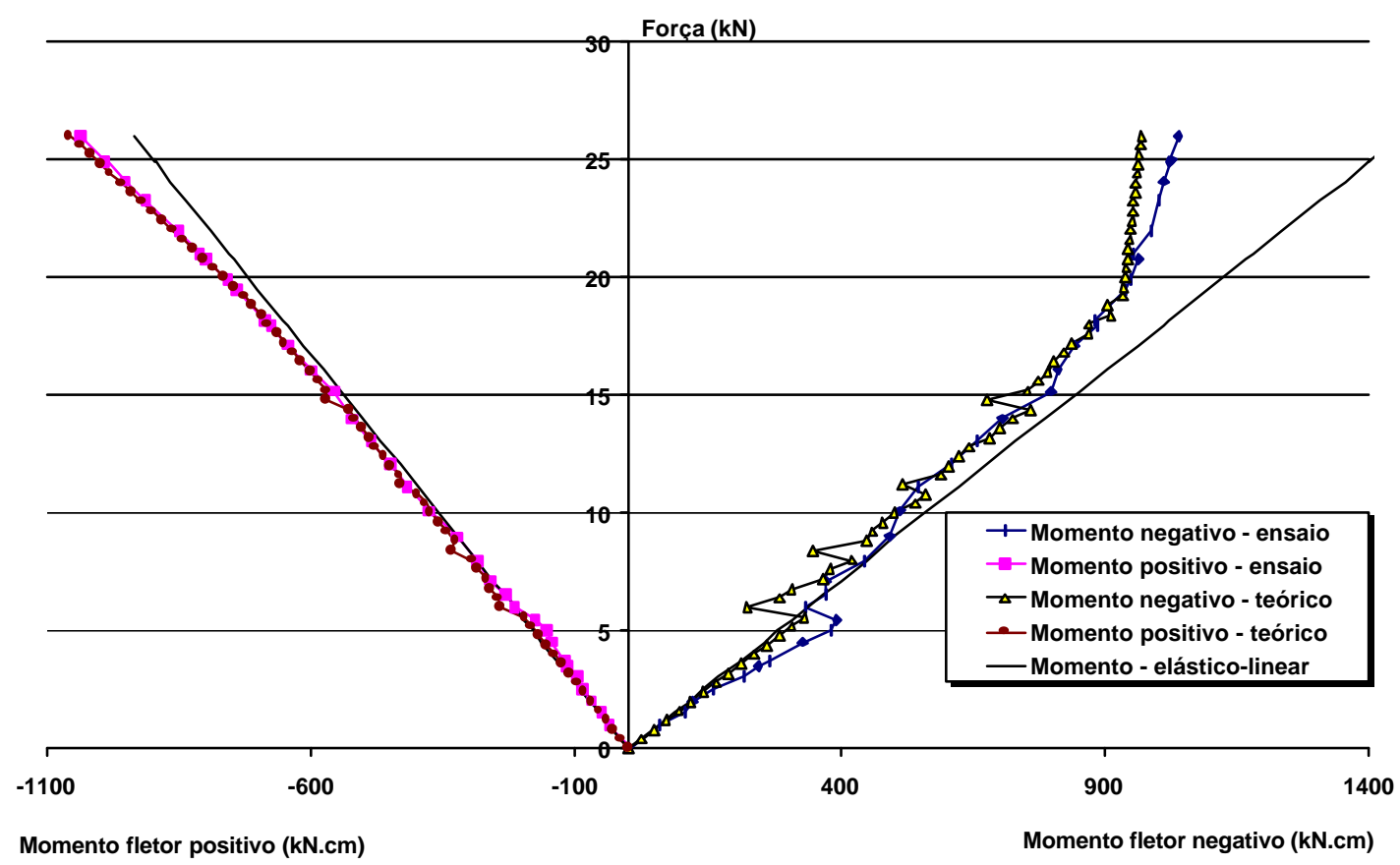

FIGURA 5.15 - Momentos fletores com resistência à tração e capacidade de rotação ajustados - modelo M40

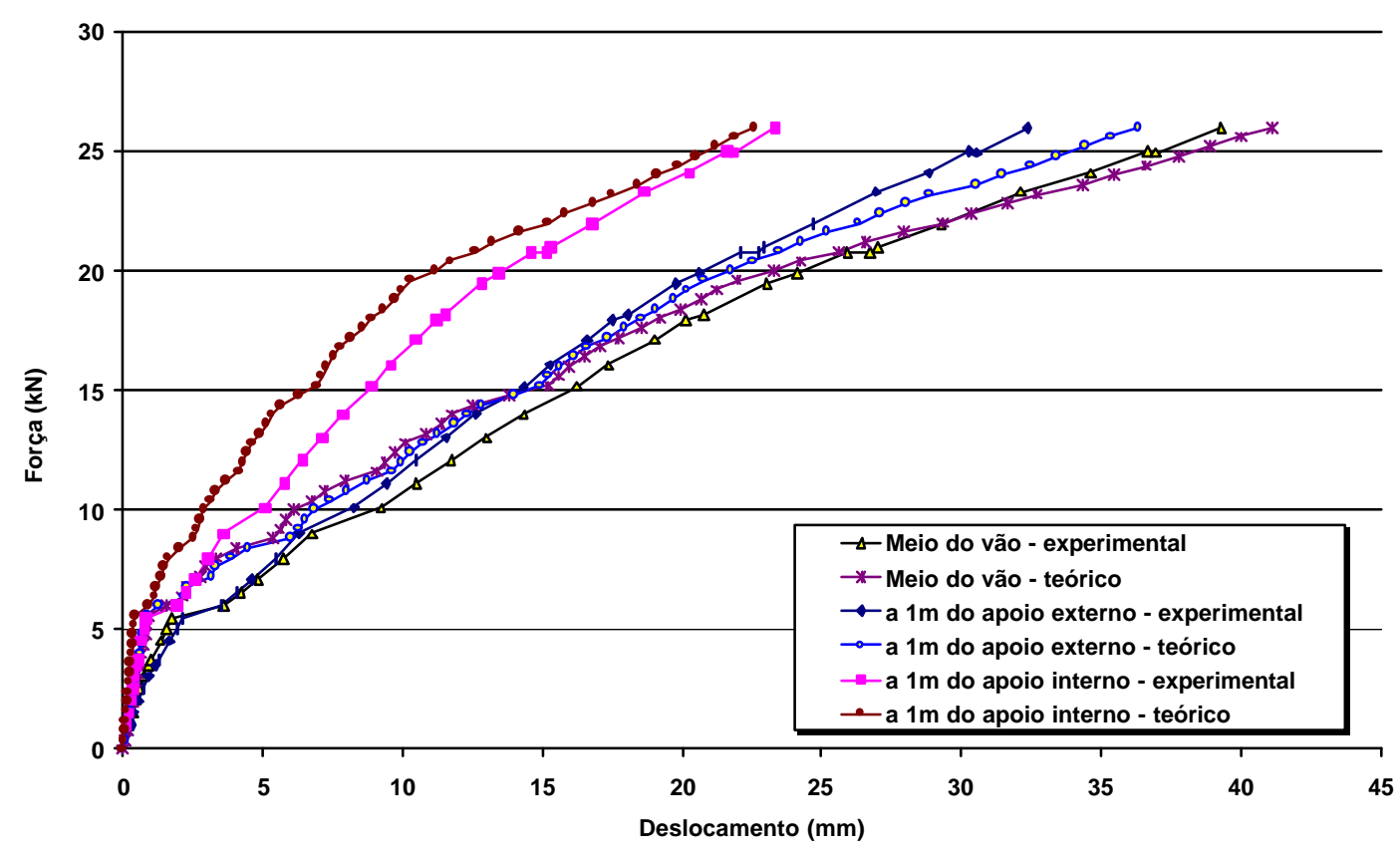

FIGURA 5.16 - Deslocamentos com resistência à tração e capacidade de rotação ajustados - modelo M40 


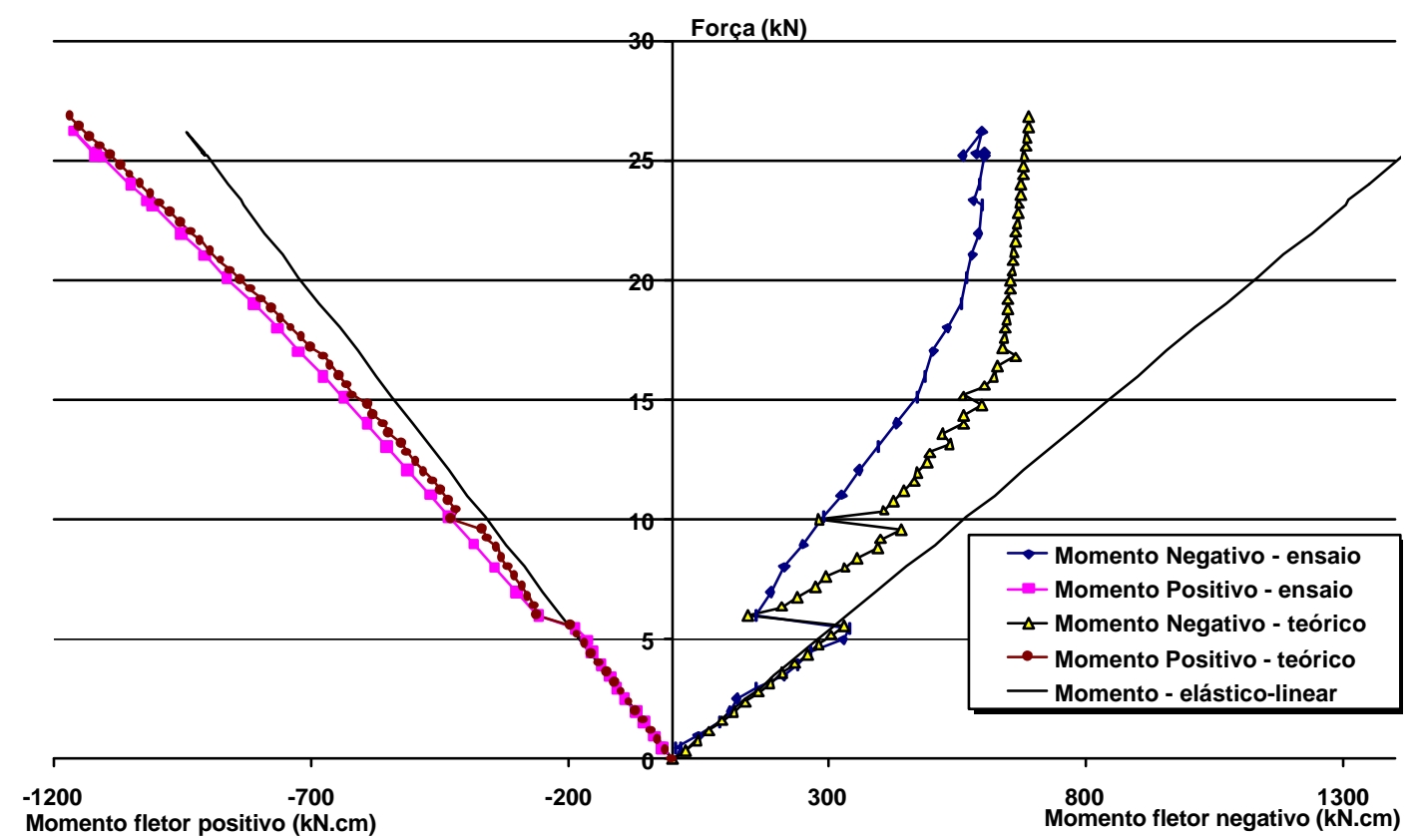

FIGURA 5.17 - Momentos fletores com resistência à tração e capacidade de rotação ajustados - modelo Mac

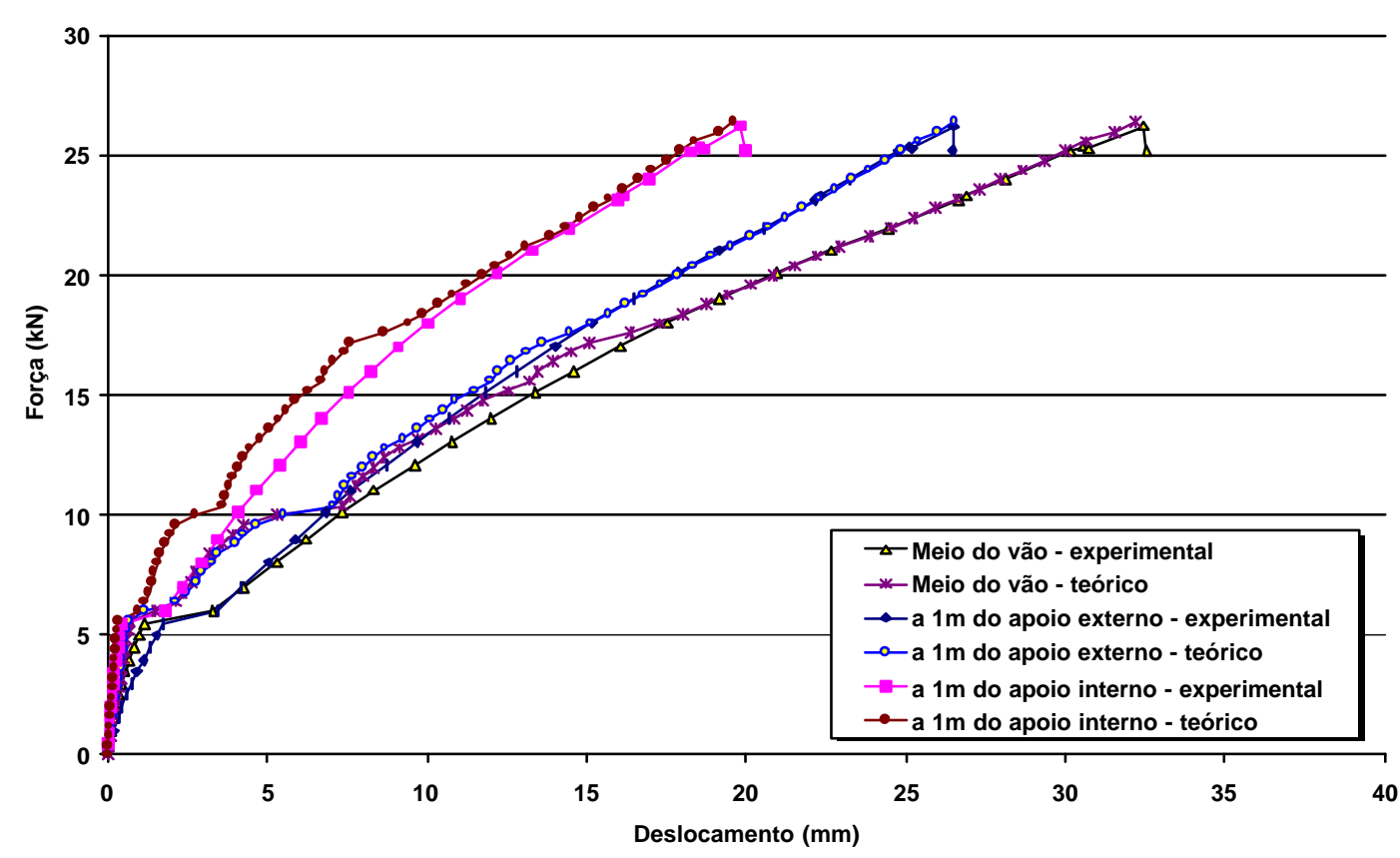

FIGURA 5.18 - Deslocamentos com resistência à tração e capacidade de rotação ajustados - modelo Mac 
Na figura 5.19 está apresentado o diagrama momento fletor $x$ curvatura dos modelos teóricos Mac e M40. Estes diagramas foram construídos para as seções teóricas críticas das rótulas plásticas, ou seja, de acordo com as modelagens numéricas, estas seções correspondem àquelas situadas a $10 \mathrm{~cm}$ do eixo do apoio central (seções B e D da figura 4.39).

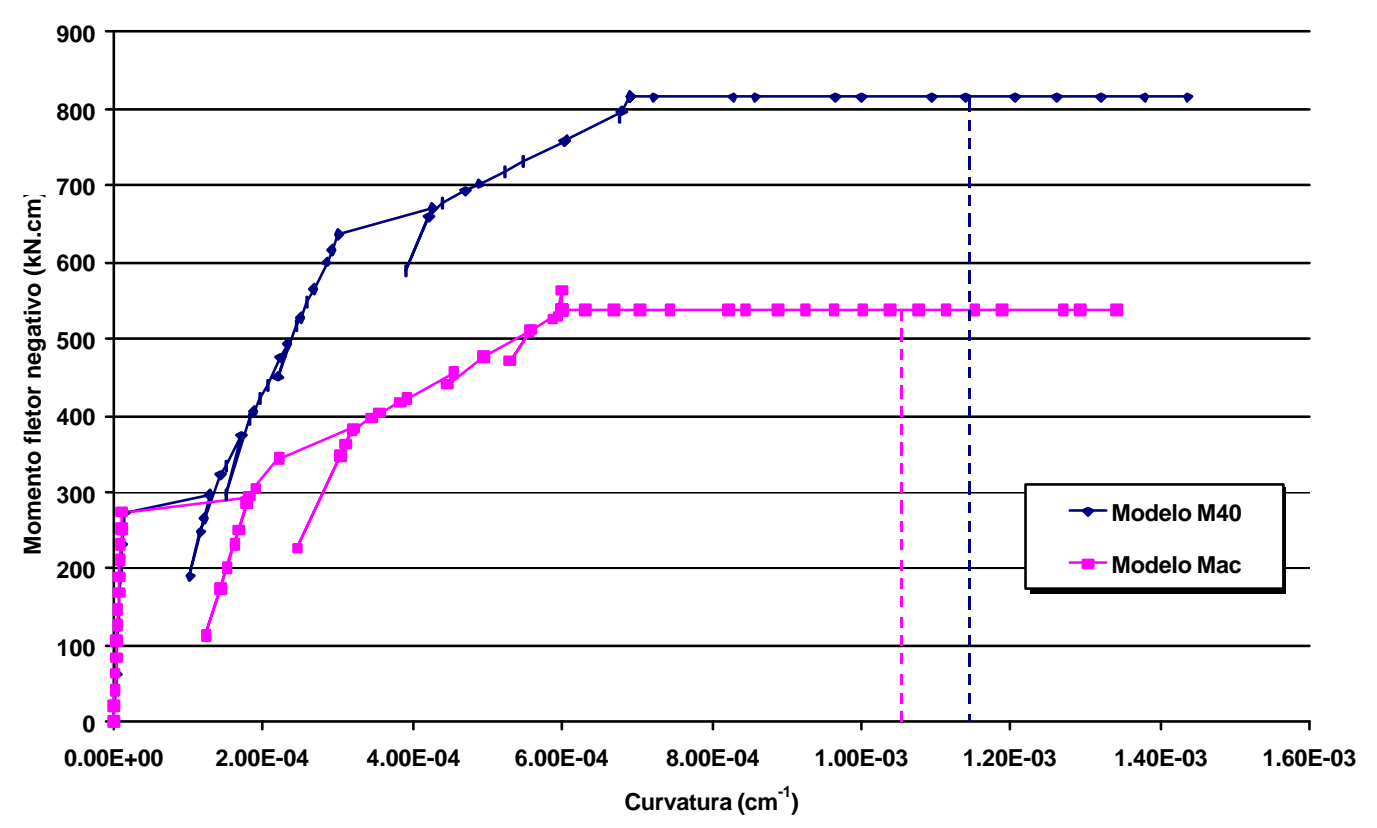

FIGURA 5.19 - Diagrama momento $x$ curvatura teórico

Para os modelos teóricos M40 e Mac atingirem nas modelagens numéricas o valor da força última de ensaio $(\approx 26 \mathrm{kN})$, as rótulas plásticas devem apresentar uma capacidade de rotação $28 \%$ maior que a capacidade de rotação considerada com o critério apresentado no item 3.5.1-a deste trabalho.

É importante lembrar que a curvatura média medida a partir dos deslocamentos depende da discretização do elemento estrutural. Com isto, se os modelos M40 e Mac fossem discretizados em elementos cada vez menores, também menores seriam os ajustes no critério teórico que estima capacidade de rotação plástica, uma vez que a curvatura teórica média no trecho analisado estaria mais próxima da curvatura real da seção teórica plastificada.

Para ilustrar o efeito da discretização na curvatura média, seja o arco hipotético da figura 5.20. A curvatura da seção B calculada a partir da curvatura média do 
arco $\mathrm{ABC}$ é de 0,0123 unidade $^{-1}$. Se a curvatura da seção $\mathrm{B}$ fosse calculada a partir da curvatura média do arco DBE seria encontrado o valor de 0,0110 unidade $^{-1}$, ou seja, $10 \%$ menor que no caso anterior. À medida que a corda do arco vai diminuindo, a curvatura média converge ao valor da curvatura da seção B.

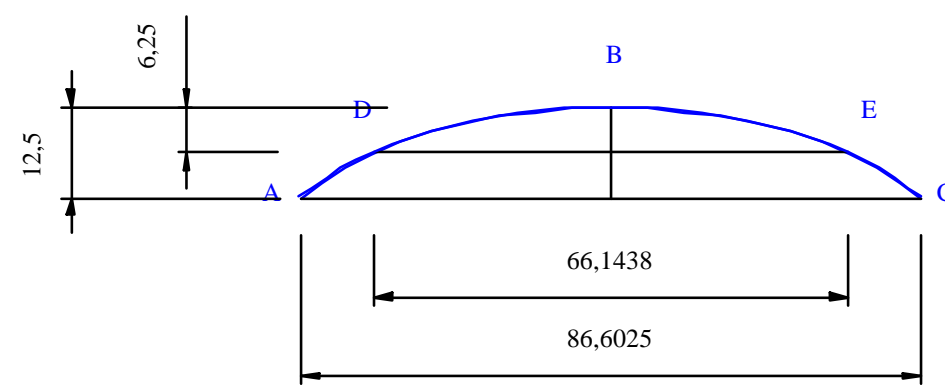

Arco ABC:

$$
1 / \mathrm{r}_{\text {média }}=0,0123 \text { unidade }^{-1}
$$

Arco DBE:

$$
1 / \mathrm{r}_{\text {média }}=0,0110 \text { unidade }^{-1}
$$

FIGURA 5.20- Efeito da discretização na curvatura média

Na figura 5.21 estão apresentados os diagramas momento fletor $x$ curvatura teórico e experimental para os modelos Mac e M40.

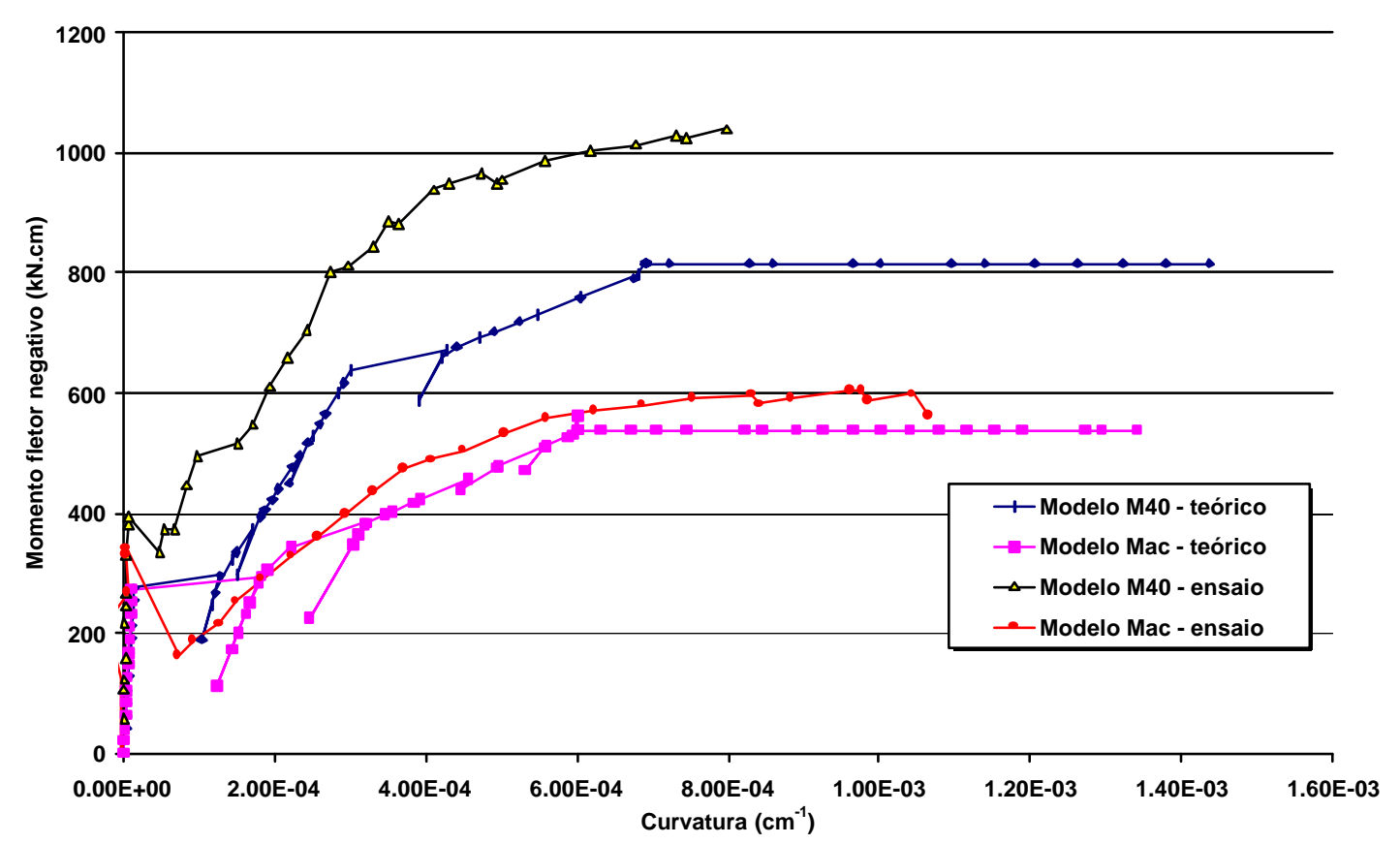

FIGURA 5.21 - Diagrama momento $x$ curvatura obtido com os dados de ensaio

Percebe-se na figura 5.21 que o diagrama momento $x$ curvatura teórico do modelo Mac está bem ajustado com o diagrama experimental. Com relação ao modelo M40, os resultados das análises teóricas e experimentais não foram tão próximos como 
observado no modelo Mac. Entretanto, percebe-se que estes diagramas apresentam comportamentos semelhantes.

A possível causa na diferença encontrada nos valores últimos destes diagramas decorre que as curvaturas médias nos modelos teórico e experimental foram medidas em trechos com diferentes comprimentos do elemento estrutural, e além disso, a relação momento $x$ curvatura no modelo teórico é feita para uma seção a $10 \mathrm{~cm}$ do eixo do apoio central (seção crítica do modelo teórico) ao passo que no modelo experimental a mesma relação é feita para um trecho no qual o apoio central está contido.

Comparando-se os valores da capacidade de rotação das rótulas plásticas obtidos nas simulações numéricas com parâmetros ajustados com os valores de capacidade de rotação das rótulas plásticas obtidos com o modelo teórico de DarmstadtLeipzig publicado no CEB (1998), encontram-se os resultados mostrados na tabela 5.5.

TABELA 5.5 - Comparações entre capacidade de rotações plásticas

\begin{tabular}{|c|c|c|}
\hline \multirow{2}{*}{} & \multicolumn{2}{|c|}{ Rotações plásticas $\left(\boldsymbol{\theta}_{\text {pl }}\right)$ em rad } \\
\cline { 2 - 3 } & M40 & Mac \\
\hline a- Modelagem numérica com ajustes & $2,84 \mathrm{e}-2$ & $2,84 \mathrm{e}-2$ \\
\hline b- Modelo de Darmstadt-Leipzig & $2,79 \mathrm{e}-2$ & $2,94 \mathrm{e}-2$ \\
\hline Relação a / b & 1,02 & 0,97 \\
\hline
\end{tabular}

De acordo com esta tabela, ao serem comparados os valores da capacidade de rotação das rótulas plásticas das modelagens numéricas com parâmetros ajustados aos valores da capacidade das rotações plásticas calculados com o modelo teórico de Darmstadt-Leipzig, as diferenças entre as capacidade de rotações plásticas são pequenas, mostrando que o modelo teórico de Darmstadt-Leipzig representa bem a capacidade de rotações plásticas em lajes nervuradas.

Nas figuras 5.22, 5.23 e 5.24 podem ser vistos, respectivamente, os diagramas da força $x$ rigidez à flexão para os modelos M15, M40 e Mac, diagramas estes encontrados na modelagem numérica destes modelos. As seções para os quais estes diagramas foram construídos correspondem àqueles onde atuam o máximo momento fletor positivo (seção A da figura 4.38: a 1m do eixo do apoio externo) e seção crítica teórica na 
qual são formadas as rótulas plásticas (seção B da figura 4.39: a 10cm do eixo do apoio central).

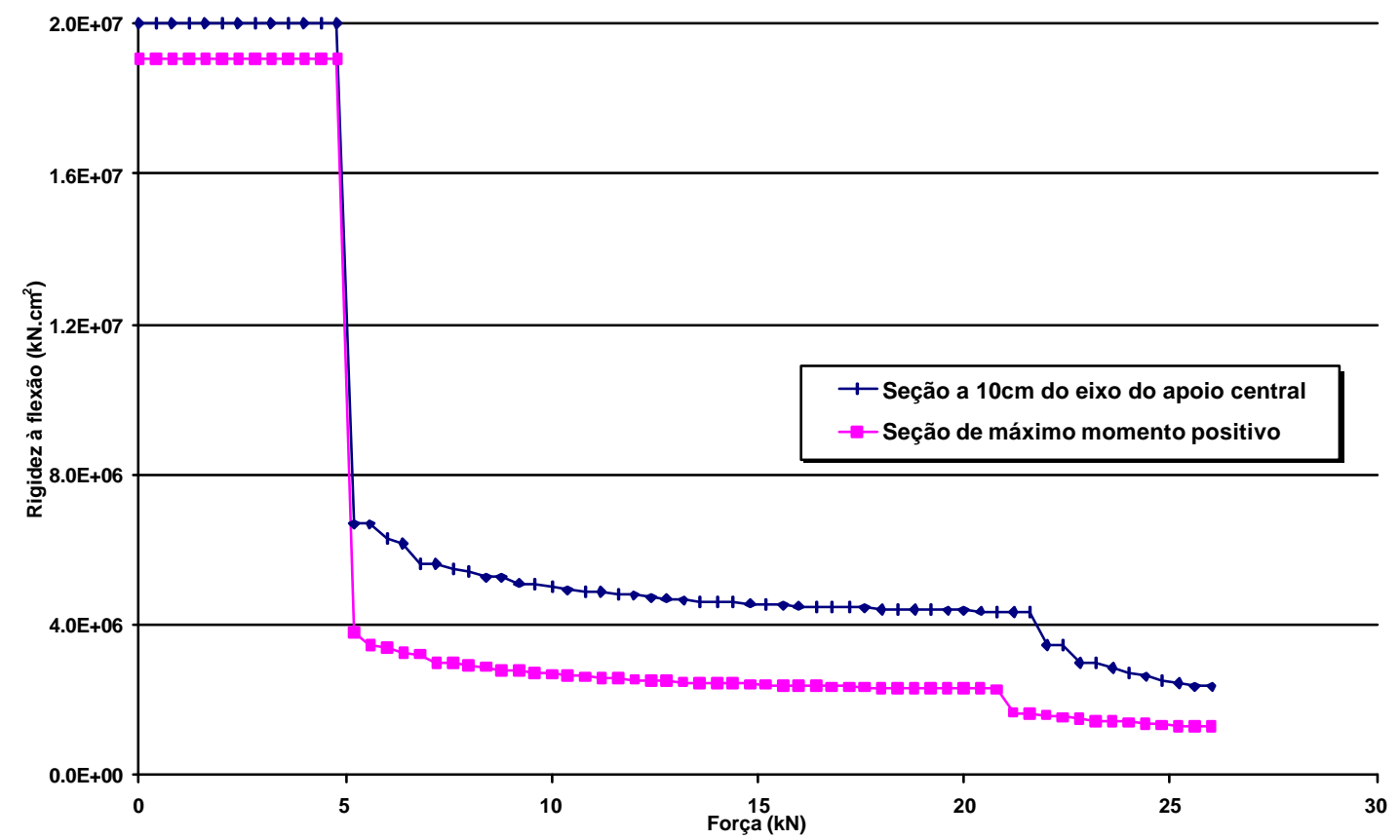

FIGURA 5.22- Rigidez à flexão $x$ força aplicada - análise teórica do modelo M15

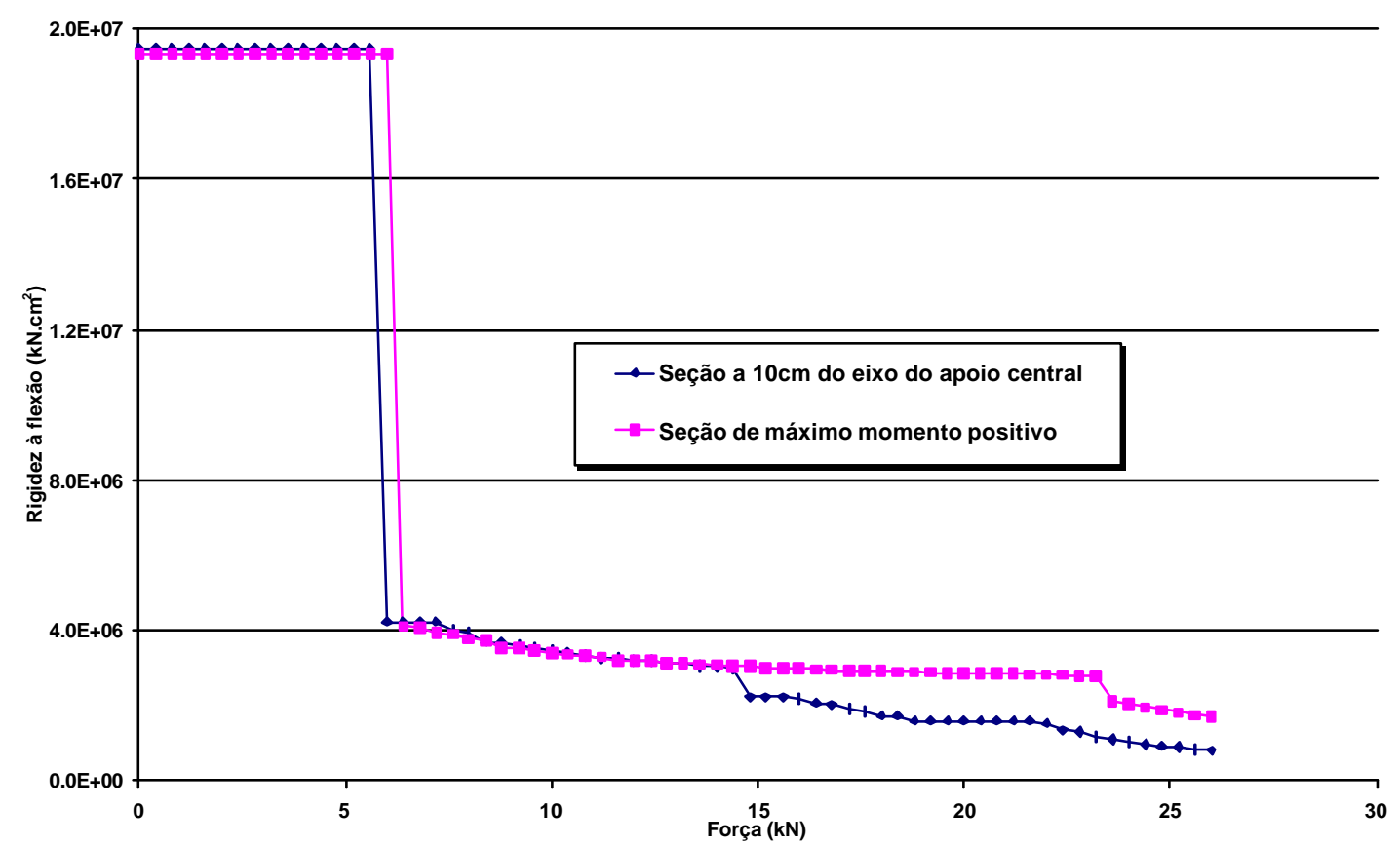

FIGURA 5.23- Rigidez à flexão $x$ força aplicada - análise teórica do modelo M40 


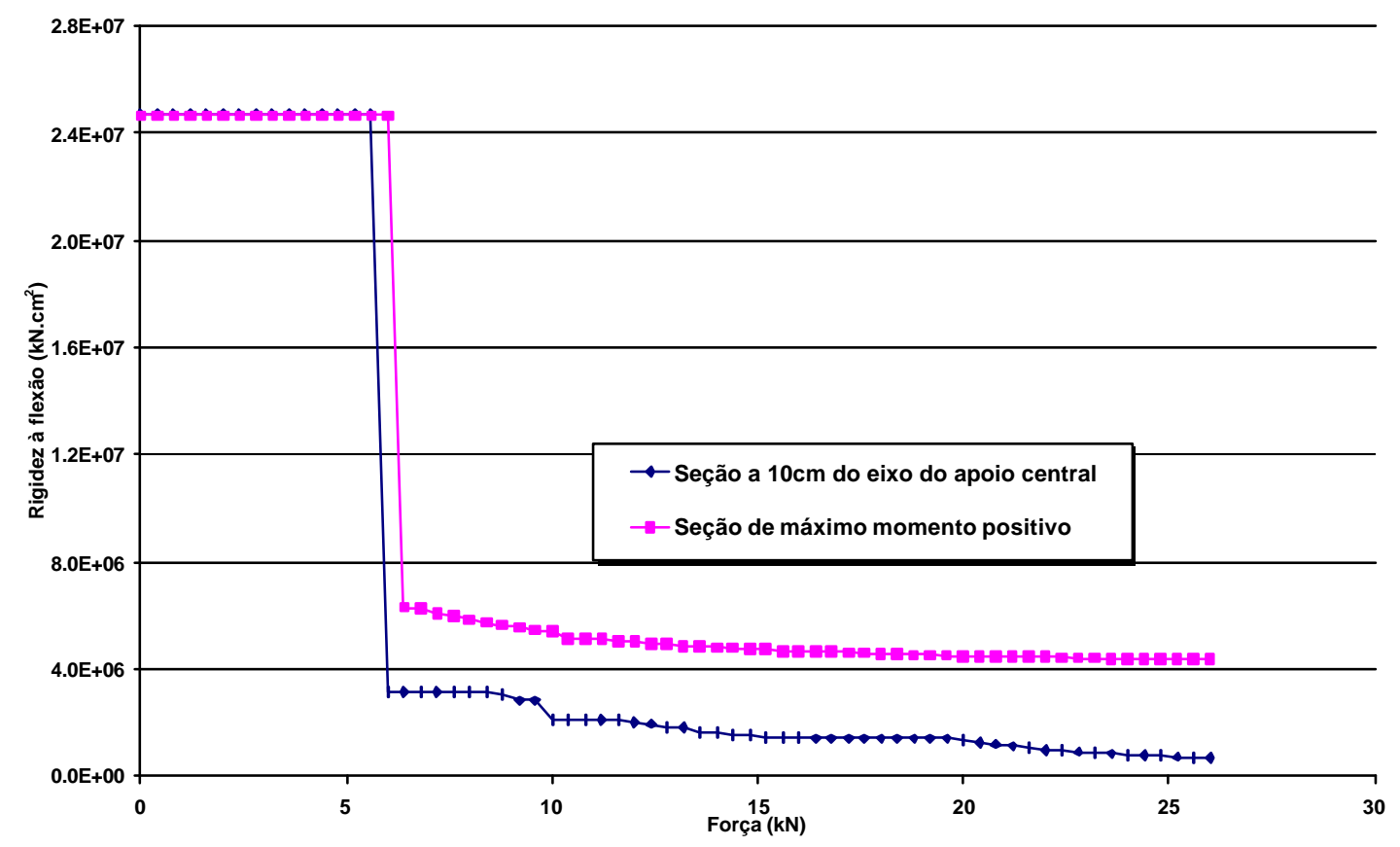

FIGURA 5.24- Rigidez à flexão $x$ força aplicada - análise teórica do modelo Mac

De acordo com os diagramas força $x$ rigidez à flexão, verificam-se que nos estados iniciais de carga, as seções onde ocorrem os momentos fletores negativos são mais rígidas que as seção onde atuam os momentos fletores positivos. Isto porque na homogeneização de seções, para o cálculo da inércia no estádio I, as seções junto aos apoios internos apresentam, além da armadura negativa tracionada, a armação treliçada e armaduras adicionais do elemento pré-moldado. Pode ser verificado nestes diagramas que, quanto maior a área de armadura negativa, maior também será a diferença entre as rigidezes à flexão nas seções onde atuam momentos fletores positivos e negativos.

Com as seções dos apoios centrais mais rígidas, antes de iniciar a fissuração os modelos apresentam momentos fletores negativos maiores àqueles obtidos na análise elástico-linear e rigidez constante. À medida que a taxa de armadura negativa é aumentada, maiores são as diferenças dos momentos fletores negativos não-lineares aos momentos fletores negativos calculados na fase elástica-linear com rigidez constante (elemento não fissurado).

Observa-se nos mesmos diagramas que o início da fissuração nas seções próximas ao apoio central e seção de máximo momento fletor positivo ocorre praticamente 
na mesma etapa de carga. Após a fissuração dos modelos, a evolução dos momentos fletores dependerá da rigidez das seções, que por sua vez depende da taxa de armadura.

No modelo M15, verifica-se que a seção na qual surge a rótula plástica teórica (a $10 \mathrm{~cm}$ do eixo do apoio central) sempre é mais rígida que a seção onde atua o máximo momento fletor positivo. Então, realmente não seria de se esperar redistribuição de momentos fletores negativos e, mais uma vez confirmado pelos resultados de ensaios, surgirem nas estruturas momentos fletores negativos não-lineares com valores superiores àqueles obtidos na análise elástico-linear e rigidez constante em todas as etapas de carga.

No modelo M40 observa-se que no estádio I as seções com máximos momentos fletores positivos e negativos apresentam valores de rigidezes muito próximos. Porém, com o aumento da força aplicada a rigidez das seções próximas ao apoio central vai diminuindo em relação à rigidez do ponto de máximo momento fletor positivo. Este ponto equivale a uma força aplicada com o valor em torno de $15 \mathrm{kN}$, ou seja, no instante em que ocorre uma redistribuição de esforços mais significativa, conforme pode ser observado no diagrama força $x$ momentos fletores da figura 5.15 .

No estádio I, o modelo Mac apresentou a menor diferença entre as rigidezes à flexão na seção crítica do apoio central e seção de máximo momento fletor positivo uma vez que este elemento estrutural possui a menor taxa de armadura negativa. Ao ser atingido o estádio II, a rigidez da seção onde aparece a rótula plástica teórica junto ao apoio central apresenta uma queda mais significativa que a rigidez da seção de máximo momento fletor positivo. Com isto, redistribuição de esforços sempre é verificada a partir da fissuração do elemento estrutural.

Os deslocamentos teóricos ao longo do eixo longitudinal dos modelos M15, M40 e Mac podem ser vistos nos diagramas das figuras 5.25, 5.26 e 5.27.

Para a força aplicada correspondente a ação do estado limite de utilização referente à verificação de deformações excessivas $(10 \mathrm{kN})$, verificam-se que os deslocamentos máximos (flecha) apresentados pelos três modelos analisados localiza-se no trecho do elemento estrutural próximo a coordenada $130 \mathrm{~cm}$. Até mesmo o modelo que foi dimensionado simplesmente apoiado com armadura construtiva junto aos apoios (modelo 
Mac) apresenta, para forças de serviço, deslocamentos com comportamento de uma estrutura que possui continuidade estrutural no apoio central.

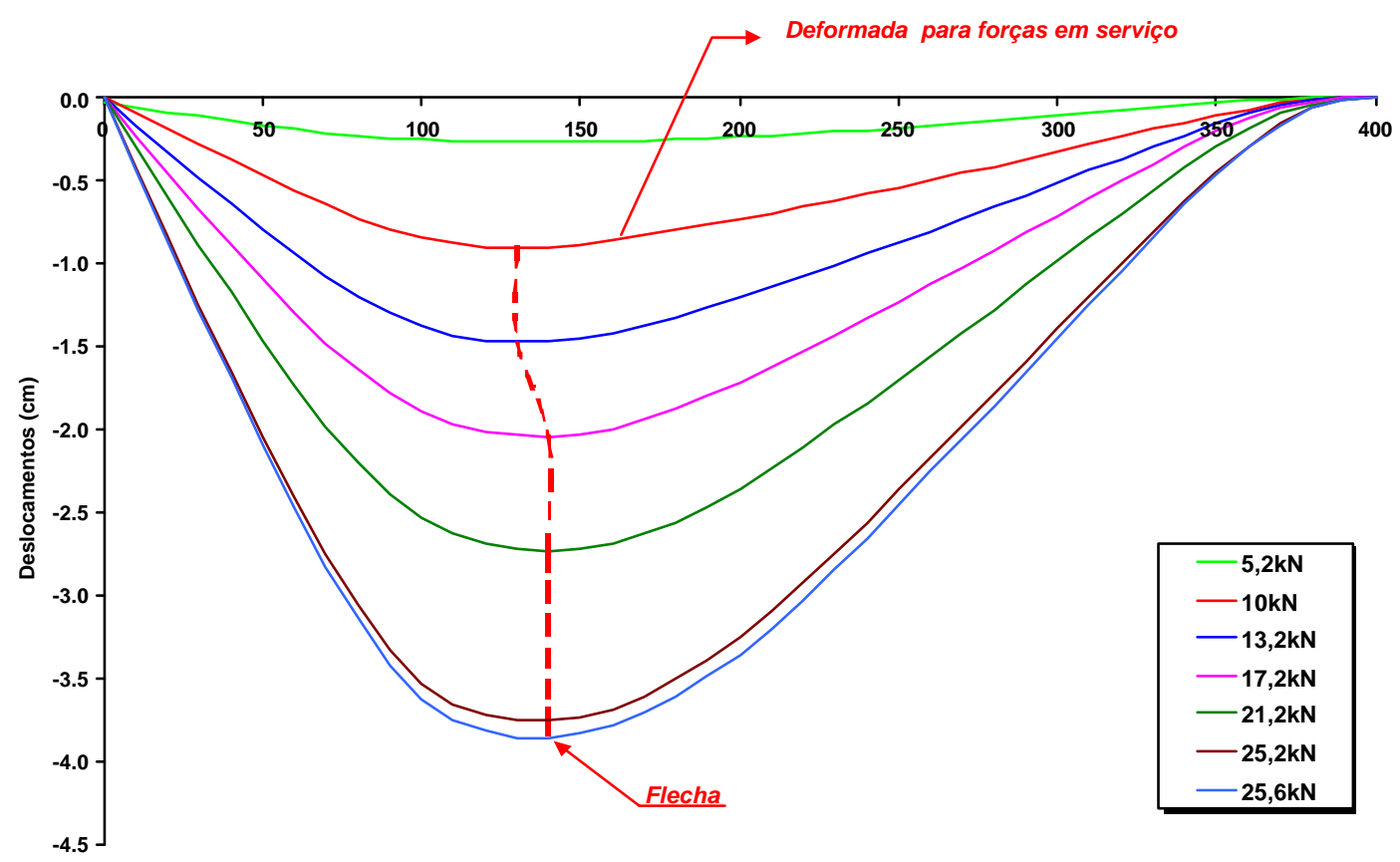

FIGURA 5.25 - Evolução dos deslocamentos teóricos -modelo M15

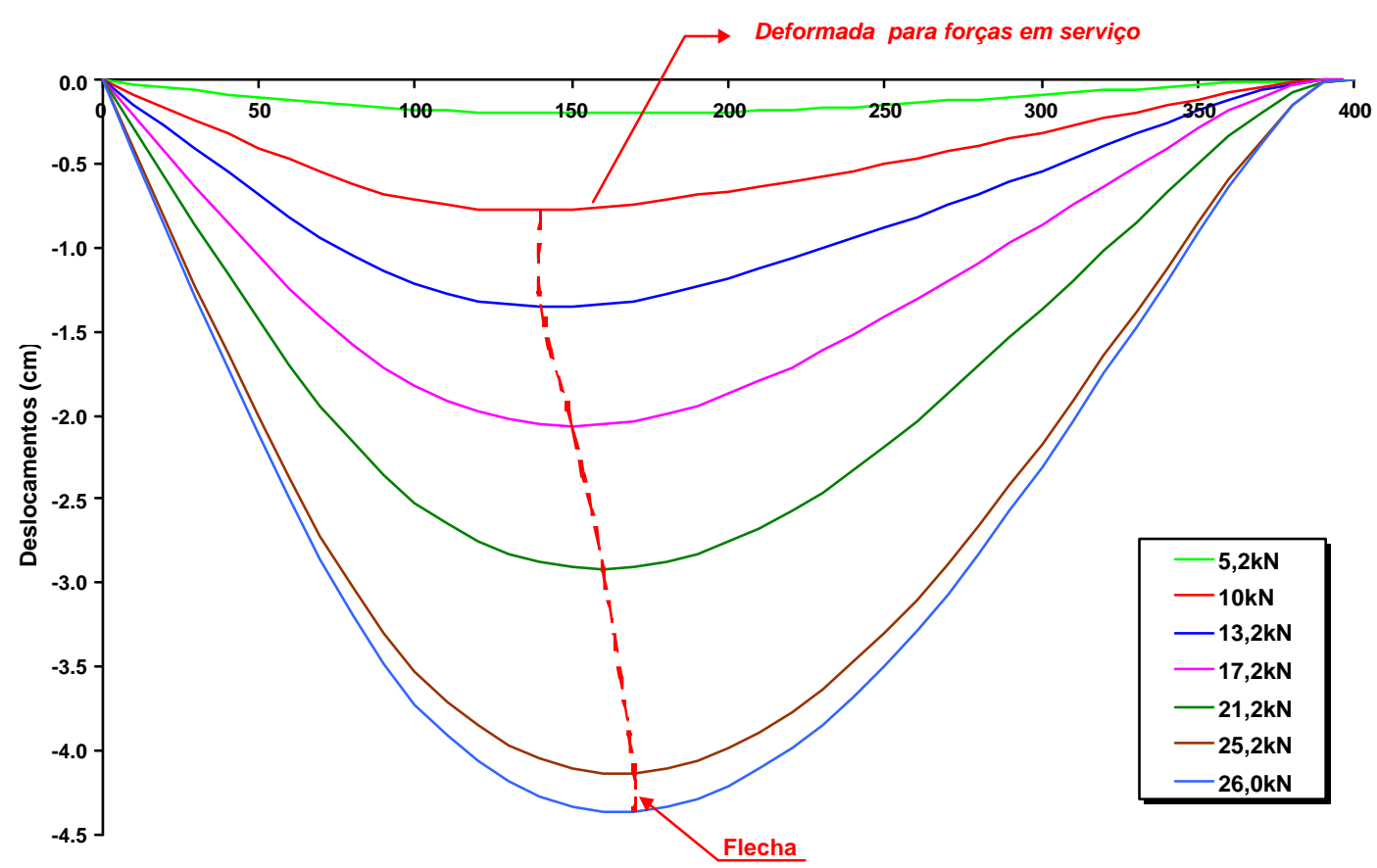

FIGURA 5.26 - Evolução dos deslocamentos - Análise teórica do modelo M40 


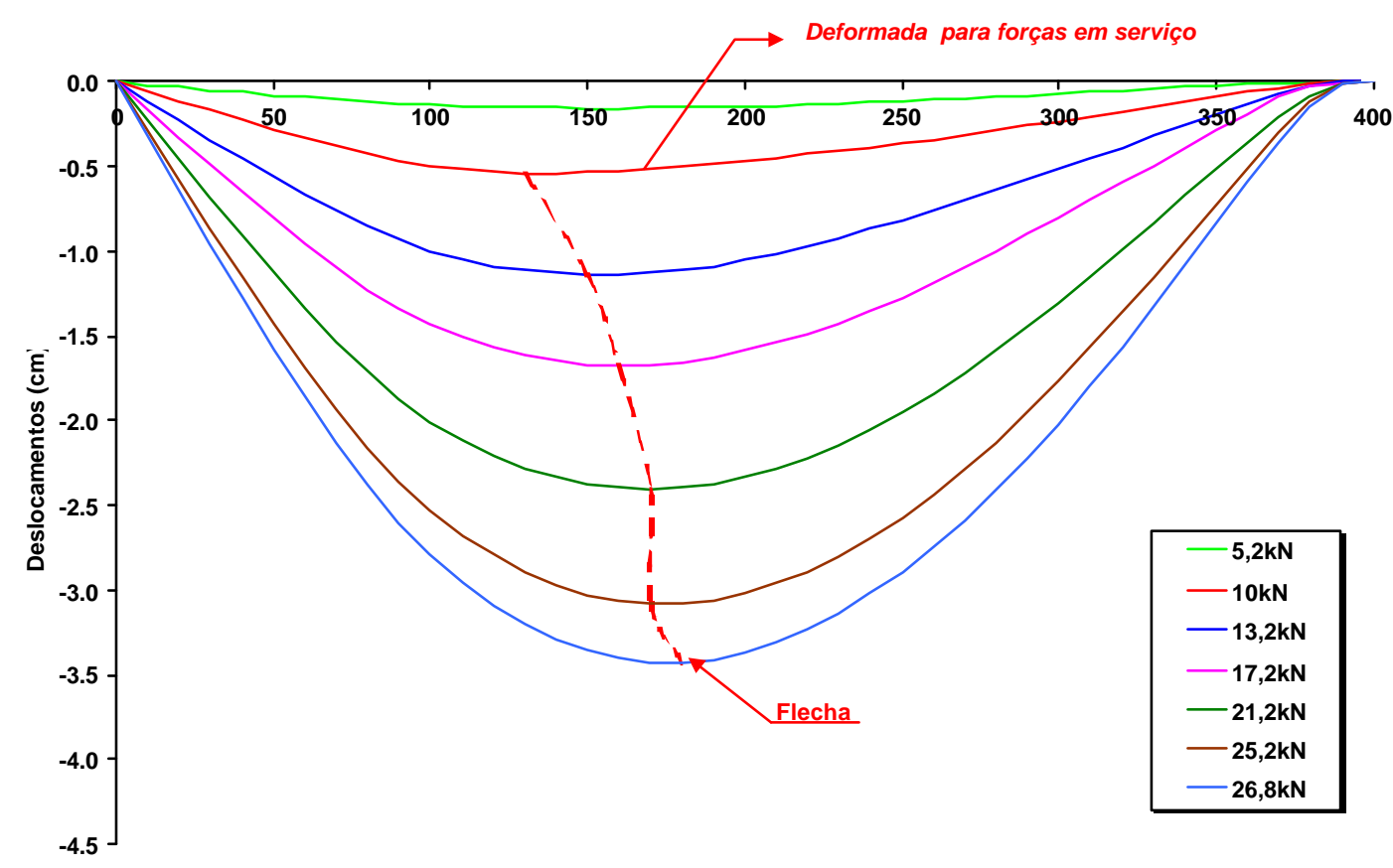

FIGURA 5.27 - Evolução dos deslocamentos - Análise teórica do modelo Mac

Embora os modelos tenham sido analisados com diferentes taxas de armaduras nas suas seções, os deslocamentos máximos de serviço possuem valores próximos.

Nas etapas posteriores de carga, percebe-se que os deslocamentos teóricos máximos nos modelos deslocam-se da coordenada $130 \mathrm{~cm}$ em direção ao meio do vão. Este fato é mais evidente quanto menor for a taxa de armadura negativa. Então, nos estados limites últimos, os deslocamentos máximos em lajes nervuradas estarão mais próximos do meio do vão quanto maior for o grau de redistribuição $\eta$ adotado no dimensionamento destas lajes.

\subsection{Estimativa do comportamento do modelo M0}

Este item apresenta a modelagem numérica de uma faixa de laje nervurada formada por vigotas pré-moldadas dimensionadas sem redistribuição dos momentos fletores negativos (modelo M0). 
As dimensões deste modelo são aquelas apresentadas nas figuras 4.1, 4.2 e 4.3 .

O dimensionamento da armadura de flexão foi realizado conforme apresentado em 4.2.2 com a particularidade de não se considerar momentos fletores redistribuídos nesta fase. Na tabela 5.6 está mostrada a amadura de flexão do modelo M0.

TABELA 5.6 - Armaduras de flexão do modelo M0

\begin{tabular}{|c|c|c|c|c|}
\hline \multirow{2}{*}{$\begin{array}{c}\text { Armadura } \\
\text { negativa }\end{array}$} & \multirow{2}{*}{$\begin{array}{c}\text { Armação } \\
\text { treliçada }\end{array}$} & \multirow{2}{*}{$\begin{array}{c}\text { Armadura } \\
\text { adicional }\end{array}$} & \multicolumn{2}{|c|}{$\begin{array}{c}\text { Consumo da armadura de } \\
\text { flexão (kg) }\end{array}$} \\
\cline { 4 - 5 } & & & s/ treliça & c/ treliça \\
\hline $10 \phi 6,0$ & TR08634 & $2 \phi 3,4+1 \phi 4,2$ & 9,36 & 19,36 \\
\hline
\end{tabular}

As características mecânicas dos materiais adotadas neste modelo são as mesmas adotadas nas modelagens numéricas dos modelos M15, M40 e Mac, descritas no item 4.4. Consideraram-se ainda no modelo teórico as idealizações apresentadas em 5.3 e os ajustes do item 5.5.

Na tabela 5.7 estão apresentadas as características mecânicas e geométricas das seções de referência da figura 5.6 para o modelo teórico M0.

TABELA 5.7 - Características geométricas e mecânicas das seções de referência- modelo M0

\begin{tabular}{|c|c|c|c|c|}
\hline & Seção 1 & \multicolumn{2}{|c|}{ Seção 2} & Seção 3 \\
\hline & & $\begin{array}{c}\text { Quando } \\
M>0\end{array}$ & $\begin{array}{c}\text { Quando } \\
\mathrm{M}<0\end{array}$ & \\
\hline$I_{1}\left(\mathrm{~cm}^{4}\right)$ & 35200 & 7776 & 7776 & 7558 \\
\hline$I_{2}\left(\mathrm{~cm}^{4}\right)$ & 4400 & 1062 & 1994 & 1060 \\
\hline $\mathbf{M}_{\mathbf{r}}(\mathbf{k N . c m})$ & 1872 & 438 & 640 & 432 \\
\hline Escoamento ou plastificação & Armad. & Armad. & Armad. & Armad. \\
\hline$M_{y}(k N . c m)$ & 2638 & 919 & 1934 & 918 \\
\hline $1 / r_{y}\left(\mathrm{~cm}^{-1}\right)$ & $3,29 \mathrm{e}-4$ & $4,50 \mathrm{e}-4$ & $4,85 \mathrm{e}-4$ & $4,54 \mathrm{e}-4$ \\
\hline Momento fletor último & Dom 2A & Dom 2A & Dom 2B & Dom 2A \\
\hline$M_{u}(k N . c m)$ & 2946 & 1032 & 2152 & 1034 \\
\hline $1 / r_{u}\left(\mathrm{~cm}^{-1}\right)$ & $7,58 \mathrm{e}-4$ & $1,00 \mathrm{e}-3$ & $1,10 \mathrm{e}-3$ & $1,01 \mathrm{e}-3$ \\
\hline
\end{tabular}


$\mathrm{Na}$ figura 5.28 podem ser vistos os diagramas força $x$ momentos fletores teóricos para os modelos M0, M15, M40 e Mac. A força última teórica em todos os modelos, inclusive no modelo M0 foi de aproximadamente $26 \mathrm{kN}$. Vê-se que o comportamento dos momentos fletores apresentado pelo modelo teórico M0 confirma o que foi discutido no item 5.2 deste trabalho. Este modelo não apresenta redistribuição dos momentos fletores negativo em nenhum momento da sua análise não-linear. Nas últimas etapas de carga, a relação entre os momentos fletores negativos obtidos a partir da análise não-linear e aqueles obtidos a partir da análise elástico-linear com rigidez constante $\left(\mathrm{M}_{\text {não- }}\right.$ linear $\left./ \mathrm{M}_{\text {elástico-linear }}\right)$ para o modelo M0 é de aproximadamente 1,26.

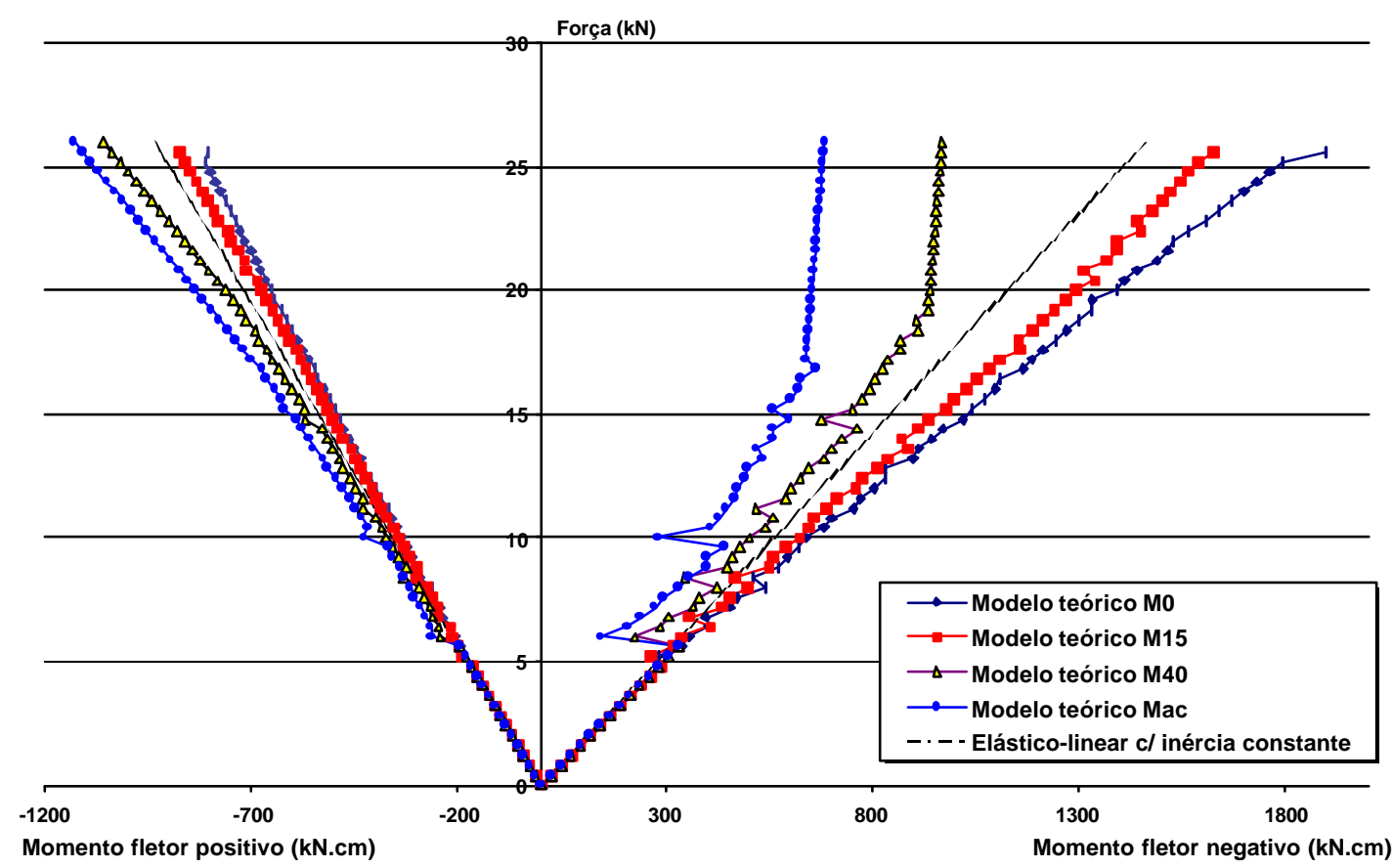

FIGURA 5.28 - Máximos momentos fletores teóricos dos modelos M0, M15, M40 e Mac

Na figura 5.29 têm-se os deslocamentos teóricos do modelo M0 em função da força aplicada. Observa-se que para as forças na ordem de grandeza daquelas utilizadas na verificação do estado limite de deformação excessiva $(\approx 10 \mathrm{kN})$, deslocamentos teóricos do modelo M0 estão próximos daqueles encontrados nos demais modelos analisados neste trabalho. Nos estados finais do carregamento incremental (quando a força última atinge $26 \mathrm{kN}$ ), vê-se na figura 5.29 que os deslocamentos teóricos do modelo M0 não distanciam daqueles encontrados nos modelos M15, M40 e Mac. 


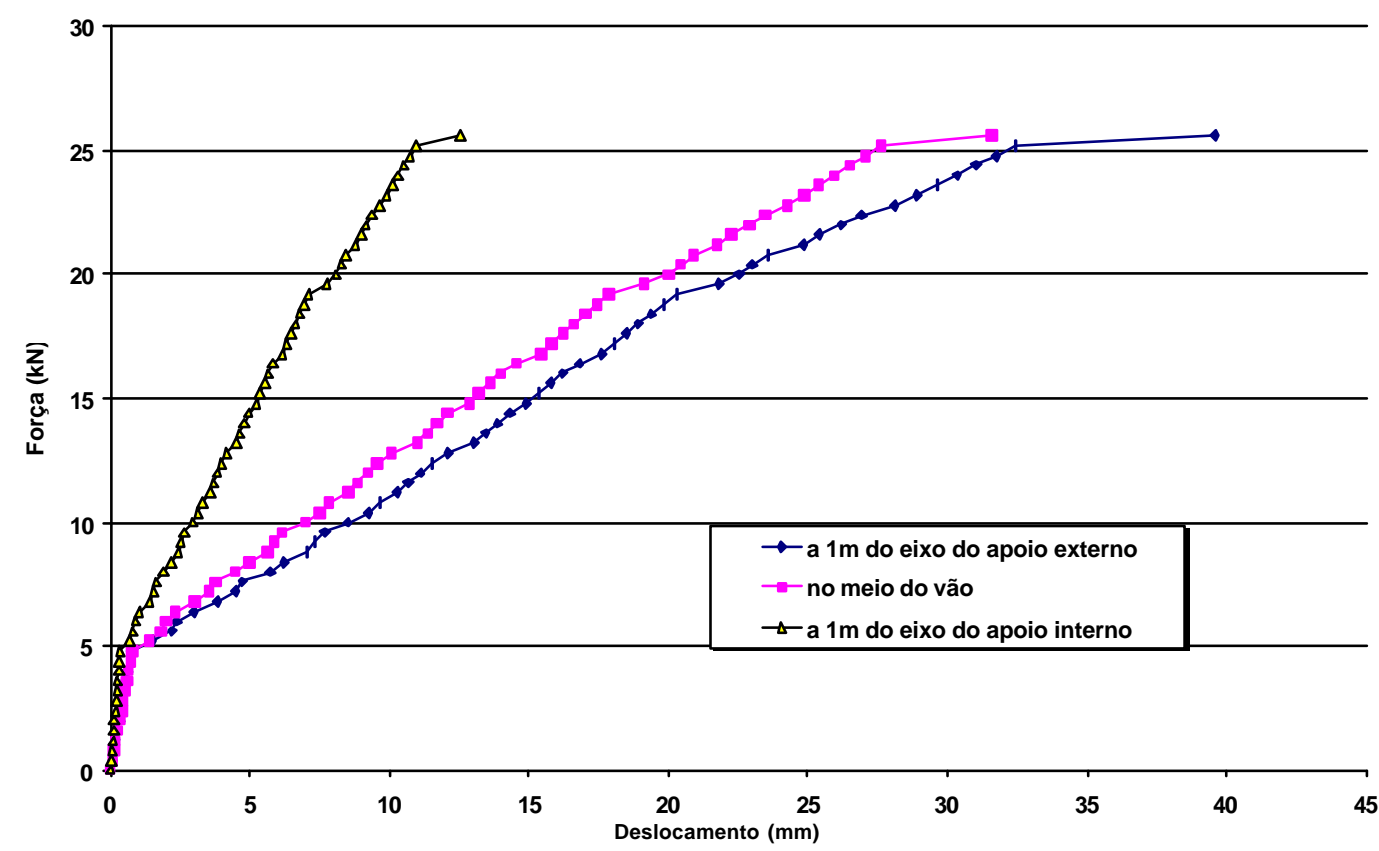

FIGURA 5.29 -Deslocamentos teóricos - modelo M0

Os deslocamentos teóricos ao longo do eixo longitudinal dos modelos M0 podem ser vistos nos diagramas das figuras 5.30. Neste modelo, o deslocamento máximo teórico (flecha teórica) nas etapas de carga ocorreu sempre na coordenada $130 \mathrm{~cm}$, conforme discussão feita no item 5.5.

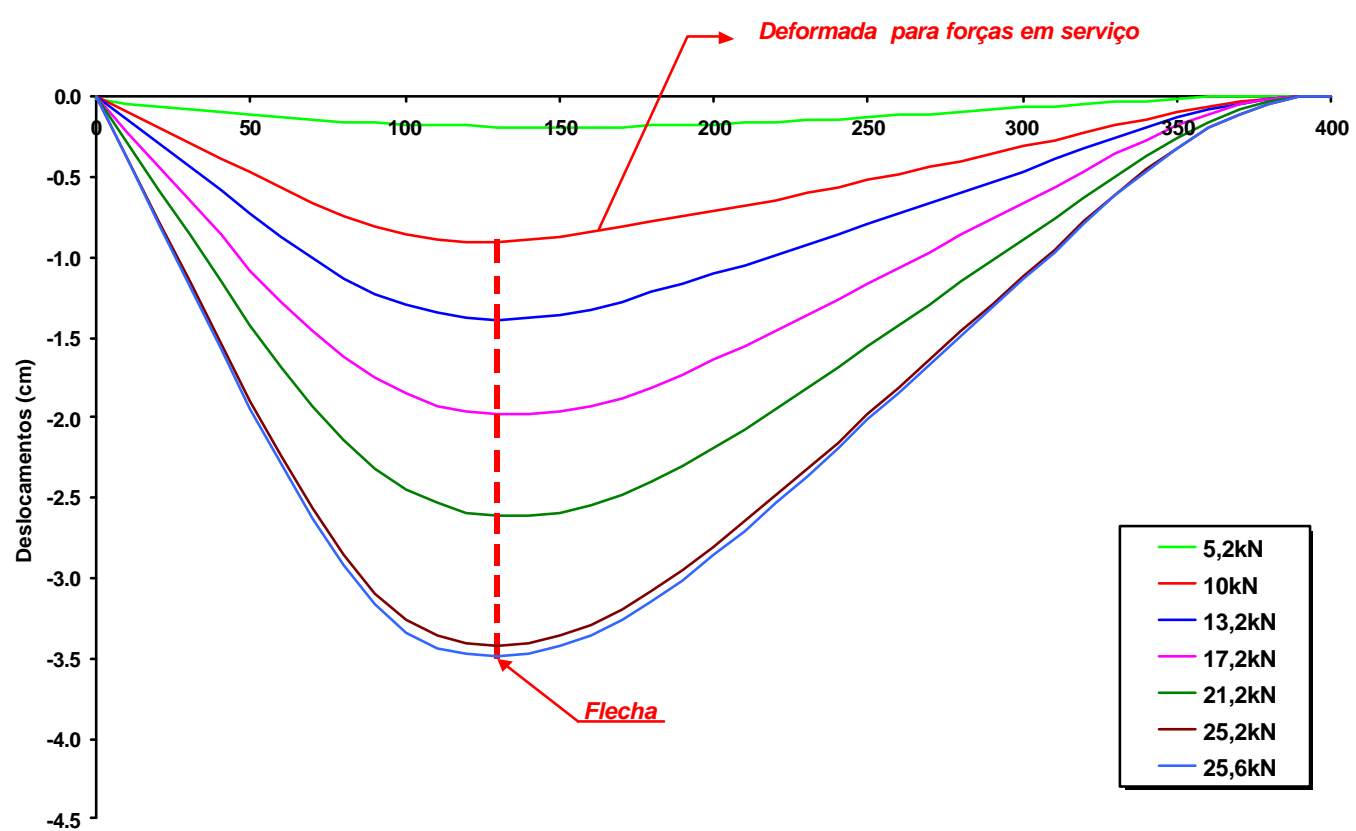

FIGURA 5.30 - Evolução dos deslocamentos - Análise teórica do modelo M0 
Na figura 5.31 é mostrado o diagrama força $x$ rigidez à flexão do modelo M0. Como havia previsto no item 5.5, as seções próximas ao apoio central são mais rígidas que as seções do meio do vão quando o elemento estrutural se encontra no estádio I. Com isto, nas etapas iniciais de carga os momentos fletores negativos não-lineares são maiores que os momentos fletores negativos obtidos na análise elástico-linear com rigidez constante. A fissuração nas seções do meio do vão e junto ao apoio central inicia na mesma etapa de carga e a partir daí a rigidez destas seções dependerão da taxa de armadura de flexão. No estádio II seções junto ao apoio central são mais rígidas que as seções do meio do vão uma vez que a taxa de armadura de flexão na região do apoio central é maior que a taxa de armadura de flexão existente no meio do vão (esta relação é de aproximadamente 2,4). Por este motivo não era de se esperar redistribuição dos momentos fletores negativos.

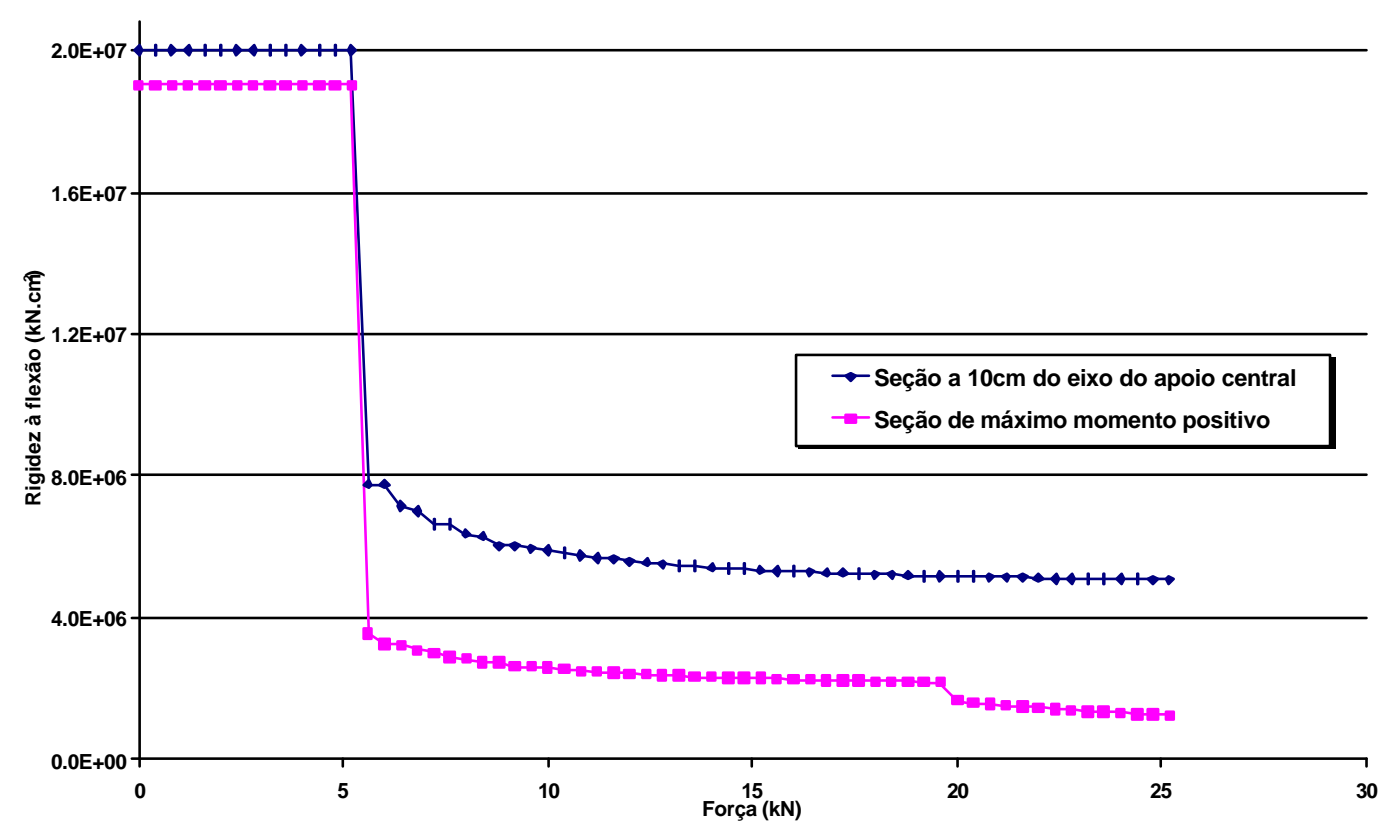

FIGURA 5.31- Rigidez à flexão $x$ força aplicada - análise teórica do modelo M0

Verificou-se na modelagem numérica do modelo M0 que não foi criada uma rótula plástica teórica nas seções próximas ao apoio central conforme o procedimento descrito no item 3.5 deste trabalho. Este modelo apresentou uma rótula plástica teórica no ponto de máximo momento fletor positivo, pois esta foi a primeira seção em que o momento fletor último foi atingido. Esta etapa de carga correspondeu na modelagem ao 
valor de força última, uma vez que os deslocamentos na seção da rótula plástica teórica começaram a crescer com grande velocidade (figura 5.29). 


\section{CONSIDERAÇÕES FINAIS E CONCLUSÕES}

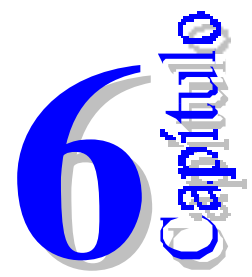

Procurou-se avaliar neste trabalho o comportamento dos momentos fletores negativos nos apoios de lajes formadas por elementos pré-moldados tipo nervuras com armação treliçada por meio do ensaio de faixas de lajes e de modelagens numéricas com a consideração da não-linearidade física do concreto armado.

Salienta-se aqui que as conclusões deste trabalho estão fundamentadas na análise teórico-experimental de 3 faixas de lajes com nervuras pré-moldadas tipo vigotas com armação treliçada, altura total de $12 \mathrm{~cm}$ e dois vãos de 4,0m. Portanto, para consolidar as conclusões deste trabalho, faz-se necessário a realização de novos ensaios, variando os parâmetros que definem as lajes (altura total, vãos, etc.). Com esta ressalva, percebe-se neste trabalho que:

- $\quad$ A análise não-linear em lajes nervuradas unidirecionais de concreto armado utilizando a relação momento $x$ curvatura do código modelo CEB-90 (1991) em conjunto com a técnica do carregamento incremental representa bem o comportamento real da estrutura.

- $\quad$ O modelo de Darmstadt-Leipzig apresentado no CEB (1998) representa bem a capacidade de rotação das rótulas plásticas em lajes nervuradas unidirecionais. Atenta-se que, ao se utilizar este modelo na análise teórica nãolinear, as rotações plásticas praticamente são iguais àquelas encontradas em 
ensaio, fato este que pode não ser verificado quando as dimensões e o carregamento das lajes são alterados.

- $\quad$ As faixas de lajes nervuradas com armação treliçada dimensionadas a partir da análise elástico-linear com rigidez constante ou com redistribuição de $15 \%$ dos momentos fletores negativos sempre apresentam no seu histórico de cargas momentos fletores negativos maiores àqueles obtidos com a análise elástico-linear com rigidez constante.

- Mesmo que o dimensionamento em lajes nervuradas seja realizado com uma redistribuição de $15 \%$ dos momentos fletores negativos, não é sempre que se verifica redistribuição de momentos fletores no comportamento real da estrutura.

- $\quad$ O procedimento usualmente adotado por projetistas na consideração da redistribuição dos momentos fletores negativos em limitar o momento fletor negativo ao valor do momento resistente da seção calculado com a linha neutra no limite dos domínios 3 e 4 não garante que em qualquer situação existirá redistribuição de esforços.

- As lajes nervuradas unidirecionais contínuas dimensionadas com elevados graus de redistribuição de momentos fletores negativos $(\eta)$ apresentam no estado limite último boa capacidade de redistribuição de esforços, decorrentes da capacidade das seções do apoio interno desenvolverem rotações plásticas.

- Independente do grau de redistribuição de momentos fletores negativos adotado no dimensionamento, todas as faixas de lajes nervuradas analisadas neste trabalho apresentaram valores de deslocamentos máximos (flechas) próximos entre si para as situações em serviço.

- De acordo com os estudos realizados neste trabalho, a relação entre as rigidezes no estádio II das seções onde atuam os máximos momentos fletores positivos e negativos pode ser utilizada como parâmetro na estimativa se ocorrerá, ou não, redistribuição de esforços.

- $\quad$ Com relação ao estado limite de utilização no que diz respeito a abertura de fissuras, quanto maior o grau de redistribuição de momentos fletores negativos 
utilizado no dimensionamento, obtém-se fissuras sobre os apoios interiores distribuídas em trechos cada vez menores porém com aberturas maiores. As aberturas destas fissuras podem ser controladas utilizando-se como armadura negativa barras com diâmetros e espaçamentos menores ou barras com nervuras. Atenção especial deve ser dada ao se utilizar barras com nervuras como armadura negativa, pois, embora estas melhorem o comportamento com relação à abertura e distribuição das fissuras, elas podem diminuir a capacidade de rotação das rótulas plásticas nos apoios internos conforme discutido no CEB (1998) e apresentado no item 3.4 deste trabalho.

- A laje dimensionada com tramos simplesmente apoiado apresenta o maior consumo de armadura de flexão (tabela 4.1) decorrente da parcela de armadura construtiva presente nos apoios. Nos demais modelos analisados, o consumo de armadura de flexão praticamente não é alterado pelo grau de redistribuição dos momentos fletores negativos adotado no dimensionamento.

- Quanto menor o grau de redistribuição dos momentos fletores negativos, maior será a responsabilidade da armadura negativa na segurança global da estrutural. Com isto, usa-se redistribuição dos momentos fletores negativos de modo a reduzir a responsabilidade da armadura negativa na segurança global da estrutura, uma vez que o posicionamento desta armadura precisa de maiores cuidados quando comparados com a armadura positiva. Além disso, existem as vantagens apresentadas no item 2.4 deste trabalho em se projetar utilizando momentos fletores redistribuídos.

A partir das reflexões acima, a situação nas quais as lajes contínuas com nervuras pré-moldadas apresentariam o melhor comportamento na sua construção, nos estados limites últimos e de utilização corresponderia àquela na qual fosse considerado no dimensionamento um grau de redistribuição dos momentos fletores negativos compreendido entre os limites de $15 \%$ e $40 \%$. Entretanto, é importante lembrar a NBR6118 (1978), quando trata do dimensionamento com redistribuição dos momentos fletores em vigas e a norma espanhola EF-96 (1997) quando trata do dimensionamento com os 
momentos fletores redistribuídos em lajes com nervuras pré-moldadas, não permitem graus de redistribuição dos momentos fletores negativos superiores a $15 \%$.

Ressalta-se aqui que as conclusões deste trabalho estão fundamentadas nas análises teórico-experimental de três faixas de lajes com nervuras pré-moldadas tipo vigotas com armação treliçada. Portanto, sugere-se aqui a realização de novos ensaios e modelagens numéricas em lajes nervuradas onde serão variados as dimensões das lajes, o número de vãos e os graus de redistribuição dos momentos fletores no dimensionamento. Com isto, as conclusões descritas acima poderiam ser consolidadas para as mais diversas situações.

Ainda como complementação deste trabalho de pesquisa, sugerem-se ensaios com cargas de longa duração em faixas de lajes contínuas com nervuras pré-moldadas tipo armação treliçada de modo a analisar o efeito da fluência nos deslocamentos e na redistribuição de esforços.

Sugere-se ainda a análise teórico-experimental em painéis de lajes bidirecionais com apoios nas extremidades e um apoio central de modo a avaliar a capacidade de rotação das rótulas plásticas em estruturas planas sujeitas ao efeito conjunto dos esforços de flexão, cisalhamento e torção. 


\section{BIBLIOGRAFIA}

\section{Referências bibliográficas}

ASSOCIAÇÃO BRASILEIRA DE NORMAS TÉCNICAS. (1978). NBR 6118 -

Projeto e execução de obras de concreto armado. Rio de Janeiro.

ASSOCIAÇÃO BRASILEIRA DE NORMAS TÉCNICAS. (1984). NBR 8681 Ações e segurança nas estruturas. Rio de Janeiro.

ASSOCIAÇÃO BRASILEIRA DE NORMAS TÉCNICAS. (1985). NBR 7480 -

Barras e fios de aço destinados a armaduras para concreto armado. Rio de Janeiro.

ASSOCIAÇÃO BRASILEIRA DE NORMAS TÉCNICAS. (1989). NBR 7197 Projeto de estruturas em concreto protendido. Rio de Janeiro.

BORGES, J. (1997). Critérios de projeto de lajes nervuradas com vigotas prémoldadas. São Paulo. Dissertação (Mestrado) - Escola Politécnica da Universidade de São Paulo.

BUCHAIM, R.; STUCCHI, F. R. (2000). A capacidade de rotação plástica em elementos unidimensionais de concreto armado. In: IV SIMPÓSIO EPUSP SOBRE ESTRUTURAS DE CONCRETO. São Paulo, 2000. EPUSP - USP.

CARVALHO, R.C. (1994). Análise não-linear de pavimentos de concreto através da analogia de grelha. São Carlos. 207p. Tese (Doutorado) - Escola de Engenharia de São Carlos, Universidade de São Paulo. 
CALAVERA, J. et al. (1988). Estudio experimental sobre el comportamiento en servicio y agotamiento por flexion de forjados unidireccionales de hormigon armado. Madrid, España - Escuela tecnica superior de ingenieros de Caminos.

CAMARA, J.M. (1988). Comportamento em serviço de estruturas de betão armado e pré-esforçado. Tese (Doutorado) - Escola de Engenharia, Universidade Técnica de Lisboa.

COMITE EURO-INTERNATIONAL DU BETON (1991). CEB-FIP model code 1990. Bulletin d'Information, n. 203.

COMITE EURO-INTERNATIONAL DU BETON (1998). Ductilility of reinforced concrete strutures. Bulletin d'Information, n. 242.

DI PIETRO, J. E. (1993). Projeto, execução e produção de lajes com vigotes prémoldados de concreto. Florianópolis. 99p. Dissertação (Mestrado) - Universidade Federal de Santa Catarina.

DINIZ, H. (1988). Lajes com armação em treliça. 2 ed. São Paulo, Vieira Campos.

DROPPA JÚNIOR, A. (1999). Análise estrutural de lajes formadas por elementos pré-moldados tipo vigota com armação treliçada. São Carlos. 177p.. Dissertação (Mestrado) - Escola de Engenharia de São Carlos, Universidade de São Paulo.

EL DEBS, M. K. (2000). Concreto pré-moldado: Fundamentos e Aplicações. São Carlos. Projeto REENGE. EESC - USP.

ESPANHA. Ministério de Fomento (1997). EF-96 - Instruccion para el proyecto y la ejecucion de forjados unidireccionales de hormigon armado o protensado.

FRANCA, A.B.; FUSCO, P.B (2000). As lajes nervuradas na moderna construção de edifícios. São Paulo, AFALA/ABRAPEX.

LEONHARDT, F; MONNIG, E.(1982). Construções de concreto: verificação da capacidade de utilização. Vol. $42^{\underline{a}}$ ed. Rio de Janeiro, Editora Interciência.

LIMA, J.C.O. (1993). Sistema treliçado global. 4.ed. Campinas, Mediterrânea. (Boletim técnico).

MUNIZ. C. E. (1991). Mais competitivas: lajes treliçadas. Revista IBRACON, v.1, n.1, p.19-21, julho, agosto.

PEREIRA, V. (2000). Manual de projeto de lajes pré-moldadas treliçadas. São Paulo, Associação dos fabricantes de lajes de São Paulo. 


\section{Bibliografia complementar}

ASSOCIAÇÃO BRASILEIRA DE NORMAS TÉCNICAS. (1980). NBR 6120 Cargas para o cálculo de estruturas de edificações. Rio de Janeiro.

BARBIRATO, C. B. (1997). Contribuições à análise de pavimentos de edifícios em laje nervurada. São Carlos. 138p. Dissertação (Mestrado) - Escola de Engenharia de São Carlos, Universidade de São Paulo.

BARBOZA, A.S.R. (1992). Contribuição à análise estrutural de sistemas lajes-vigas de concreto armado mediante analogia de grelha. São Carlos. 129p. Dissertação (Mestrado) - Escola de Engenharia de São Carlos, Universidade de São Paulo.

BOCCHI JÚNIOR., C.F. (1995). Lajes nervuradas de concreto armado: projeto e execução. São Carlos. 183p. Dissertação (Mestrado), Escola de Engenharia de São Carlos, Universidade de São Paulo.

CALAVERA, J. et al. (1988). Comportamiento hasta rotura de forjados isostaticos e hiperestaticos de viguetas armadas. Madrid, España - Escuela tecnica superior de ingenieros de Caminos.

CALAVERA, J. et al. (1988). Estudio teorico y experimental de flechas instataneas y diferidas en forjados unidireccionales de hormigon armado. Madrid, España Escuela tecnica superior de ingenieros de Caminos.

CALAVERA, J. et al. (1988). Criterios generales para la comprobacion del estado limite de servicio de deformaciones en forjados de viguetas de hormigon armado. Madrid, España - Escuela tecnica superior de ingenieros de Caminos.

ESPANHA. Ministério de Fomento (1988). EF-88 - Instruccion para el proyecto y la ejecucion de forjados unidireccionales de hormigon armado o protensado.

GELFI, P.; GIURIANI E. (1986). Effetti della fessurazione sugli appoggi ed in campata nelle travi continue de concreto armato. Prefabbricazione - Roma, ex 22 n $11 / 12$

GONZALEZ, R. L. (1997). Análise de lajes pela teoria das charneiras plásticas e comparação de custos entre lajes maciças e lajes treliçadas. São Carlos. 114p. Dissertação (Mestrado) - Escola de Engenharia de São Carlos, Universidade de São Paulo. 
KODUR, V.; CAMPBELL K (1996) . Evaluation of moment redistribution in a twospan continuous prestressed concrete beam. ACI Structural Journal, v.93, n.6, p.721-728, novembro, dezembro.

KISS, P. (1998). Lajes do futuro. Revista Construção, n. 2616, p.16-19, março.

LEONHARDT, F.; MONNIG, E. (1982) Construções de concreto: princípios básicos do dimensionamento de estruturas de concreto armado. Vol. $12^{\underline{a}}$ ed. Rio de Janeiro, Editora Interciência.

MERLIN A. J. (1999). Lajes pré-moldadas de concreto: a consideração da plastificação nos valores dos momentos negativos em elementos hiperestáticos e seus efeitos no dimensionamento do pavimento. Trabalho de iniciação científica. Universidade Federal de São Carlos.

SKOGMAN B. et al. (1989). Ductility of reinforced and prestressed concrete flexural member. PCI Headquarters, agosto

SOUZA, V.C.M, et al. (1983) Lajes em concreto armado e protendido. Niterói, EDDUFF. Universidade Federal Fluminense Niterói. 


\section{APÊNDICE}

Apresentam-se neste apêndice os diagramas experimentais de força $x$ deslocamentos e força $x$ deformações nos pontos instrumentados dos modelos M15, M40 e Mac.

Os diagramas de força $x$ deslocamentos nos pontos instrumentados são mostrados nas figuras A.1 a A.15, conforme convenção apresentada na figura 4.24 do capítulo 4.

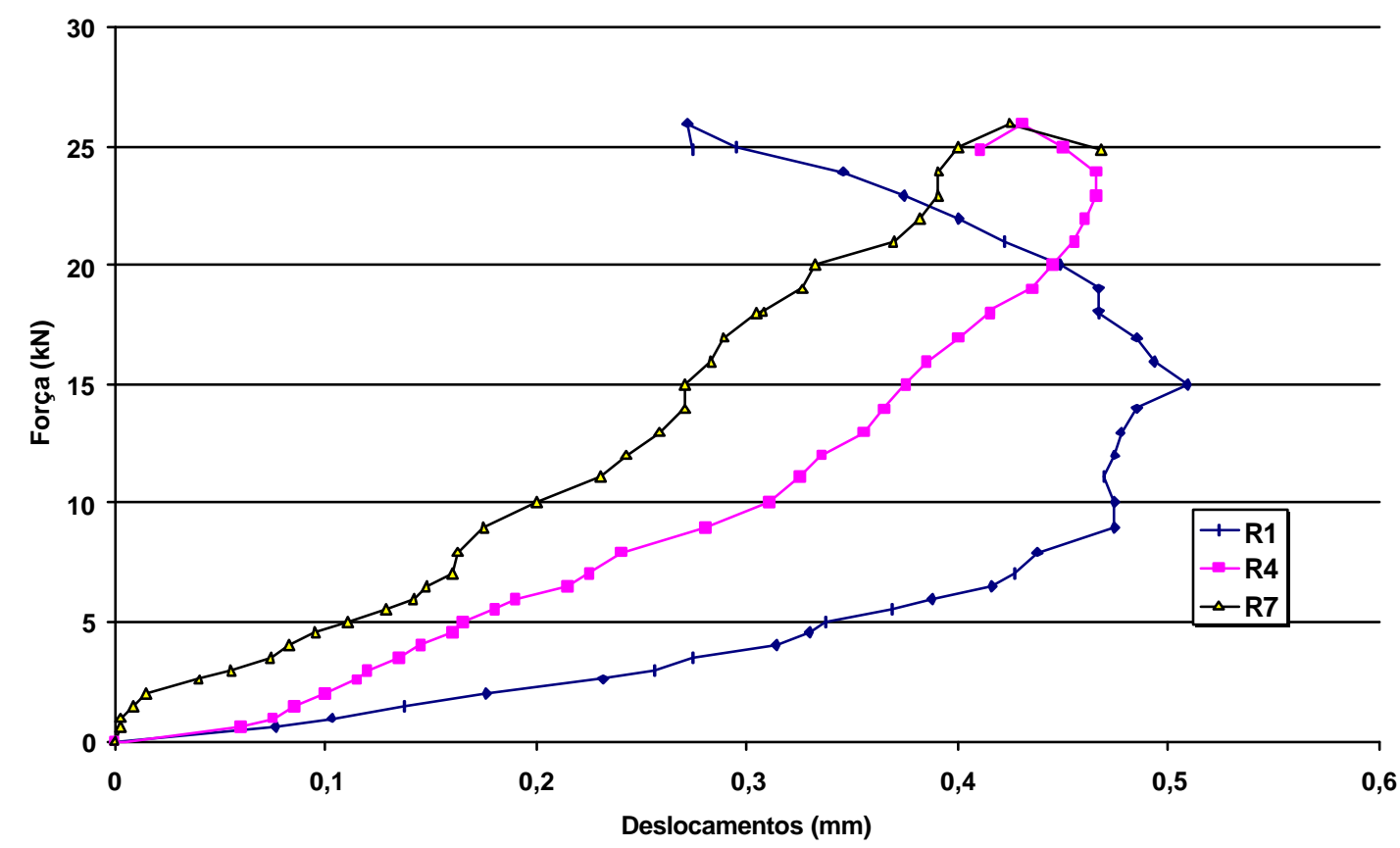

FIGURA A.1 - Deslocamentos dos apoios - M15 


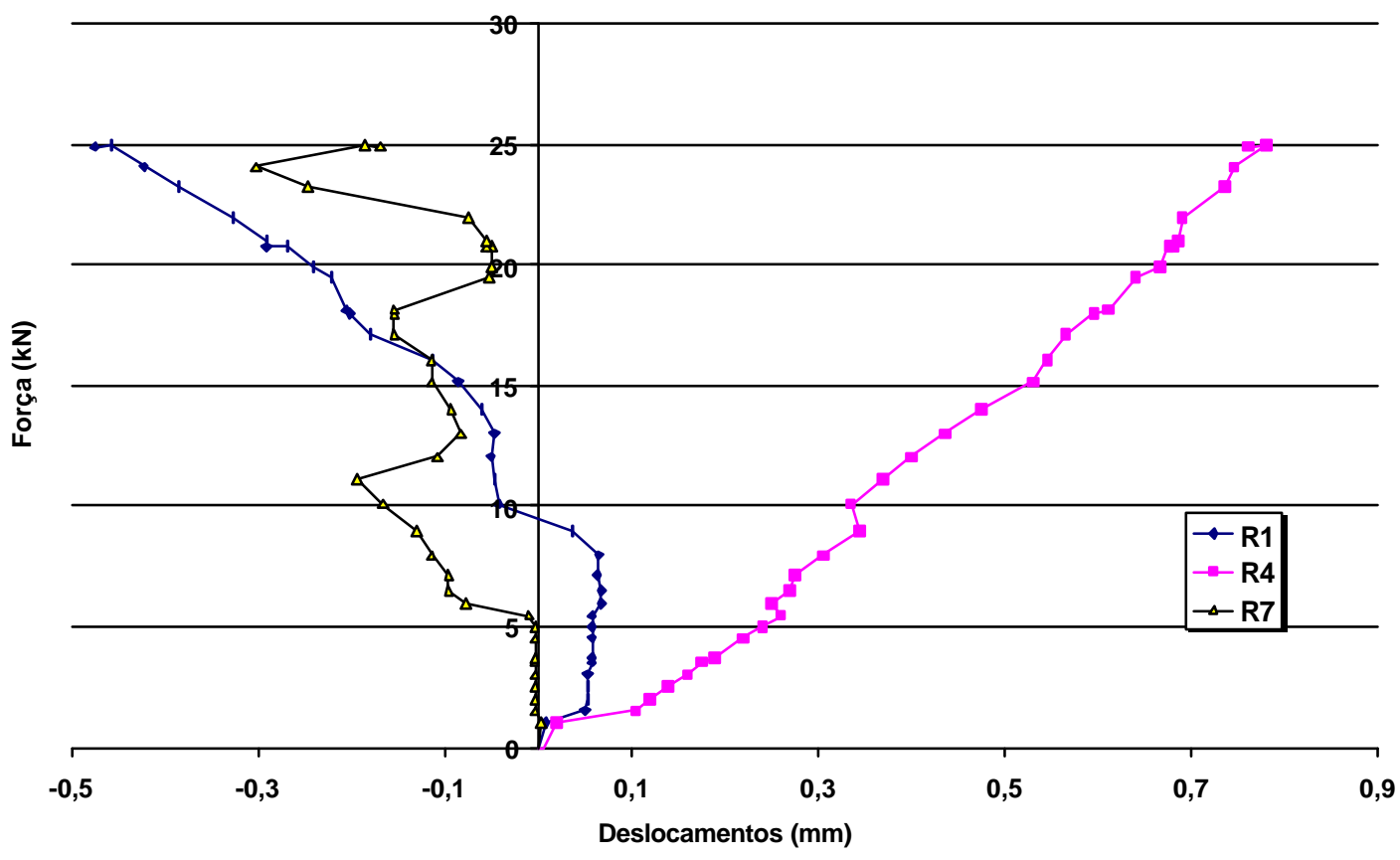

FIGURA A.2 - Deslocamentos dos apoios - M40

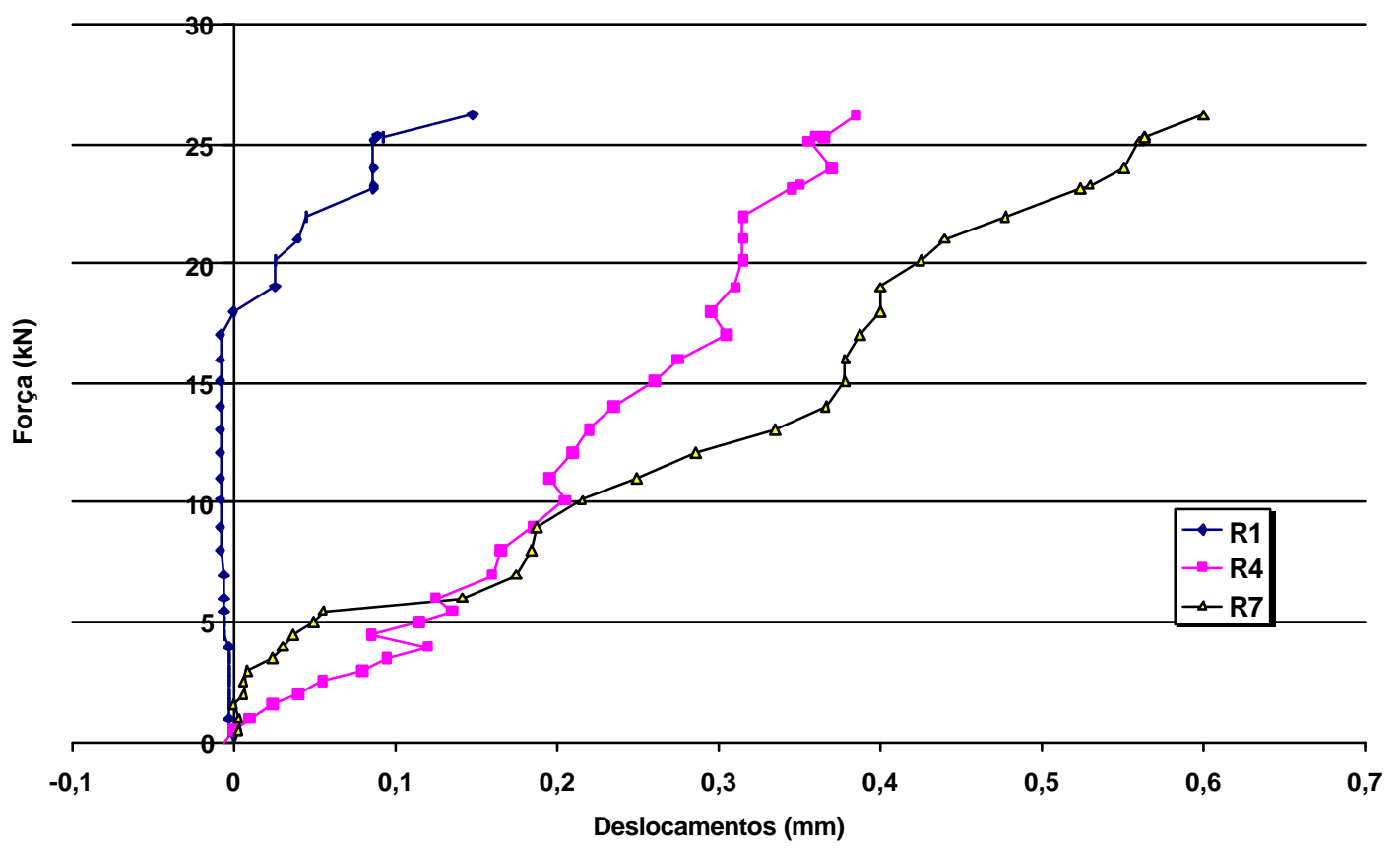

FIGURA A.3 - Deslocamentos dos apoios - Mac 


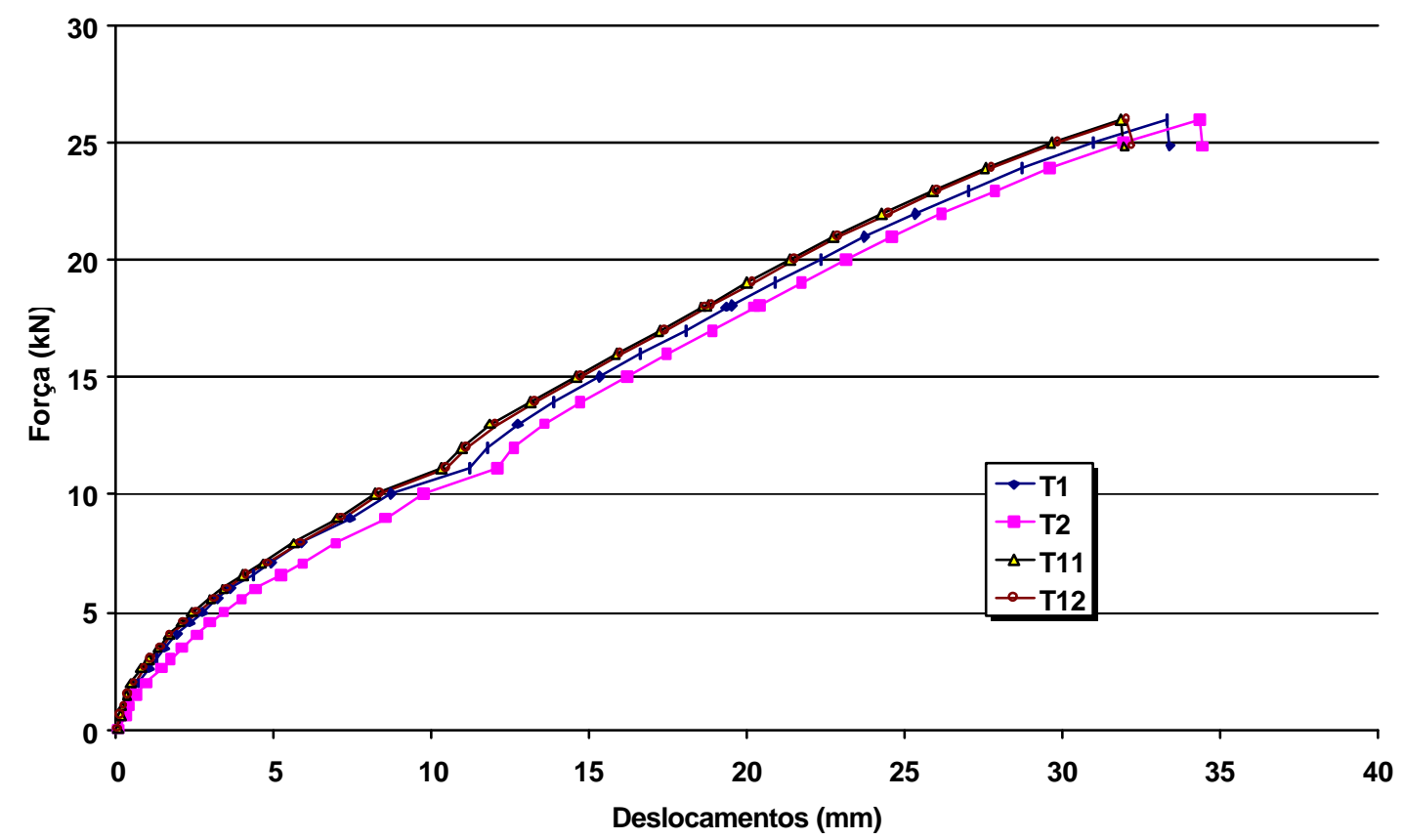

FIGURA A.4 - Deslocamentos a 1m dos eixos dos apoios externos - M15

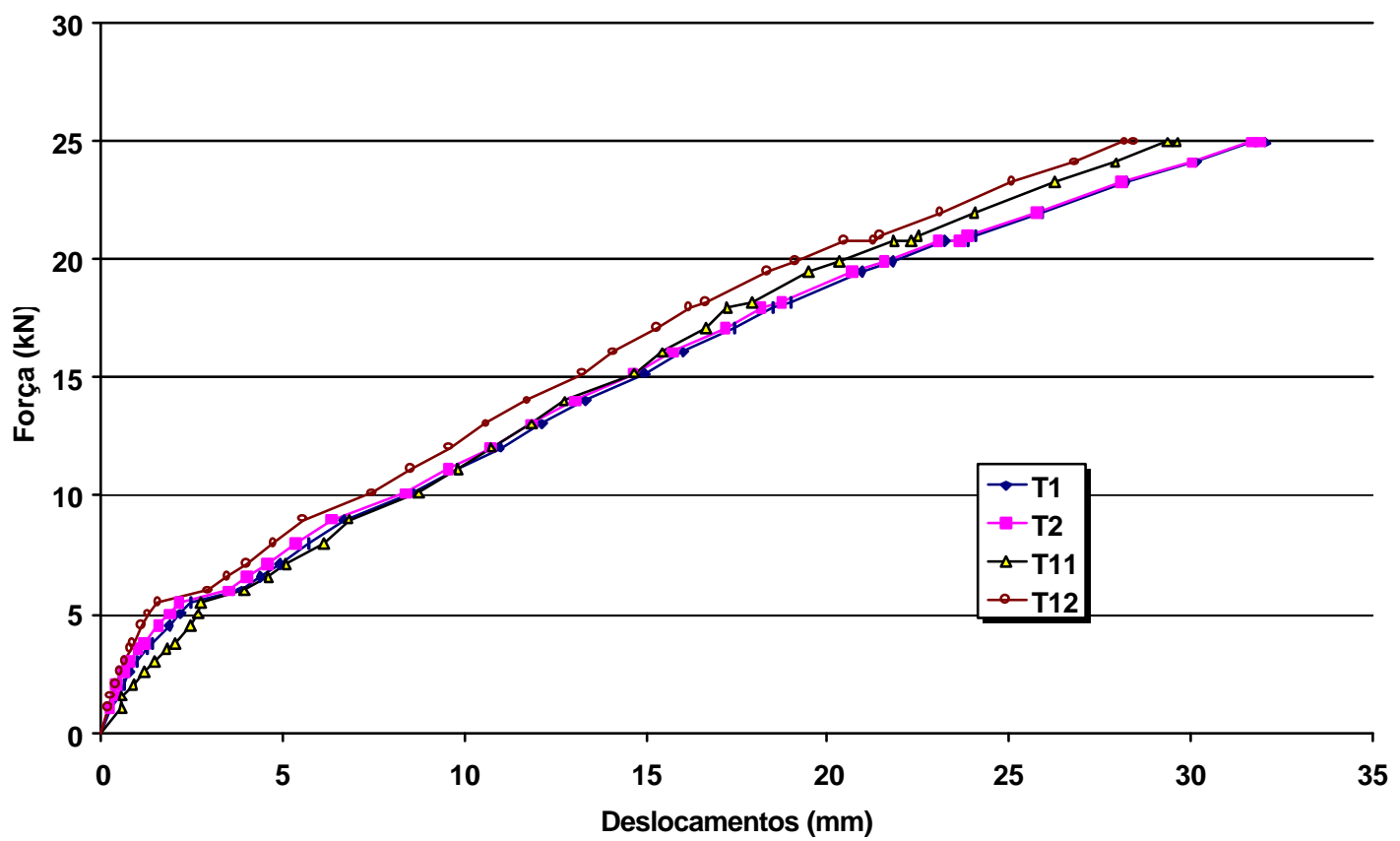

FIGURA A.5 - Deslocamentos a 1m dos eixos dos apoios externos - M40 


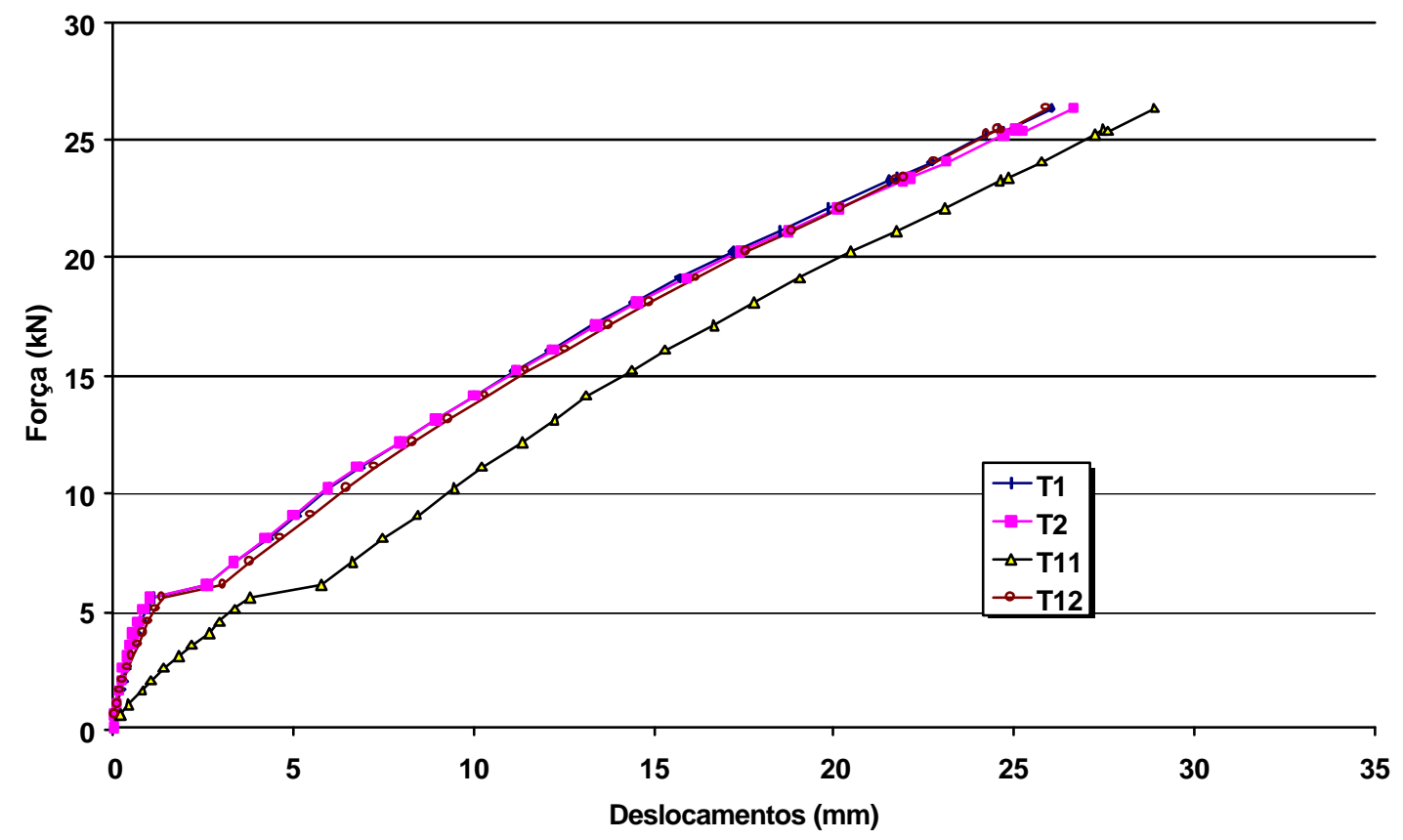

FIGURA A.6 - Deslocamentos a 1m dos eixos dos apoios externos - Mac

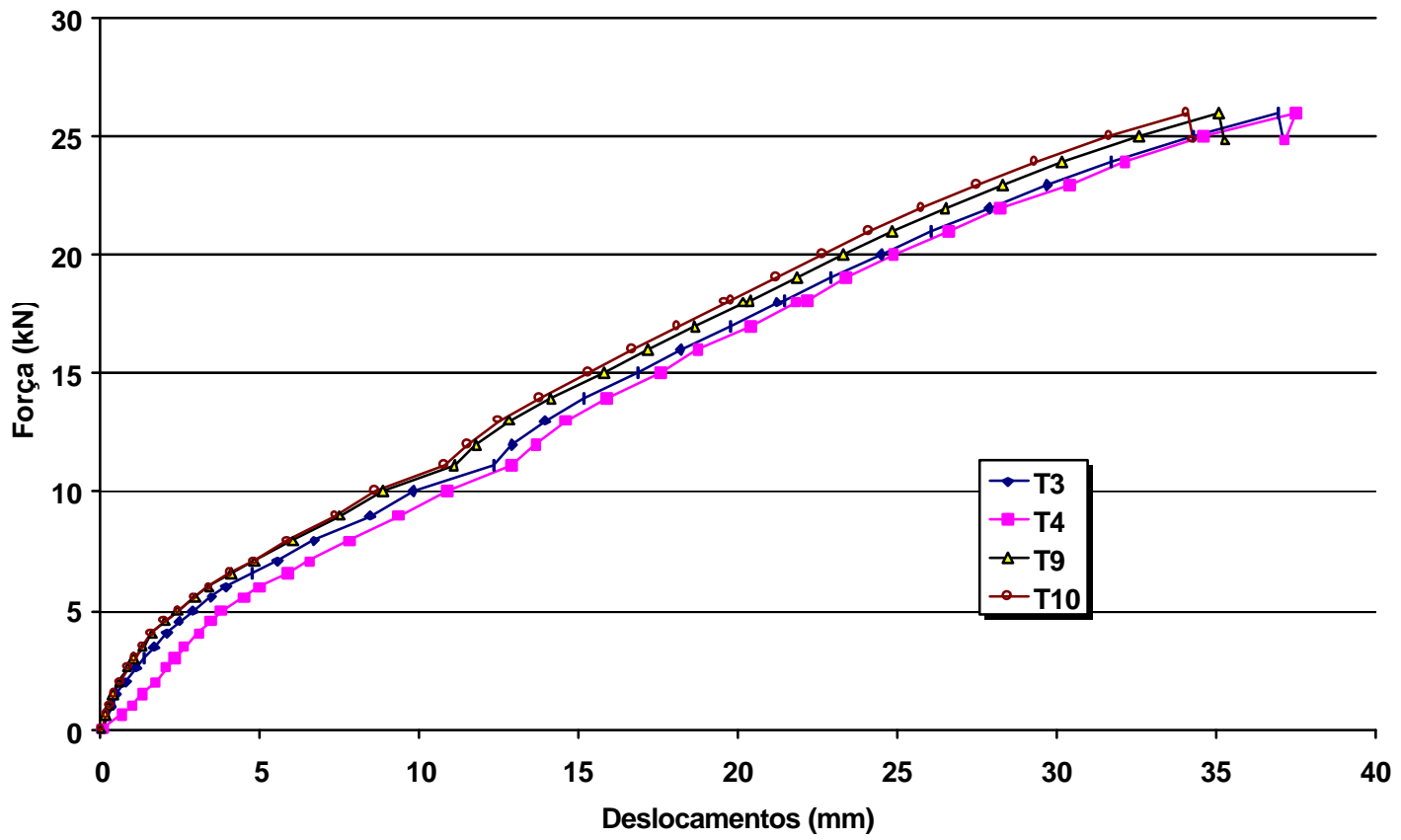

FIGURA A.7 - Deslocamentos no meio do vão - M15 


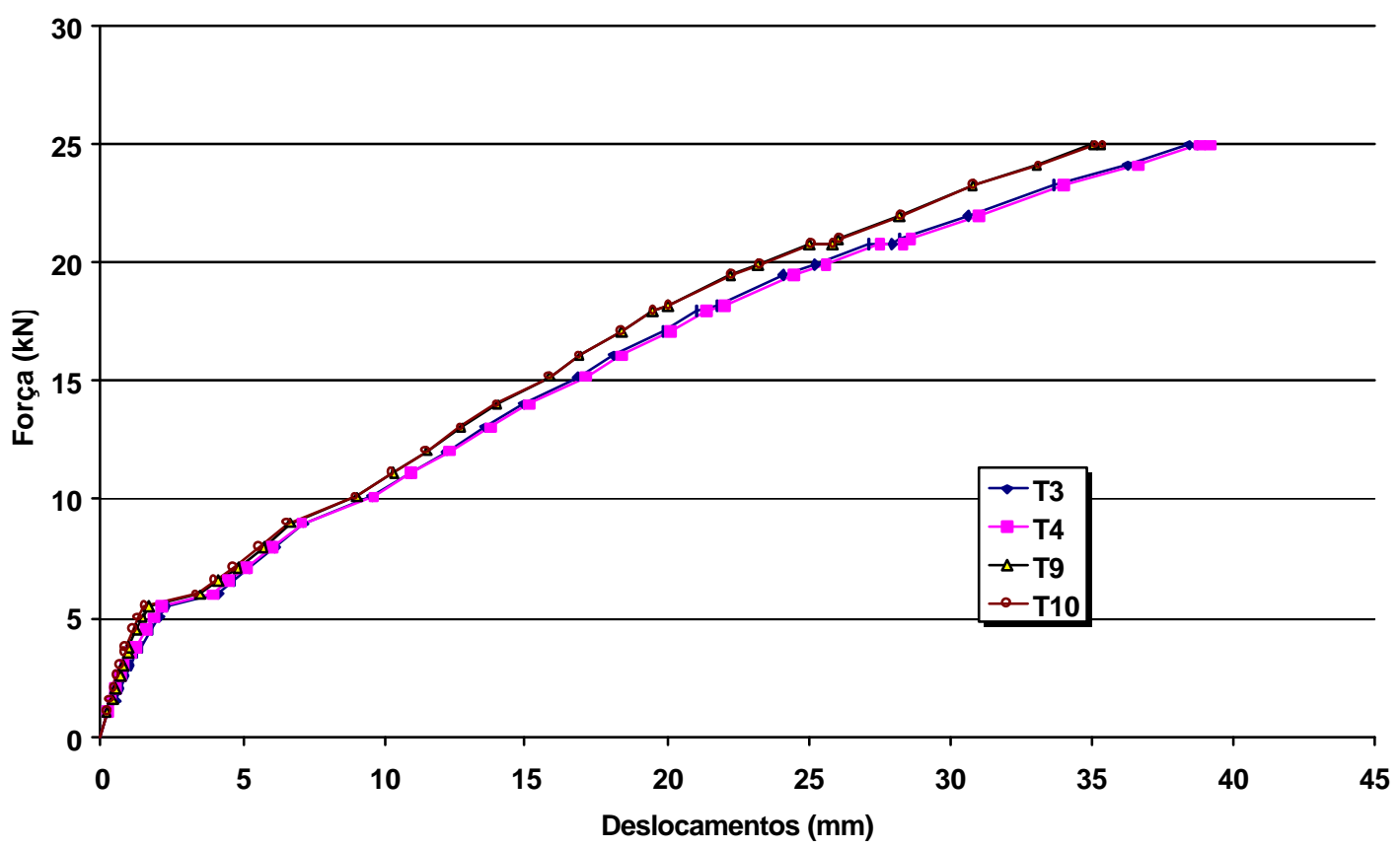

FIGURA A.8 - Deslocamentos no meio do vão - M40

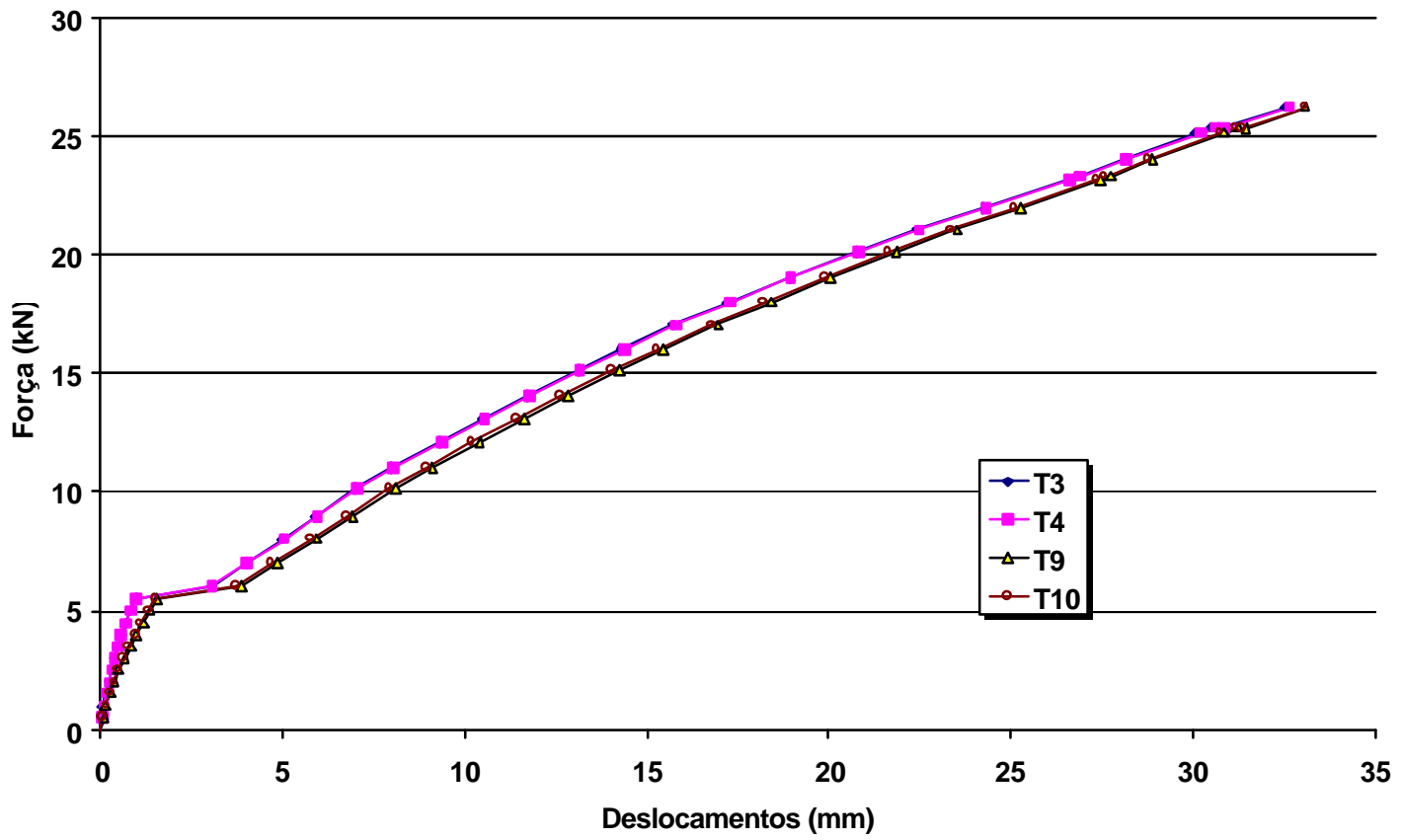

FIGURA A.9 - Deslocamentos no meio do vão - Mac 


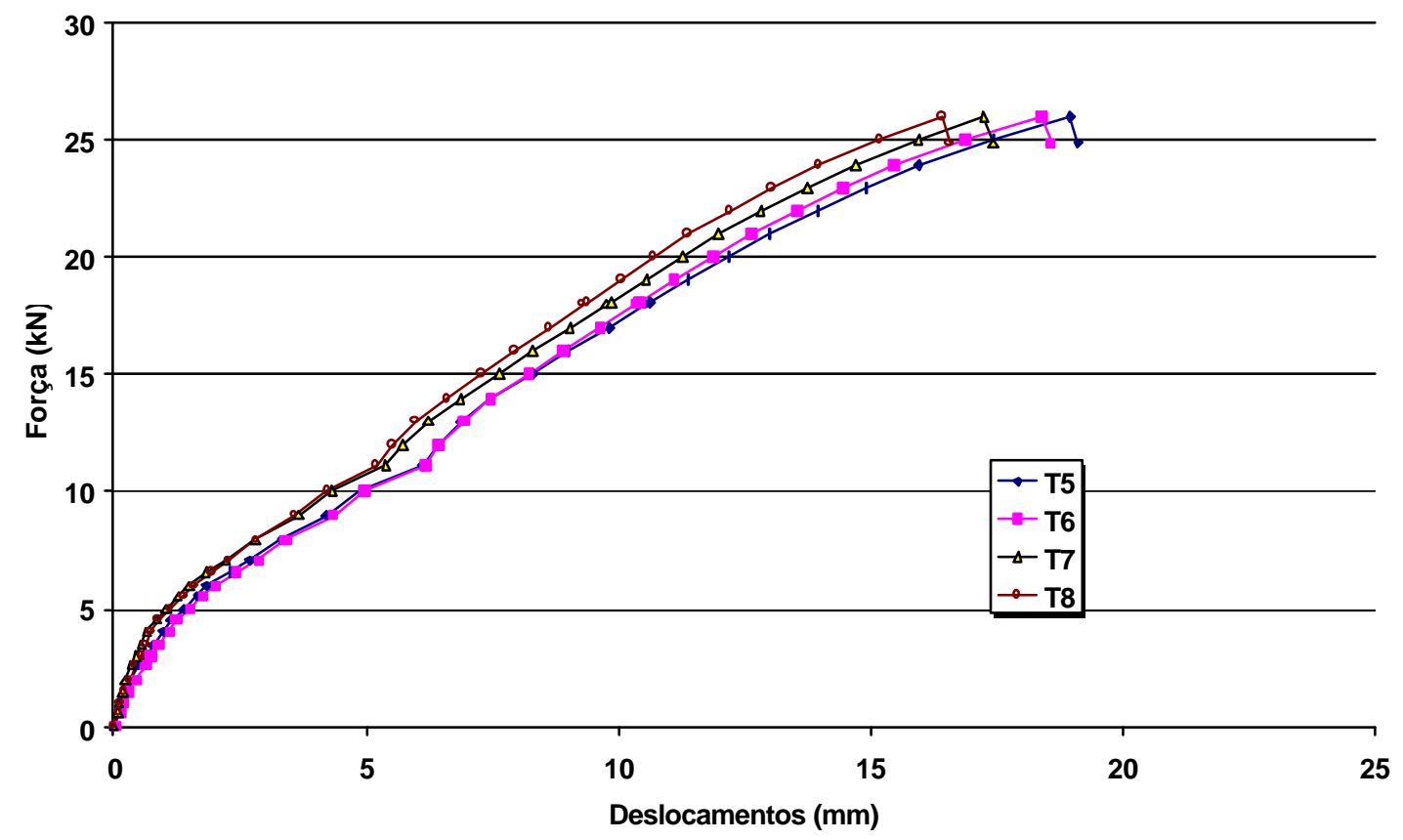

FIGURA A.10 - Deslocamentos a 1m do eixo do apoio interno - M15

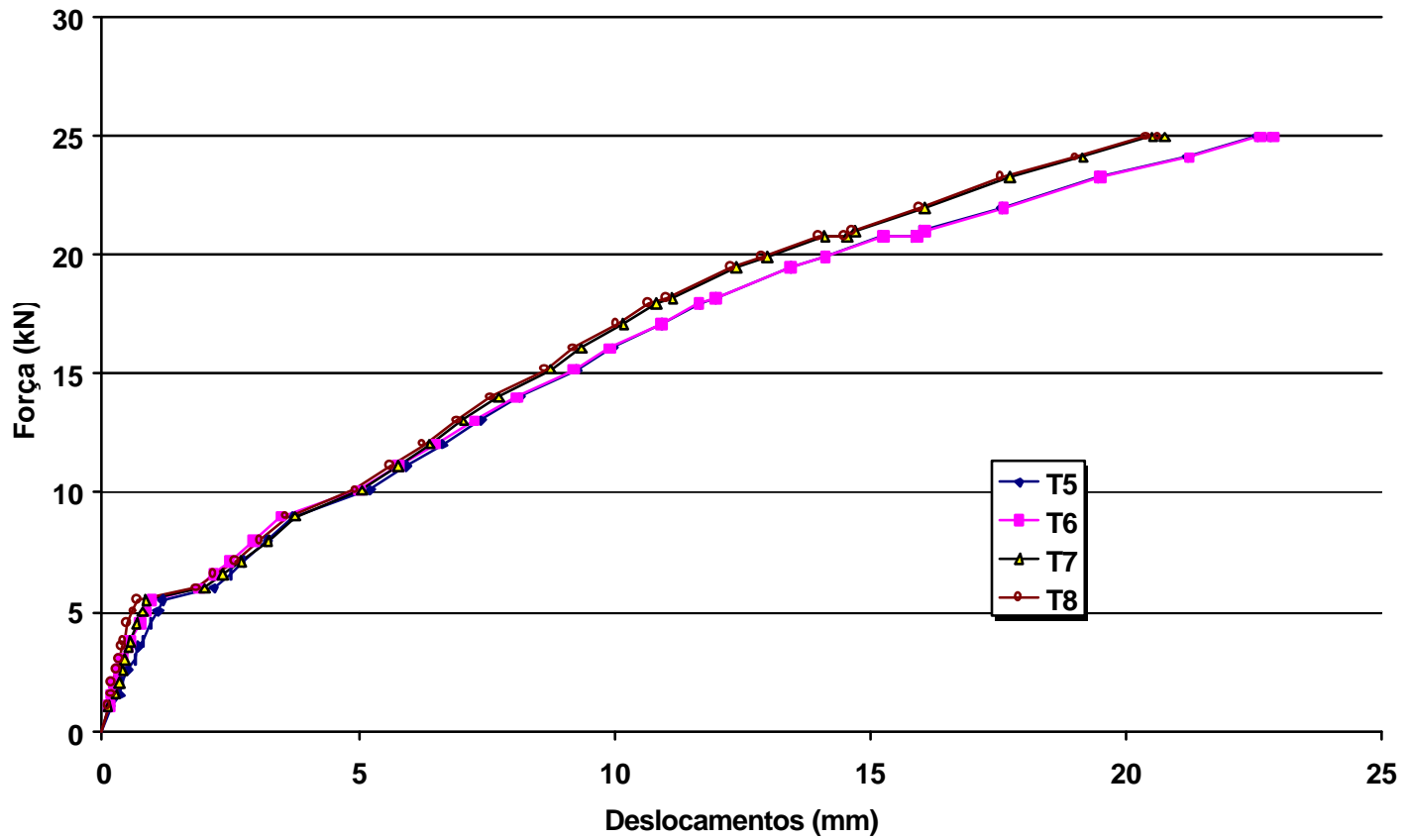

FIGURA A.11 - Deslocamentos a 1m do eixo do apoio interno - M40 


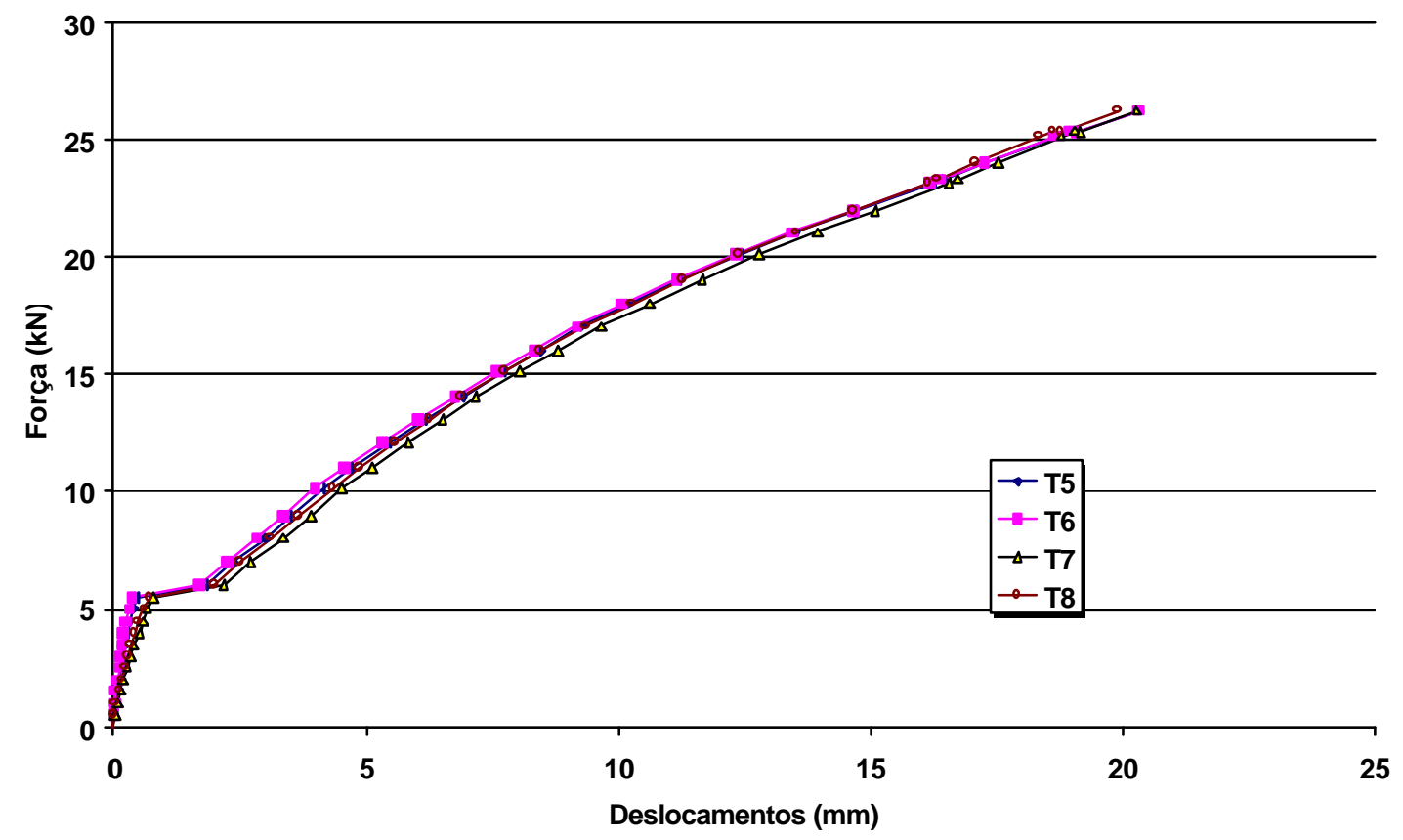

FIGURA A.12 - Deslocamentos a 1m do eixo do apoio interno - Mac

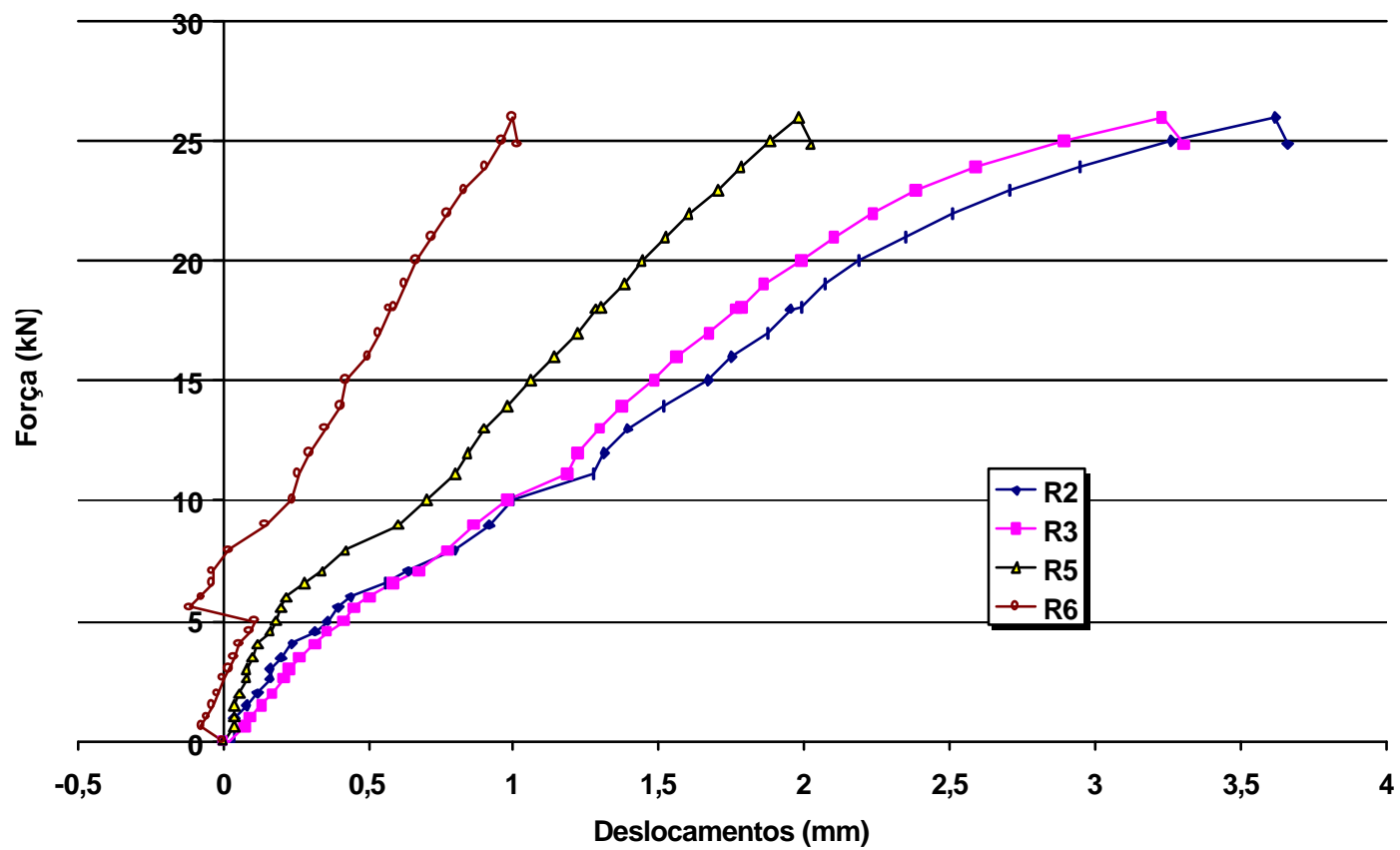

FIGURA A.13 - Deslocamentos a 25cm do eixo do apoio interno - M15 


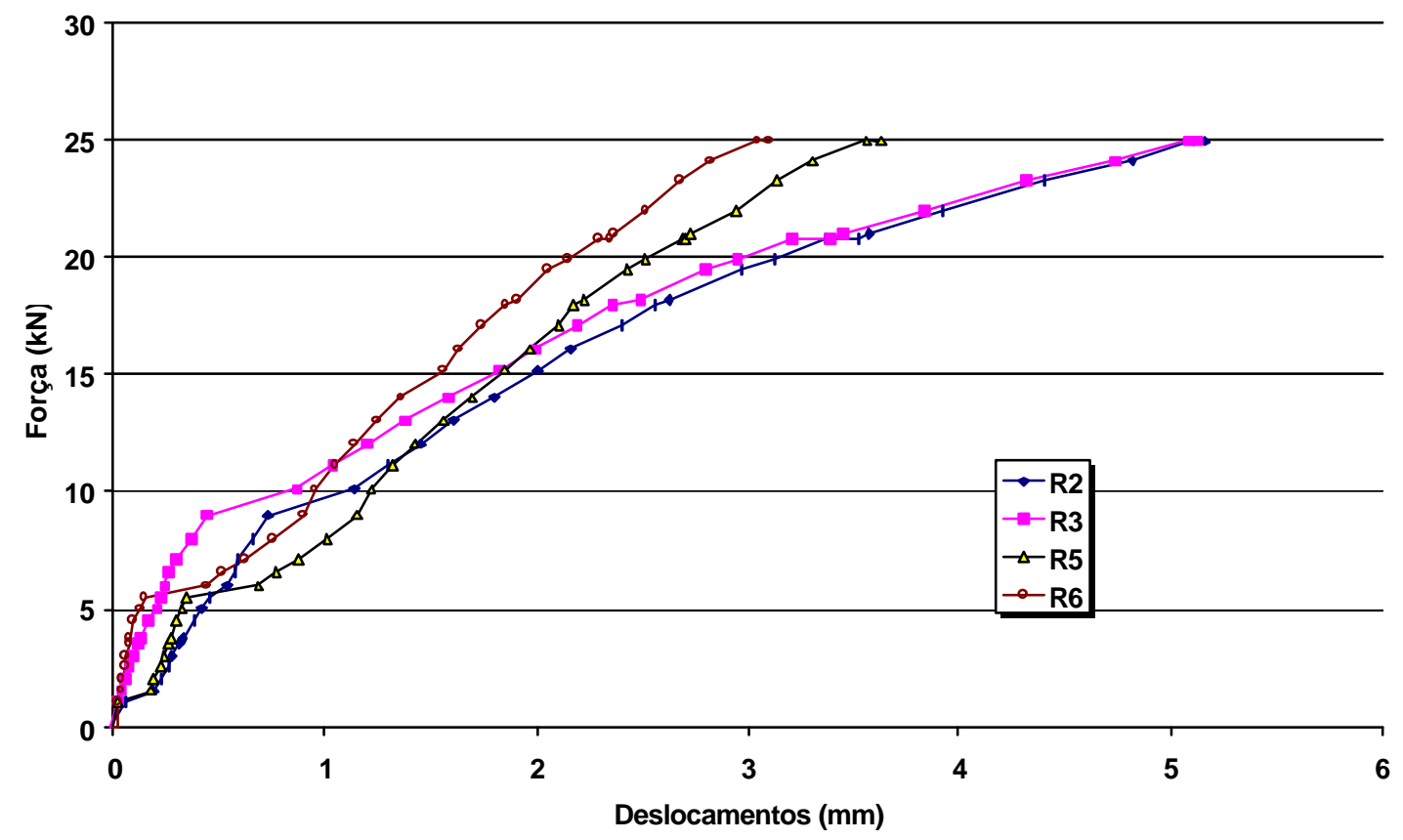

FIGURA A.14 - Deslocamentos a 25cm do eixo do apoio interno - M40

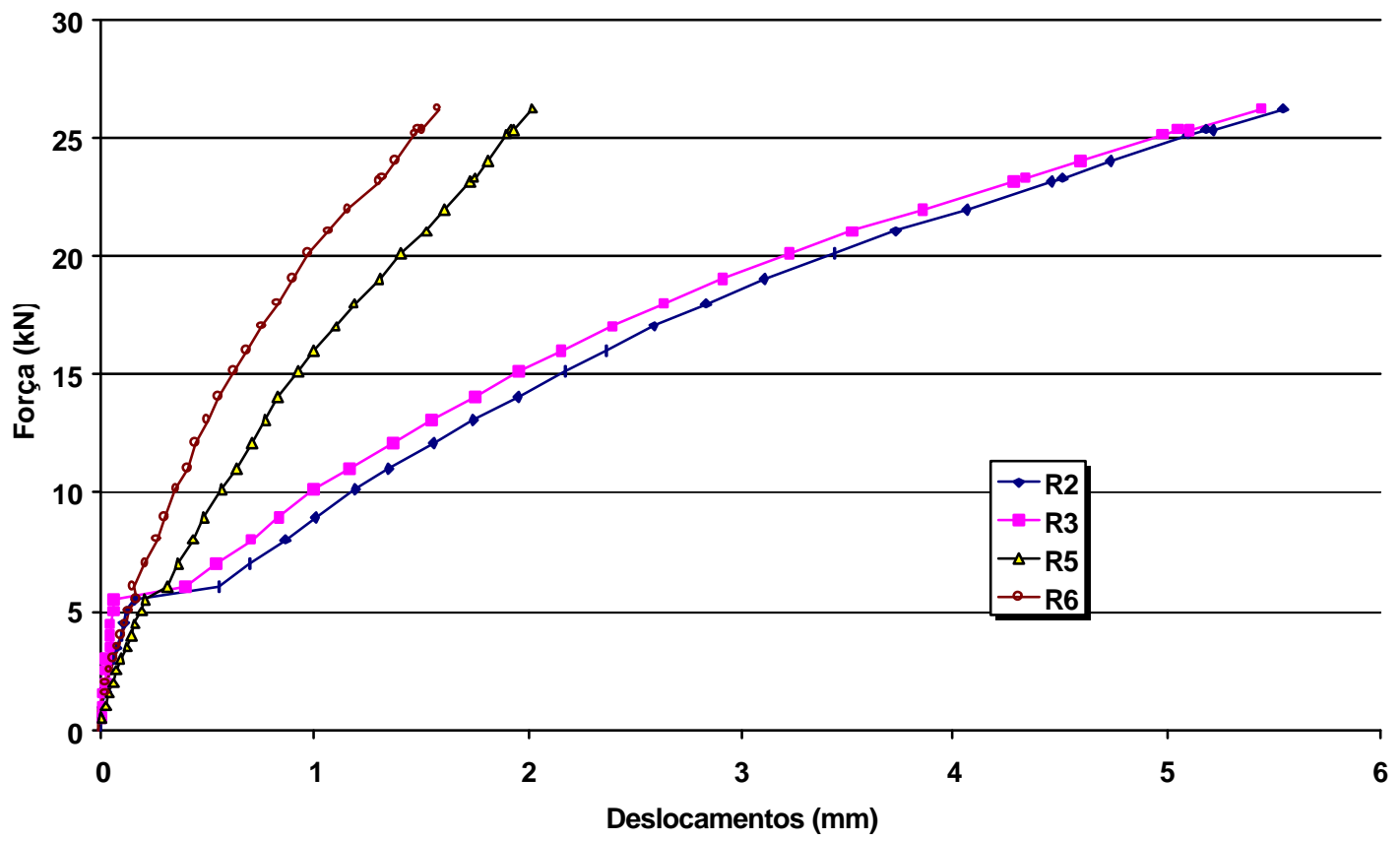

FIGURA A.15 - Deslocamentos a $25 \mathrm{~cm}$ do eixo do apoio interno - Mac 
Os diagramas de força $x$ deformações nos pontos instrumentados estão mostrados nas figuras A.16 a A.33, conforme convenção apresentada na figura 4.28 do capítulo 4 .

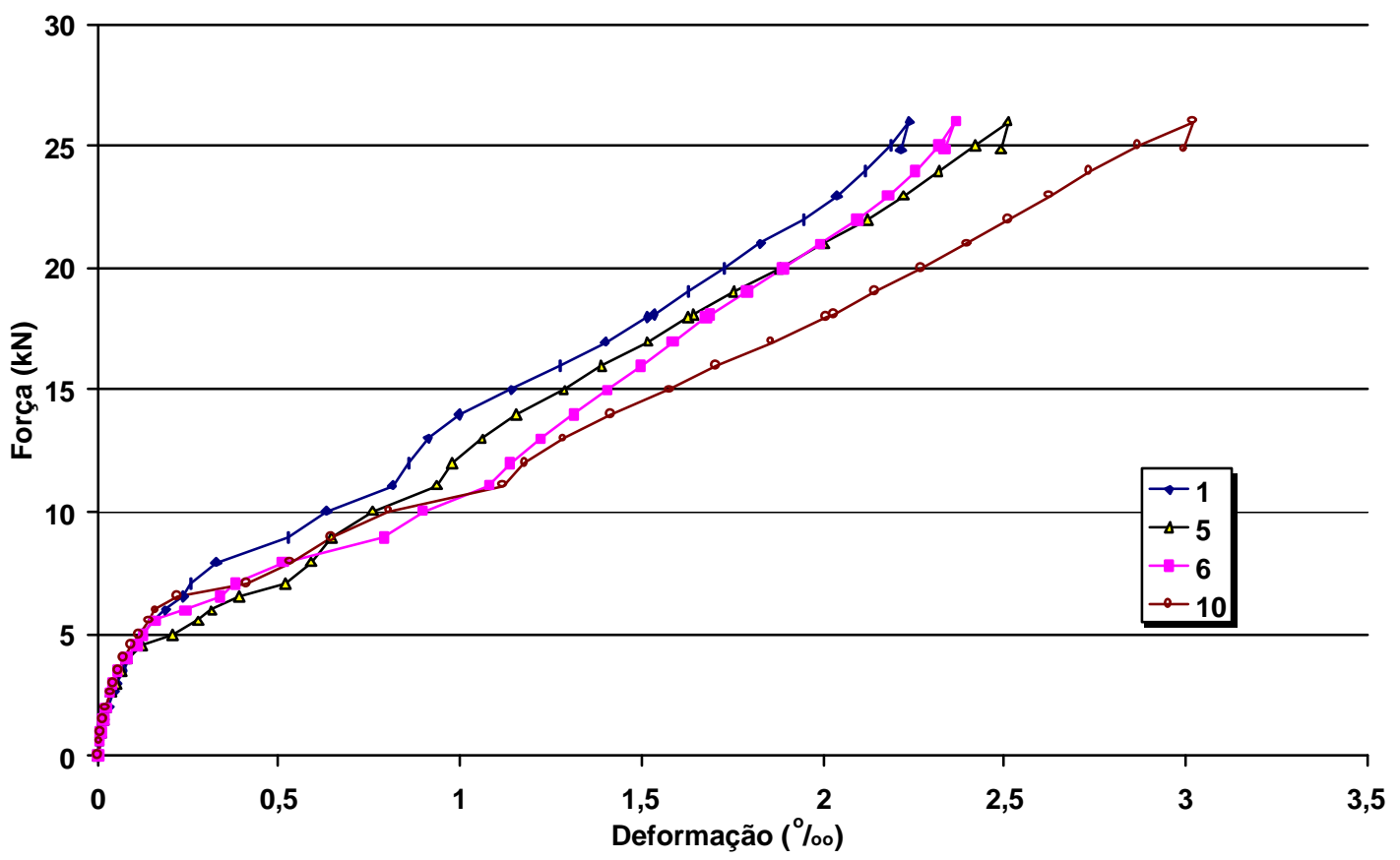

FIGURA A.16 - Deformações na armadura negativa nos pontos instrumentados a $25 \mathrm{~cm}$ do eixo do apoio interno - M15

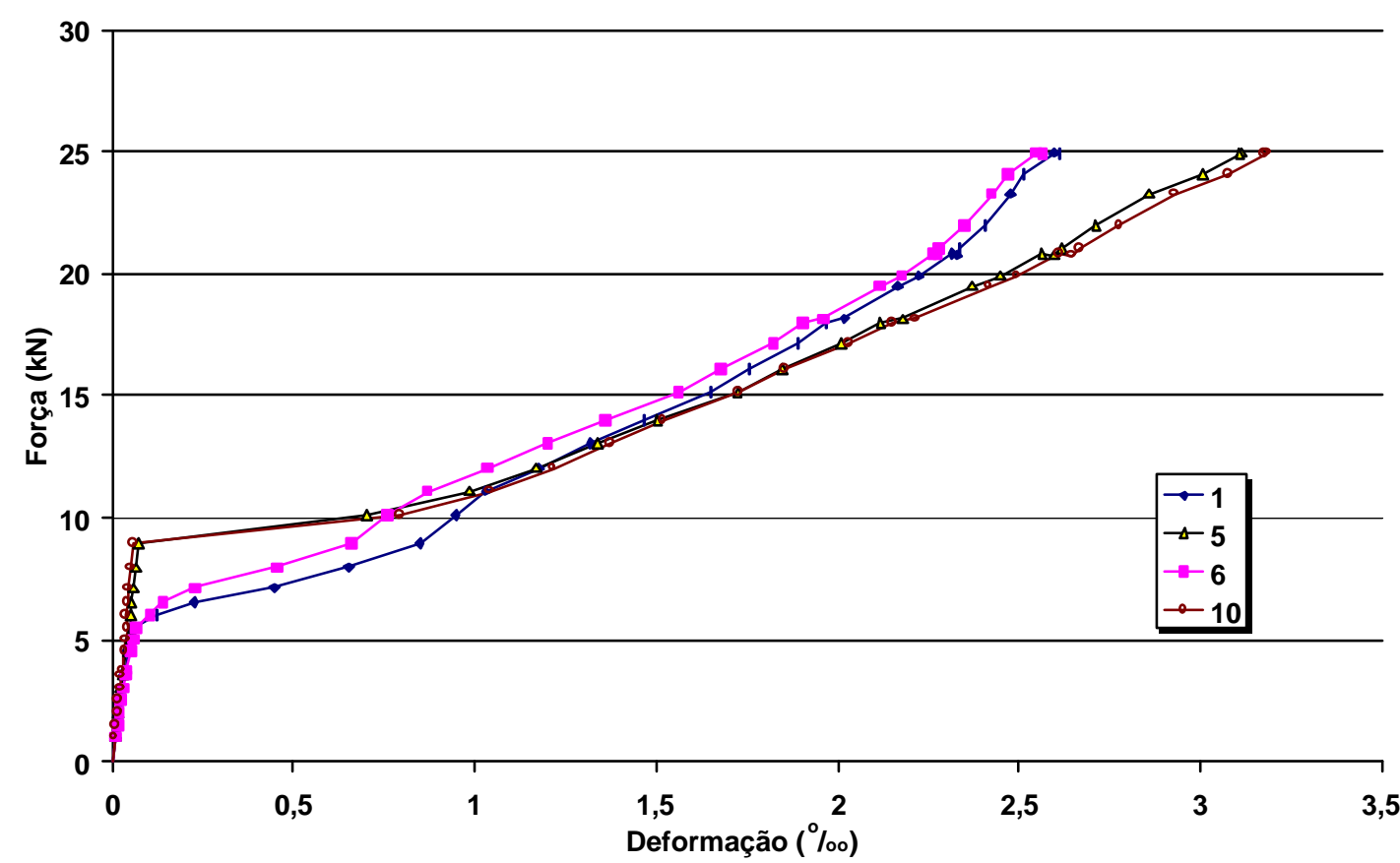

FIGURA A.17 - Deformações na armadura negativa nos pontos instrumentados a $25 \mathrm{~cm}$ do eixo do apoio interno - M40 


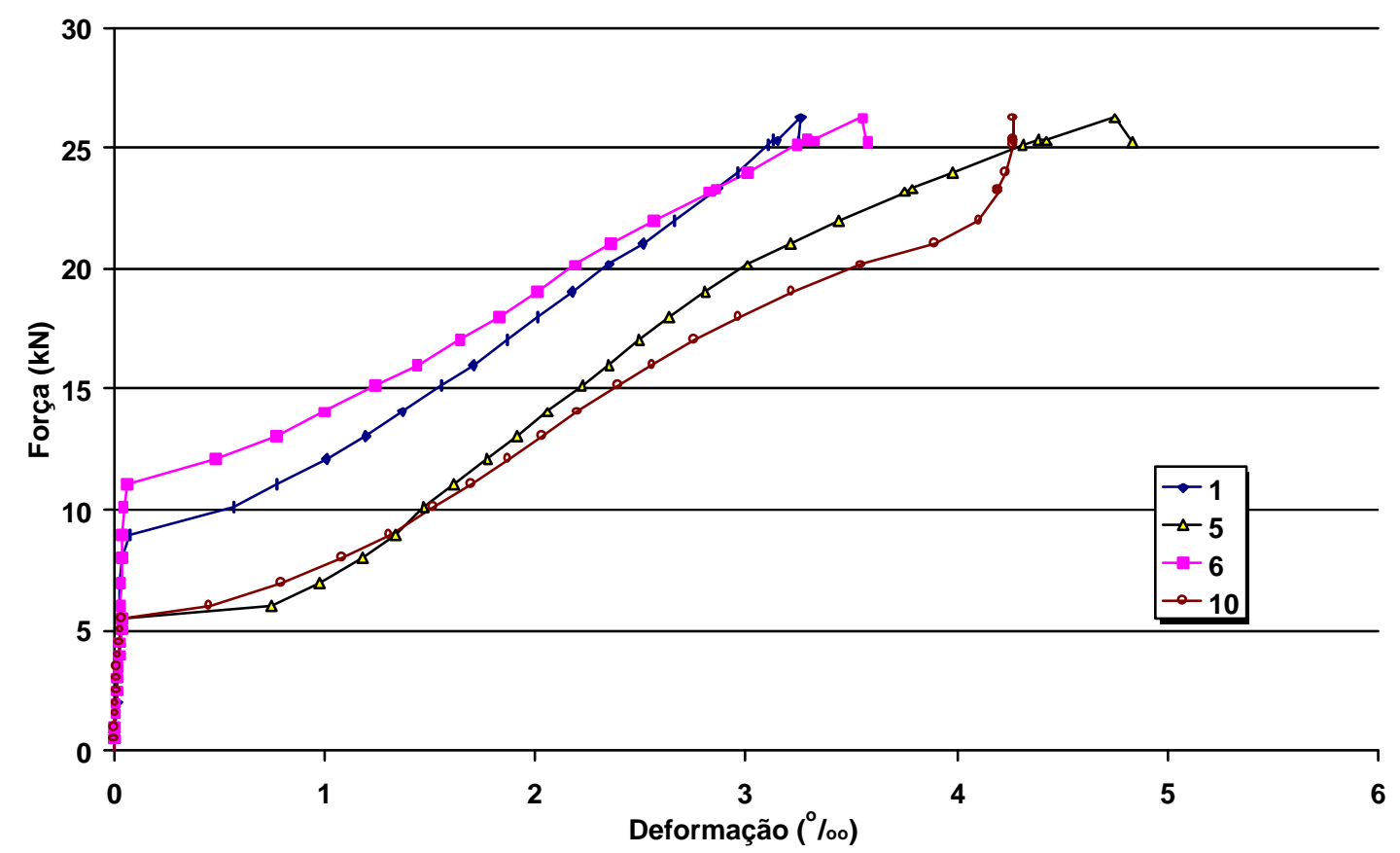

FIGURA A.18 - Deformações na armadura negativa nos pontos instrumentados a $25 \mathrm{~cm}$ do eixo do apoio interno - Mac

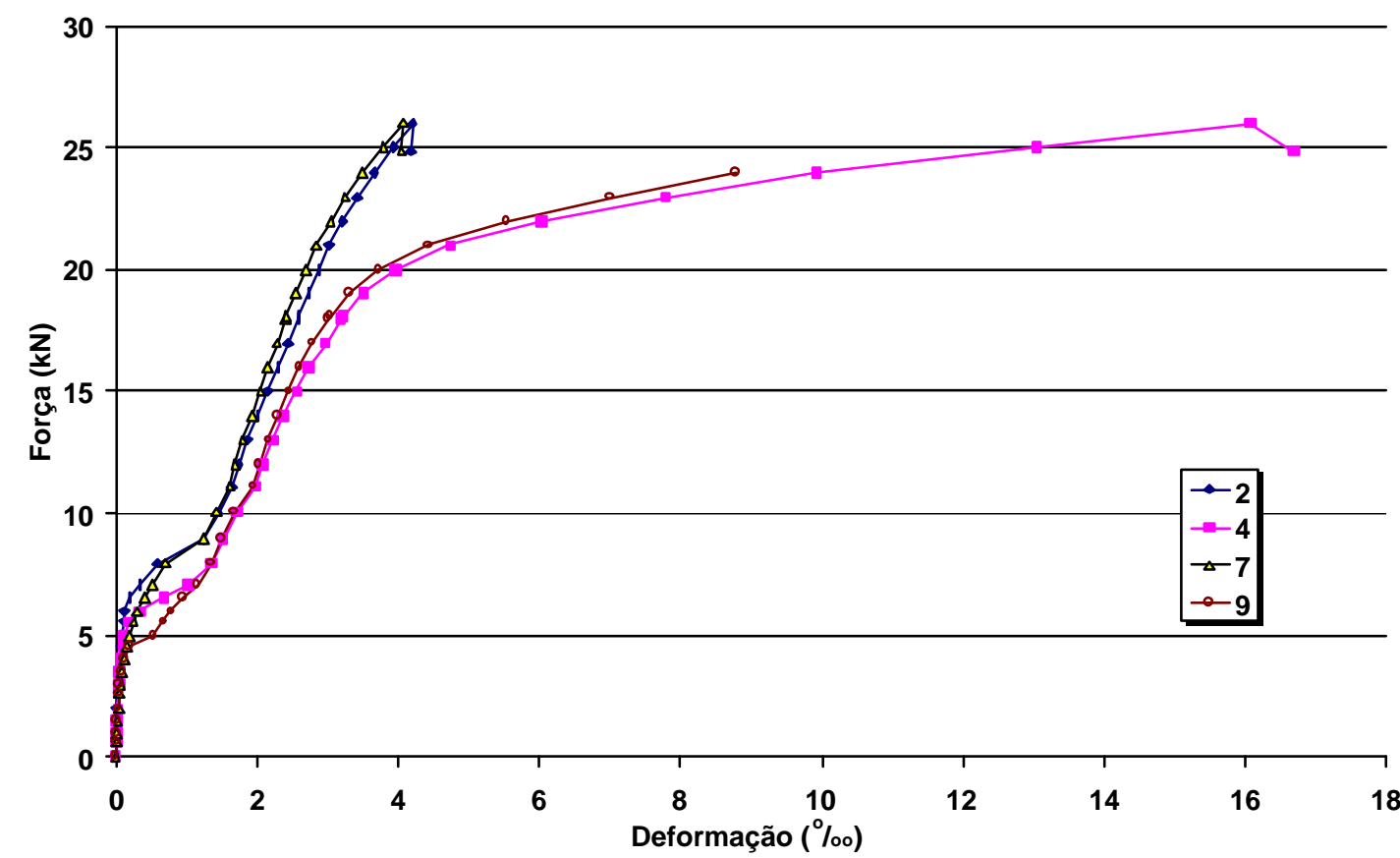

FIGURA A.19 - Deformações na armadura negativa nos pontos instrumentados a $10 \mathrm{~cm}$ do eixo do apoio interno - M15 


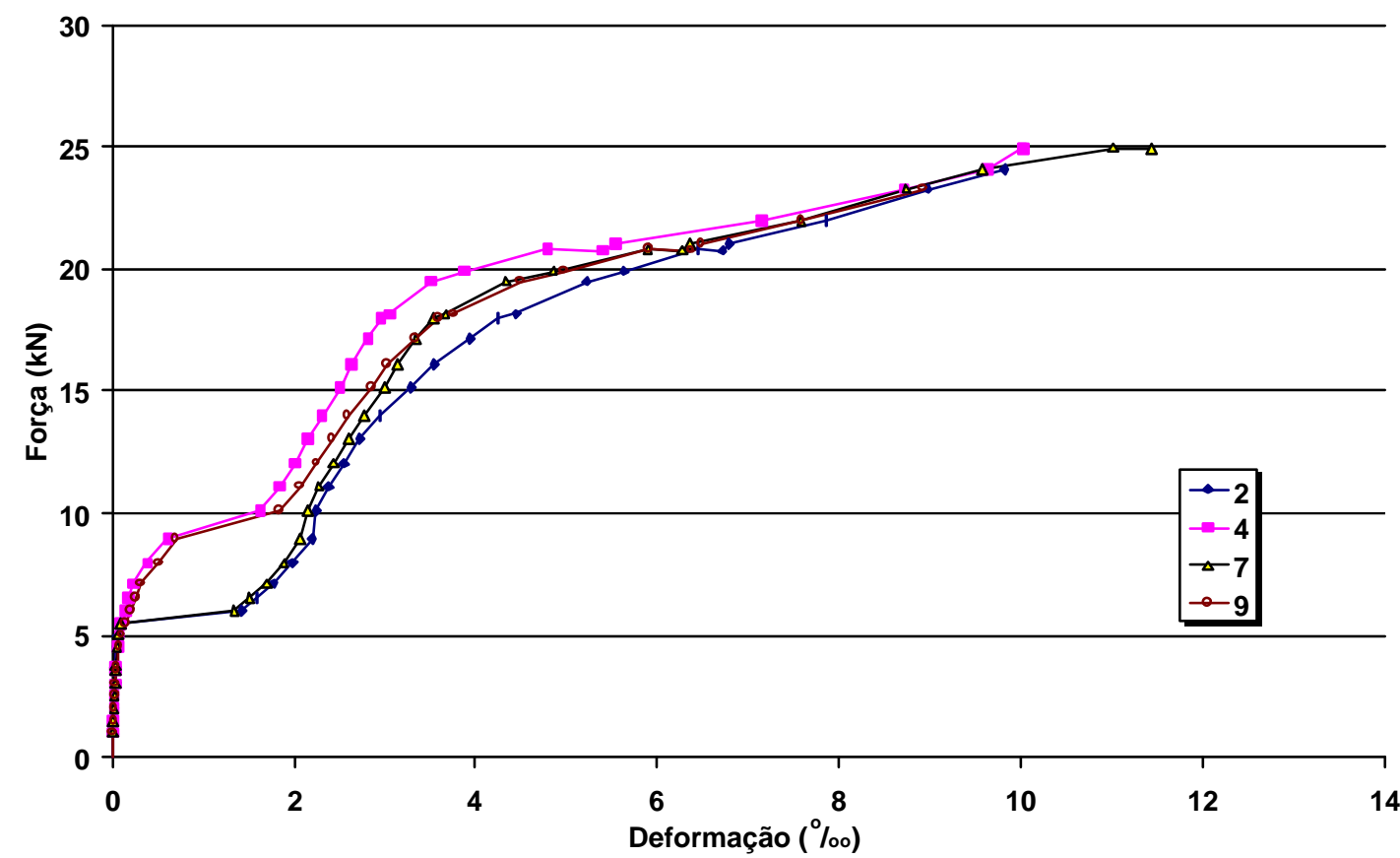

FIGURA A.20 - Deformações na armadura negativa nos pontos instrumentados a $10 \mathrm{~cm}$ do eixo do apoio interno - M40

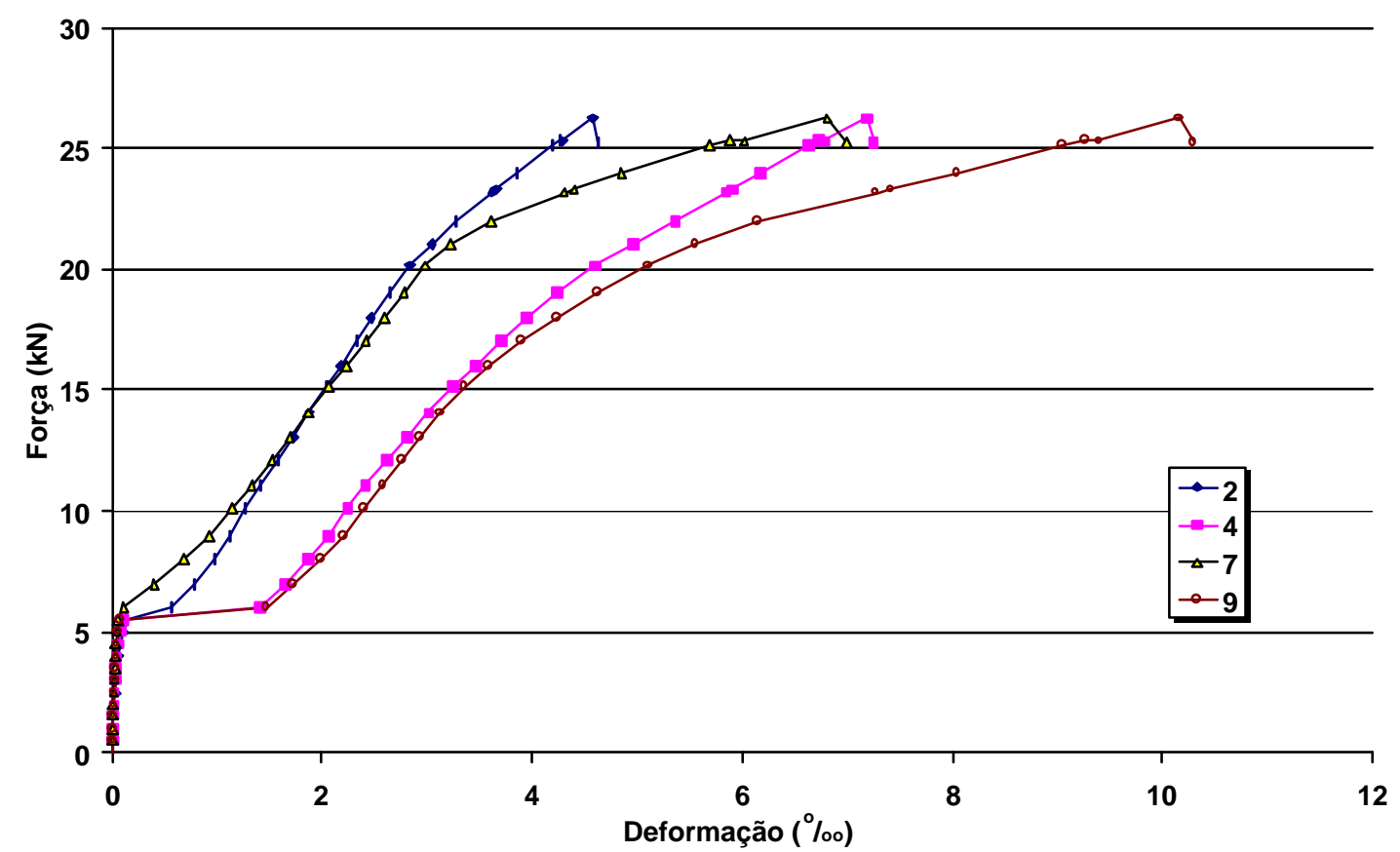

FIGURA A.21 - Deformações na armadura negativa nos pontos instrumentados a 10cm do eixo do apoio interno - Mac 


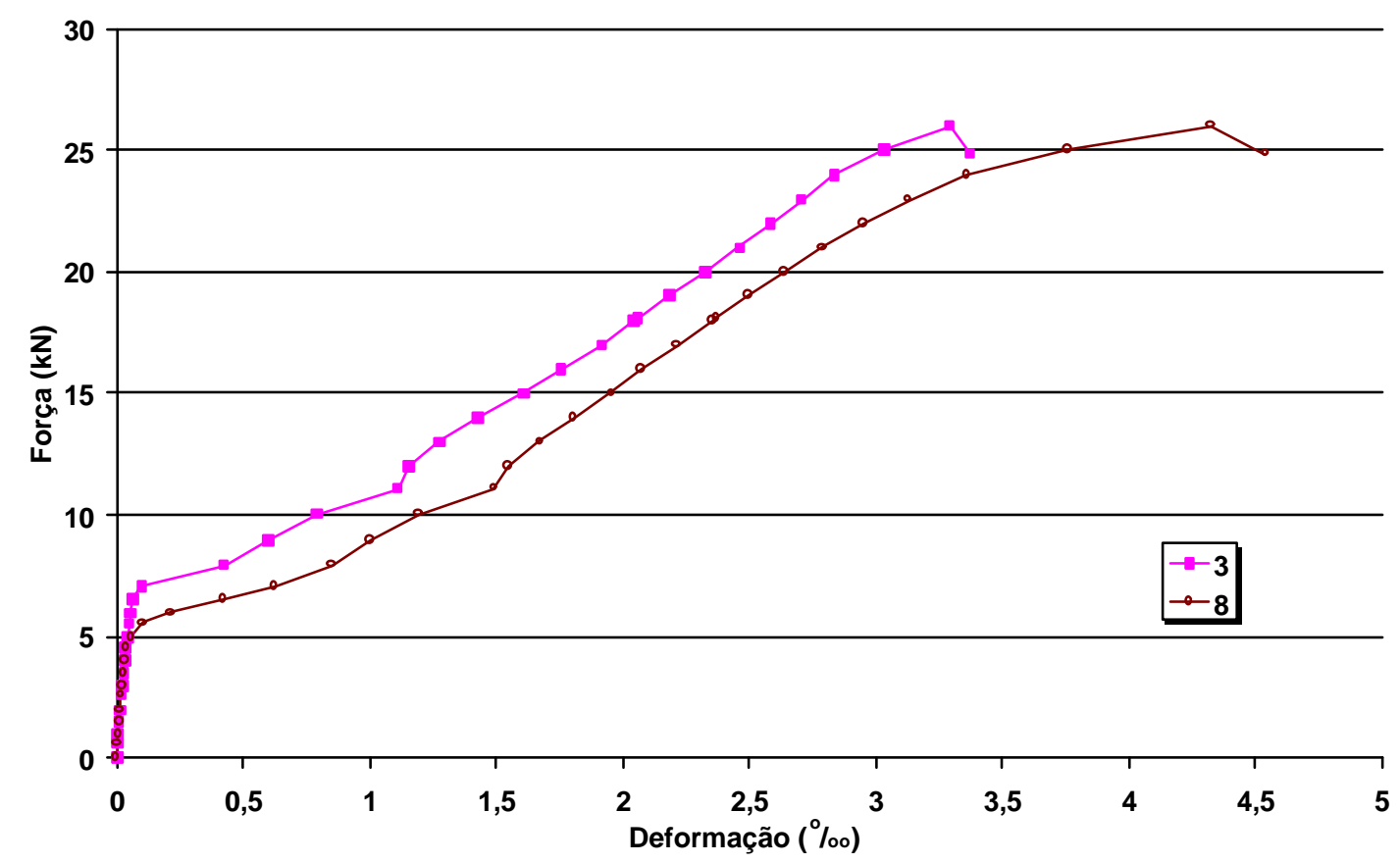

FIGURA A.22 - Deformações na armadura negativa nos pontos instrumentados no eixo do apoio interno - M15

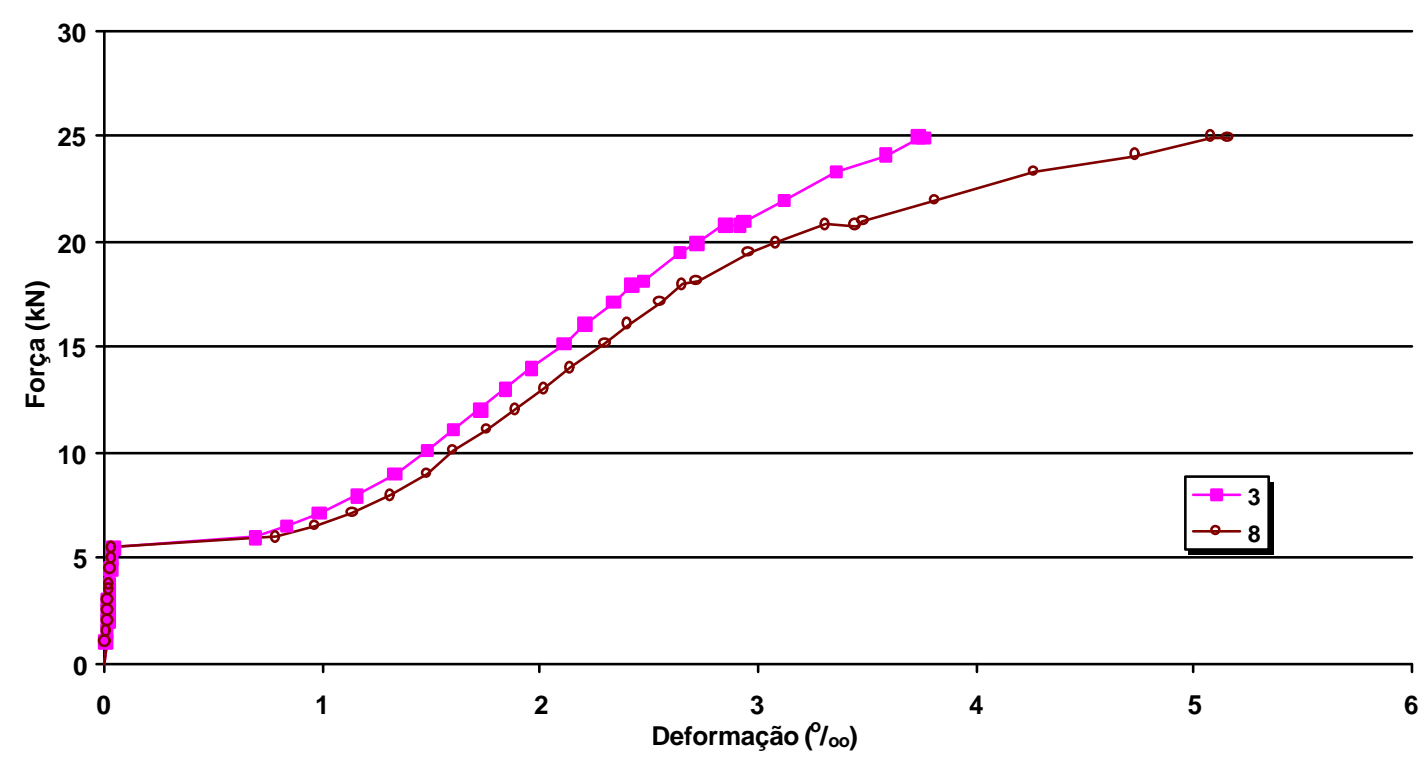

FIGURA A.23 - Deformações na armadura negativa nos pontos instrumentados no eixo do apoio interno - M40 


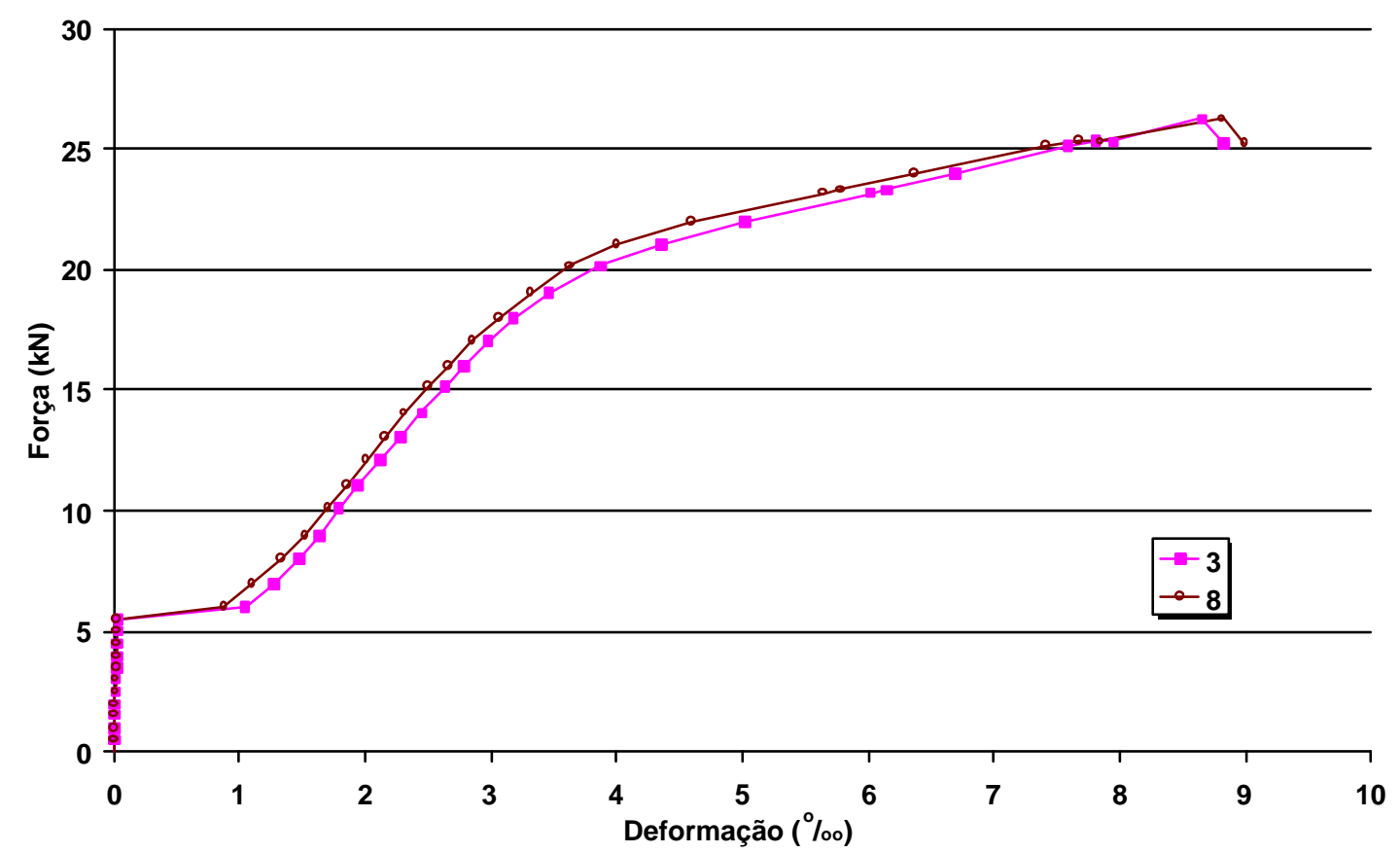

FIGURA A.24 - Deformações na armadura negativa nos pontos instrumentados no eixo do apoio interno - Mac

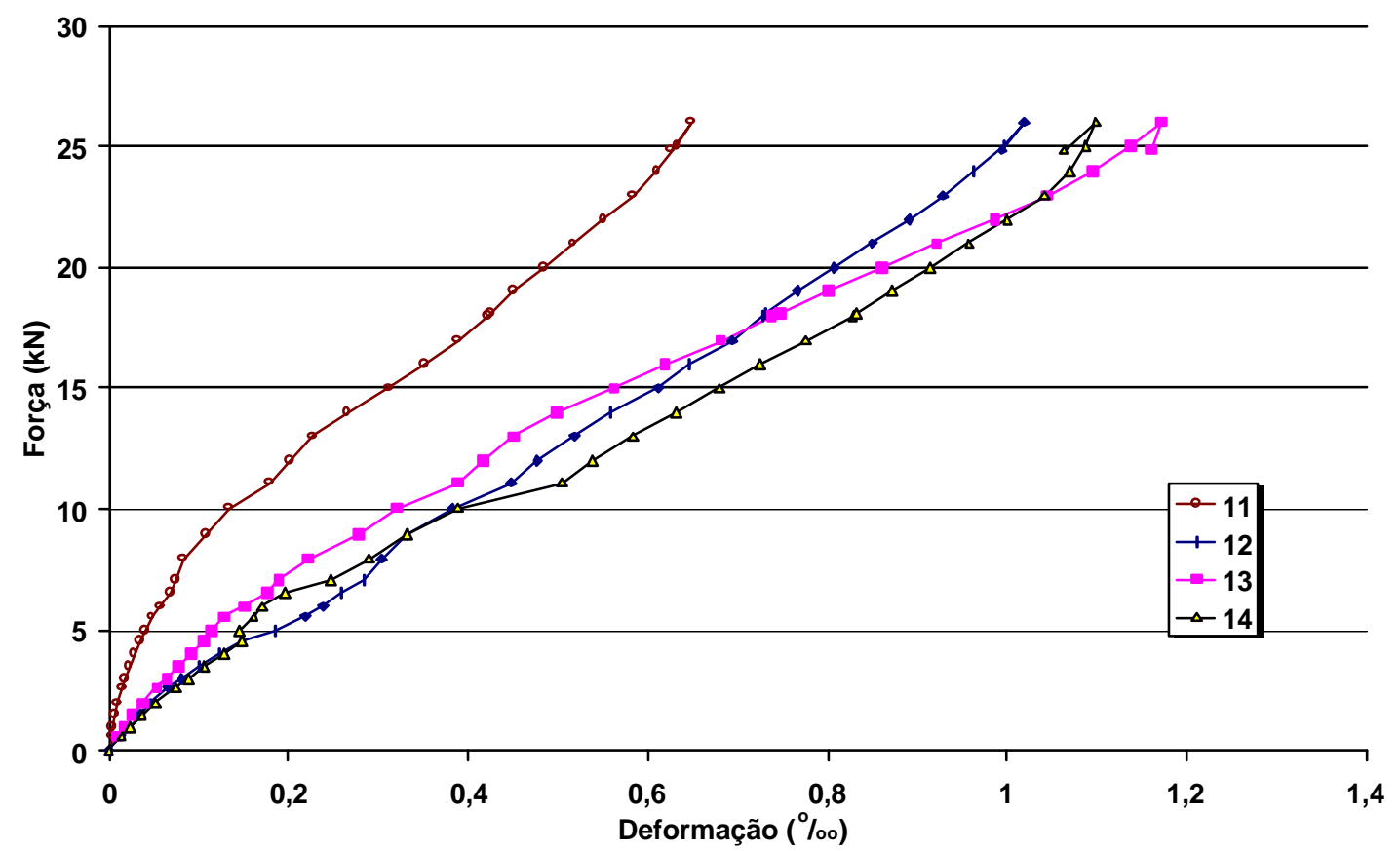

FIGURA A.25 - Deformações no concreto - M15 


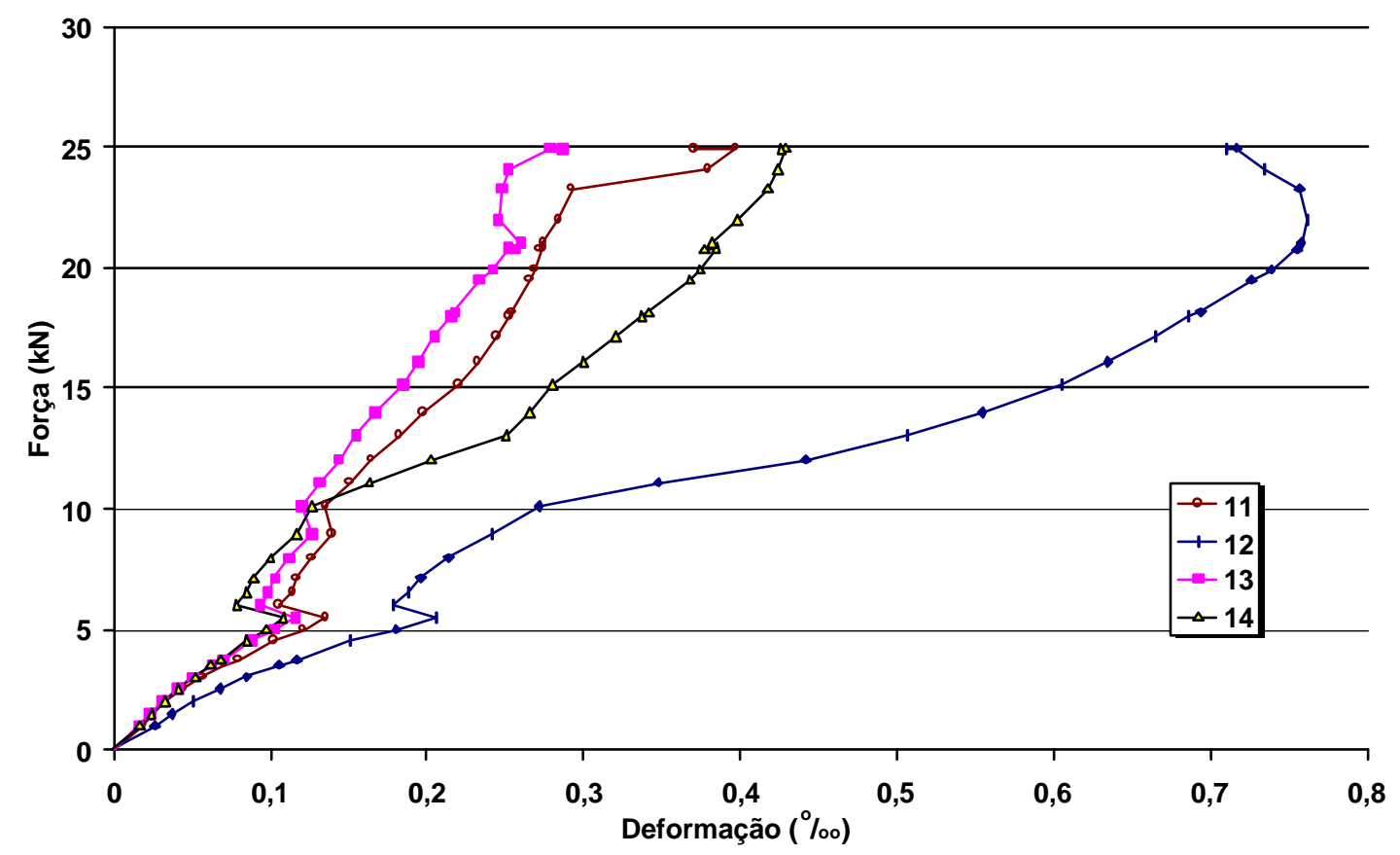

FIGURA A.26 - Deformações no concreto - M40

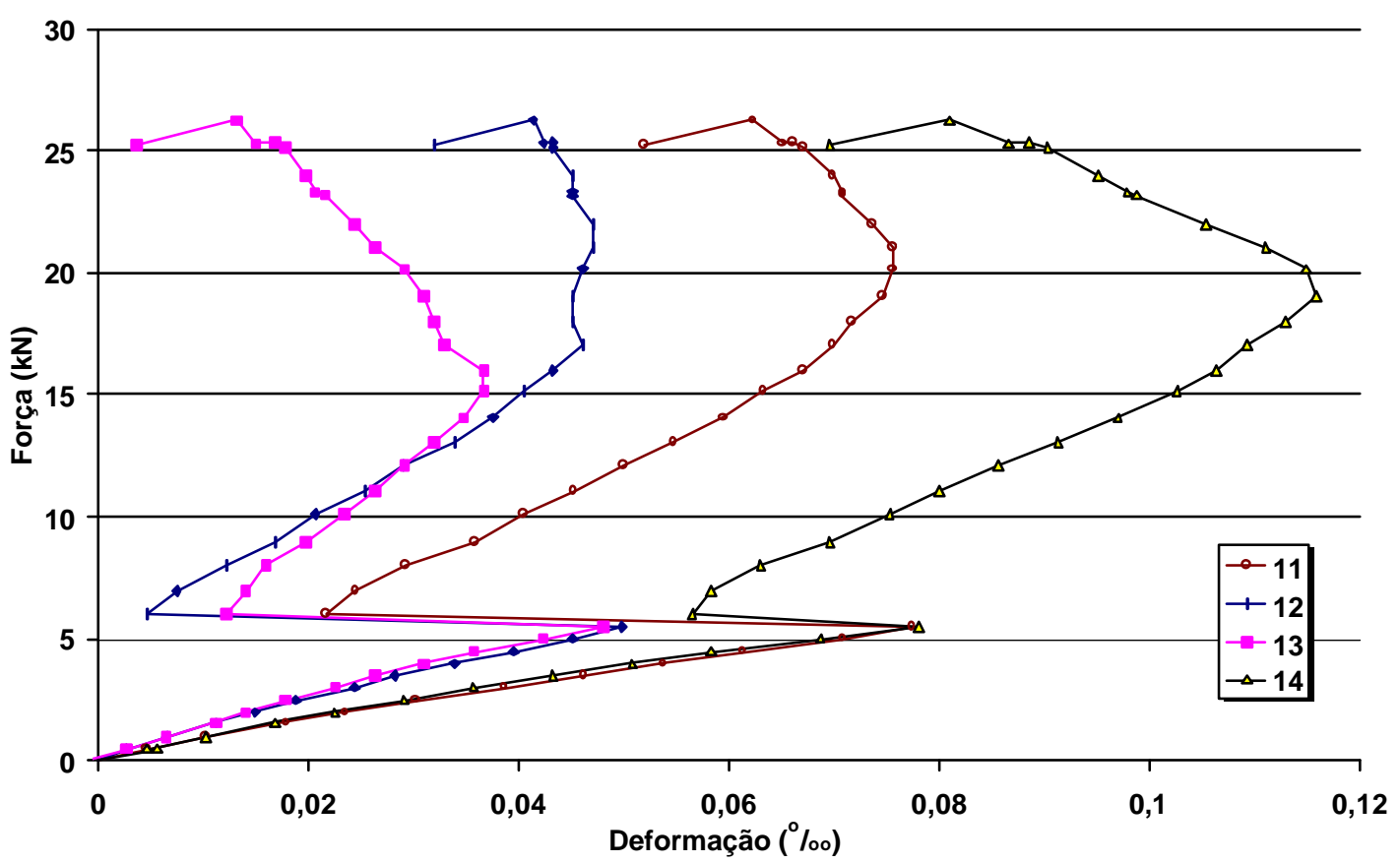

FIGURA A.27 - Deformações no concreto - Mac 


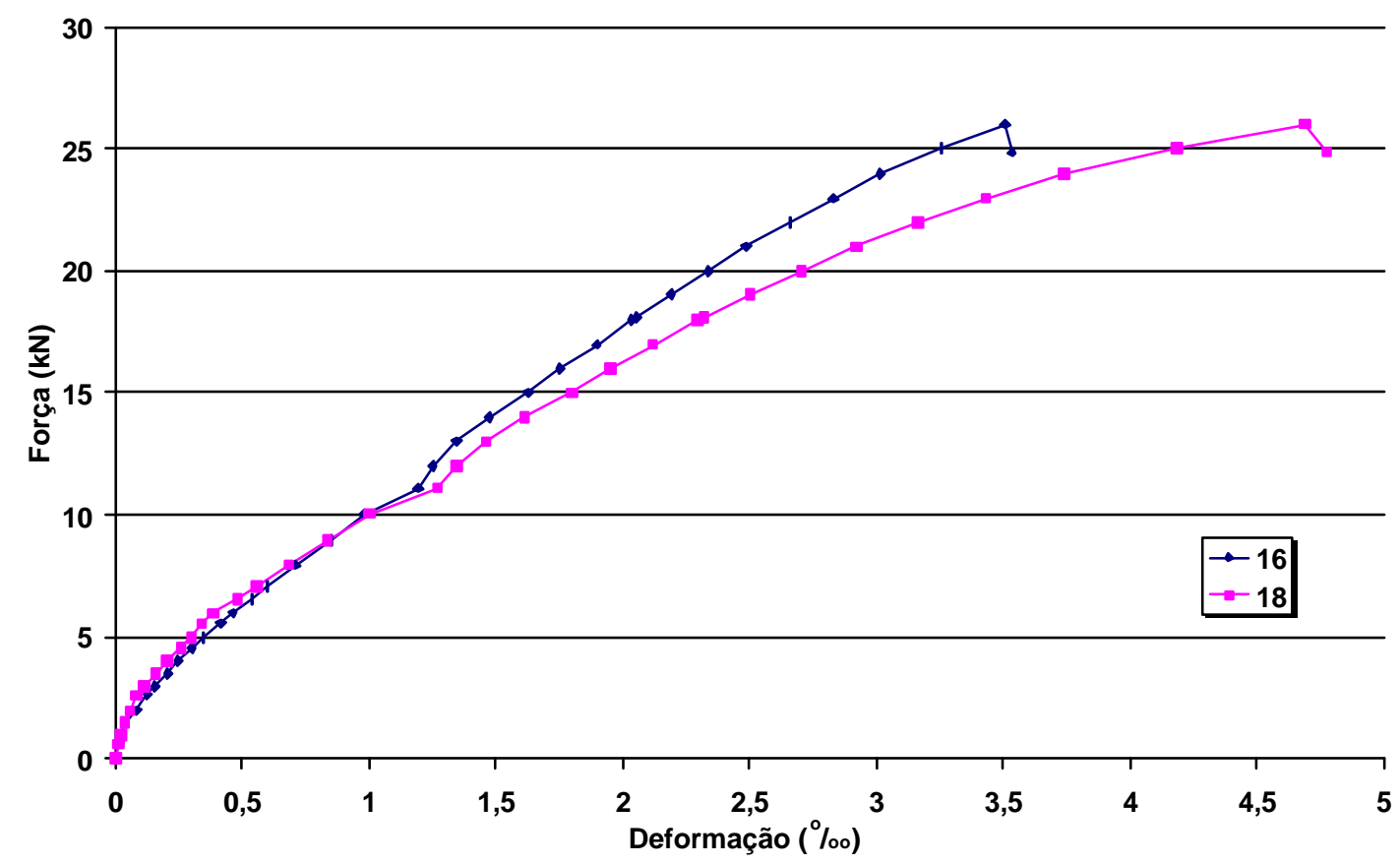

FIGURA A.28 - Deformações no fio do banzo inferior da armação treliçada - M15

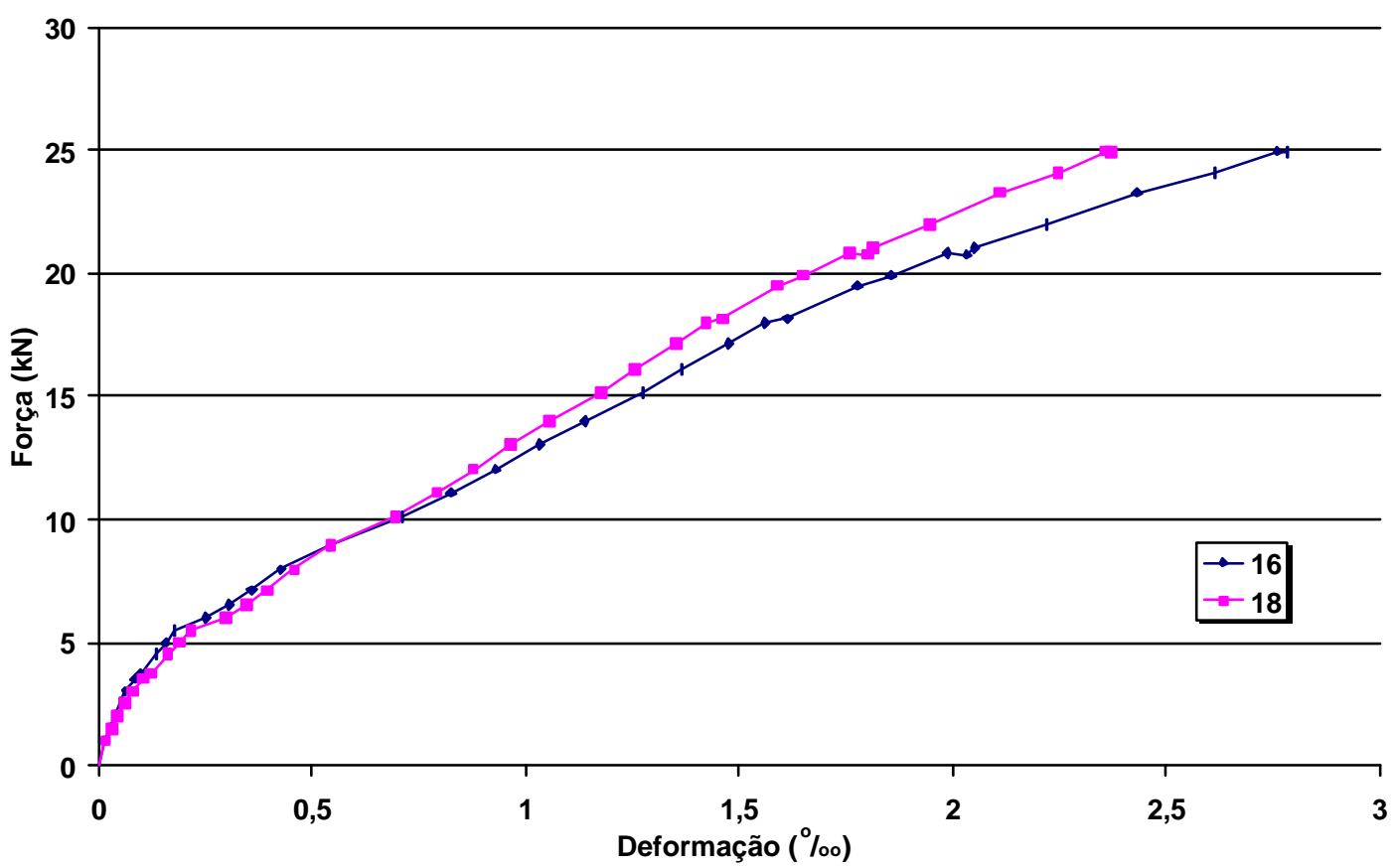

FIGURA A.29 - Deformações no fio do banzo inferior da armação treliçada - M40 


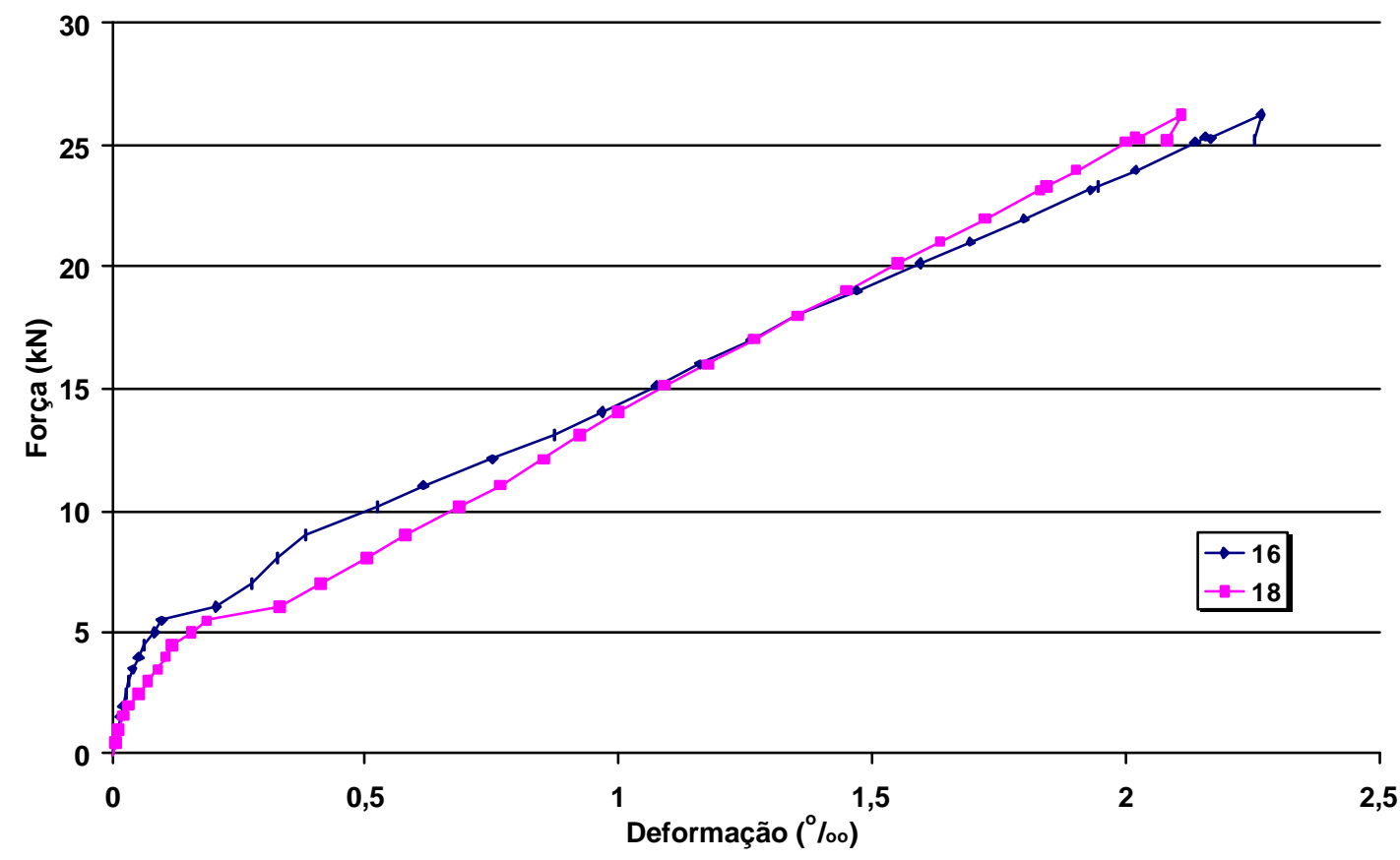

FIGURA A.30 - Deformações no fio do banzo inferior da armação treliçada - Mac

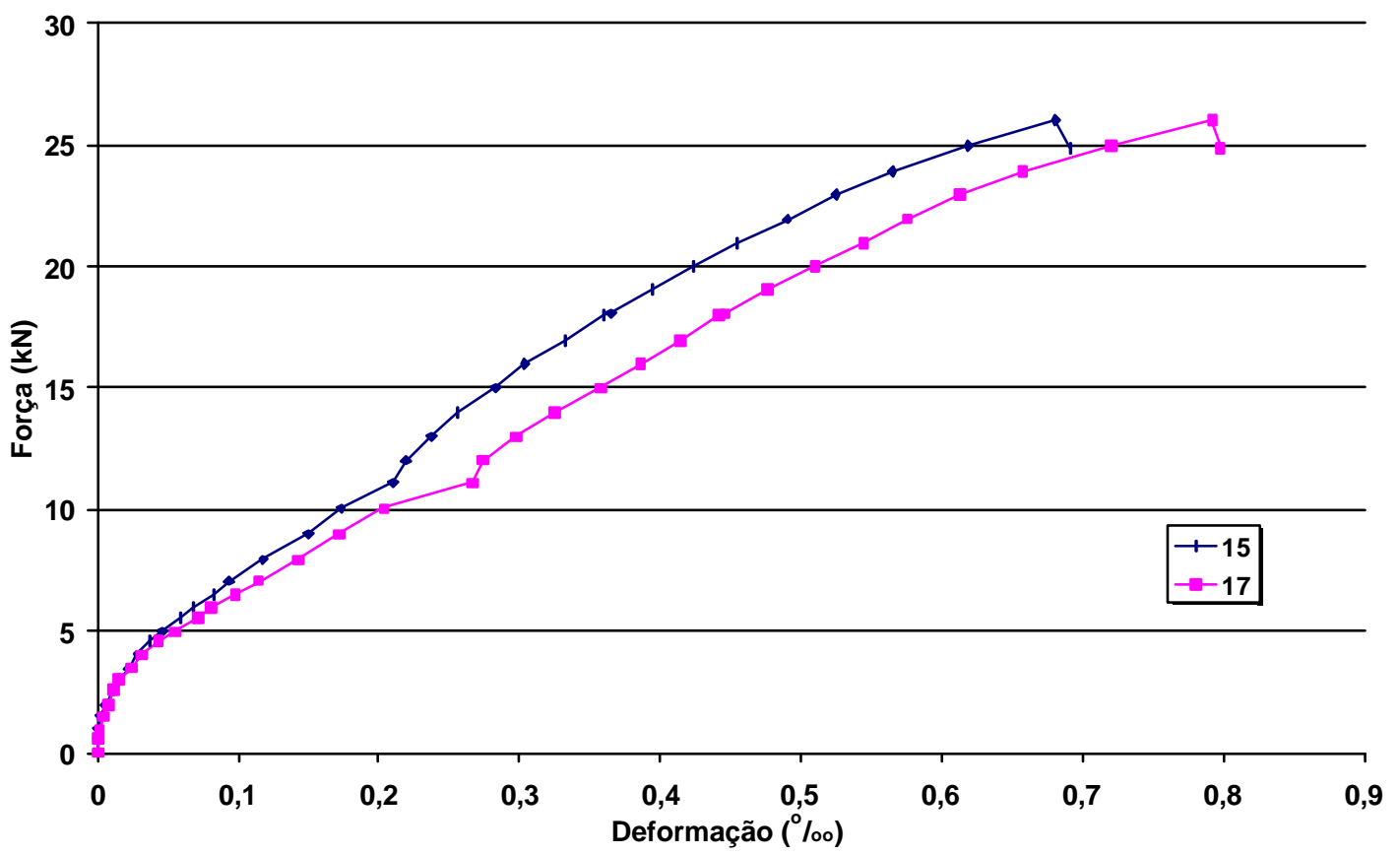

FIGURA A.31 - Deformações no fio do banzo superior da armação treliçada - M15 


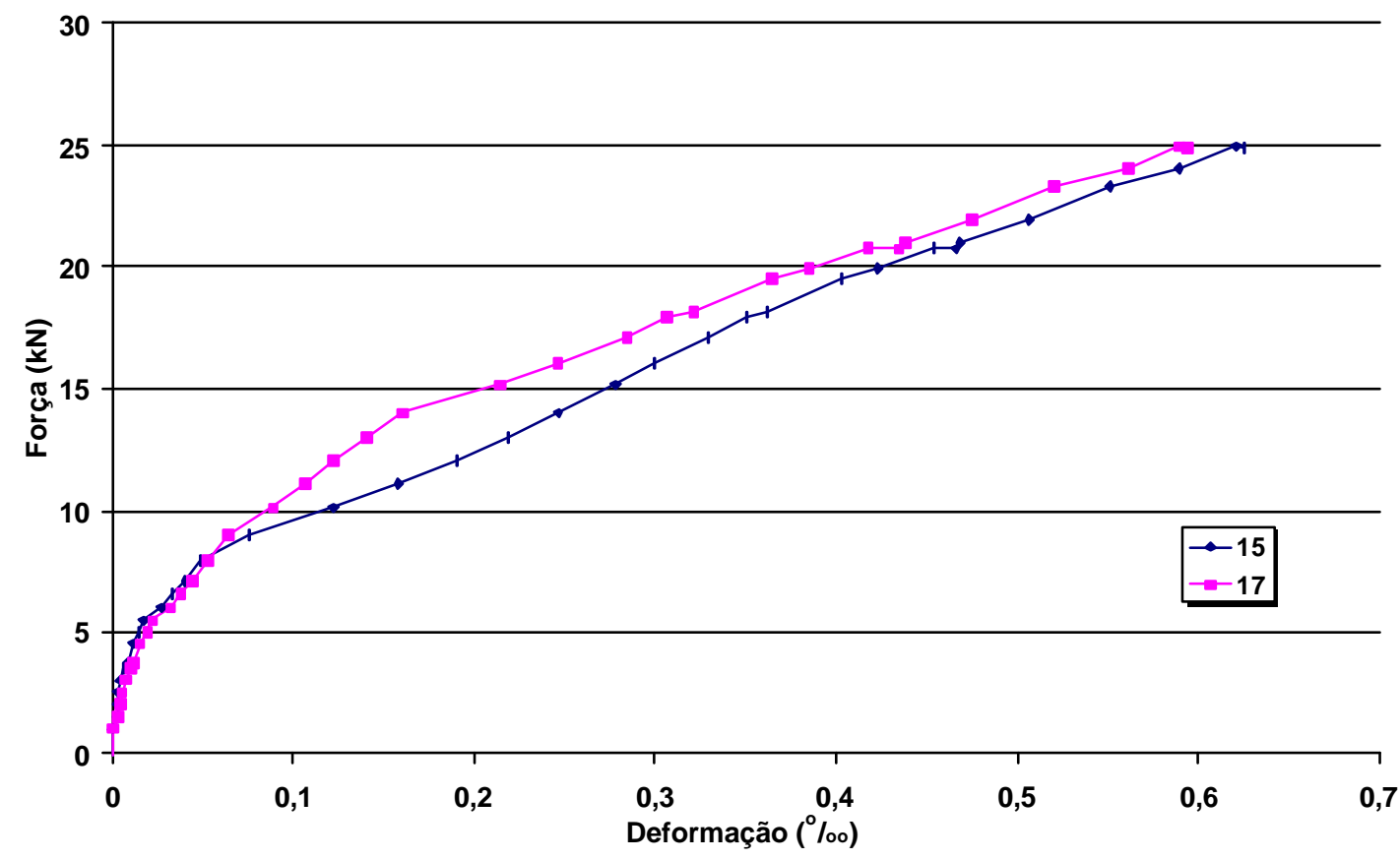

FIGURA A.32 - Deformações no fio do banzo superior da armação treliçada - M40

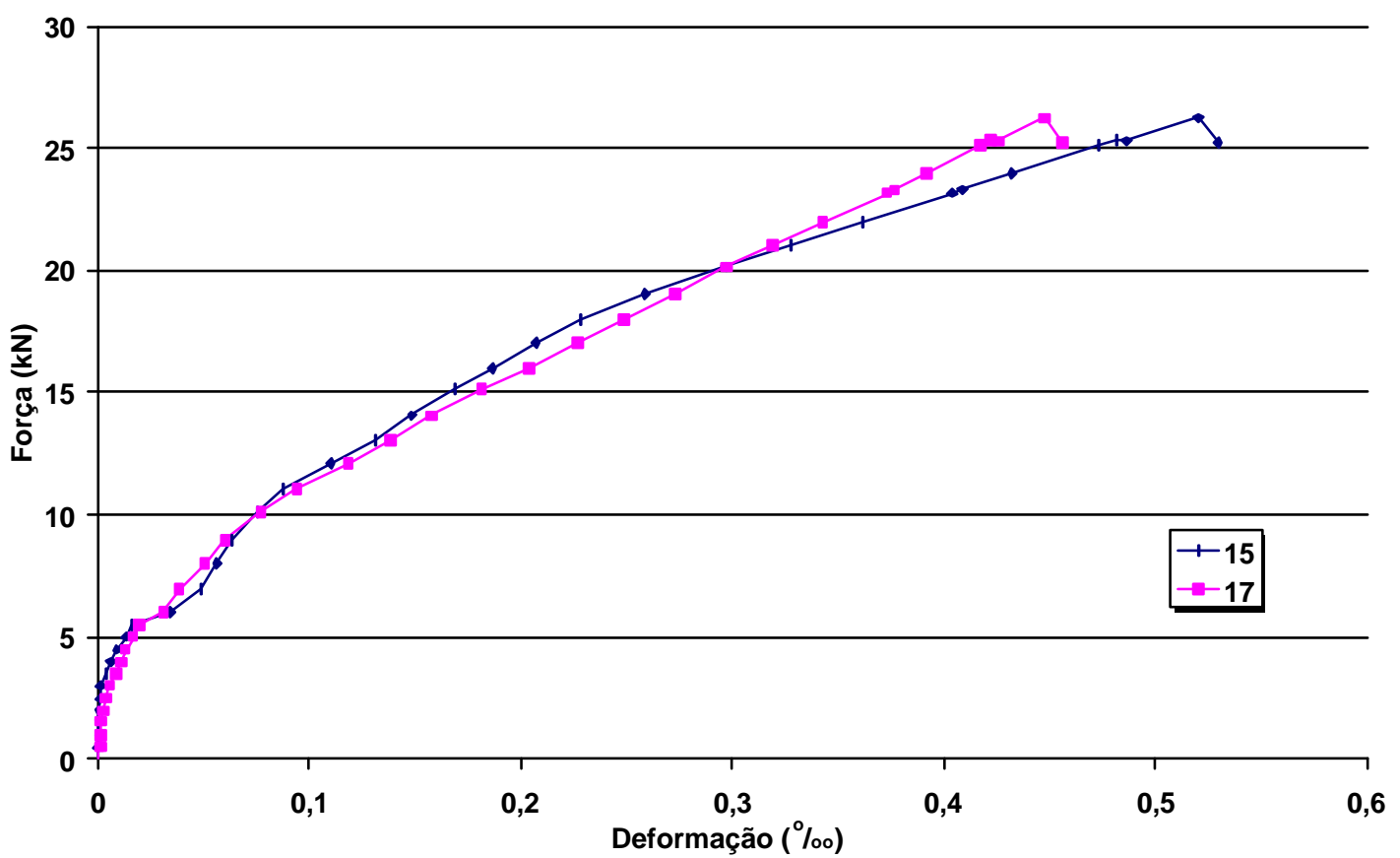

FIGURA A.33 - Deformações no fio do banzo superior da armação treliçada - Mac 